Danmarks Geologiske Undersøgelse.

II. Række. Nr. 58.

\title{
Kvartæret i Røgle Klint ved Lillebelt.
}

\author{
Af \\ Victor Madsen og V. Nordmann.
}

Résumé en français.

\author{
I Kommission hos \\ C. A. Reitzels Forlag \\ Axel Sandal \\ København \\ 1940.
}

Pris: $6 \mathrm{Kr}$. 
Danmarks Geologiske Undersøgelse.

II. Række. Nr. 58.

\title{
Kvartæret i Rogle Klint ved Lillebelt.
}

\author{
Af \\ Victor Madsen og V. Nordmann.
}

Résumé en français.

I Kommission hos

C. A. Reitzels Forlag

Axel Sandal

København

1940. 


\section{Indhold.}

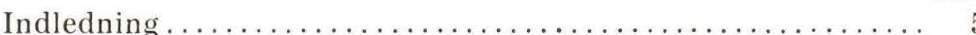

Udviklingen af Kendskabet til Røgle Klint............. 7

Aflejringerne i Røgle Klint....................... 23

1. Plastisk Ler.............................. 23

2. Glimmerler og Glimmersand $\ldots \ldots \ldots \ldots \ldots \ldots \ldots \ldots .23$

3. Moræne A............................... 24

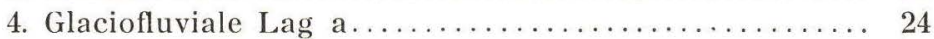

5. Tellinaleret.............................. 24

Tellinalerets Mollusker .................... 25

Tellinalerets Foraminiferer ................. 26

Tellinalerets Diatomeer.................... 27

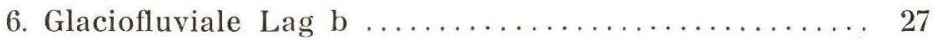

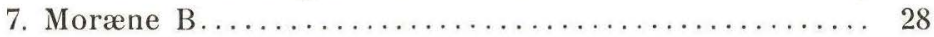

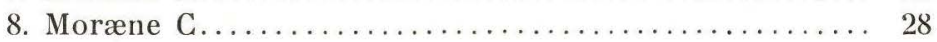

9. Glaciofluviale Lag c...................... 29

De glaciofluviale Lag e's Indhold af Skaller paa sekundært Leje ............................ 29

10. Moræne D . . . . . . . . . . . . . . . . . . . . . . 30

Bygningen af Røgle Klint ....................... 31

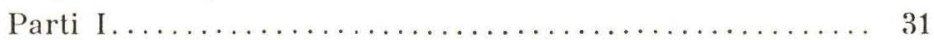

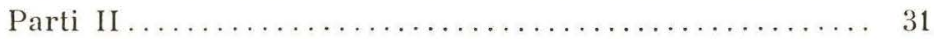

Parti III .................................... 35

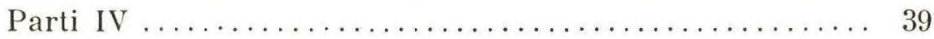

Parti V ................................. 41

Parti VI ..................................... 56

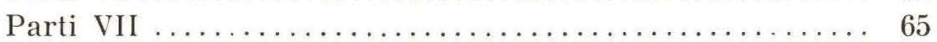

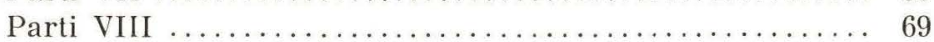

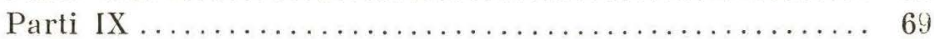

Oversigt ................................ 82

Slutningsbemarkninger $\ldots \ldots \ldots \ldots \ldots \ldots \ldots \ldots \ldots \ldots \ldots$

Dislokationernes og Lagenes Strygninger og Hældninger.... 88

Dislokationerne............................... 88

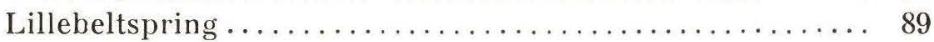

Lagene .................................. 90 


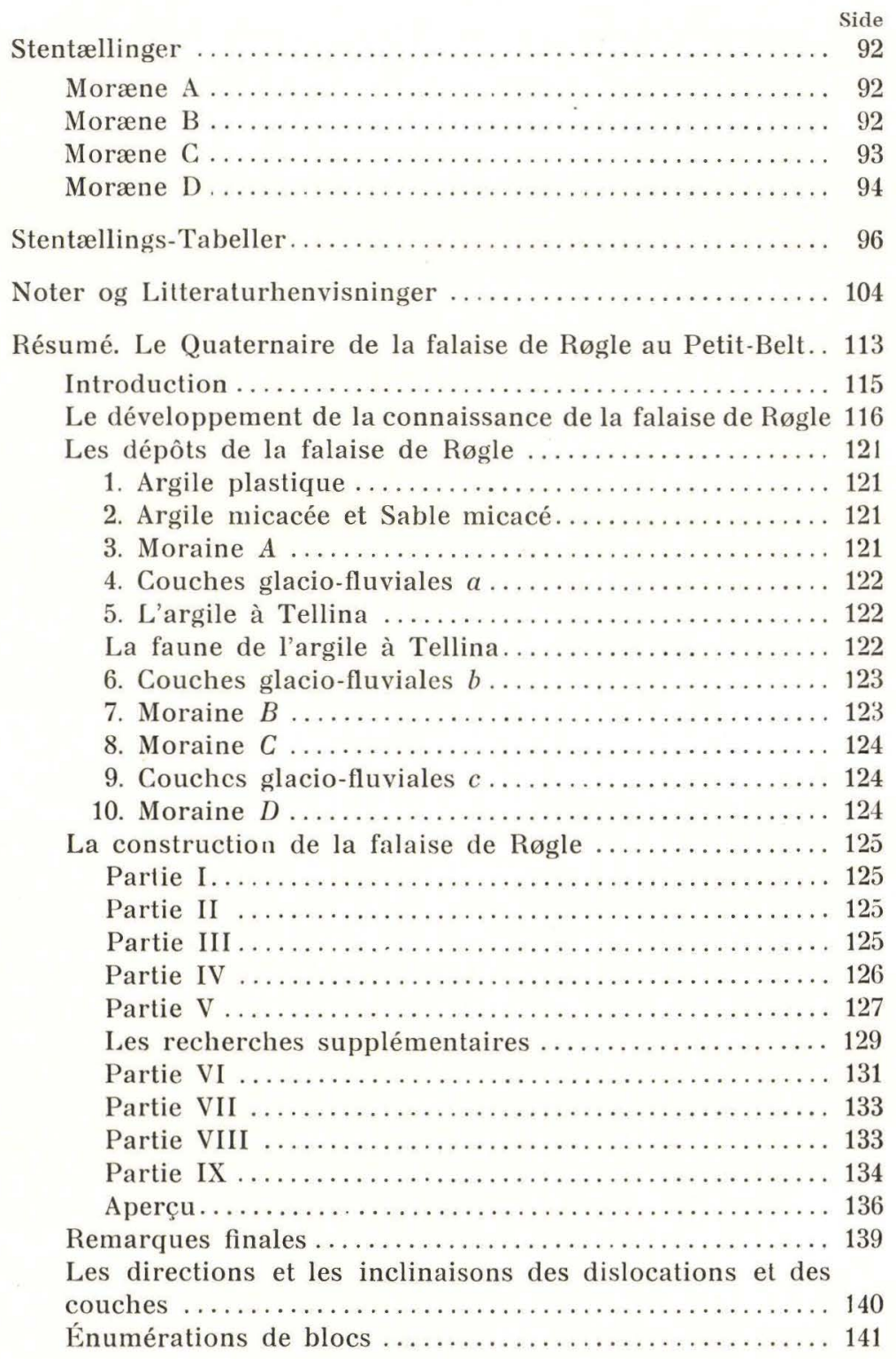




\section{Indledning.}

$\mathrm{N}$ aar man fra Strib følger Lillebelts Kyst mod Øst, kommer man først forbi en tilskreden og bevokset Klint, som hovedsagelig bestaar af Sand; derefter passerer man Røgle Mose, der er afspærret fra Havet ved en anselig Strandvold, dækket af Flyvesand, og man naar nu en Række Klinter, som følger Kysten paa den lille Halvø, der danner den nordvestligste Del af Fyn; de strækker sig ind i Baaring Vig til Fedet ud for Møllemade. Adskillige Steder staar disse Klinter saa rene, at deres Bygning ret nøje lader sig udforske. Paa den første Strækning, paa en Længde af lidt over 2 Kilometer, er de udelukkende dannede af kvartære Aflejringer. Derefter bestaar de for en stor Del af det eocæne Plastiske Ler. I dette Arbejde skal kun omhandles den første KlintStrækning fra Røgle Mose til den vestligste Forekomst af det Plastiske Ler i den saakaldte »Glimmerlerkløft«. Denne Klintstrækning benævnes i denne Afhandling »Røgle Klint $\left.\aleph^{1}\right)$.

For at lette Skildringen af de geologiske Forhold og Forstaaelsen af Klintens Bygning har vi delt den i 9 Partier, som vi har betegnet med Tallene I-IX regnede fra Sydvest, fra Røgle Mose. P a r ti I har en Længde af $375 \mathrm{~m}$; Parti I omfatter Klintens saakaldte "Sandprofil". P a r t i I har en Længde af $850 \mathrm{~m}$ og naar til $1225 \mathrm{~m}$ fra Klintens Vestende; det danner det følgende, uforstyrrede, helt bevoksede Parti af Klinten. Parti I I har en Længde af $170 \mathrm{~m}$ og naar til $1395 \mathrm{~m}$ fra Klintens Vestende; i dette begynder Forstyrrelserne i Klintens Lagfølge. Parti IV har en Længde af $80 \mathrm{~m}$ og naar til $1475 \mathrm{~m}$ fra Klintens Vestende, til det dybeste Sted i Dalen, som fra Kysten gaar ind imod Gaarden Christiansminde. P a r i V har en Længde af $190 \mathrm{~m}$ og naar til $1665 \mathrm{~m}$ fra Klintens Vestende, til et ikke videre udpræget Fremspring af Klinten, som vi ved vore Undersøgelser har benæunt Nr. 11. Parti V I har en Længde af $120 \mathrm{~m}$ og naar til $1785 \mathrm{~m}$ fra Klintens Vestende; Klinten danner i dette Parti 2 Fald og 2 Næser (Fremspring), som vi ved vore Undersøgelser har benævnt Nr. 13 (her forandrer Kysten Retning fra SV.-NØ. til V.-Ø.) og Nr. 17, Partiets Østgrænse. Parti V I har en Længde af $65 \mathrm{~m}$ og naar til $1850 \mathrm{~m}$ fra Klintens Vestende; Klinten danner her et Fald, begrænset af 2 Næser Nr. 17 og Nr. 20, Partiets Østgrænse. P a rti VIII har en Længde af $60 \mathrm{~m} \mathrm{og}$ naar til $1910 \mathrm{~m}$ fra Klintens Vestende, til Næse Nr. 21. Der findes i det en kratbevokset Kløft, som fortsætter sig et Stykke ind i Landet; Klinten danner her et stort Skred, som naar ind til Gaarden 
Sølysts Have. Parti IX har en Længde af $130 \mathrm{~m}$ og naar fra Næse Nr. 21 til $2040 \mathrm{~m}$ fra Klintens Vestende til den saakaldte "Glimmerlerkløft", hvor Tertiæret begynder. Lagene i dette Parti staar omtrent lodret.

Hvor intet andet er bemærket, er Billederne i det følgende fotograferede af Victor Madsen.

Naar man vil besøge Røgle Klint, kan man tage med Rutebil fra Middelfart til Strib og gaa til Fods videre langs med Kysten over Strandvolden ved Røgle Mose til Klintens Vestende med »Sandprofilet« og fortsætte langs med Klinten. Men man kan ogsaa i Stedet for straks at gaa langs med Klinten følge Vejen fra Røgle Mose forbi Gaardene Provsteskovlund, Søborg og Marielyst til Villaerne paa Klinten Øst for Sølyst, hvor man ad en Sti kan komme ned paa Stranden over det Plastiske Ler lidt Øst for »Glimmerlerkløften", og gaa paa Stranden langs med Klinten tilbage til Strib. Ved Røgle Klints Vestende er der et Traktørsted »Klinten« med en smuk Udsigt. Der kan man faa en Forfriskning.

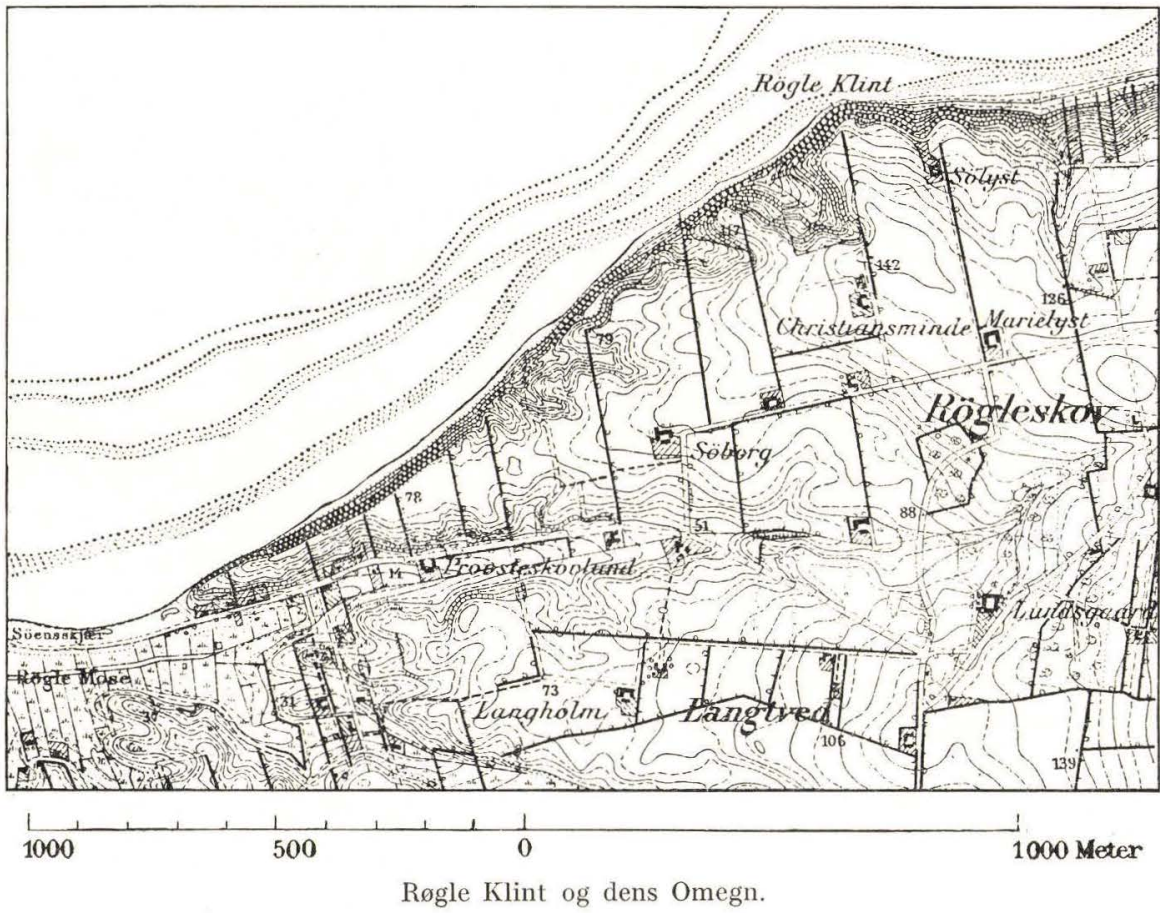

Autoriseret Reproduktion efter Geodætisk Instituts Maalebordsblad i 1:20000 Nr. 3312 Katrinebjerg, 1929. Højdeforskellen mellem Kurverne er paa Landjorden 5 Fod, i Havet

6 Fod. Højdetallene er i Fod $(1$ Fod $=0,314 \mathrm{~m})$.

La falaise de Røgle et ses environs.

Reproduction autorisée d'après la carte de l'Institut géodésique, à l'échelle de 1:20 000, no. 3312 Katrinebjerg, 1929. La différence de niveau entre les courbes est, sur la terre ferme, de 5 pieds, et dans la mer, 6 pieds. Les cotes sont indiquées en pieds.

$(1$ pied $=0,314 \mathrm{~m})$. 


\section{Udviklingen af Kendskabet til Røgle Klint.}

D e ejendommelige Jordarter, som forekommer i Omegnen af Røgle Klint, tiltrak sig allerede i det 18. Aarh. Opmærksomheden. Der er bevaret et Uddrag af en Skrivelse af 11. Okt. 1735 fra Grev Stollberg til Kong Christian VI, hvori Greven meddeler Kongen, at der paa Kysten ved Billeshave (1800 m Syd for Røgle Klint) findes en sort Jordart, som ser ud til at være guldholdig; endvidere er der Svovlkies, Terra sigillata (Plastisk Ler), som kan anvendes til Statuer, og Blaaler, hvoraf der kan laves Lervarer. Han foreslaar Kongen at købe Stedet og anlægge en Fabrik. Uddraget af Grevens Skrivelse blev af Kongen med en egenhændig Skrivelse sendt til Grev Frederik Danneskjold Samsøe, i hvis Arkiv den fandtes. Yderligere fandtes der et Uddrag, skrevet med Kongens Haand, af en Skrivelse af 10. Febr. 1736 fra Grev Stollberg. Han har ladet den sorte Jord undersøge med det Resultat, at $50 \mathrm{~kg}$ indeholder en Guldmængde svarende til $11_{2}^{1 / 2}$ Dukat (c. $5 \mathrm{~g}$ ) $\mathrm{og}$ saaledes er for fattig til at kunne udnyttes. $50 \mathrm{~kg}$ Svovlkies indeholder $47 \mathrm{~g}$ Sølv, som det altsaa kan lønne sig at udvinde, naar der er samlet tilstrækkelig meget Svovlkies. Den røde Jord er meget $\left.\operatorname{god}^{2}\right)$.

Det Plastiske Ler ved Billeshave omtales af Pontoppidan i hans Danske Atlas $^{3}$ ). Han siger om dette: »Bolus tienlig til adskilligt Brug og af adskillig Farve findes rød ved Fridericia i Jylland, saa og lige over for, paa den anden Side af det lille Belt, ved Herregaarden Billeshauge i Fyen.«

Røgle Klint blev undersøgt af Forchнамmer 1840. Den Gang medregnede han endnu vort Tertiær til »Rullestensformationen", som han inddelte i: 1) Rav-Brunkulformationen, 2) Rullestensleret og 3) Rullestenssandet. Rav-Brunkulformationen ansaa han for at være af ældre pliocæn Alder, Rullestensleret for yngre pliocænt, og Rullestenssandets Dannelse "naar dybt ind i den nuværende Jordperiode."

Forchнамmer var af den Anskuelse, at i »Rullestensformationen"s Tid havde Jordens indre Kræfter i høj Grad været i Virksomhed. Jordskorpens Lag var blevet stærkt forstyrrede ved de underjordiske Dam- 
pes Tryk, - man træffer jo hyppigt i vore Klinter meget forstyrrede Lag, - Dampene havde af Grundfjældet i Dybet dannet Ler, Rullestensleret, der var brudt frem, medrivende Stumper af Grundfjældet og de overliggende Formationer, Stenene i Rullestensleret. Dette skulde være foregaaet paa Havets Bund, — man finder jo i »Rullestensformationen« Skaller af Havdyr i Glimmerleret, i Cyprinaleret (som regnedes til Rullestensleret) og i Tarbeck-Skalgruset (som regnedes til Rullestenssandet).

Forсннамmer sluttede af de foreliggende Kendsgerninger ${ }^{4}$ ), "at der i Rav-Bruunkulformationens Tid har fundet en forholdsviis roligere Udvikling Sted, der alligevel hyppigen var afbrudt ved Bevægelser, der have bragt skandinaviske Rullestene ned i Havet, uden at selve Havets Bund er bleven opbrudt. I Rullesteensleerformationens Tid har Forstyrrelsen naaet den høieste Grad; Masser af Rullestene ere førte ned fra den skandinaviske Halvøe og Havets Bund er overalt brudt op ved underjordiske Kræfter, og har derved leveret Materialet til Mergellagene. I begge disse Formationer synes Bevægelsen at være gaaet ud fra den skandinaviske Halvøe og dens Retning at have været fra Nord og Øst; saaledes helde i det mindste de Lag, der svare til Bølgeslaget i Rav-Bruunkulformationen ved Stauerhoved (Fyen), og i samme Retning maae Porphyrerne ved Liimfjorden være flyttede, dersom man vil aflede dem fra Christiania-Egnens Overgangsbjerge."

Den Bevægelse, som har foranlediget Dannelsen af den tredie Afdeling af Rullesteensformationen, synes at være gaaet ud fra Østersøen. "Da dennes Forbindelse med Kattegat over det Parti af Sverige, som indeholder de store Indsøer, og Forbindelse med det hvide Hav blev afbrudt ved Landets successive Hævning, maatte den botniske Bugt med den store Vandmasse, som de russiske og svenske Floder tilføre den, søge Udvej i den Retning, hvor Modstanden var mindst. Den gjennembrød de løse Overgangsstenarter, hvis Levninger vi endnu finde i en Række fra Ladoga Søen til Bornholm. Dette Gjennembrud har dannet vor Rullestenssand-Formation $\left.\ll^{5}\right)$.

Af Skallerne fremgik det, at Klimaet i Rav-Brunkulformationens Tid var omtrent som nu ved Middelhavet, i Rullestenslerets og i Rullestenssandets Tid omtrent som nu i Danmark. En Istid kunde der altsaa ikke være Tale om. Fra Isbjerge kunde Rullestensleret ikke stamme, da dets Bestanddele maatte blive sorterede ved at synke gennem Vandet; desuden hidrørte en stor Del af dets Materiale fra Kridtformationen i og ved Danmark, og kunde saaledes ikke være hidført længere borte fra. Skurstriberne var et Skærgaardsfænomen; de var dannede ved, at Sten, som oftest indefrosne i Flager af Havis, var skubbede hen over Klipperne af Bølgeslaget, mod hvilket Rundhæller- 
nes Læsider vendte. Paa Baggrund af saadanne Anskuelser maa Forchnammers Opfattelse af Røgle Klint ses.

Da Forchinmer i Røgle Klint fandt saavel Plastisk Ler som Glimmerler med tertiære Forsteninger, da Tellinaleret (hvori han ikke fandt Skaller) meget ligner Glimmerler og af ham antoges for at være dette, og da Sandlagene indeholder Glimmer og ofte ligner det tertiære Glimmersand, er det naturligt, at han regnede Hovedmassen af Aflejringerne i Røgle Klint til Rav-Brunkulformationen. De stærke Forstyrrelser, som findes i Parti IX, interesserede ham mest. De omtales og

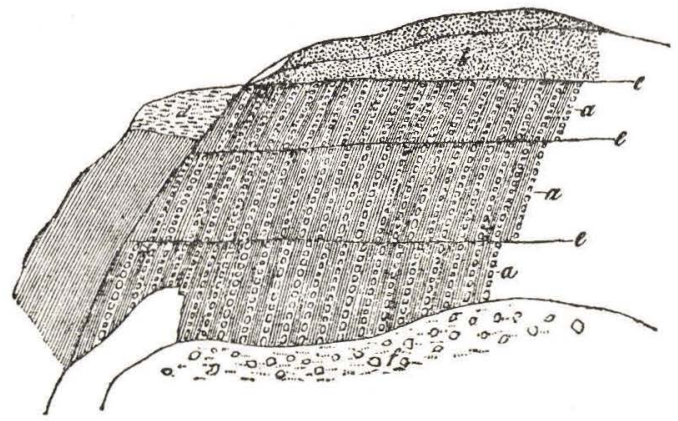

Fig. 1. Forchhammers Skitse af „Staverhoved» i Dansk Ugeskrift 1842:

"Laget a. a. a. er skifrigt Leer med mange Rullestene i samlede, lodrette Lag. b et overliggende Lag af nyere Oprindelse, som ikke har lidt af Hævningen, og altsaa er yngre. e. ere Gange, Kløfter, der have været lodrette, men ved Omvæltningen ere blevne horizontale. f. ere nedfaldne Masser".

Esquisse de Forchhammer, sur »Staverhoved", dans le Journal hebdomadaire danois de 1842:

La couche a. a. a., désigne de l'argile schisteuse contenant une grande quantité de pierres roulées. Elle forme un assemblage de couches verticales. b, désigne une couche superposée, de source plus nouvelle, n'ayant subi aucun soulèvement et qui, par conséquent, est plus jeune. e, désigne des filons et des fentes qui ont été verticales, mais qui, par renversement, sont devenus horizontales. f, désigne des masses écroulées.

afbildes gentagne Gange af ham i hans Skrifter fra de nærmest følgende Aar, hvor han beskriver »Kattegatpartiet" i Rav-Brunkulformationen $^{6}$ ), udførligst i de anførte Afhandlinger i Dansk Ugeskrift og i Poggendoff's Annaler.

»Det vedføjede Træsnit, hvorpaa et Gjennemsnit af Kysten ved Staverhoved i det nordlige Fyen er fremstillet, viser Rullestenene i den ældre (Brunkulførende) Rullesteensformation, men tillige hvorledes disse Lag ere rejste i en aldeles lodret Stilling. Da disse lodrette Lag af vor ældste Rullesteenformation ere bedækkede af horizontale Lag af vor yngste Rullesteensdannelse, saa følger deraf, at Hævningen af disse Lag har fundet Sted i den mellemste Formation i Rullesteensleret". 
»Die Schichten dieses Bildung [Kattegatpartiet] sind mannichfaltig gehoben, aber immer durch locale Hebungen, so dass kein gemeinschaftliches Gesetz der Schichtenstörung entdeckt werden kann. Am merkwürdigsten sind vielleicht in dieser Rücksicht die Schichten von Stauerhoved, wo dem schwarzen, glimmerreichen Thon viele Geschiebe des scandinavischen Urgebirges von der Grösse mehrerer Kubikfuss regelmässig eingelagert sind, und wo das ganze Schichtensystem unter einem Winkel von $80^{\circ}$ gegen NO. einschiesst. Ganz in der Nähe dieses Conglomerats finden sich Versteinerungen in einem grünlichen Sande, unter anderen habe ich Pectunculus polydonta darin gefunden«.

Med Føje har de danske Geologer kaldt disse stejle Lag for Forchhammers Lag. Desværre er de nu næsten forsvundne.

Forсhнамmer døde den 14. December 1865. Hans Efterfølger, F. Johnstrup besøgte allerede i 1868 en enkelt Dag Røgle Klint.

Johnstrup var den Gang Tilhænger af Drivisteorien: »Stiller man sig ved Foden af f. Ex. en af de større Isbræer i Norge, seer man dens nedre Del omkredset af Blokke, der hverken i Henseende til Form eller Beskaffenhed ere forskjellige fra de tilsvarende Sten i vor Rullestensformation, og det er heller intet Under; thi de er umiskjendelige Beviser for, at de nordligste Lande i Europa (saavel som ogsaa i NordAmerika) have været bedækkede med Is i en Periode, der gik umiddelbart foran den nuværende. Det er det samme Materiale og de samme virkende Kræfter, kun med den Forskjel, at Stenblokkene i Nutiden flyttes gjennem et mindre, i Fortiden derimod gjennem et større Rum, nemlig fra de norske og svenske Fjeldstrækninger ned paa de nuværende danske Sletter, der den Gang dannedes i Havet af alle de ved Isbræerne nedbragte grovere saavel som finere Dele». Om Indlandsisens Udstrækning mente Johnstrup den Gang: »Det er meget rimeligt, at paa den Tid, da Ismassen havde den største Mægtighed og Udstrækning, har den ikke blot dækket hele den skandinaviske Halvø (og Finland), men tillige udfyldt baade den botniske Bugt og Østersøen $\left.\ll^{\top}\right)$.

Ved Besøget i 1868 forfattede Johnstrup en Del Notater til en Beskrivelse af Røgle Klint, men han offentliggjorde dog aldrig en Beskrivelse af Klinten. Tellinaleret omtaler han som »sort og brunt Glimmerler". Notaterne findes i Danmarks Geologiske Undersøgelses Arkiv i hans Notebog Nr. 11, S. $\left.1-23^{8}\right)$.

1873 besøgte Johnstrup atter Røgle Klint. Han indsamlede da i Tellinaleret nogle Skaller, som opbevares i Mineralogisk Museum under Numrene 1873. 1528 - 50. Nogle af dem er etiketterede: »Knuste Skaller i nedskredet Brunkuller mellem Strib og Stauerhoved«. Det fremgaar deraf, at Johnstrup stadig opfattede Tellinaleret som tertiært. 
Nr. 1537 er af O. Møвсі bestemt som Tellina calcarea? men det er dog ikke rimeligt at tro, at han — i Modsætning til Professor Mineralogiæ - har anset Tellinaleret for kvartært, idet han meget godt vidste, at der i de engelske Crag-Aflejringer forekommer en med Tellina calcarea meget nær beslægtet Form, maaske kun en Varietet af Hovedformen.

1884 besøgtes Røgle Klint af daværende Assistent ved Mineralogisk Museum, senere Statsgeolog Dr. K. J. V. Steenstrup. Af Etiketterne paa de af ham indsamlede Skaller: »1884. 221. Tellina i en løs, graa, glimmerholdig Ler, Røgle Klint, Strib«, og »1884. 222. Saxicava i samme Ler«, fremgaar det, at han har været paa det rene med, at Tellinaleret er kvartært.

Danmarks Geologiske Undersøgelse paabegyndte 1889 under Ledelse af den senere Professor N. V. Ussing en Undersøgelse af Kystlandet i det nordlige Fyn, og da denne Undersøgelse Aaret efter naaede Omegnen af Strib, opmaalte og aftegnede hans Assistent, daværende stud. polyt. senere Lektor N. Chr. Lunding den 15.-30. Sept. 1890 et fuldstændigt Profil af Klinten fra dens vestlige Ende ved Røgle Mose til Stutterigaarden ved Baaring Vig. Profilet er tegnet i Forholdet 500 Alen $=6^{5} / \mathrm{s}$ Tomme eller $1: 1811$. Trods det, at Klinten den Gang var betydelig mere tilskreden og bevokset end senere, er det saa omhyggeligt udført, at det har været os en værdifuld Rettesnor ved vore Undersøgelser i 1913-14. Saavel paa Profilet som i sin Dagbog betegner Lunding Tellinaleret, der indeholder en Del Glimmer, som »Glimmerler«, ganske vist uden udtrykkelig at sige, at det er tertiært, hvilket vel viser, at Forestillingen om dets kvartære Alder endnu ikke var trængt helt igennem. De af Lunding i Tellinaleret indsamlede Skaller bestemtes af Dr. C. G. Johs. Petersen 1891 til Tellina calcarea, Tellina baltica og Saxicava rugosa, »under Forudsætning af, at Dannelsen ikke er tertiær $\left.\ll^{9}\right)$. Samme Aar fandt Inspektør E. Østrup Diatomeer i en Prøve af Tellinaleret, taget i Klintens nordvestligste Pynt, $340 \mathrm{~m}$ NNV for Christiansminde; de tyder paa »en Bundfældning i et koldt Hav $\left.\ll^{10}\right)$. Lundings Profiltegning er aldrig bleven publiceret; den hører til de Arbejder, som udføres af Assistenten til Brug for Statsgeologen, hvem Udarbejdelsen af det geologiske Kortblad er overdragen.

I Sommeren 1892 foretog den svenske Statsgeolog Henr. Munthe en Rejse til Danmark og Nord-Tyskland for at studere interglaciale Aflejringer. Han tog først til København, hvor han deltog i det 14 . skandinaviske Naturforskermøde. Paa dette viste Ussing ham Prøver af Tellinaleret og »den Profil, som visade lerans sannolikt interglaciale läge $\left.{ }^{11}\right)$.

Ussing og andre af de yngre danske Geologer opfordrede ham til ogsaa at besøge Røgle Klint, hvilken Opfordring han fulgte. Ved denne 
Lejlighed paaviste han for første Gang Forekomsten af MolluskskalFragmenter i de nederste Sand- og Gruslag i »Sandprofilet« (Parti I) og optog et Profil af denne Del af Klinten. Han publicerede dog ikke den Gang sin Undersøgelse, kun i Afhandlingen »Über die sogenannte »undre grålera« und einige darin gefundene Fossilien ${ }^{12}$ ) omtaler han i Forbigaaende, at Profilet bestaar »innerhalb gewisser Theile des kleinen Beltes von oben gerechnet aus 1. jüngerer Moräne, 2. interglacialen Sand- und Grus-Bildungen sowie aus 3. unterer Moräne«. Han nævner ikke Lokalitetens Navn, men af en senere Publikation ${ }^{13}$ ) fremgaar det, at den er det ovennævnte »Sandprofil«, og at han opfatter Sandet som marint.

Danmarks Geologiske Undersøgelses Arbejder i det nordvestlige Fyn blev først fortsat 1893, da under Ledelse af Statsgeolog Victor Madsen. Ved disse Arbejder foretog han ogsaa Undersøgelser af Røgle Klint, hvoraf nogle er publicerede i Afhandlingen »Istidens Foraminiferer i Danmark og Holsten og deres Betydning for Studiet af Istidens Aflejringer $\left.\ll^{14}\right)$. Tellinaleret skildres (S. 104) som »en glimmerholdig, lagdelt Lerart, der indeholder Skaller af højnordiske Muslinger. I fugtig Tilstand er den sort eller blaasort; naar den er tør, bliver den derimod brunlig graa". I Klintens Nordvestpynt (Nr. 13, Parti VI) findes nederst Tellinaleret, der her indeholder Skaller af Saxicava rugosa og Tellina calcarea; over dette findes et Gruslag med mange store Sten, der atter overlejres af en tynd Bænk af graat Moræneler og af lagdelt Sand. Over dette findes der som øverste Lag i Pynten gult Moræneler. Her har man ikke Adgang til at se det skalførende Lerlags Underlag. Dette er imidlertid synligt i Partiet Sydvest for Vejen, der fører op til Gaarden Christiansminde (Parti III). Her træffes nederst et Lag af sandet, blaasort Moræneler; over dette findes det glimmerholdige Ler, der her kun er et tyndt Lag og ikke indeholder Skaller, og som gaar jævnt over i gulligt Sand. Disse Lag overlejres af Gruslaget med de mange store Sten, der atter dækkes af vekslende Lag af Grus, Sand og tynde Bænke af Moræneler, og øverst findes gult Moræneler. Lejringsforholdene oplyses ved en Skitse af disse Dele af Klinten (Partierne III -VI). Da Tellinaleret i det sydvestligste Parti hviler paa Moræneler, og da der i begge Partier findes Moræneler øverst i Klinten, slutter Forf., at det er »aflejret i Begyndelsen eller i Slutningen af en interglacial Periode«. Ved de i 1913-14 foretagne Undersøgelser viste det sig imidlertid, at der mellem Tellinaleret og det underliggende Moræneler i Parti III findes en Dislokation, og at Tellinaleret og de overliggende Lag er skudt op over det underliggende Moræneler, som er yngre end Tellinaleret, hvorfor Grundlaget for Forf.'s Slutning ikke er rigtigt. Alligevel er Tellinaleret interglacialt, idet det i Parti V un- 
derlejres af hvidt Smeltevandssand og i Parti IX tillige af det ældste Moræneler.

Paa S. 169 omtales »Sandprofilet« (Parti I): »I Røgle Klint ved Lillebelt, strax Øst for Røgle Mose ved Strib, haves øverst omtrent $2 \mathrm{~m}$ rødgult, forvitret Moræneler, der dækker indtil $16 \mathrm{~m}$ lagdelt Diluvialsand og Grus med vandret, uforstyrret Lagdeling; under dette stikker der hist og her frem af Raset ved Klintens Fod, indtil $5 \mathrm{~m}$ over Havfladen, blaat Moræneler med vandret Overflade. I Gruslagene kan man ved nogen Søgen finde Skalstumper af Mollusker». Der fandtes mere eller mindre rullede og slidte Skalfragmenter af Nassa reticulata, Tapes aureus, Cyprina islandica, Cardium edule, Mytilus edulis, Ostrea edulis samt af nogle ikke nærmere bestemte tertiære Mollusker. Paa S. 105 og 169 meddeles Fortegnelser over de i Tellinaleret og i Gruslagene fundne Mollusker og Foraminiferer.

Tydningen af "Sandprofilet" gav i de følgende Aar Anledning til en til Tider ret skarp Diskussion mellem Henrik Munthe og Victor Madsen. Munthe gør sig til Talsmand for den Opfattelse, at Sandet i »Sandprofilet« er marint og ikke, som MADSEN har hævdet, glaciofluvialt: "Alldeles förkastligt synes det i hvarje fall vara at, såsom MADSEN gjort (Istidens Foraminiferer sid. 166-170), hänföra till »hvitåbildningar« äfven gruslager, som innehålla talrika skal af en rik marin fauna af ställvis öfvervägande sydlige molluskarter. (Jfr. särskildt Favrskov och Rögle Klint) ${ }^{15}$ ). I sit Svar hævder Madsen, at hans Opfattelse er den rigtige: »Intetsomhelst tyder paa, at skalstumperne ere primært indlejrede, eller paa, at vi overhovedet have med marine aflejringer at gøre. I Røgle Klint er fragmenter af tertiære molluskskaller næsten lige saa hyppige i gruslagene som kvartære $\left.\ll^{16}\right)$. Herpaa svarer Munthe: "att i profilen vid Rögle Klint (Fyen, Stribtrakten), hvilken jag hade tillfälle att undersöke sommaren 1892, det paa den undre moränen hvilande sandblandade gruslagret befanns innehålla - förutom sparsamma skalfragment af tertiära mollusker o. s. v. — rätt talrikt hela skal af Nassa reticulata L.; sällsyntare, föga skadade exemplar af Cerithium reticulatum Da C. och Cardium edule L. samt smärre fragment af Mytilus, Tapes o. s. v. Enligt min åsigt föreligger därstädes en strandbildning af verklig interglacial karakter innehållande en tempererad fauna, som lefvat på platsen vid tiden för tillkomsten af detta lager $\left.\ll^{17}\right)$.

I Afhandlingen »Studien über ältere Quartärablagerungen im südbaltischen Gebiete ${ }^{18}$ ) offentliggør Munthe da den endelige Beretning om sin i 1892 foretagne Undersøgelse af »Sandprofilet« i Røgle Klint og præciserer sin Opfattelse af dette. Han udtaler, at Madsens Skildring i »Istidens Foraminiferer" i det væsentlige stemmer overens med hans Iagttagelse, men medens MADSEn anser Sand- og Gruslagene for 
at være »Hvitåbildningar», mener Munthe, at de delvis er virkelige marine Aflejringer. I den nedre Moræne har Munthe samlet: brunrød, postarkæisk Granit fra Åland (eller Ångermanland?) 2 Stk., BredvadPorfyr 1 Stk., rødbrune nedresiluriske Kalksten, som if. Wiman hører til Limbata-Typen og enten er fra Jemtland eller den bottniske Bugt eller Öland 6 Stk., desuden 2 Sten, maaske af Planilimbata-Kalk; endvidere blev der fundet nogle Sten af graa Silurkalk, af hvilke nogle sandsynligvis er baltiske og andre formodentlig stammer fra Skaane. Af Flintesten fandtes flere, men ingen hvidprikket Flint fra det nordlige Skaane.

»Unmittelbar auf dieser unteren Moräne ruhen etwa 2 Meter mächtige, kiesige und sandige schalenführende Lager, die gut geschichtet sind und zuweilen diskordante Schichtung aufweisen; darauf folgen sandige, geschichtete Lager, weiter nach oben zu mit 3 dünnen Thonrändern und zu oberst mit kiesigen, dünnen Lagern«.

I den øvre Moræne fandtes brunrøde,, postarkæiske Graniter fra Åland eller Ångermanland 7 Stk.

»Es scheint nur das unterste, etwa 2 Meter mächtige, kiesige Lager zu sein, das Schalen von quartären Mollusken und Foraminiferen enthält — daneben finden sich, obwohl in geringerer Menge, tertiäre Fossilien«. Efter Fortegnelser over de fundne kvartære Mollusk- og Foraminiferskaller fortsætter Munthe: »In den übrigen Lagern scheinen keine makroskopischen quartären Fossilien vorhanden zu sein".

»Wie bereits früher betont wurde, halte ich im Gegensatz zu MADSEN dafür, dass die unteren, kiesigen Lager, die quartäre Fossilien führen, wirkliche marine Bildungen sind, und führe zur Begründung dieser meiner Ansicht hauptsächlich die Thatsache ins Feld, dass namentlich ein paar in den Litoralbildungen im Allgemeinen häufige Arten hier ziemlich zahlreich vertreten sind, und zwar im ganzen (Nassa) oder doch wenig beschädigten Exemplaren (Cardium). Die Zusammensetzung der Fauna ist übrigens eine derartige, dass sie sich mit der Ansicht, dass die Schalen in den kiesigen Lagern primär eingebettet seien, recht gut in Einklang bringen lässt.

Ich halte es daher für wahrscheinlich, dass hier eine Strand- oder Seichtwasser-Ablagerung mit einer wenigstens der Hauptsache nach primär eingelagerten quartären Mollusken- und Foraminiferenfauna von gemässigtem Charakter — "Nordsee-Fauna — vorliegt; ferner bin ich der Ansicht, dass die Entstehung des unteren, mindestens 4 bis 5 Meter mächtigen Geschiebemergels in die Zeit der grossen (= zweiten) Vereisung fällt, und dass die obere, verhältnismässig unbedeutend mächtige Geschiebedecke zur Zeit der letzten (= dritten) Vereisung (des »jüngeren baltischen Eisstromes«) gebildet worden ist. Die unteren, fossilienführenden, kiesigen Lager verlege ich somit in 
die zweite oder jüngere interglaciale Epoche, wogegen die überliegenden, vorwiegend sandigen Lager in näherem Anschluss an das Vorrücken des "jüngeren baltischen Eisstromes" abgesetzt worden sein dürften, welcher Eisstrom nachweislich über die betreffende Gegend dahingeschritten ist".

Afhandlingen illustreres med et "Profil am Kleinen Belt, $1,5 \mathrm{~km}$ O von Stribs Leuchtthurm«.

Angaaende den virkelige Alder af Morænerne og de lagdelte Sandog Grusaflejringer i Sandprofilet se S. 17.

Paa det 15. skandinaviske Naturforskermøde i Stockholm i Juli 1898 holdt Victor MADSEn et Foredrag »Om Inddelingen af de danske Kvartærdannelser $\ll^{19}$ ), i hvilket han bl. a. sagde:

»Alderen af de fluvioglaciale Aflejringer, som danner Underlaget for det sidste Ismaximums Moræner, kan undertiden bestemmes til at være yngre end Cyprinalerets, idet de føre Cyprinalerets Skaller paa sekundært Leje; dette er f. Eks. Tilfældet med det fluvioglaciale Sand i Røgle Klint ved Strib samt ved Glamsbjerg og flere Steder i Nærheden af Gjelsted Station paa Fyen«. En Anmærkning (loc. cit. S. 7), som dog ikke blev medtaget ved Foredraget, fordi Munthe ikke var tilstede ved dette, indeholder: "Munthe har vel fornylig atter hævdet ${ }^{20}$ ), at de omtalte fluvioglaciale Lag i alt Fald delvis maa være marine; hvad han imidlertid fremfører til Støtte for denne Opfattelse, er kun lidet overbevisende. Hans Iagttagelser er ikke en Gang rigtige, idet Skalfragmenterne ikke, som han angiver det, er indskrænkede til de underste to Meter af Grusog Sandlagene; de forekommer nok saa hyppigt langt højere oppe, i alt Fald op til nogle faa Meter under det øverste Morænelerlag. Sandog Gruslagene veksler i langt højere Grad og langt mere uregelmæssigt end Munthe angiver. Var disse Lag marine, vilde Skalfragmenterne sikkert være bedre bevarede og ikke holde sig til Gruslag, hvis Kornstørrelse staar i et bestemt Forhold til Skalfragmenternes Størrelse Skalfragmenterne kan mangle aldeles i fine Sandlag, som ligger imellem to Gruslag, der fører Skalfragmenter. (Man skulde dog netop vente, at der her maatte forekomme bedre bevarede, altsaa større Fragmenter). - Foraminifererne vilde være hyppigere, Molluskfaunaen vilde ikke have et saa fragmentarisk Præg, og tertiære Skalfragmenter vilde ikke være saa almindelige, hvis det var marine Lag, vi havde at gøre med «.

Tellinaleret omtaltes kun i al Korthed, idet det (1. c. S. 15 og S. 22) henførtes til den første Interglacialtid og stilledes sammen med den øvre Del af Yoldialeret ved Esbjerg.

Foredraget fremkaldte et nyt Indlæg fra Munthes Side, hvori han fastholder sin tidligere Opfattelse uden $\operatorname{dog}$ at fremkomme med nye Argumenter for $\left.\operatorname{den}^{21}\right)$.

I Sommeren 1899 fik MADSEn Lejlighed til at underkaste "Sandpro- 
filet« en Revision, ved hvilken han konstaterede, at Skalfragmenterne forekommer i rigelig Mængde endog op til $5 \mathrm{~cm}$ under det øverste Moræneler, og at der saaledes ingensomhelst Grund er til at antage, at de nederste $2 \mathrm{~m}$ er mere marine end de over dem liggende $16 \mathrm{~m}$ mægtige Sand- og Gruslag. I hans Svar paa Munthes sidstnævnte Artikel ${ }^{22}$ ) meddeles dette med Tilføjelsen, at "selv Munthe vil vistnok ikke antage, at hele denne, indtil $16 \mathrm{~m}$ mægtige Serie af Sand- og Gruslag, som kun afbrydes af ganske enkelte meget tynde Lerlag, er marin. At ogsaa de nederste $2 \mathrm{~m}$ er fluvioglaciale, fremgaar endvidere af, at der i disse Lag saavel som i den hele Lagserie ses udpræget diskordant Parallelstruktur, udviklet til en Skønhed og Fuldkommenhed, som man kun træffer den ved fluviatile Lag, og aldrig ved marine Lag«, hvilket illustreres ved et Fotografi af Sand- og Gruslagene c. $1 \mathrm{~m}$ over det nederste Moræneler. "Hertil kommer endvidere, at den Fauna, som Munthe angiver fra de nederste Lag, er alt for fragmentarisk og forekommer for meget blandet med tertiære Former, til at den kan forekomme paa primært Leje, og det til Trods for, at vel næppe alle Formerne er tagne in situ. Nogle af dem hidrører antagelig fra de højere Lag og er ved Skred komne ned i de løse Sandmasser ved de nederste Lag, som for en stor Del er dækkede af saadant, nedskredet, løst Sand. Disse Former bør ikke medregnes til de nederste Lags Fauna, og denne er vistnok i Virkeligheden endnu mere fragmentarisk end det fremgaar af Munthes Liste".

I sit Svar paa denne Artikel $^{23}$ ) fastholder Munthe stadig sin Opfattelse, at de nedre Gruslag, som fører kvartære Skaller, er virkelige marine Dannelser, idet et Par Arter, som i Reglen er hyppige i Litoralaflejringer, er ret talrigt repræsenterede i dem, nemlig i hele Eksemplarer Nassa (i $10 \mathrm{l}$ Grus fandtes 8 Ekspl.) eller i lidet beskadigede Eksemplarer Cardium. Af de øvrige fandtes hele Skaller af nogle smaa Ostrea, et Par Anomia sp.? og en lille Saxicava rugosa, og ubetydelig beskadigede nogle faa Cerithium reticulatum, 1 Hydrobia ulva, 1 Rissoa sp. og 1 Turritella terebra. Af Mytilus edulis fandtes smaa Fragmenter, af Tapes aureus nogle Fragmenter og af Syndosmya alba? 1 Fragment.

»At skalfragmenterne forekomme i rigelig mængde endog op til $5 \mathrm{~cm}$ under det øverste moræneler« inom någon del af den långa profilen detta var emellertid icke fallet inom den vestliga, af mig företrädesvis undersökta delen, såsom framgår af den beskrifning och profil jag lemnat öfver densamma - beror enligt min mening delvis därpå, at de föreliggande interglaciala lagren vid landisens framrykande ställvis till större och ställvis till mindre grad omarbetats till fluvioglacialt material, hvari man icke kan vänta att finna annat än fragmentariska eller paa sin höjd jemförelsesvis få hela molluskskal.

Den under debatt farende frågan eger sitt största interesse ur den 
synspunkten, att man enligt min mening här har att göra med en strandeller grundvattenaflagring, som är ekvivalent till den på djupare vatten afsatte »cyprinaleran« inom det sydbaltiska, mera sänkta området, och sålunda lemnar stöd för den åsigten, att man någonstädes inom norra delen af Fyn eller något nordligare har att förlägga kustlinien för en af de båda yngsta interglaciala, i det sydbaltiska området inskjutande tempererade hafsarmerne - eller m. a. o. 0-isobasen för den dátida landsänkningen."

At dette ikke er rigtigt, fremgaar af den i 1913-14 af Forfatteren udførte Undersøgelse, idet Stentællingerne har vist, at den nederste Moræne i »Sandprofilet« er afsat under den sidste Nedisning og saaledes er yngre end Cyprinaleret. Sandet og Gruset i "Sandprofilet", som er yngre end den nederste Moræne, er altsaa ogsaa yngre end Cyprinaleret og kan ikke have haft nogen Forbindelse med dette.

Angaaende Madsens Fotografi af den diskordante Parallelstruktur i »Sandprofilets" nederste Sand- og Gruslag siger Munthe, at en lige saa smukt udviklet diskordant Parallelstruktur kan findes i Litorina- og Ancylus-Strandvoldene paa Gotland og Öland, men fraset dette »är det ju tänkbart, att den förut åberopade fluvioglaciala erosionen ställvis kunnat drabba de interglaciale lagren till den utsträckning, att dessa blifvit i sin helhet omlagrade, d. v. s. ända ned till den undre moränen, som utgör deras liggande».

"Af hvad ofvan blifvit sagdt framgår alltså, att jag icke kan tillmäta något af MADSENS argument någon större betydelse, utan anser jag mig alltjemt ha skäl för min åsigt att den understa, vid pass $2 \mathrm{~m}$ mäktiga delen af den sedimentära serien i den omordade Røgleklintprofilen åtminstone ställvis och $i$ allt fall den vestliga sträcka, jag hade tillfälle närmare undersöke 1892 (hvilket möjligen redan 1893 var forstörd i följd af »de forandringer, som stadig foregå (här) ved havets erosion«), är en verklig interglacial, marin strand- eller grundvattensaflagring, innehållande en molluskfauna af tempererad prägel. Dessa bildningar öfverlagras i sin tur af hvad vi kallat »fluvioglaciala« sediment, som dock delvis - nemligen ler- och de finere sandlagren - snarare äro att anse saasom afsatte i et stillastående vatten, d. v. s. i hafvet eller sannolikare i en insjö framför iskanten, hvarefter landisen öfverskridit det hela och efterlemnat den »öfre moränen».

Et Svar paa Munthes sidste Artikel, der udkom i Marts Heftet af Geol. Fören. i Stockholm Förh., blev af Madsen i April sendt til Redaktionen af Geol. Fören. i Stockholm Förh. med Anmodning om Optagelse. Først i December fik han det tilbage med Meddelelse om, at det ikke kunde optages. Han lod det da trykke som et »Brev til Hr. Statsgeolog, Dr. phil. H. Munthe fra Victor Madsen« hos Nielsen \& Lydiche, København 1900, og udsendte det til Munthe og andre interesserede. 
I »Brevet« konstaterede Madsen, at han nu havde faaet Munthe saa vidt, at han indrømmer Muligheden af, at den fluvioglaciale Erosion stedvis har kunnet angribe de interglaciale Lag i den Udstrækning, at de i deres Helhed har kunnet blive omlejrede endda ned til den nedre Moræne. Der er da noget Haab om, at han kan blive omvendt til den Anskuelse, at hans interglaciale Lag alle Vegne i den vestlige Del af Røgle Klint er blevne borteroderede eller omlejrede til fluvioglaciale Lag, saa at disse »interglaciale« Lag omsider kan gaa ud af Sagaen.

Hvor der forekommer Lokalmoræner af Cyprinaler eller fluvioglaciale Sand- og Gruslag, dannede ved Udslæmning af disse Lokalmoræner eller direkte af Cyprinaler, kan disse Aflejringer indeholde Skaller og Skalfragmenter i særdeles betydeligt Antal og være rigere paa dem end de omstridte Lag i Røgle Klint. Antallet af Skaller og Skalfragmenter kan saaledes ikke godtgøre, at de omstridte Lag er marin e. Det samme gælder Skallernes Bevaringstilstand. Ogsaa i de højere Sand- og Gruslag i den vestlige Del af Røgle Klint forekommer der sine Steder Nassa i ret rigelig Mængde i hele eller kun lidet beskadigede Eksemplarer. I disse Lag er der ogsaa fundet enkelte smaa, næsten ubeskadigede Cardium, ja endog et næsten helt Eksemplar af den tertiære Aporrhaïs speciosa. Men der er jo Enighed om, at disse Lag er fluvioglaciale. Ser man nærmere paa, hvilke Skaller det er, som forekommer hele, og hvilke det er, der findes som Fragmenter i fluvioglaciale Lag eller Lokalmoræener af Cyprinaler i Vest-Fyn (og i de omtvistede Lag i Røgle Klint), vil man se, at det er Snegleskallerne og de smaa Muslingeskaller (smaa Ostrea, smaa Saxicava, smaa Cardium og Corbula), som forekommer hele (eller kun lidet beskadigede), hvorimod de større og tilsyneladende mere modstandsdygtige Muslingeskaller (Cyprina, Tapes, Mytilus, store Cardium, store Ostrea) kun forekommer i Fragmenter. Dette er uforstaaeligt, hvis Skallernes fragmentariske Tilstand skulde være bevirket ved Brændingerne i det interglaciale Hav, men det er let forklarligt, hvis man antager, at Skallerne er udslæmmede af Cyprinaler eller af Cyprinaler-Lokalmoræner og befinder sig paa sekundært Leje i de omtvistede Lag i Røgle Klint. I Cyprinaleret i Ristinge Klint f. Eks. ser man, at de større Muslingeskaller næsten altid forekommer knuste, hvorimod man ofte træffer de mindre Muslingeskaller og Snegleskallerne hele, og man forstaar let, at omdannes saadant Cyprinaler til en Lokalmoræne og udslæmmes denne, har de Skaller, som ikke var knuste i Cyprinaleret, dog nogen Chance for at kunne indlejres hele i de fluvioglaciale Lag, hvorimod de Skaller, som allerede var knuste i Cyprinaleret, kun kan findes som Fragmenter i de fluvioglaciale Lag. At de omtvistede Lag i Røgle Klint kun indeholder Fragmenter af de stør e Muslingeskaller, men 
derimod ogsaa hele smaa Skaller af Muslinger og Snegle, godtgør sa aledes ingenlunde, at disse Lag er marine, men langt snarere, at de er fluvioglac i a le.

Madsen hævder endvidere, at Faunaen indeholder for faa Arter til, at det kan dreje sig om en marin Fauna paa primært Leje, at det netop er i den af Munthe undersøgte, vestlige Del af Røgle Klint, at Skalfragmenterne forekommer i rigelig Mængde endog op til $5 \mathrm{~cm}$ under det øverste Moræneler, og at hans Afbildning af den diskordante Parallelstruktur i de nederste Sand- og Gruslag ingenlunde har faaet et overdrevent »diskordant" Udseende ved Ras, men at det er typisk for de nederste Lag.

»Brevet« blev det sidste Indæg i den lange Diskussion. De øvrige i denne omhandlede Spørgsmaal om hvilke af Foraminifererne, der er kvartære og hvilke der er prækvartære, Prioritetsspørgsmaalene, og om det første Anlæg af Lillebelt, har ingen Betydning i denne Sammenhæng. De, som interesserer sig for disse Spørgsmaal, maa henvises til de originale Artikler.

I Maanederne Juni og September i Aarene 1913 og 1914 foretog Forfatterne en indgaaende Undersøgelse af Røgle Klint, hvis Resultater publiceres i denne Afhandling efter at være blevne reviderede i September 1915.

Den 11. Jan. 1915 holdt Forfatterne i Dansk geologisk Forening Foredrag om »Røgle Klint ved Strib«, i hvilke Foredrag Resultaterne af Undersøgelserne af Klinten fremlagdes. De gav Anledning til en Diskussion om »Aarsagen til Dislokationerne i vore Klinter" i Foreningen den 22. Febr. 1915, som indlededes af MADSEN ${ }^{24}$ ), og hvori han gjorde sig til Talsmand for den Hypotese, at Dislokationerne i vore Klinter er tektoniske, og det endskønt han ved Detailundersøgelserne i Ristinge Klint i 1903 var kommen til den Anskuelse, at dennes Dislokationer skyldtes Istryk. Sagen var nemlig den, at det ved Detailundersøgelsen af Røgle Klint i 1913-14 havde vist sig, at denne Klint ikke er bygget paa samme Maade som Ristinge Klint, idet Lagserierne i Partierne VII-IX hælder mod hinanden. Dette bevirkede, at Forfatterne mente at maatte forlade Istryk-Hypotesen og opfatte Dislokationerne i Røgle Klint som tektoniske, og denne Anskuelse førtes saa over paa vore andre Klinter. Et Besøg ved Lønstrup Klint sammen med Axel Jessen i Forsommeren 1915 bestyrkede Forfatterne i denne Antagelse, idet de fik det bestemte Indtryk, at Dislokationerne i denne Klint ikke kunde skyldes Istryk ${ }^{25}$ ). Alligevel var de ikke helt sikre paa deres Opfattelse af dette Forhold, idet det var vanskeligt for dem at forstaa Tektoniken i Røgle Klint i alle Enkelthederne, og ikke mindre, at afgrænse de Fænomener, som med Sikkerhed skyldes Ind- 
landsisens Indvirkning, fra dem, som k a n være tektoniske, og dette bevirkede, at Trykningen af Røgle Klint Afhandlingen udskødes i Haab om, at Spørgsmaalet efterhaanden vilde klare sig ved gentagne Revisioner af Klinten.

Et nyt Lys kastedes over Dislokationsspørgsmaalet ved KarL Gripps Iagttagelser paa den hamburgske Spitsbergen-Ekspedition $1927^{26}$ ), idet han fandt, at flere af de Gletsjere, som han undersøgte, havde trykket det til stor Dybde haardtfrosne Forland op foran sig til et System af parallele Volde, der naaede Højder af $30-60 \mathrm{~m}$. Foran HolmstrømGletsjeren iagttoges over 30 saadanne parallele Volde, der strakte sig over et buet Terræn paa flere Kilometers Længde og 1 Kilometers Bredde. De Profiler, som Smeltevandsfloderne ved deres Erosion havde frembragt gennem disse Volde, viste dels store Foldninger og dels skraatstillede Lagserier med Overskydninger af samme Art som i Lønstrup og Ristinge Klinter, der af GrIPP sammenstilledes med Spitsbergens "Stauchmoränen«-Volde.

Disse Iagttagelser bragte Axe Jessen og MAdsen til atter at gaa over til Istryk-Hypotesen for Lønstrup Klints ${ }^{27}$ ) og Ristinge Klints Vedkommende. Derimod syntes denne Hypotese stadig ikke at være anvendelig paa Røgle Klint. Klinten grænser nemlig mod Øst op til en mindst $3 \mathrm{~km}$ bred Horst af Plastisk Ler, som kun er dækket af Moræneler med ringe Mægtighed. Det Plastiske Ler er endda hvælvet saa højt op, at dets nederste Del med de vulkanske Askelag kommer til Syne i Midten, Nordvest for Holmehus. Det ophvælvede Parti naar sin største Højde $71 \mathrm{~m}$ ved den trigonometriske Station lidt Syd for Gaarden Katrinebjerg, medens Klintens største Højde er 37 m (i Parti V), og Terrænhøjden ved Stutterigaarden er $38 \mathrm{~m}$.

Tænker man sig, at de vestlige Partier, de, som har en vis Lighed i deres Bygning med Lønstrup Klint og med Ristinge Klint, er blevne dislocerede ved Istryk, maa Indlandsisen, efter Dislokationernes Hældning at dømme, være kommen omtrent fra Nordøst, og Klinten har da ligget i Læ for Isen af Plastisk Ler-Horsten, medens hverken Lønstrup Klint eller Ristinge Klint har ligget i Læ af Horste. Forfatterne har da, for at forklare Bygningen af Røgle Klint, grebet tilbage til en Tanke, de allerede tidligere har haft, men ikke tænkt igennem, nemlig at Dislokationerne er fremkomne ved Hævningen af Plastisk Ler-Horsten umiddelbart Øst for Klinten, hvis østligste Parti grænser op til Horsten med omtrent lodrette Lag. At Hævningen er foregaaet med stor Voldsomhed fremgaar af, at næsten hele Oligocænet og det meste af Tellinaleret i de lodrette Lag er forsvundet. Forholdene her er analoge med Forholdene ved de nordtyske Salthorste, som paa samme Maade begrænses af stejltstaaende Lag. Dislokatio- 
nerne i Røgle Klint er da at opfatte som tektoniske, maaske endda som s a lttekto n is ke. Den over $140 \mathrm{~m}$ tykke Blok af de nu lodretstaaende Kvartæraflejringer umiddelbart Vest for Horsten maatte, da Horsten hævede sig, skaffe sig Plads. Den sammentryktes da, saa at dens Tellinaler næsten pressedes ud af den, og den sammenpressede da den $675 \mathrm{~m}$ lange Klintstrækning (Partierne VIII-III) Vest for Blokken og bevirkede, at de to Overskydninger i Partierne VI og III og Foldningerne i Parti V fremkom. - Røgle Klint indtager i alt Fald en enestaaende Stilling blandt vore dislocerede Klinter.

Om den høje Beliggenhed af det Plastiske Ler i dette Omraade virkelig skyldes en oppresset, underjordisk Salthorst, vil kunne afgøres ved geofysiske Undersøgelser.

Af saadanne er der dog hidtil blot foretaget een Undersøgelse, nemlig en Bestemmelse af Magnetkraftens Vertikalintensitet. Den udførtes af A. Ebert ${ }^{28}$ ) den 9. Okt. 1930 i Katrinebjerg Skov, Station Nr. 740 paa $55^{\circ} 32,8^{\prime}$ n. B. og $9^{0} 50,0^{\prime}$ ø. L. og gav som Resultat $\div 18$ Gamma, hvilket viser, at der her findes et lokalt relativt Maximum af Magnetkraften, idet den nærmeste Station Nr. 739, 2,5 km Syd for Nr. $740,11_{2}^{1} \mathrm{~km}$ Øst for Røgle, $55^{\circ} 31,4^{\prime}$ n. B., $9^{\circ} 49,8^{\prime}$ ø. L., gav $\div 62$ Gamma, og den næstnærmeste Station Nr. 741, 2,6 km Vest for Nr. 740, lidt Vest for Provsteskovlund ved den vestlige Ende af Klinten, $55^{\circ} 32,7^{\prime}$ n. B., $9^{\circ} 47,6^{\prime}$ ø. L., gav $\div 42$ Gamma. Ogsaa den magnetiske Maaling viser altsaa, at der her findes en Horst. Den relativ store Magnetkraft skyldes formentlig Jernforbindelserne i det højtliggende Plastiske Ler og i dettes vulkanske Askelag. Af Maalingens Resultat lader sig intet slutte om, hvorvidt der i Horsten findes en oppresset Salthorst eller ej, det maa være forbeholdt Fremtiden at afgøre dette Spørgsmaal.

Efter at der i Aarenes Løb var sket Endringer i Klintens Udseende ved Havets Nedbryden af Kysten og nye Skred, foretog Nordmann og Sigurd Hansen i 1931 nogle supplerende Udgravninger i Partierne IV og V og Opmaalinger i Parti IX.

Det har nu og da vist sig nødvendigt at offentliggøre forskellige af Resultaterne af Undersøgelserne af Røgle Klint. Ved Diskussionen om »Aarsagen til Dislokationern i vore Klinter« i Dansk geologisk Forening d. 22. Febr. $1915^{29}$ ) meddelte MADSEN saaledes Hældningsretningerne i Overskydningsfladerne og i selve Lagene i Røgle Klint. Den samme Meddelelse fremkom i hans Foredrag paa det 16. skandinaviske Naturforskermøde i Oslo 1916. I »Oversigt over Danmarks Geologi« 1928 er angivet Lagrækken i Røgle Klint, og der findes en Del Oplysninger om Morænerne, om de i disse udførte Stentællinger og om Tellinaleret $^{39}$ ). Endelig findes der en Oversigt over Forholdene i Røgle 
Klint med en Skitse af en Del af Klinten i Beretningen om Dansk geologisk Forenings Ekskursion til Vejle-Fredericiaegnen d. 12.-14. Juli $1928^{30}$ ). Paa denne Skitse er der længst mod Vest (længst til Højre) under den Tellinalerflage, som danner Grænsen mellem Partierne VI og VII tegnet et Lag hvidt Sand H $(=\mathrm{a})$. Teoretisk skulde dette Sand findes her, men i Virkeligheden ser man kun enkelte tynde Smører, som rimeligvis tilhører Tellinalerets nedre Del. 


\section{Aflejringerne i Røgle Klint.}

Yed de af os foretagne Undersøgelser af Røgle Klint er paavist, at denne Klint er opbygget af følgende Aflejringer, som nævnes i deres Aldersfølge; den yngste først, den ældste sidst:
10. Moræne D.
9. Glaciofluviale Lag c.
8. Moræne C.
7. Moræne B.
6. Glaciofluviale Lag $\mathbf{b}$.
5. Tellinaler.
4. Glaciofluviale $\operatorname{Lag}$ a.
3. Moræne A.
2. Glimmerler og Glimmersand,
1. Plastisk Ler.

\section{Plastisk Ler.}

Det Plastiske Ler, af HARDER kaldet »Lillebeltsler $\left.\ll^{31}\right)$, som optræder paa Kysterne af Lillebelt, Nordøst for Fredericia og Øst for Strib, har fra gammel Tid været betragtet som Typen paa det danske Plastiske Ler. Det er en overordentlig fed Lerart, som næsten intet Sand indeholder. I fugtig Tilstand er det stærkt udskridende. Farven veksler fra graablaa og graabrun for oven til teglstensrød for neden; underordnet findes der lysegraa Lag eller Bænke i det. Det indeholder Konkretioner af kulsur Kalk og svovlsur Baryt. At det er af eocæn Alder, maa anses for at være godtgjort. En nærmere Undersøgelse af det har vi betragtet som liggende udenfor dette Arbejdes Plan.

\section{Glimmerler og Glimmersand.}

Foruden det Plastiske Ler forekommer der i Røgle Klint kun ubetydelige Rester af andre tertiære Jordarter, nemlig dels sort, magert, sandet, glaukonitholdigt Glimmerler, hvis nederste Del ved udskilte Jernforbindelser er omdannet til et brunligt Knoldelag, og dels sortebrunt eller lyst, mere eller mindre grønligt, glaukonitholdigt Glimmersand. I Knoldelaget findes daarligt bevarede, knuste Molluskskaller. Alderen af disse Dannelser maa anses for at være øvre oligocæn, tildels dog maaske nedre oligocæn. 


\section{Moræne A.}

Den ældste kvartære Dannelse i Røgle Klint er Moræne A fra den første danske Istid. Den optræder kun paa et enkelt Sted længst mod Øst, i Parti IX, Øst for »Glimmerlerkløften«, hvor den staar lodret. Den har der en Mægtighed af $5-6 \mathrm{~m}$. Den bestaar af blaasort eller sortebrunt Moræneler, hvori der kan findes talrige Sandsmører. Som Middeltal af 8 Bestemmelser er fundet, at den har Stentællingskvotienten $0,36 \pm 0,044$, idet det sidste Tal her og i det følgende angiver Middelfejlen. In situ er fundet en Rhombeporfyr, 2 Stk. plettet Flint og 7 Stk. Svovlkies.

\section{Glaciofluviale Lag a.}

Den ældste glaciofluviale Lagrække i Røgle Klint bestaar af vekslende Lag af gult og hvidt, glimmerholdigt Kvartssand og (mere underordnet) graat, stenfrit Ler. Materialet hidrører aabenbart fra tertiære Jordarter. I Lagene forekomme talrige, oftest brune eller sorte, rullede Stykker af tertiære Jordarter, snart brunkulagtige, snart mere lignende Glimmerler. I de rullede Brokker af tertiært (oligocænt?) Ler, som ligger paa sekundært Leje i den nedre Del af det glaciofluviale Sand a umiddelbart ovenpaa (Vest for) Moræne A er fundet Aftryk af tertiære Mollusker, repræsenterende Slægterne Nucula (mindst to Arter), Tellina og Dentalium. Ingen af dem kunde bestemmes til Art. De er bestemte af Th. Sorgenfrei. Der findes ogsaa enkelte Sten samt »Rullesten« af Moræneler. I denne sin typiske Form optræder Røgle Klints ældste glaciofluviale Lagrække i Østenden af Parti IX umiddelbart Vest for Moræne A med en Mægtighed af c. $20 \mathrm{~m}$. I Partierne IV, V og VII forekommer der hvidt, glimmerholdigt Sand, der ved sit Indhold af tynde Lerlag, ved at det ikke er direkte overlejret af en Moræne, samt ved, at der i det forekommer rullede Brunkulstykker og »Rullesten« af Plastisk Ler, maa anses for at høre til de glaciofluviale Lag a.

\section{Tellinaleret.}

Tellinaleret er en mørk, glimmerholdig Lerart, som indeholder en fattig, arktisk eller boreoarktisk Fauna. Det kan optræde som en ret fed Leraflejring, men i Reglen er det dog temmelig magert. Næsten overalt gennem hele Mægtigheden findes der Sandlag i det, eller det maa siges at bestaa af vekslende, tynde Ler- og Sandlag. Sandlagene tager til i Hyppighed opad og nedad i det. Alt tyder paa, at Tellinalerets Dannelse er begyndt med en Aflejring af vekslende Sand- og Lerlag, idet Sandlagene har været de overvejende, men efterhaanden er Lertilførselen taget til, saa at Lerlagene er blevet meget fremher- 
skende. Tilførselsforholdene maa dog ofte pludselig have forandret sig, eftersom Lag af skarpt, rent Sand uden Overgang veksler med Lag af fedt Ler. Mod Slutningen af Dannelsestiden er Sandtilførselen atter forøget. Tellinaleret er afsat under vor første Interglacialtid. Dets oprindelige Mægtighed kan anslaas til mindst $15 \mathrm{~m}$.

Tellinalerets Mollusker (af V. Nordmann). I Tellinaleret er fundet Skaller af følgende Mollusker: Tellina calcarea Chemn., Saxicava arctica L. (= S. rugosa L.), Modiolaria lavigata (Gray) Torell og Mya truncata $\left.L .^{40}\right)$. De to førstnævnte er de hyppigste; af Modiolaria er der kun fundet to Skal-Aftryk og af den sidstnævnte Art et enkelt Fragment. De forekommer langt fra jævnt fordelt i Aflejringen; man kan gennemsøge store Partier af Tellinaleret uden at finde en eneste Skal, kun hist og her ses en lille Gruppe paa faa Individer af Saxicava eller Tellina. At Skallerne her findes paa primært Leje, fremgaar af deres Bevaringstilstand; vel er Skallerne for Størstedelen mere eller mindre knuste paa Grund af de Forstyrrelser, Tellinaleret senere har været udsat for, men de enkelte Fragmenter ligger dog tæt sammen, nogenlunde i deres oprindelige Stilling; desuden er Skallerne ikke rullede eller slidte - men ganske vist ofte stærkt forvitrede eller opløste paa Grund af Vandtrækket gennem det stærkt revnede Ler, der ud mod Yderfladen gentagne Gange har været udsat for Tørring. Muslingernes Skaller er ofte forbundne ved Ligamentet og sammenklappede.

De fundne Arter er alle gode arktiske Arter, men med saa vid geografisk Udbredelse og i Stand til at kunne leve under saa forskellige Forhold saa vel i Henseende til Dybde og Bundart som Temperatur, at der saadan set ikke synes at kunne udledes noget nærmere om, under hvilke Naturforhold Tellinaleret er afsat. Tager man imidlertid i Betragtning, at disse Arter sædvanligvis findes sammen med et større eller mindre Antal andre Molluskarter, og at de langt fra er Brakvandsarter, saa kan netop den Omstændighed, at man i Tellinaleret kun har fundet disse faa Arter, give et Fingerpeg om Aflejringens Oprindelse. Det er de samme ejendommelige Forhold, som vi kan træffe paa forskellige Lokaliteter i vore andre kvartære marine Aflejringer, der er afsat under arktiske Forhold. Flere Steder i det senglaciale Yoldialer i Vendsyssel er der saaledes kun fundet de to Arter Saxicava arctica og Tellina calcarea, undertiden sammen med endnu en Art, f. Eks. Portlandia arctica, Leda pernula eller Modiolaria; i Tellinaleret ved Høve i Odsherred er kun fundet Skaller af Tellina calcarea samt en enkelt Nucula tenuis o. s. v.

Denne mærkværdige Optræden af kun ganske faa Arter, som ellers findes sammen med mange andre, minder i saa paafaldende Grad om, hvad der er paavist ${ }^{32}$ ) i de inderste Dele af Nordre Strømfjord paa Grønlands Vestkyst og sikkert ogsaa kan paavises i andre arktiske 
Fjorde, hvori Smeltevandsfloder fra Indlandsisen løber ud. Paa de store Banker, som i det Indre af Fjorden opbygges af de uhyre Masser af Ler og Slam, der føres ud med Smeltevandsfloden, fandtes kun faa og gennemgaaende yngre, levende Individer af Tellina calcarea, Yoldia hyperborea o. a., altsaa Arter, som ingenlunde under normale Forhold skyer andre Molluskarters Selskab. Det maa bemærkes, at Vandet herinde kun faa Meter under Overfladen er ligesaa salt som længere ude i Fjorden, idet Flodernes Ferskvand kun lægger sig hen over det salte Bundvand som en Kappe, der aftager i Tykkelse udad i Fjorden. Naar Faunaen paa disse Banker er saa fattig, skyldes det ganske simpelt, at de udstrømmende Lermasser ligefrem kvæler Dyrelivet. At det virkelig forholder sig saaledes, fremgaar deraf, at ligesaa snart man kom i Læ for de udvæltende Lermasser, altsaa paa Steder, hvor Vandet var klart, traf man herinde saa at sige den samme artrige Fauna som længere ude i Fjorden.

Man maa heraf slutte, at Tellinaleret i Røgle Klint er aflejret under arktiske Forhold i en Fjord, der er bleven fyldt med Ler og Sand, hidbragt af Smeltevandet fra en ikke for fjernt liggende Indlandsis.

Tellinalerets Foraminiferer (af Victor Madsen). Ved Undersøgelse af en større Prøve Tellinaler, fremkommen ved, at en Mængde mindre Prøver tagne paa forskellige Steder i Klinten blev slaaede sammen, fandtes følgende Foraminiferer ${ }^{33}$ ):

Miliolina seminulum 2 Eksp., Haplophragmium canariense 2 Eksp., Bulimina elegans 2 Eksp., Cassidulina crassa temmelig almindelig, Lagena globosa 1 Eksp., L. apiculata 3 Eksp., L. gracillima 3 Eksp., L. hispida 1 Eksp., L. striata 1 Eksp., L. sulcata 2 Eksp., L. semistriata 1 Eksp., L. squamosa ikke sjælden, L. lovigata almindelig, Nodosaria rudis 2 Fragm., N. farcimen 1 Eksp. og 2 Fragm., N. soluta 1 Fragm., N. communis 1 Eksp. og 1 Fragm., N. roemeri 1 Eksp., Polymorphina lactea almindelig, $P$. sororia almindelig, $P$. cf. oblonga almindelig, Uvigerina canariensis 1 forvitret Eksp., Globigerina bulloides typ. og var. triloba almindelig, G. aquilateralis almindelig, Patellina corrugata 1 Eksp., Rotalia beccarii var. lucida almindelig, Nonionina depressula meget almindelig, Polystomella striatopunctata 2 Eksp., P. striatopunctata var. incerta meget almindelig, Polystomella arctica meget almindelig. Nogle af de sjældnere Former er mulig i sin Tid udskyllede af tertiære Aflejringer.

Den hyppige Forekomst af den nordlige Polystomella arctica, af Polystomella striatopunctata var. incerta, af Cassidulina crassa, og af de talrige Lagena Arter, samt Mangelen af den sydlige Rotalia beccarii og den meget sparsomme Forekomst af den typiske Polystomella striatopunctata giver Tellinaleret Plads mellem de marine Kvartæraflejringer med arktisk eller boreal Fauna. 
Tellinalerets Diatomeer. I en Prøve af Tellinaler, taget i Klintens nordvestligste Pynt, $340 \mathrm{~m} \mathrm{NNV}$ for Gaarden Christiansminde, har E. Østrup ved Gennemsøgning af tre Præparater fundet følgende Diatomeer $\left.{ }^{10}\right)$ :

Actinocyclus alienus var. arctica 2 Eksp., Amphora ovalis 1 Skal, Biddulphia aurita 1 Eksp., B. Roperiana 1 Eksp., Hemiaulus sp. 1 Fragm., Chatoceros decipiens var. concreta 2 Eksp., C. Diadema Hvilesporer ret almindelige, $C$. distans Fragmenter af Horn meget almindelige, Cocconeis costata 2 Eksp., Diploneis coffœiformis 1 Eksp., D. Entomon 1 Eksp., D. Smithii 2 Eksp., Navicula sp. vistnok Nav. (Rhoiconeis) Bolleana 1 Skal, Nitzschia acicularis var? 1 Eksp., N. linearis var. tenuis en enkelt Gruppe, $N$. socialis en enkelt Gruppe, Pleurosigma elongatum 1 Fragm., Stauroneis anceps var. amphicephala 1 Eksp., Stephanopyxis sp. vistnok S. Turris var. Cylindrus forma paucispina 1 Eksp., Synedra Kamtschatica var. minor 2 Eksp., Thalassiosira gravida Hvilesporer, Trachyneis aspera 1 Fragm.

Karakteristisk for Prøven er de mange Brudstykker af ChœtocerosHorn og Hvilesporer af Chœtoceros Diadema og maaske ogsaa Thalassiosira gravida, hvis Sporer ikke kan kaldes sjældne. Af de øvrige mere enkeltvis forekommende Former tilhører nogle fortrinsvis de koldere Have. Diatomeerne i denne Prøve tyder altsaa paa en Bundfældning i et koldt Hav.

\section{Glaciofluviale Lag b.}

Denne Aflejring af glaciofluviale Lag naar sin største og smukkeste Udvikling i den østlige Halvdel af Parti IX. Ligesom den foregaaende Afdeling a, fra hvilken den paa det nævnte Sted er skilt ved Lag af graablaat, stenfrit Ler med Brokker af sort, tertiært Materiale, og ved en Tellinalerflage, bestaar den af vekslende Sand- og Lerlag, hvoraf nogle indeholder spredte Sten, men den adskiller sig fra Afdeling a ved tillige at indeholde Gruslag i stor Udstrækning. I nogle af disse Gruslag naar Stenene Barnehoved-Størrelse eller mere. De nederste Lag i denne Serie indeholder ligeledes sorte Brokker af tertiært Materiale; i en af disse, der var c. $3 \mathrm{dm}$ lang, fandtes Skaller og Aftryk af tertiære, marine Mollusker. I de øverste Lag i Serien mangler det tertiære Materiale. Mægtigheden er i Parti IX c. $11 \mathrm{~m}$.

Vest for Parti VIII er denne glaciofluviale Lagrække hovedsagelig repræsenteret ved et rustfarvet, sammenkittet Lag af rullede Sten med en Mægtighed af indtil 0,7 m. Den største Del af Stenene har vel kun en Størrelse som en Valnød eller et Eble, men mange er dog saa store som et Menneskehoved eller endnu større. I nøje Tilknytning til dette Lag findes paa flere Steder tynde Sand- og Lerlag. 


\section{Moræene B.}

Ligesom de glaciofluviale Lag opnaar Moræne B, Morænen fra vor anden Istid, sin største Mægtighed, c. 23 m, i Parti IX. Den bestaar overvejende af graabrunt, magert, sandet Moræneler. I dens nedre Del $B_{1}$ findes Bænke, til hvilke aabenbart Glimmerler for en stor Del har leveret Materialet. Stentællingskvotienten i denne Del $B_{1}$ er lav: $0,50 \pm 0,049$ (Middeltal af 7 Bestemmelser). In situ er fundet en rød Østersø-Kvartsporfyr og 3 Stk. Svovlkies.

I den øvre Del $B_{2}$ kan Moræne $B$ være blaagraa og adskilligt federe; den kan indeholde Lag og Indlejringer af Grus, Sand og stenfrit Ler. Stentællingskvotienten i denne Del $\mathrm{B}_{2}$ er ret høj: 0,82 \pm 0,026 (Middeltal af 30 Bestemmelser). In situ er fundet en Laurvikit, en rød ØstersøKvartsporfyr, en brun Østersø-Kvartsporfyr, 9 Stk. Aragonit og 7 Stk. Svovlkies.

\section{Moræene C.}

Moræne C fra vor tredje Istid bestaar i Reglen af Moræneler, der i uforvitret, tør Tilstand ser ud som almindeligt, blaat Moræneler; i fugtig Tilstand har Farven en ejendommelig, sort Tone, som antagelig hidrører fra noget Indhold af Glimmerler. Beskaffenheden kan dog variere en Del; saaledes bestaar denne Moræne i det østlige Fald i Parti VI af lys-blaa-graat, meget fedt Moræneler, der snart kan være saa godt som stenfrit, snart meget stenrigt. Den første Varietet viste sig at indeholde $38,8 \%$ kulsur Kalk, den sidste 20,2\%. Mægtigheden kan naa $24 \mathrm{~m}$.

De foretagne Stentællinger viser, at der ogsaa i denne Moræne er Forskel paa den øvre og nedre Del, idet Stentællingskvotienten i den øvre Del $\mathrm{C}_{2}$ er forholdsvis høj: 0,81 \pm 0,040 (Middeltal af 43 Bestemmelser), medens den $\mathrm{i}$ den nedre Del $\mathrm{C}_{1}$ er $0,49 \pm 0,012$ (Middeltal af 18 Bestemmelser).

$\mathrm{I} \mathrm{C}_{1}$ er fundet in situ 2 Rhombeporfyrer, en Rhombeporfyrtuf, 1 Stk. Aragonit og 12 Stk. Svovlkies.

I $\mathrm{C}_{2} \mathrm{i}$ "Sandprofilet" har Munthe samlet brunrøde postarkaiske Graniter fra Åland eller Ångermanland, Bredvadporfyr og forskellige siluriske Kalksten (se Side 16). Vi har desuden fundet in situ 2 Stk. Rhombeporfyrtuf, 4 Stk. plettet Flint, 1 Stk. Aragonit, 16 Stk. Svovlkies, et Vættelys og et Hængsel af en Pectunculus.

Hvor Tellinaleret er skudt op over Moræneler, nemlig i Partierne III og VI, er det over denne Morænes øvre Del. Det er ogsaa denne Del af Morænen, der ses under det glaciofluviale Sand i Parti I. 


\section{Glaciofluviale Lag c.}

Over Moræne $\mathrm{C}_{2}$ findes i Parti I en Række glaciofluviale Sand- og Gruslag med udpræget Krydslejring (diskordant Parallelstruktur) og af normalt kvartært Udseende. I Sandlagene optræder underordnet tynde Lerlag. Mægtigheden er i den vestligste Del af Parti I 18 m. De indeholder fra øverst til nederst en Del Skalstumper og Skaller; nogle af disse er tertiære, men de fleste kvartære, dels boreale, dels hidrørende fra ødelagte Eem-Aflejringer.

En lignende Aflejring, men betydelig fattigere paa Skalfragmenter og af langt ringere Omfang optræder i Parti VII. Da denne ligeledes hviler paa Moræne $\mathrm{C}_{2}$ er der al Grund til at tro, at den er sammenhørende med den nysnævnte, mægtige Sandaflejring.

De glaciofluviale Lag e's Indhold af Skaller paa sekundrert Leje (af V. Nordmann). I de glaciofluviale Lag c er fundet mere eller mindre rullede Skaller og Skalfragmenter af følgende tertiære og kvartære marine Mollusker:

1. Tertiær $\mathrm{r}$ - Pectunculus (Axinea) cfr. bimaculata Poli $(=P$. glycimeris L.)

Pectunculus sp.

Limopsis cfr. aurita Brocchi

Astarte Kickxi Nyst

Isocardia sp.

Cardium $s p$.

Dentalium sp.

Chenopus (Aporrhaïs) cfr. speciosus v. Schloth.

Chenopus sp.

Cassis sp.

Tritonium $s p$.

Murex?

Pleurotoma cfr. Selysi De Koninck

Pleurotoma sp.

2. Kva rtære - Ostrea edulis L.

* Anomia?

Mytilus edulis L.

Leda pernula Müll.

Cardium edule $L$.

Cyprina islandica $L$.

Tapes senescens Doederl. (= T. eemiensis Nordm.)

Tellina calcarea Chemn.

* Syndosmya (Abra) alba Wood

Saxicava arctica $L$. (=S rugosa L.)

Mya truncata $L$. 


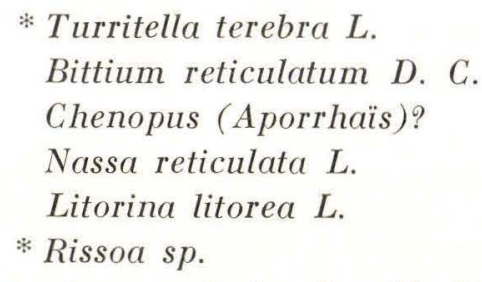

De med $*$ betegnede er anførte efter H. Munthe ${ }^{35}$ ).

I den Del af Diluvialsandet c, der optræder som en Sandlinse ovenpaa Moræne C i Pynt 20, er fundet Skalstumper af følgende tertiære og kvartære Mollusker: Pectunculus sp., Chenopus sp., Pleurotoma sp., Ostrea edulis L., Cyprina islandica L., Tapes senescens Doederl., Saxicava artica L., og Mya truncata L.?

Af de fundne tertiære Arter forekommer Chenopus speciosus baade $\mathrm{i}$ oligocæne og miocæne Aflejringer, medens Pleurotoma Selysi og Astarte Kickxi kun er kendt fra Oligocænet. Pectunculus bimaculatus er ganske vist kun kendt fra Miocænet, men den er saa nær overensstemmende med den oligocæne Pectunculus Philippi Desh., at det højst sandsynlig drejer sig om samme Art.

De tertiære Arter er bestemte af Th. Sorgenfrei.

I en Prøve af Grus fra »Sandprofilet« fandtes følgende Foraminiferer $\left.{ }^{36}\right)$ : Bulimina fusiformis 1 Eksp. friskt, B. marginata 1 Eksp. svagt forvitret, Lagena sulcata 1 Eksp. svagt forvitret, Cristellaria sp.? 1 Eksp. ikke nulevende, Senon?, Globigerina bulloides almindelig, G. cretacea ikke sjælden, G. cequilateralis ikke sjælden, Orbulina universa ikke sjælden, Discorbina bembix 3 Eksp., Senon, Truncatulina lobatula 3 smaa Eksp. svagt forvitrede. Truncatulina $c f$. dutemplei 1 Eksp. temmelig friskt, Tertiær?, Nonionina depressula 7 Eksp. friske, N. depressula var. perforata 1 Eksp. noget forvitret, Tertiær, Polystomella striatopunctata var incerta 2 Eksp. friske.

\section{Moræne D.}

Røgle Klints yngste Moræne D fra det østjydske Isfremstød optræder ved Overfladen i Parti I som Rester af forvitret Moræneler med en Mægtighed af indtil $2 \mathrm{~m}$. I de østlige Partier, og da navnlig i Parti VIII, er denne Moræne karakteriseret ved anselige Smører eller udtværede Partier af Plastisk Ler og er af temmelig fed og stiv Beskaffenhed. Dens Stentællingskvotient er 1,22 $\pm 0,050$ (Middeltal af 7 Bestemmelser). In situ i Moræne D er af Munthe i »Sandprofilet« fundet brunrøde postarkæiske Graniter fra Åland eller Angermanland. Vi har desuden in situ fundet en Rhynchonella, 1 Stk. Aragonit og 1 Stk. Svovlkies.

I en Mergelgrav lige Nordvest for Gaarden Christiansminde ses en stor Flage af Plastisk Ler med et Kalkindhold af 13,5\% i Moræne D. 


\section{Bygningen af Rogle Klint.}

en følgende Beskrivelse refererer sig i Hovedsagen til Undersøgel-
serne i $1913-14$.

Parti I. Røgle Klints sydvestligste Del, der naar en Højde af $24 \mathrm{~m}$, er i de senere Aar skredet mere og mere til, og Plantevæksten har bredt sig, men endnu staar Klinten paa en Strækning af $375 \mathrm{~m}$ dog saa ren, at man med Lethed kan iagttage dens Bygning (Fig. 2, S. 33).

Øverst ses Rester af Moræne D, rødbrunt, forvitret Moræneler, hvis Mægtighed nogle Steder endnu beløber sig til $2 \mathrm{~m}$. Under Morænen findes de glaciofluviale Lag c, regelmæssige, vandrette, udpræget krydslejrede Sandlag med enkelte underordnede, tynde Lerlag, samt finere Gruslag, der indeholder Skalstumper. Sandlagene er overvejende over Gruslagene. Nederst findes, umiddelbart paa Overfladen af den underliggende Moræne C, et Lag af Sten, der aabenbart er udskyllede af denne Moræne. Mægtigheden af disse glaciofluviale Lag er c. 18 m.

Under Sand- og Gruslagene fremtræder Moræne C, Moræneler af mørk, graa Farve, der staar med stejl Væg og naar op til c. 4 m over Havfladen. Morænen har et ret rigeligt Indhold af Kridtstumper; sine Steder findes der Gruspartier og Smører i den. Den har en temmelig vandret Overflade, der antagelig er en Denudationsflade.

Parti II. Paa den følgende Strækning, $850 \mathrm{~m}$, er Klinten bevokset, men trods Plantevæksten kan man skønne, at Klintens Bygning maa vare som i Parti I (Fig. 3, S. 33). Forneden ses, endog paa Afstand, over det meste af den omtalte Strækning en Terrasse, der naar en Højde af 5-7 m over Havfladen; den fremtræder med frisk, grøn Plantevækst, og er aabenbart dannet af Fortsættelsen af Parti I's nedre Moræneler C, der standser det Vand, der siver ned gennem de overliggende Sand- og Gruslag og lader det risle ud over sin Yderflade som smaa Væld, der stadig vander den frodige Plantevækst. Omtrent $1 \mathrm{~km}$ fra Røgle Klints Begyndelse har lidt kraftigere Væld endog bevirket Dannelsen af en stor Niche i Klinten (Fig. 4, S. 33).

Ovenover den omtalte Terrasse gør Plantevæksten et fortørret Indtryk; der optræder Gyvel, Lyng og andre »Sand-Planter». Her har vi aabenbart Fortsættelsen af Parti I's Sand- og Gruslag. 


\section{Forklaring til Fig. 2-4.}

Fig. 2. »Sandprofilet《 i Parti I. Øverst ses det indtil $2 \mathrm{~m}$ mægtige, rødbrune Moræneler D og under dette $18 \mathrm{~m}$ mægtige glaciofluviale Lag c, regelmæssige, vandrette, udpræget krydslejrede Sandlag med enkelte underordnede, tynde Lerlag, samt finere Gruslag, som indeholder Skalstumper. Under Sandlagene c stikker Moræne C, mørkegraat Moræneler, frem i en Højde af c. $4 \mathrm{~m} \mathrm{o.} \mathrm{H.} 1913$.

Fig. 3. En Del af Parti II. Klinten er bevokset. Forneden ses en $5-7 \mathrm{~m}$ høj Terrasse af Moræne C med frisk Vegetation og over denne de glaciofluviale Lag c med Gyvel, Lyng og andre »Sandplanter«. 1913.

Fig. 4. Den af Væld frembragte Niche i Sandet c over Moræne C i Parti II. 1913.

\section{Explications des figures 2-4.}

Fig. 2. »Le profil de sable« dans partie I. Au dessus se trouve l'argile morainique D.; son ton est rouge-brun et son épaisseur atteint jusqu'à $2 \mathrm{~m}$. Elle se tient sur les couches glacio-fluviales c, qui sont des couches de sable regulières, horizontales, présentant une stratification entrecroisée, bien marquée, et avec quelques minces couches d'argile inférieures, de même que des couches de gravier plus fin, contenant des fragments de coquilles. Sous les couches de sable c, se trouve la moraine C, - une argile morainique gris-sombre - qui se projette en avant, à une hauteur d'environ $4 \mathrm{~m}$ au-dessus du niveau de la mer. 1913.

Fig. 3. Une section de partie II. La falaise est largement fournie en plantes. A la base, se trouve une terrasse de $5-7 \mathrm{~m}$ de haut, formée par la moraine $\mathrm{C}$, et couverte d'une fraiche végétation. Par dessus celle-ci, se trouvent les couches glacio-fluviales c couvertes de genêts, de bruyère et d'autres »plantes de sable.« 1913.

Fig. 4. La niche produite par une source dans le sable c, par dessus la moraine C, Partie II. 1913. 


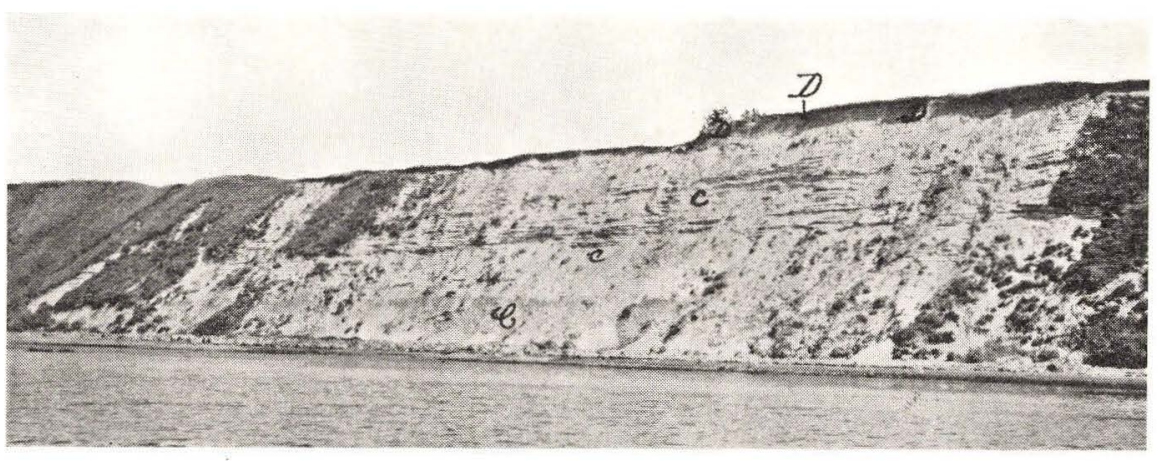

Fig. 2.

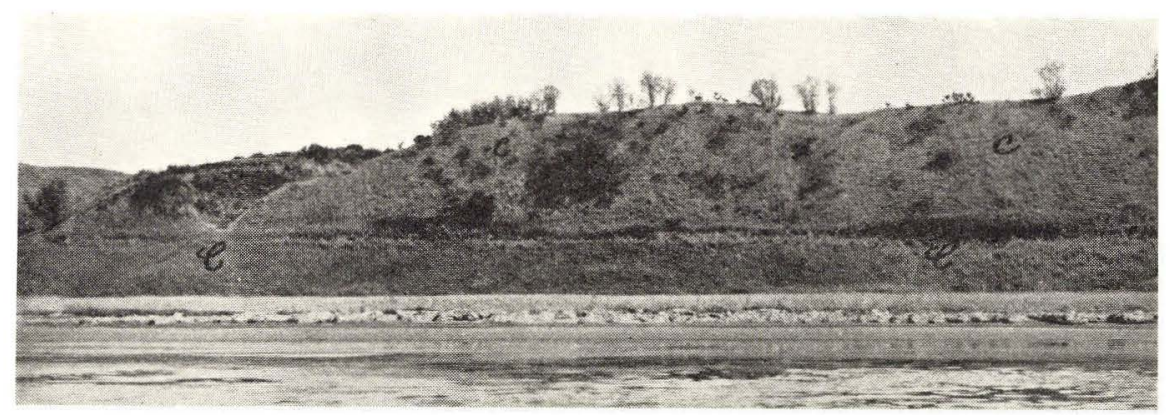

Fig. 3.

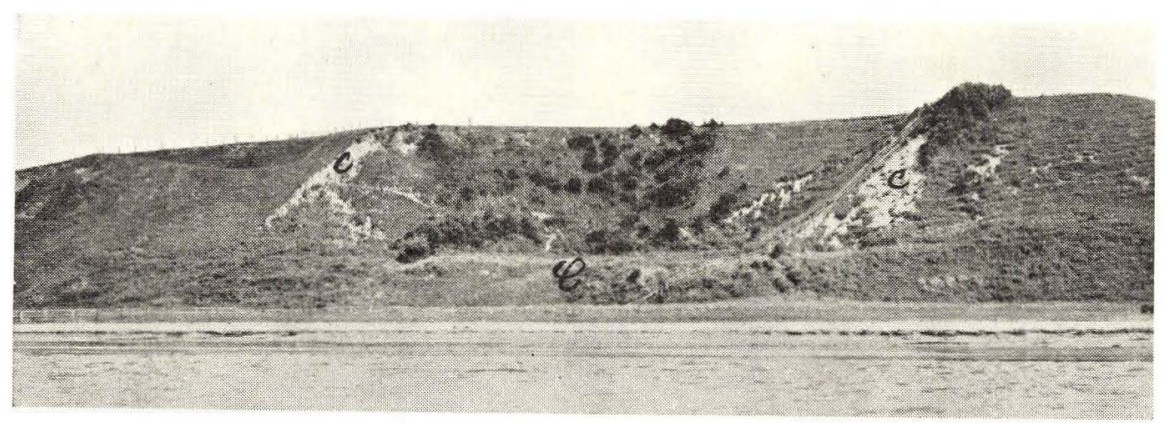

Fig. 4. 
Parti III. Det følgende Klintparti, Parti III, har en Længde af $170 \mathrm{~m}$ og naar en Højde af $35 \mathrm{~m}$. Det er ret tilskredet og græsbevokset, men ved at foretage Udgravninger forskellige Steder i det, er det lykkedes at komme til Forstaaelse af dets Bygning (Fig. 5, S. 37).

Forneden mod Sydvest findes Moræneler, der hæver sig til $27 \mathrm{~m}$ over Havet. Ved flere mindre Udgravninger har vi forvisset os om, at det er en Fortsættelse af den nedre Moræne C i Partierne I og II. Grænsefladen mellem Moræneleret og de overliggende Aflejringer er en ret stejl, skæv, krum Flade. I en Højde af c. $16 \mathrm{~m}$ maaltes dens Strygning til N. $55^{\circ} \mathrm{V}$. og dens Hældning til $40^{\circ} \bmod N .35^{\circ} \varnothing$. Nogle Meter højere oppe var Strygningen N. $40^{\circ} \mathrm{V}$. og Hældningen $30^{\circ} \mathrm{mod}$ N. $50^{\circ} \varnothing$., og atter nogle Meter højere oppe var Strygningen N. $30^{\circ} \mathrm{V}$. og Hældningen $25^{\circ} \bmod N .60^{\circ} \varnothing$. Grænsefladen er en Overskydningsflade. Over denne findes helt mod Sydvest glaciofluviale Sand-, Grus- og Stenlag b og Moræne B. Længere mod Nordøst viser der sig Tellinaler under disse glaciofluviale Lag. Lagene er skubbet op over Moræneleret C, hvorved Tellinaleret er blevet udpresset og udtværet til et kileformigt Parti, der vender Eggen opad mod Sydvest og den brede Ende nedad mod Nordøst. Øverst, helt mod Sydvest, mangler, som omtalt, Tellinaleret, og Moræneleret dækkes af Sand, der fortsætter sig ned under Tellinaleret og tilsidst taber sig, saa at Tellinaleret kommer til at hvile direkte paa Moræneleret. Forneden i Tellinalerflagen findes der ganske tynde, itubrudte Sandlag, der saaledes viser, at Tellinalerflagen er bleven brokket og udtværet under Bevægelsen op over Moræneleret.

Paa Sydvestsiden af det næseagtige Fremspring, der dannes af Tellinalerflagens tykke Ende, findes der over Tellinaleret tynde Ler- og Sandlag. Disse er stærkt forstyrrede og ødelagte og bøjede om, saa at de danner en kræmmerhusagtig Foldning (Fig. 7, S. 39). Der findes ogsaa en Overskydningsflade mellem disse Lag plus Tellinaleret og den overliggende Lagrække: Stenlaget $\mathrm{b}$, hvis største Sten er $3-5 \mathrm{~cm}$ lange, og Moræne B. Disse er ved Overskydningen blevne skubbede hen over de tynde Ler- og Sandlag og Tellinaleret i en noget anden Retning end den, hvori Tellinalerflagen er bleven skubbet op over Moræne C, hvilket fremgaar af de nedenfor anførte Maal paa denne Overskydningsflades Hældning og Strygning. Under Stenlaget og indpresset i dettes underste Del findes udtværede, tynde Lerlag, der har lettet Bevægelsen. Grænsefladen mellem, paa den ene Side, Stenlaget og de med dette følgende, tynde Lerlag under det, og, paa den anden Side, det øverste af de derunder kommende Sandlag strøg N. $5^{0} \mathrm{~V}$. og hældede $38^{\circ} \bmod \mathrm{N}$. $85^{\circ} \emptyset$. Længere mod Nordøst, paa den anden Side af Fremspringet, som dannes af Tellinalerflagen, maaltes, at Grænsefladen mellem Tellinaleret og Stenlaget strøg N. $45^{\circ} \varnothing$. og hældede $20^{\circ} \bmod$ S. $45^{\circ} \varnothing$. 


\section{Forklaring til Fig. 5 og 6.}

Fig. 5. Partierne III og IV. Den nedre Del af Klinten bestaar mod SV (til Højre) af Moræne C. Over denne, men adskilt fra den ved en Overskydningsflade, findes længst mod SV glaciofluviale Sand-, Grus- og Stenlag b og over disse Moræne B. Længere mod NØ viser der sig Tellinaler T under de glaciofluviale Lag b. Det tager til i Tykkelse nedad mod NØ og danner et næseagtigt Fremspring i Midten af Klinten. SV for dette findes der over Tellinaleret T tynde Ler- og Sandlag t, som er stærkt forstyrrede, saa at de danner en Fold, der dog ikke ses paa Billedet. Over disse Lag, men adskilte fra dem ved en Overskydningsflade, findes de glaciofluviale Sand-, Grusog Stenlag b og Moræne B. I den nordøstlige Del af Klinten ses foroven Moræne B og Stenlaget b, som kommer frem c. $8 \mathrm{~m} \mathrm{o.} \mathrm{H.} 1913$.

Fig. 6. Udgravning i den nordøstlige Del af Parti IV. I Midten af Billedet ses Tellinaleret $\mathrm{T}$, der mod $\mathrm{N} \varnothing$ bøjer sig opad, idet det bliver tyndere. Over Tellinaleret findes lyst Sand b og Moræne B, og under Tellinaleret (NØ for dette) vekslende Lag af Sand og stenfrit Ler og helt mod NØ det hvide Sand a. 1913.

\section{Explications des figures 5 et 6.}

Fig. 5. Parties III et IV. La base de la falaise consiste vers le sud-ouest (à droite), de la moraine C. Par dessus celle-ci, mais separées d'elle par une surface de charriage, se trouvent, le plus au sud-ouest, des couches glacio-fluviales b, de sable, de gravier et de pierres, et par dessus ces dernières, la moraine B. Plus loin vers le nord-est, on peut voir, sous les couches glacio-fluviales b, de l'argile à Tellina $T$, dont l'épaisseur va en augmentant vers le bas, du côté du nord-est, et produit, au milieu de la falaise, une protubérance en forme de nez. Au sud-ouest de l'endroit que nous venons de nommer, se trouve, par dessus l'argile à Tellina, de minces couches d'argile et de sable avec de fortes perturbations, qui ont donné naissance à un pli, qui, cependant, ne peut pas se voir dans l'illustration. Par dessus ces couches, mais séparées d'elles par une surface de charriage, se trouvent des couches glacio-fluviales b, de sable, de gravier et de pierres, et la moraine B. Dans la partie nord-est de la falaise, on voit, dans le haut, la moraine B, puis la couche de pierres b, qui avance d'environ $8 \mathrm{~m}$ audessus du niveau de la mer. 1913.

Fig. 6. Fouille entreprise dans la région nord-est̃ de partie IV. On aperçoit, au milieu de l'illustration, de l'argile à Tellina, qui, vers le nord-est, se recourbe en hauteur, en même temps qu'elle devient plus mince. Sur l'argile à Tellina, se trouvent du sable clair $\mathrm{b}$, et la moraine $\mathrm{B}$, et l'on voit, sous l'argile à Tellina (au nord-est de celle-ci), des couches alternantes, de sable et d'argile sans pierres, et tout à fait vers le nord-est, du sable blanc a. 1913. 


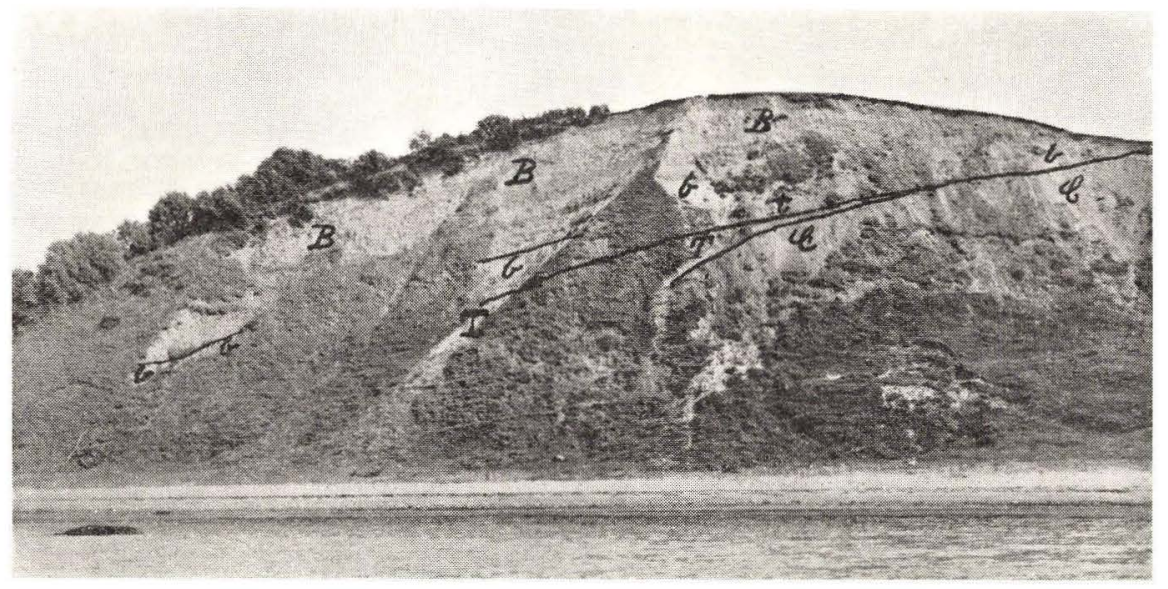

Fig. 5.

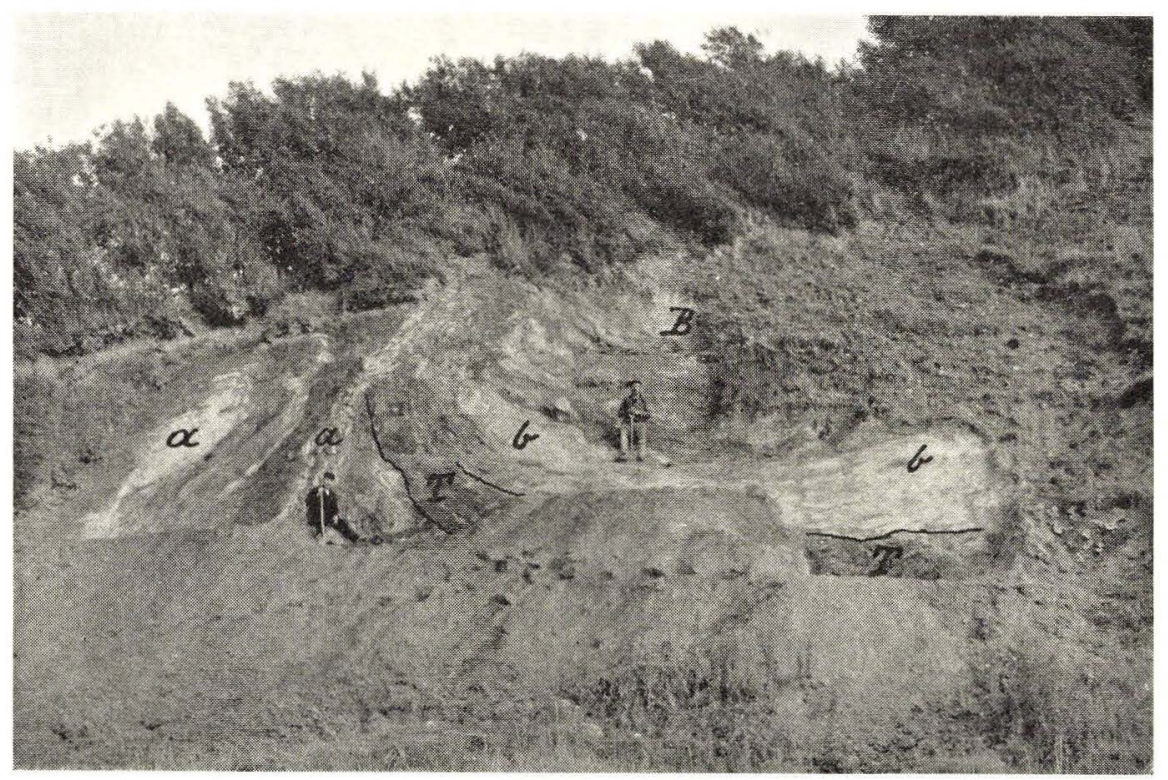

Fig. 6. 
Den større, nordøstlige Del af Parti III er for største Delen tilskredet og tildels græsbevokset. Foroven ses dog her Moræne B, der øverst er dannet af rødt og graabrunt, noget sandet Moræneler med Grussmører og derunder af Sand- og Gruslag med Bænke af graabrunt Moræneler. Det omtalte Stenlag b fortsætter sig skraat nedad mod Nordøst til en

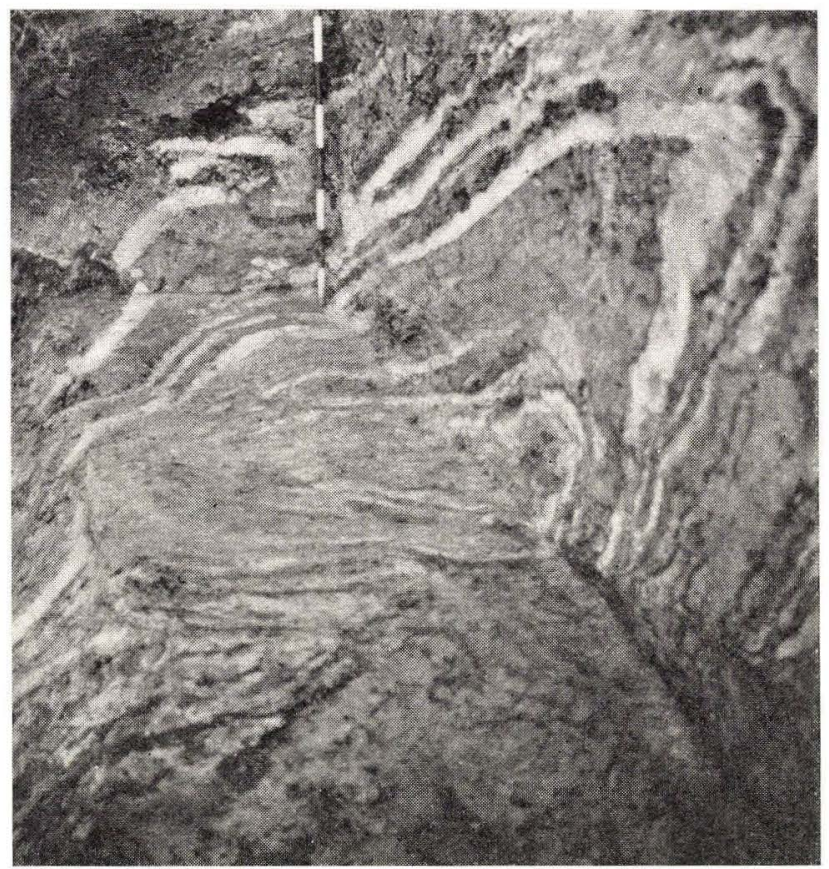

Fig. 7. Kræmmerhusformede Ler- og Sandlag t mellem Tellinaleret og Stenlaget b SV for det næseagtigt fremspringende Tellinaler i Parti III. Maalestokken er inddelt i Decimeter. 1913.

Couches d'argile et de sable $t$, en forme de cornet, se trouvant entre l'argile à Tellina et la couche de pierres b, situées au sud-ouest de l'argile à Tellina qui jaillit en forme de nez, dans la partie III. Le jalon est divisé en décimètres. 1913.

Højde over Havfladen, der kan anslaas til omtrent $8 \mathrm{~m}$. Ogsaa her ses de udtværede, tynde Lerlag under det, og under disse hvidgult Sand.

Parti IV naar mod Nordøst til det dybeste Sted i Dalen, der fra Kysten gaar op imod Gaarden Christiansminde; det er $80 \mathrm{~m}$ langt. Det er tilskredet og bevokset. Midt i Partiet, hvor vi havde Grund til at tro, at vi kunde faa Bygningen af det oplyst, foretog vi en større Udgravning (Fig. 6, S. 37). I denne stødte vi paa et Lag af sort Tellinaler, som kommer nogenlunde vandret fra Sydvest og bøjer sig opad, idet det bliver tyndere. Hvor Bøjningen begynder, er det $11_{2}^{1} \mathrm{~m}$ tykt. 
Over Tellinaleret findes lyst Sand med Smører af Moræneler og Grus. Hvad der svarer til Stenlaget i Parti III, kunde ikke afgøres med fuld Sikkerhed; rimeligvis er det repræsenteret ved et Gruslag, der findes omtrent $2 \mathrm{~m}$ over Tellinaleret, hvor dette ligger vandret, og som nærmer sig stærkt til Tellinaleret, hvor dette krummer sig opad. Stenene i Gruslaget er ærte- til ægstore, enkelte endnu større, indtil 0,7 m. Over dette Gruslag ses vekslende Bænke af lyst Sand, Moræneler og Grus, svarende til Moræne B i Parti III.

Under Tellinaleret (Nordøst for dette) findes vekslende Lag af Sand og stenfrit Ler og helt mod Nordøst hvidt Sand a, delvis rustfarvet, med tynde Lerlag. Disse Aflejringer fremtraadte i Udgravningen som stejltstaaende Lag, men følger Tellinalerets Bøjning.

Grænsen mellem det hvide Sand a og de stenfri Sand- og Lerlag er markeret ved en Stribe af smaa, tætliggende Jernkonkretioner; Grænsefladen er en mindre Dislokation. Saavel det hvide Sand som de stenfri Sand- og Lerlag afskæres udad mod Havet af en sekundær Dislokation, der omtrent har Kystens Retning, et »Lillebeltspring".

Der foretoges nogle Maalinger af Lagstillingen. Det omtalte Gruslag strøg ved den $\left.{ }^{1}\right]_{2} \mathrm{~m}$ store Sten, som ses midt i Billedet Fig. 6, N. $80^{\circ} \varnothing$. og hældede $30^{\circ} \operatorname{mod~S.~} 10^{\circ} \varnothing$.

Nordøstsiden af Tellinaleret strøg, hvor det stod stejlest, N. $60^{\circ} \mathrm{V}$. Grænsen mellem det hvide Sand og de stenfri Ler- og Sandlag strøg N. $45^{\circ} \mathrm{V}$. og hældede $65^{\circ} \bmod \mathrm{N} .45^{\circ} \varnothing$.

Den sekundære Dislokation i Kystens Retning (»Lillebeltspringet«) strøg N. $70^{\circ} \varnothing$. og hældede $65^{\circ} \bmod \mathrm{N} .20^{\circ} \mathrm{V}$.

For om muligt endnu mere detailleret at udrede Forholdene, foretoges i 1931 af Sigurd Hansen og Nordmann en ny Udgravning, idet de først opsøgte det vandret liggende Stykke af Tellinaleret, der laa i en Højde af c. $7 \mathrm{~m}$ o. H. Derefter fulgtes det mod $\mathrm{N} \varnothing$ opadgaaende Tellinaler, idet dette og dets Omgivelser blottedes i en Højde fra 8,35 til c. $12{ }^{1} / 2$ m o. H. Her tværedes det ud og opløstes i Lerbrokker blandede med Klumper af Sidemassernes Sand; muligvis er det ovenfor liggende dog Ras.

I c. 17 m's Højde sidder der mod Vest i Gruslaget en stor Sten, hvis største synlige Diameter er 0,7 m, men forøvrigt findes der paa Grænsen mellem Tellinalerets Overflade og det ovenover (altsaa her Vest for) liggende Sand b en Del Grus, hist og her samlet i Klumper og delvis nedpresset i Tellinaleret.

Tellinaleret danner en Bue med Konveksiteten vendende mod Nordøst. Dens Form kan angives ved følgende Strygninger og Hældninger, tagne paa Tellinalerets Undersgrænse, som — skønt meget ujævn dog var den bedst bevarede og regelmæssigste: 
c. $8,5 \mathrm{~m} \mathrm{o.H}$. Strygning N. $55^{\circ} \mathrm{V}$. Hældning $76^{\circ} \bmod \mathrm{S} .35^{\circ} \mathrm{V}$.

c. $9,5 \mathrm{~m} \mathrm{o}$. H. Strygning N. $22^{\circ} \mathrm{V}$. Hældning c. $87^{\circ} \bmod \mathrm{S} .67^{\circ} \mathrm{V}$.

$10,4 \mathrm{~m} \mathrm{o}$. H. Strygning N. $59^{\circ} \mathrm{V}$. Hældning $64^{\circ} \bmod \mathrm{N} .31^{\circ} \mathrm{V}$. $12,5 \mathrm{~m} \mathrm{o}$. H. Strygning N. $30^{\circ} \mathrm{V}$. Hældning $40^{\circ} \bmod$ N. $60^{\circ} \mathrm{V}$.

Som ovenfor sagt er Tellinalerets Underkant meget uregelmæssig. Sandklumper og Linser findes i Lerets nedre Del, og tynde Lerlag synes at bue ud fra Underkanten ( eller mindre løsrevne fra den, navnlig mellem 9,5 og $10,5 \mathrm{~m} \mathrm{o}$. H. I nogen Afstand $\mathrm{N} \varnothing$ for den (= nedenfor den) ses to større Buer eller Smører af Ler blandet med Sandsmører og Klumper og nogenlunde konforme med Tellinalerets Underkant i Henseende til Krumning. Umiddelbart Øst for den østligste Bue kommer Hovedmassen af det hvide Sand a. Mellemrummene mellem Buerne er hovedsagelig fyldte med Sand, dog stedvis saa fyldt med Lerbrokker og smaa Smører, at Lerbuerne næsten flyder sammen, og deres Grænser er vanskelige at bestemme.

Parti V er 190 m langt. Det naar mod Sydvest til det dybeste Sted i Dalen, der fra Kysten gaar op imod Gaarden Christiansminde. Mod Nordøst gaar det til et ikke videre udpræget Fremspring, som vi ved vore Udgravninger har benævnt $\mathrm{Nr}$. 11. Klinten hæver sig paa denne Strækning - NØ for Christiansminde-Dalen — til en Højde af $37 \mathrm{~m}$. Ved Hovedundersøgelserne i 1913-14 var de sydvestlige $100 \mathrm{~m}$ stærkt tilskredne og græsbevoksede, saa vi kun ved dels at undersøge de enkelte ubevoksede Pletter, dels ved at foretage en Del Smaagravninger kunde faa et Indblik i Klintens Bygning. Herved konstaterede vi, at der i den sydvestlige Del, langs med den mod NØ løbende Nedgang fra Christiansminde-Dalen til Stranden forekommer sekundære Dislokationer (»Lillebeltspring«) omtrent i Kystens Retning, ved hvilke Tellinaleret er sunket noget i Forhold til det underliggende, hvide Sand, som derved kommer til at ligge bag ved Tellinaleret, inde i Klinten. I en af disse Udgravninger, der foretoges $9 \mathrm{~m}$ over Havfladen $55 \mathrm{~m}$ Nordøst for Dalbunden, maaltes Dislokationsfladen mellem Tellinaleret og det "underliggende« Sand, som saas i Hullets Bagvæg; den strøg N. $25^{\circ} \varnothing$. og hældede $80^{\circ} \bmod \mathrm{S} .65^{\circ} \varnothing$. I denne Udgravning saas af Tellinaleret kun dets nederste Afdeling, som bestaar af tynde Sand- og Lerlag af lysegraa Farve. Disse Lag afskæres skraat af Grænsefladen mod Sandet. Længere mod Sydvest i de andre Udgravninger, som ligger $6-8 \mathrm{~m}$ over Havfladen (langs den ovenomtalte Nedgang), er Dislokationernes Strygning og Hældning noget anderledes. Her ses en højere Afdeling af Tellinaleret, federe sort Ler med underordnede, rødgule Sandlag. 
Længere mod NØ i dette Parti dannes den øverste Halvdel af Klinten af Tellinaler, der kommer til Syne i de omtalte, ubevoksede Pletter, samt i et støre Skred. Helt foroven er Tellinaleret stærkt forvitret $\mathrm{og}$ af en lys, brunlig Farve. I omtrent $3 / 4$ af Klintens Højde fandtes i graat Tellinaler Skaller af Tellina calcarea og Saxicava arctica.

I Klintens halve Højde foretoges en lidt større Udgravning, hvorved Tellinalerets Underkant blottedes. Denne viste sig at ligge omtrent $15 \mathrm{~m}$ over Havet. Det udgravede Profil var $1 \frac{1}{1} / 2 \mathrm{~m}$ højt og viste foroven Tellinalerets nedre Afdeling, tynde Ler- og Sandlag, og derunder hvidt Sand a. Som vi straks skal se, er der sket en Forskydning mellem Tellinaleret og Sandet. I Tellinaleret er Lerlagene overvejende; deres Farve er lysegraa. I Sandet er de øverste 3-4 dm rent, hvidt Kvartssand, men derunder optræder der i det talrige, ganske tynde Lerlag, dog saaledes, at Sandet stadig er overvejende. I den nedre Del af det rene Sand ses større og mindre, skarpkantede Brokker og Blokke af Tellinalerets tynde Sand- og Lerlag, og dette i Forening med, at der er en skarp Grænse mellem Tellinaleret og det rene Sand, viser, at her ikke findes en normal Paalejring, men den øverste Del af Sandet er en Breccie, som er opstaaet ved, at Tellinaleret er blevet forskudt i vandret Retning over Sandet.

Begge Aflejringer er desuden gennemsatte af mindre Spring, saa vel lodrette som skraa og vandrette. (Se Slutningen af dette Afsnit S. 52). Disse Spring danner i Tellinaleret Veje for Vandtrækket, og i Fortsættelse af dem findes i Sandet Jernudskillelser; der endog et Sted har dannet en stor, af Rust sammenkittet Sandklump i det rene, hvide Sand. Paa Grund af disse Spring ligger Tellinalerets Underflade ikke i samme Niveau over hele Profilet.

Hinsides det omtalte Skred i den nordøstlige Halvdel af Parti V, naar Klinten sin største Højde $37 \mathrm{~m}$. Klinten er for største Delen tilskredet, men ubevokset. Kun foroven staar nogenlunde rene Vægge, som hovedsagelig dannes af Tellinaler, der overlejres af Stenlaget b og den derover liggende Moræne B. Det vil fremgaa af det følgende, at Stenlaget $\mathrm{b}$ er adskilt fra Tellinaleret ved en Overskydning (Fig. 8, S. 45 og Fig. 14, S. 59).

I det ovenfor omtalte Skred ses næsten udelukkende Tellinaler, der i den sydvestlige Del af Skredet gaar helt op til Markens Overflade. I den nordøstlige Del af Skredet ses Stenlaget b, der midt i Skredet naar op til Overfladen. Herfra toges med Øjemaal Lagets Strygning N. $85^{\circ} \mathrm{V}$. og Hældning $20^{\circ} \bmod$ N. $5^{\circ} \varnothing$.

Ved Udgravninger i den Del af Partiet, som ligger Nordøst for Skredet, og som hovedsagelig indtages af Tellinaler, har vi overbevist os 
om, at dette tilsyneladende har større Mægtighed, end det i Virkeligheden har, idet det dels hælder udad mod Kysten og dels er bleven presset sammen og foldet.

Den sydvestligste og laveste Udgravning Nr. 1, Fig. 9, S. 45, gjordes nicheformig; den foretoges c. $10 \mathrm{~m}$ over Havet, var $2 \mathrm{~m}$ bred, $2 \mathrm{~m}$ dyb og $3 \mathrm{~m}$ høj. Nederst fandtes tilsyneladende uforstyrret Sand a, i hvilket der gravedes $1 \mathrm{~m}$ ned. Sandet indeholder Smaasten, Lerrullesten, rullede Stykker af Konkretioner fra det Plastiske Ler og Kulstumper, der var indtil $15 \mathrm{~cm}$ lange. Som det senere skal blive begrundet, maa dette Sand opfattes som Tellinalerets »Liggende» a. Det gaar ned til Stranden bag ved Skredene og kommer til Syne, efterhaanden som disse vaskes bort af Havet. Det danner i Virkeligheden den nederste Del af Klinten over det meste af Partiet. Sandets Overflade er uregelmæssig. Over Sandet fandtes c. $1 \mathrm{~m}$ Breccie: kantede Brokker af Sand og fint Grus af forskellig Finhed og Lagstilling (overvejende foroven), og skarpkantede Stykker af de tynde Sand- og Lerlag, som danner Tellinalerets nedre Del (overvejende forneden). Disse Tellinaler-Stykker var fra nøddestore til hovedstore og mere. Lagstillingen var forskellig i de forskellige Stykker. Derover blottedes c. $1 \mathrm{~m}$ af Tellinalerets nederste Del, de tynde Sand- og Lerlag med Rustlag. Midt i Nichen viste der sig et kileformigt Parti, begrænset paa begge Sider af Spring; Kilen var dannet af Brokker af Tellinaler, omgivne af Sand. I Nichens nordøstlige Side strøg Tellinalerets Underflade N. $80^{\circ} \mathrm{V}$. og hældede $25^{\circ}$ $\bmod N .10^{\circ} \varnothing$., medens den i Nichens sydvestlige Side strøg N. $70^{\circ} \varnothing$. og hældede $10^{\circ} \bmod$ N. $20^{\circ} \mathrm{V}$. Man ser saaledes, at Tellinaleret er forskudt i Forhold til det underliggende Sand, ligesom i den Del af Parti $\mathrm{V}$, der ligger Sydvest herfor.

I Fortsættelse af Nichens nederste Del gravedes videre mod Nordøst, hvorved der ved Siden af Nichen fremkom et $4 \mathrm{~m}$ langt og 1,7 m højt Profil. I dette saas Sandet a, dækket af de tynde Sand- og Lerlag, som danner Tellinalerets nedre Del; disse bøjede sig nedad mod Nordøst.

Højere oppe i Klinten, c. $20 \mathrm{~m}$ over Havoverfladen foretoges en større Udgravning Nr. 2, 9,2 m lang og 1,4 m høj; i dens sydvestlige Ende udgravedes en 2,2 $\mathrm{m}$ høj Niche og under denne lodret ned ad Klintens Skraaning en Grøft, saa at der her i det hele fremkom et Profil, som var $6 \mathrm{~m}$ højt. Den nederste Afsats i Grøften var 2,5 $\mathrm{m}$ lang og 1,6 $\mathrm{m}$ høj; den viste vekslende Lag af Tellinaler og underordnede, tynde Sandlag, gennemsatte af skraa og vandrette, sandfyldte Springrevner. I Leret var der udskilt meget Gibs. Lagenes Hældning var $20-30^{\circ} \bmod N$. og Strygningen omtrent Ø.-V. I Grøftens øverste Afsats, der var $3,3 \mathrm{~m}$ lang i vandret Retning, var Bunden skraa. Forneden i Afsatsen var Lagene af Tellinaler og Sand omtrent lige tykke, 


\section{Forklaring til Fig. 8 og 9 .}

Fig. 8. Den nordøstlige Del af Parti V. Over og under de nedskredne Masser ses Tellinaler $\mathrm{T}$, som er overlejret af Stenlaget $\mathrm{b}$, af Sand $\mathrm{b}$ og af Moræne B. Mellem Stenlaget og Tellinaleret er der en Overskydningsflade. 1913.

Fig. 9. De i Teksten omtalte 5 Udgravninger i den nordøstlige Del af Parti V. Forneden til Højre i Gravning Nr. 1 ses Sandet a overlejret af Tellinalerets nederste Del. Højere oppe i Nr. 2 ses vekslende Lag af Tellinaler og Sand gennemsat af Spring, i Nr. 3, foroven til Venstre, Tellinaler med underordnede Sandlag, i Nr. 4, længere til Højre, Lag af Ler og Sand overlejret af fedt Tellinaler, foldet som en Plissé, og derover en Saddel af Sandog Lerlag, og endelig, længst til Højre, i Nr. 5 Tellinaler med Sandlag. Helt foroven til Venstre i Billedet ses Moræne C over Moræne B i Bagvæggen i det sydvestlige Fald i Parti VI. 1914. Fig. 13, S. 53, viser, hvorledes denne Del af Klinten saa ud i 1931.

\section{Explications des figures 8 et 9 .}

Fig. 8. La section nord-est de partie V. Au-dessus et au-dessous des éboulis, se trouve de l'argile à Tellina T. qui est superposée par la couche de pierres b, par le sable b et la moraine B. Entre la couche de pierres et l'argile à Tellina, se trouve une surface de charriage. 1913.

Fig. 9. Les 5 fouilles entreprises dans la section nord-est de partie V, et décrites dans le texte. En bas à droite, dans la fouille no. 1, on voit le sable a, recouvert par la partie la plus basse de l'argile à Tellina. Plus haut, dans no. 2, on voit des couches alternantes d'argile à Tellina et de sable, traversées de failles. Dans no. 3, en haut à gauche, de l'argile à Tellina, avec des couches de sable d'ordre secondaire. Dans no. 4, plus loin à droite, se trouvent des couches d'argile et de sable, superposées d'argile grasse à Tellina, pliée en plissement, par dessus lequel se trouvent, en dos d'âne, des couches de sable et d'argile, et, enfin, le plus à droite dans no. 5, de

l'argile à Tellina avec des couches de sable. Tout en haut à gauche dans l'illustration, on voit, dans la paroi postérieure de la descente la plus au sud-ouest dans partie VI, la moraine C au dessus de la moraine B. 1914. Fig. 13, p. 53, démontre quelle était l'apparence de cette section de la falaise, en 1931. 


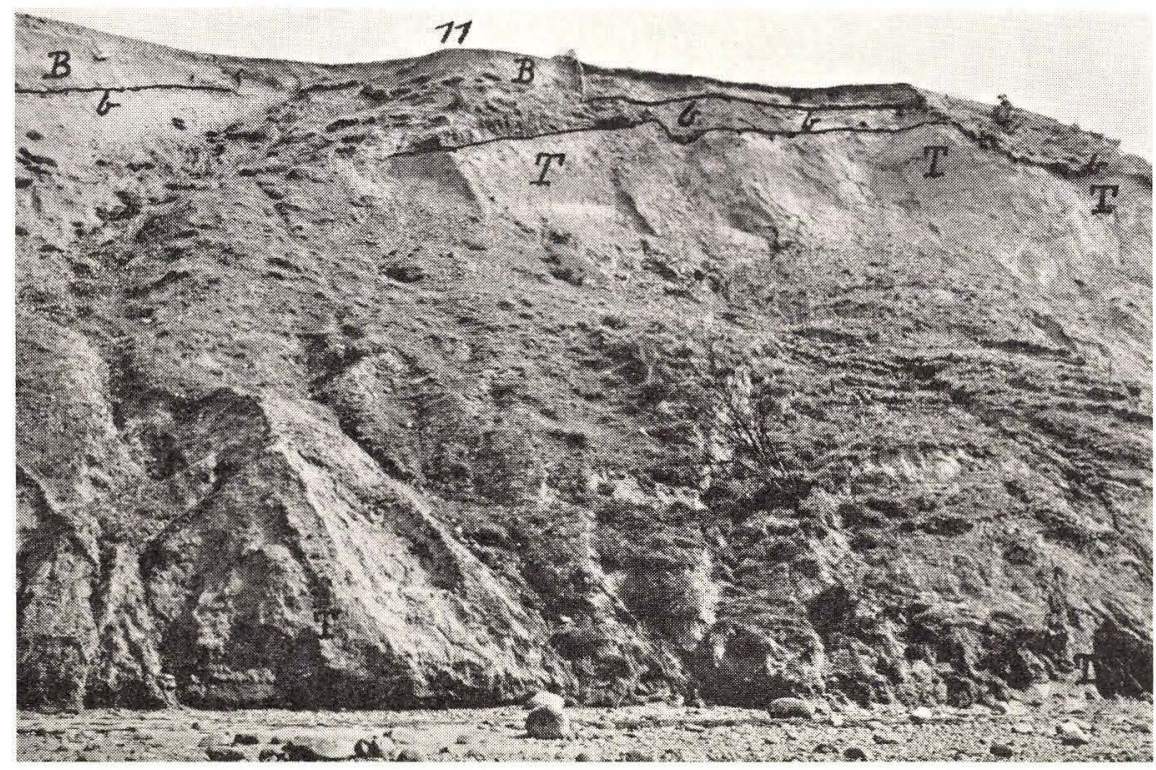

Fig. 8 .

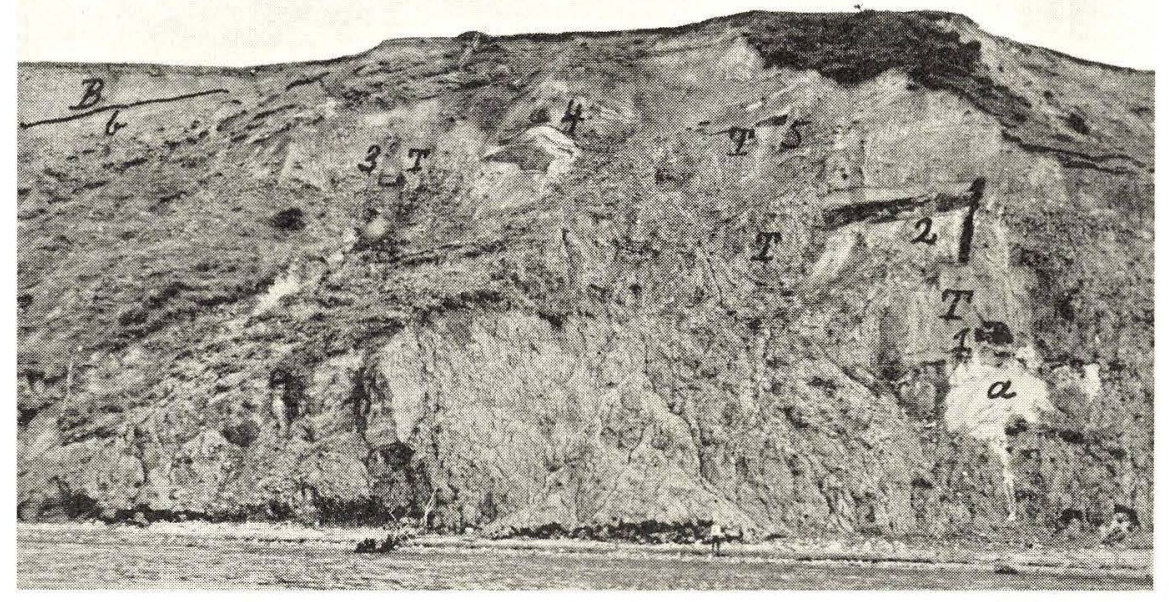

Fig. 9. 
$2-3 \mathrm{~cm}$; foroven i Afsatsen blev Sandlagene $6 \mathrm{~cm}$ tykke og Lerlagene $3 \mathrm{~cm}$ tykke. Forneden i Nichen kulminerede Sandlagenes Tykkelse med et $40 \mathrm{~cm}$ tykt Lag.

I Væggen i selve Udgravningen saas en Mængde Spring, dels skraa og dels næsten vandrette. I Midten fandtes et kileformigt Stykke, fyldt med en Breccie af skarpkantede Lerklumper og Sand (Fig. 10, S. 49). Den øvrige Del af Profilet var ved Spring delt i større og mindre Dele, indenfor hvilke Lagdelingen var nogenlunde vandret og uforstyrret. Alle Vegne kunde man iagttage, at Sandlagene opad tiltog i Mægtighed til det omtalte, $40 \mathrm{~cm}$ tykke Lag, som indeholder underordnede brune Lag med ringe Lerindhold, og som er fyldt med Ler-Brokker. I den øverste Del af Profilet var Sandlagene underordnede, og fede Lerlag dominerende. Spring-Spalterne udvidede sig uregelmæssigt og var fyldte med Sand.

Omtrent $160 \mathrm{~m}$ fra Partiets Sydvestende foretoges i Klintens øvre Del tre Udgravninger ved Siden af hinanden i ringe indbyrdes Afstand.

Mod Nordøst gravedes et Profil Nr. 3, 1,5 m bredt og $7 \mathrm{~m}$ højt. Der fandtes Tellinaler med underordnede tynde Sandlag. Disse var noget mere fremtrædende c. $2 \mathrm{~m}$ og c. $5 \mathrm{~m}$ under Udgravningens Overkant. Lagstillingen var vekslende, hældende ud mod Lillebelt, stejlest i Midten af Profilet.

Lidt længere mod Sydvest, c. $25 \mathrm{~m}$ over Havfladen udgravedes et Profil Nr. 4, $6 \mathrm{~m}$ langt og i Midten $5 \mathrm{~m}$ højt. Forneden saas svagt buede og saa temmelig uforstyrrede Lag af Ler og Sand; det øverste af Sandlagene, som oversteg de underliggende betydeligt i Mægtighed, var $15 \mathrm{~cm}$ tykt; det dannede en Fortsættelse af det Sandlag, som fandtes i den forrige Udgravning $5 \mathrm{~m}$ under dennes Overkant. Over Sandlaget bestod Væggen hovedsagelig af fedt Tellinaler med meget tynde Sandlag. Disse fremtraadte i Midten af Profilet som en lodret staaende Plissé (Fig. 11, S. 49); ogsaa paa Siderne af denne var Lagene stærkt sammenpressede og foldede. Over Plisseen som Kærne var der en stor Fold (Saddel) af Sand- og Lerlag, der var tykkest i Foldens Ryg og tyndere nedad Kærnens Sider. Et af de øverste Sandlag var en $6 \mathrm{~cm}$ mægtigt og indeholdt et Lag af tætliggende, mindre Lerbrokker. Dette Brokkelag forsvandt i Siderne af Udgravningen. Derunder vekslede tynde, lerede, mørke Sandlag med tykkere Lag af renere Sand. Det hele var gennemsat af mange Smaaspring. Over Folden saas Tellinaler med meget underordnede Sandlag.

Endnu længere mod Sydvest gravedes et Profil Nr. 5, $6 \mathrm{~m}$ langt og $2 \mathrm{~m}$ højt. Det viste øverst Tellinaler med underordnede Sandlag og Skaller af Tellina og Saxicava. Længere nede blev Sandlagene dominerende, dog blev helt forneden mod Sydvest Ler atter fremherskende. I Sydvestenden af Udgravningen dannede Lagene en Saddel til, og Syd- 


\section{Forklaring til Fig. $10 \mathrm{og} 11$.}

Fig. 10. Detailbillede af Gravning Nr. 2 i den nordøstlige Del af Parti V. Tellinaler og Sand gennmesat af Spring. Maalestokken er inddelt i Decimeter. 1914.

Fig. 11. Detailbillede af Gravning Nr. 4 i den nordøstlige Del af Parti V. Forneden ses svagt buede Lag af Sand og Ler, over disse fedt Tellinaler med meget tynde Sandlag, foldede som en Plissé, og derover en Fold af Sand- og Lerlag. Maalestokken er inddelt i Decimeter. 1914.

\section{Explications des figures 10 et 11.}

Fig. 10. Illustration des détails du fouille no. 2, dans la section nord-est de partie V. Argile à Tellina et sable, traversés de failles. Le jalon est divisé en décimètres. 1914.

Fig. 11. Illustration des détails du fouille no. 4, dans la section nord-est de partie V. En bas, on voit des couches de sable et d'argile légèrement courbes, sur lesquelles se trouve l'argile grasse à Tellina, contenant de très minces couches de sable, pliées en plissement, et par dessus celles-ci, un pli de couches de sable et d'argile. Le jalon est divisé en décimètres. 1914. 


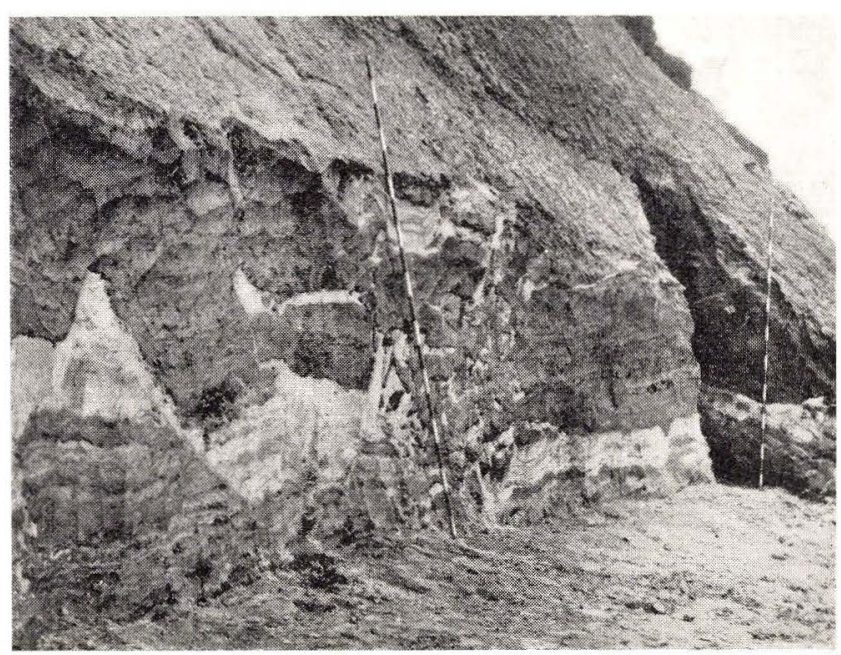

Fig. 10.

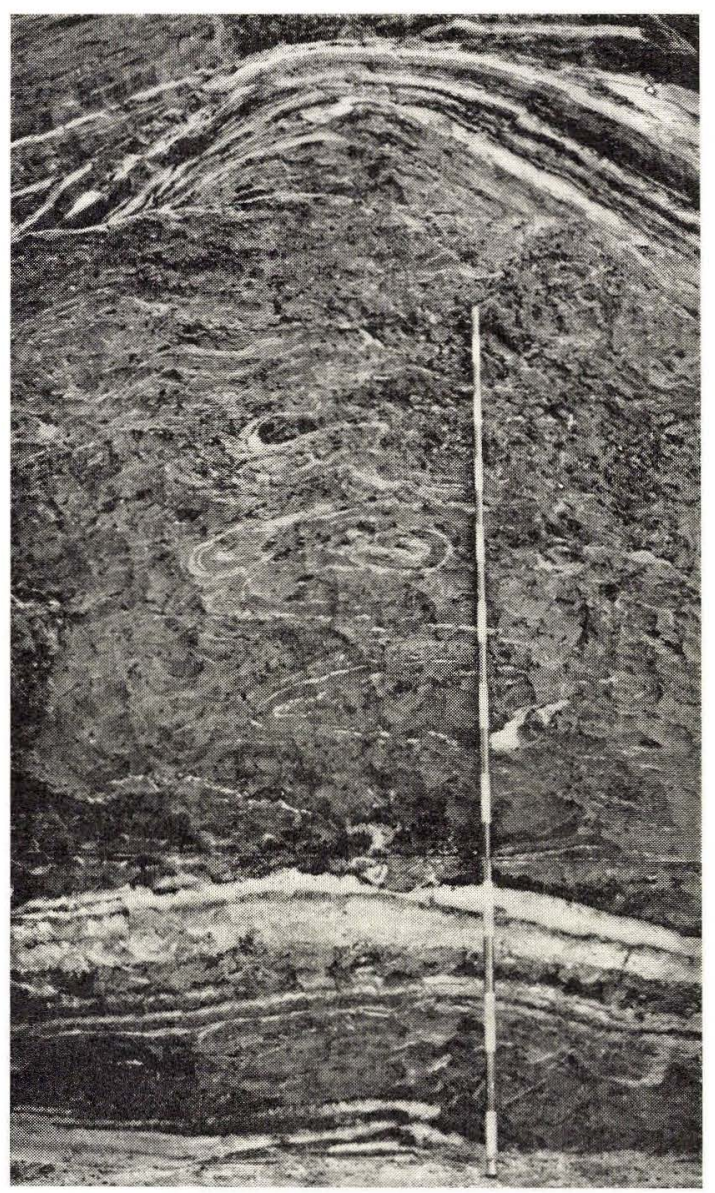

Fig. 11. 
vest for Udgravningen, hvor Væggen rensedes, gik Lagene atter opad for at danne en tredje Saddel. I Truget mellem disse to Sadler er Sand fremherskende foroven, medens der i Bunden ses Bænke af fedt Tellinaler.

Spørgsmaalet, om disse 5 Udgravninger er gjorte i en sammenhængende Lagrække, eller om flere Flager af Tellinaler er skubbede op over

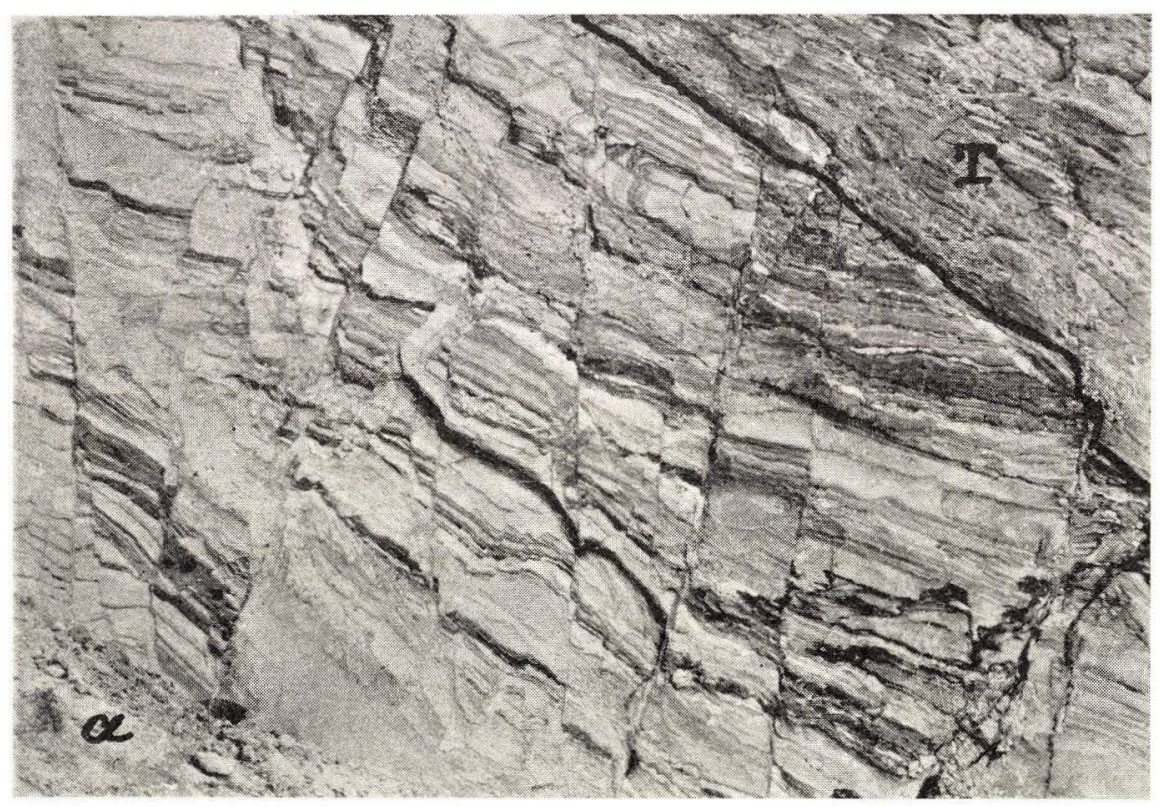

Fig. 12. Parti V. Det mod Nord vendende Profil i den nedgledne Tellinalerflage umiddelbart Nordøst for Christiansminde-Dalen. Foroven til Højre ses Tellinaleret T, derunder de tynde Sand- og Lerlag gennemsatte af talrige, hovedsagelig lodrette Spring. Helt forneden til Venstre ses det hvide Sand a. V. Nondmans fot. 1931.

Partie V. Le profil orienté vers le nord, se trouvant dans le morceau éboulé d'argile à Tellina, et situé directement au nord-est de la vallée de Christiansminde. En haut à droite, on voit l'argile à Tellina $\mathrm{T}$, et dessous, les minces couches de sable et d'argile, traversées par de nombreuses failles, principalement verticales. Tout en bas, à gauche, se trouve le sable blanc a. V. Nordmann phot. 1931.

hverandre, kunde ikke afgøres med Sikkerhed; dog er det første Alternativ det sandsynligste. I hvert Tilfælde er der sket en stærk Sammenpresning, der har bevirket, at Tellinaleret har faaet langt større Mægtighed, end det oprindelig har haft.

(Af V. Norduann). Den Forestilling, vi havde dannet os om Klintens Bygning i dette Parti, fik sin Bekræftelse ved de supplerende Undersøgelser, som i 1931 blev foretagne af V. Nordmann med Assistance af Sigurd Hansen. I de 17 Aar, der var forløbet siden Afslutningen af Hovedundersøgelsen, var Klinten Nordøst for Christiansminde-Dalen 
bleven blottet mere og mere, saa at den næsten stod nøgen i hele sin Højde. Som Udgangspunkt for Klintens Opmaaling valgtes — som tidligere - et Punkt paa Strandbredden udfor det Sted, hvor Christiansminde-Dalens Bund ved sin Udmunding i Klinten ligger lavest.

Ved Østenden af det Side 41 omtalte nedsunkne Tellinalersparti har der i Tidens Løb dannet sig et lille Profil, som vel gaar jævnt over i de større Profiler NØ derfor, men som dog har en anden Retning end disse; medens Klintefladen med disse Profiler løber NØ-SV, vender det omtalte, lille Profil mod Nord. (Fig. 12). I Profilet ses den nedskredne Tellinalerflages Undergrænse som en (paa Grund af talrige Spring) zigzagformet Linje, der fra oven til venstre (d. v. s. mod Øst) løber skraat nedad til højre (mod Vest). Under denne Grænse ses et »Overgangslag« af vekslende Sand-og Lerlag og derunder det rent hvide Sand a. Overgangslaget er i særlig Grad gennemsat af talrige, savel lodrette som skraa og vandrette Spring, der minder om »Scherflächen« i en Gletjervæg.

Tellinalerflagen fremtræder da her i Profilet som et kileformet Parti, forneden begrænset af den omtalte, zigzagformede Skraalinje, foroven af Kanten af den tildels bevoksede Klintflade, der vender mod Havet $(\bmod N V)$. Denne Kiles $\bmod \varnothing_{\text {st }}$ opadvendende Spids ligger c. $7^{1 / 2} \mathrm{~m}$ o. H. og $59 \mathrm{~m} \mathrm{NV}$ for det valgte O-Punkt paa Strandbredden udfor Christiansminde-Dalen. Grænsefladen mellem Tellinalerflagen og de vekslende, tynde Sand- og Lerlag stryger her N. $2^{\circ} \varnothing$., og Hældningen er $70^{\circ} \bmod \varnothing .2^{\circ} \mathrm{S}$., men denne Hældning er altsaa ikke den normale »Overskydning«, men et stejlt Spring (»Lillebeltspring«).

Omtrent midtvejs i Profilet stryger Grænsefladen N. $4^{0} \varnothing$. og hælder $38^{\circ} \bmod$ N. $86^{\circ} \mathrm{V}$. Tellinalerflagens egen Lagstilling er omtrent den samme. 6,5 nærmere mod O-Punktet (altsaa i den delvis tilvoksede, $\bmod$ NV. vendende Klintflade) stryger de rustfarvede Sandlag, som angiver Tellinalerets Lagstilling, ligeledes N. $4^{\circ} \varnothing$., men hælder kun $30^{\circ} \bmod$ N. $86^{\circ} \mathrm{V}$. Undergrænsen mod »Overgangszonen" og det hvide Sand kan ikke ses her saa lidt som paa det følgende Observationssted, da den ligger et godt Stykke inde i Klinten. 4,5 m endnu længere mod SV. (altsaa $48 \mathrm{~m}$ NØ. for O-Punktet) stryger Sandlagene N. $7^{\circ} \varnothing$. og har en Hældning af $25^{\circ} \bmod$ N. $83^{\circ} \mathrm{V}$.

Det omtalte "Overgangslag« med de talrige Spring og Smaaforskydninger fortsætter sig mod NØ. over det hvide Sand a, som - for Størstedelen tilskredet - danner den nederste Del af Klinten paa Strækningen mellem c. 60 til $140 \mathrm{~m}$ nordøst for O-Punktet (Fig. 13, S. 53). Det hvide Sand er af meget vekslende Kornstørrelse, omend Hovedmassen er ret finkornet og skarp. Fra Østenden af den nedskredne Tellinalerflage og hen under Tellinaleret foroven i Klinten ses foroven i Sandet en Del opadbuede Gruslag med nødde- til omtrent hovedstore 


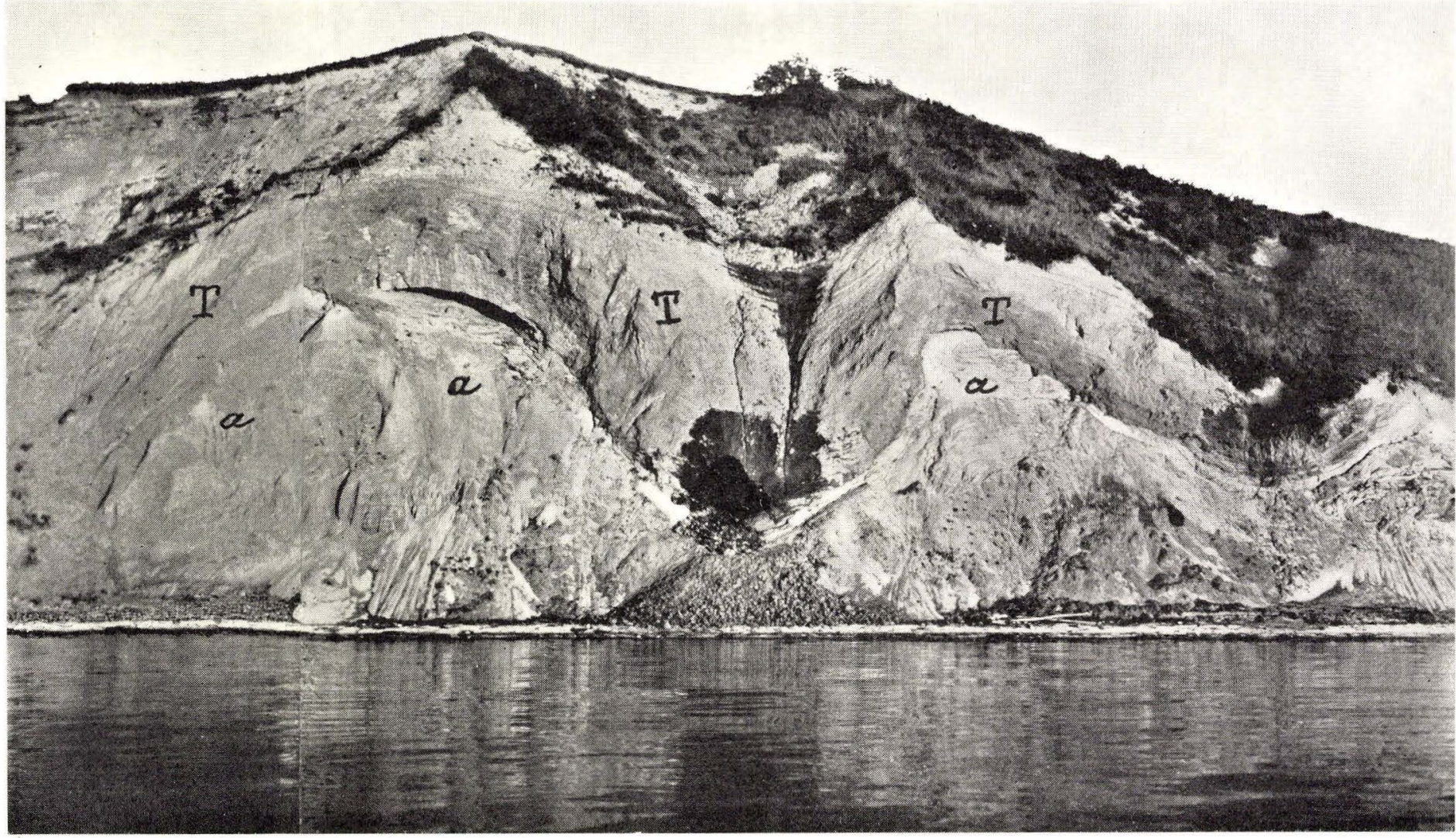

Fig. 13. Den nordøstlige Del af Parti V. Tellinaleret med dets underordnede Sandlag hviler paa et »Overgangslag« af tynde Sand- og Lerlag, som hviler paa det hvide Sand a. Lagene danner 3 Sadler og 2 mellemliggende Truge. Siguri) Hansen fot. 1931.

La section nord-est de partie V. L'argile à Tellina avec ses couches de sable d'ordre secondaire, repose sur une »couche de transition de minces couches de sable et d'argile, qui reposent sur le sable blanc a. Les couches forment 3 anticlinaux et 2 synclinaux intermédiaires. Sigurd HansEN phot. 1931. 
Sten; disse Gruslag er synlige over den tilskredne Del i en samlet Mægtighed af c. $1^{1 / 2} \mathrm{~m}$; længere mod Nordvest bliver det mere finkornet.

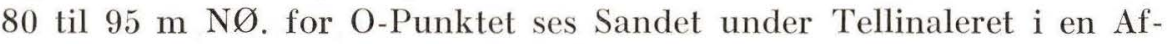
stand af $1 /_{2}-11_{2} \mathrm{~m}$ fra dettes Underflade at indeholde tynde Lerlag eller lerede Sandlag; det er tydelig lagdelt helt ned til de nedskredne Masser, og den nederste synlige Del ovenfor disse indeholder tynde Gruslag. Grænsen mod det overliggende Tellinaler er, som det senere skal beskrives, ujævn med to store Buer eller Folder, og de nys skildrede Egenskaber ved Sandet gælder Partiet i den Bue, der er nærmest 0-Punktet; hvor Sandet atter hæver sig i den næste Bue, er det ret finkornet og viser en tydelig, men kun svagt discordant Lagdeling. Længere mod NØ., hvor Grænsen mod Tellinaleret atter sænker sig mellem 124 og $144 \mathrm{~m}$ NØ. for 0-Punktet, — maa Sandet nærmest kaldes Grus med nødde- til hovedstore Sten og uden tydelig eller kun med meget utydelig Lagdeling.

Ovenpaa dette Sandlag hviler, som det tidligere er skildret, Tellinaleret, der danner den øverste Del af Klinten paa Strækningen mellem c. $50 \mathrm{og}$ c. $140 \mathrm{~m}$ Nordøst for 0-Punktet. Ved Undersøgelsen i 1931 var det i det store og hele utilgængeligt, og de Forstyrrelser og Foldninger i det, som var iagttagne i 1913-14, kunde ikke længere undersøges. I den sydvestlige Ende af det, mellem 50 og $70 \mathrm{~m}$ nordøst for O-Punktet, er Klinten endnu græsbevokset fra Overkanten (som skraaner ned mod Christiansminde-Dalen) og ned til c. $13^{1} / 2$ m's Højde o. H.; her kan man altsaa - ligesom tidligere - paavise Tellinalerets Underflade ved Gravninger; den er forøvrigt ikke let at bestemme nøjagtig, fordi der her synes at være en jævn Overgang mellem Tellinaleret og

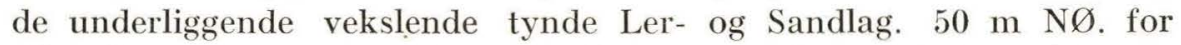
0-Punktet og tret ved Klintens nedadskraanende Rand ligger Tellinalerets Underflade c. $16,5 \mathrm{~m}$ o. H. $74 \mathrm{~m}$ NØ. for 0-Punktet sænker Grænsefladen mod det underliggende hvide Sand a sig, indtil den c. $80 \mathrm{~m}$ NØ. for 0-Punktet er $8,2 \mathrm{~m}$ o. H. Flere Meter til begge Sider for dette Sted viser den sig som en flad, nedadvendende Bue. Mod NØ. hæver Grænsefladen sig paany; i c. 14 m's Højde o. H. stryger Tellinalerets Underflade N. $10^{\circ} \mathrm{V} . \mathrm{og}$ hælder $39^{\circ} \bmod \mathrm{V} \cdot 10^{\circ} \mathrm{S}$., medens selve Lagene i Tellinaleret stryger N. $14^{\circ} \mathrm{V}$. og hælder $36^{\circ} \bmod \mathrm{V} .14^{0}$ S. Efter at Grænsefladens Hældning paa en Strækning af $11^{1} / 2 \mathrm{~m}$ er bleven betydelig svagere, saaledes at den omtrent $92 \mathrm{~m} \mathrm{N \varnothing}$. for 0-Punktet ligger 14,7 m o. H., stiger den hurtigt i Vejret paa en Strækning af omtrent $1 \mathrm{~m}$ til en Højde af c. $16 \mathrm{~m}$. Denne opadstigende Del af Grænsefladen stryger N. $42^{\circ} \mathrm{V}$. og hælder $58{ }^{\circ} \bmod \mathrm{V} .42^{\circ} \mathrm{S}$, medens Tellinalerets Lag stryger N. $30^{\circ} \mathrm{V}$. og hælder $14^{\circ}-16^{\circ} \bmod \mathrm{V}$. $30^{\circ} \mathrm{S}$. Efter at Grænsefladen nu i en Længde af omtrent $11_{2} \mathrm{~m}$ er for- 
løbet temmelig vandret, stiger den atter i Løbet af en halv Meter til godt 17 m's Højde, for saa atter at løbe vandret i godt 2 m's Længde, hvorpaa den atter sænker sig, først (paa Grund af smaa Spring) som en Zigzaglinje, dernæst efter en temmelig lodret Linje ned til en Højde af omtrent $14 \mathrm{~m} \mathrm{o}$. H. Strygningen paa dette Sted var N. $58^{\circ} \mathrm{V}$. og Hældningen $77^{\circ} \bmod$ V. $58^{\circ} \mathrm{S}$. Tellinalerets Lagdeling strøg N. $42^{0} \mathrm{~V}$. og hældede c. $38^{\circ} \bmod N .48^{\circ} \varnothing$.

Grænsefladen fortsætter sig nedad i skraa Retning mod NØ.; 102,5 m NØ. for 0-Punktet maaltes dens Hældning og Strygning 7,5 m o. H.; den strøg N. $58^{\circ}$ V. og hældede c. $25^{\circ} \operatorname{imod}$ N. $32^{\circ} \varnothing$. Tellinalerets Underflade danner paany en nedadgaaende Bue, hvis dybest liggende Punkt ligger c. 108,5 m NØ. for 0-Punktet og i en Højde af c. $6 \mathrm{~m}$ o. H. Herfra gaar Grænsefladen atter opad mod NØ., i Begyndelsen forholdsvis skraat, men efterhaanden nærmende sig til den vandrette Linje, indtil den naar sit højeste Punkt, c. $19 \mathrm{~m}$ o. H., $127 \mathrm{~m}$ NØ. for 0-Punktet. Her er Tellinaleret underhulet ved det hvide Sands Udskridning, og et Parti af Lerets nederste Del er styrtet ned.

Den nys omtalte, nedadvendende Bue af Tellinaleret omsluttes af et underliggende »Overgangslag « af vekslende tynde Sand- og Lerlag Dette Overgangslag er stærkt gennemsat af Spring, saa det frembyder Udseende af en Breccie, og dets Grænse mod det underliggende Sand a viser sig i Profilet som en Zigzaglinje. Overgangslaget er tykkest under den nederste Del af Tellinalerbuen og er her 0,85 m mægtigt; det tynder sig ud opad paa begge Sider af Buen, mod SV. i en Højde af c. $7 \mathrm{~m}, \bmod \mathrm{N} \varnothing$. i en Højde af $9 \%_{4} \mathrm{~m} \mathrm{o.} \mathrm{H.}$

Efter at Grænsefladen har naaet sit højeste Punkt, 19 m o. H., sænker Tellinaleret sig nedad og naar Stranden c. $144 \mathrm{~m}$ ØNØ. for 0-Punktet, hvor det danner et næseformet fremspringende Skred. Grænsefladens Retning maaltes i en Højde af $9,3 \mathrm{~m}$ o. H.; den strøg N. $38^{\circ} \mathrm{V}$. og hældede c. $40^{\circ} \bmod N .52^{\circ} \varnothing$. Tellinalerets egen Lagstilling strøg N. $48-60^{\circ} \mathrm{V}$. og hældede c. $48^{\circ} \bmod \mathrm{N} .42-30^{\circ} \varnothing$.; c. ${ }^{1 / 2} \mathrm{~m}$ højere oppe strøg Grænsefladen N. $41^{\circ} \mathrm{V}$. og hældede $44^{\circ} \bmod$ N. $49^{\circ} \varnothing$.

Parti VI er $120 \mathrm{~m}$ langt. Klinten danner her 2 Fald og 2 Næser (Fremspring), ved vore Undersøgelser benævnte Nr. 13 og Nr. 17. Det sydvestlige Fald begrænses mod Sydvest af den ovenfor omtalte Næse Nr. 11 ved Nordøstenden af Parti V. Den vestlige, Nr. 13, af Parti VI's to Næser er det fremtrædende Punkt, hvor Kysten forandrer Retning fra SV.-NØ. til V.-Ø.; den østlige, Nr. 17, danner Partiets Østgrænse. Klintens Højde aftager i dette Parti til $33 \mathrm{~m}$.

Hvert af Faldene, saa vel som Faldet i det følgende Parti, omsluttes af to Vægge, der mødes under mere eller mindre stumpe Vinkler. Af disse Vægge er de, der vender mod Nordøst, tilskredne, medens de, 
der vender mod Nordvest, staar rene i større eller mindre Udstrækning i deres øverste Del. Man kan her iagttage de forskellige Aflejringers Paalejring paa hinanden og se, at de alle hælder i omtrent nordøstlig Retning.

Faldene er fremkomne ved Skred, der foraarsages af Grundvandet, som siver ud over vandstandsende Lerlag. I det vestlige Fald er Tellinaleret skredet et Stykke ud i Havet. Havets Erosion har vel fjernet meget af det udskredne Tellinaler, dog ses i Havstokken Rester af det, som ved Udskridningen har dannet smukke Folder.

Betragter vi nu Væggen, der vender mod Nordvest i de t ve s t 1 ig e F a l d mellem Nr. 11 og Nr. 13 (Fig. 15, S. 59), ser vi forneden den øverste Del af Tellinaleret, hvis nedre Del samt det underliggende Sand a er skjult af udskredne Jordmasser. Dette Tellinaler danner Fortsættelsen mod Øst af det Tellinaler, som nys er beskrevet i Parti V, i hvis sydvestlige Ende det gaar op til Overfladen.

Umiddelbart over Tellinaleret, men adskilt fra dette ved en Overskydningsflade, ses Stenlaget b, der er en Fortsættelse af Stenlaget i Parti V, i hvilket det gaar op til Overfladen. Paa et enkelt Sted i Parti VI spalter Stenlaget sig i to. Under det øverste og mægtigste, som indeholder de største Sten, findes Ler- og Sandsmører, stedvis sammenæltede til en Pseudomoræne; det nederste Stenlag hviler direkte paa Tellinaleret. Mange af Stenene i Stenlaget naar en ret betydelig Størrelse, den anseligste maalte indtil $0,7 \mathrm{~m}$; de er i største Delen af Laget kittede sammen til et brunt Konglomerat ved en Jernudskillelse. Mægtige Konglomeratblokke, nogle over $2 \mathrm{~m}$ lange, ligger nedstyrtede paa Stranden der, hvor Laget omtrent naar ned til denne (ses paa Fig. 14, S. 59). I Stenlaget er fundet en Rhombeporfyr.

Over Stenlaget er Væggen tildels tilskreden, da den her bestaar af Sand med Lerlag af større eller mindre Udstrækning, hørende til Moræne B. Hvor Væggen atter staar ren ovenover det tilskredne, ses den øvre Del af denne Moræne som en Bænk af graabrunt, magert, sandet Moræneler, der atter dækkes af Moræne C. Denne har her en Mægtighed af $5 \mathrm{~m}$ og bestaar af graablaat Moræneler. Grænsen mellem de to Moræner, der ikke er skarp, markeres væentlig ved Farveforskellen. Ved Stentællinger kan de to Moræner let holdes ude fra hinanden. De øverste $2 \mathrm{~m}$ af Klinten er sandet, meget forvitret Moræneler. Hvorvidt disse er en selvstændig Moræne, vides ikke; rimeligvis er det den diskordante Moræne D.

Gaar vi over i det østlig e Fald mellem Nr. 13 og Nr. 17, ser vi Morænerne $\mathrm{B}$ og $\mathrm{C}$ fortsætte sig i en lille Væg, der midt i Faldet rager op over de udskredne Jordmasser, idet den vender mod Nord. I den Væg, som vender mod Nordvest (Fig. 16, S. 63), ses forneden 


\section{Forklaring til Fig. 14 og 15.}

Fig. 14. Den nordøstligste Del af Parti V og den vestlige Del af Parti VI. Man ser de 3 Næser, Nr. 11 længst til Højre (den danner Nordøstgrænsen for Parti V, Nr. 13 midt i Billedet (hvor Kysten forandrer Retning fra SV-NØ til V- Ø) og Nr. 17 i Baggrunden (den danner Østgrænsen for Parti VI). Klinten dannes væsentlig af mere eller mindre udskredet Tellinaler, under hvilket der kommer frem ved Kysten midt i Billedet lidt af Sandet a. Over Tellinaleret ses Stenlaget $b$ og over dette lidt Sand b samt Moræne B i Næse Nr. 11. I Næse Nr. 13 ses foroven Moræne B og under denne Sandet b. Lidt længere nede kommer det rustfarvede Stenlag b til Syne og under dette Tellinaler, foran hvilket der ligger nedskredet Moræneler N. Paa Kysten ved den laveste Del af Næse Nr. 13 ses nogle nedstyrtede Blokke af det sammenkittede, rustfarvede Stenlag.

Fig. 15. Parti VI med Næserne Nr. 17 til Venstre og 13 til Højre, hvor Kysten forandrer sin Retning. I Faldet Sydvest for 13 ses Tellinaler, mere eller mindre udskredet; det indtager det meste af Billedets nedre Dele. Over Tellinaleret, men adskilt fra det ved en Dislokation, fremtræder Stenlaget b og over dette Sandet b, overlejret af Moræne B, som atter overlejres af Moræne C, over hvilken der øverst i Billedet ses Moræne D. I 17 ses ligeledes øverst Moræne D og under denne Morænerne C og B og Tellinaler. 1913.

\section{Explications des figures 14 et 15 .}

Fig. 14. La section la plus au nord-est de partie V, et la section ouest de partie VI. On voit les 3 saillies en forme de nez. No. 11, le plus loin à droite, (cela forme la limite nord-est pour partie V). No. 13, au centre de l'illustration, (où la côte change sa direction du S-O.-N-E. pour l'O-E), et no. 17, dans le fond, (qui forme la limite orientale pour partie VI). La falaise est principalement formée de plus ou moins grands éboulis d'argile à Tellina, sous lesquelles apparait, à la côte, au centre de l'illustration, un peu de sable a. Sur l'argile à Tellina, se trouve la couche de pierres b, et sur celle-ci un peu de sable b, ainsi que la moraine $B$, dans la saillie en forme de nez no. 11. Dans la saillie en forme de nez no. 13 on voit, en haut, la moraine B, et sous celle-ci, le sable b. Un peu plus bas, apparait la couche de pierres b, couleur de rouille, et sous celle-ci, l'argile à Tellina, devant laquelle se trouve l'éboulis d'argile morainique N. Sur la côte, à la partie la plus basse de la saillie en forme de nez no. 13, on voit un éboulis de quelques gros blocs, venant de la couche de pierres cimentée, couleur de rouille.

Fig. 15. Partie VI, avec les saillies en forme de nez no. 17 à gauche et 13 à droite, où la côte change de direction. Dans la descente au sud-ouest de no. 13, se trouve de l'argile à Tellina, plus ou moins éboulée; elle prend la plus grande partie inférieure de l'illustration. Par dessus l'argile à Tellina, mais séparée d'elle par une dislocation, apparait la couche de pierres $\mathrm{b}$, et par dessus elle, le sable b, superposé de moraine B, qui est elle-même superposée de moraine C, sur laquelle on voit, tout en haut de l'illustration, la moraine D. Dans no. 17, on voit de même, au-dessus, la moraine D, et sous celle-ci, les moraines B et $\mathrm{C}$ et l'argile à Tellina. 1913. 


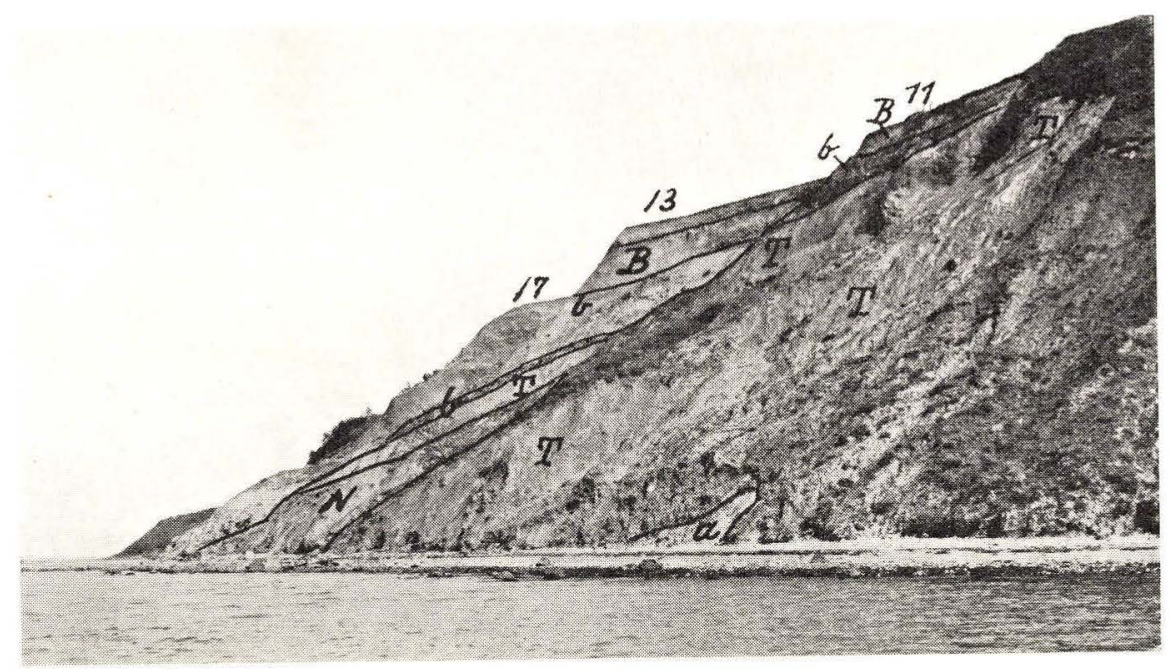

Fig. 14.

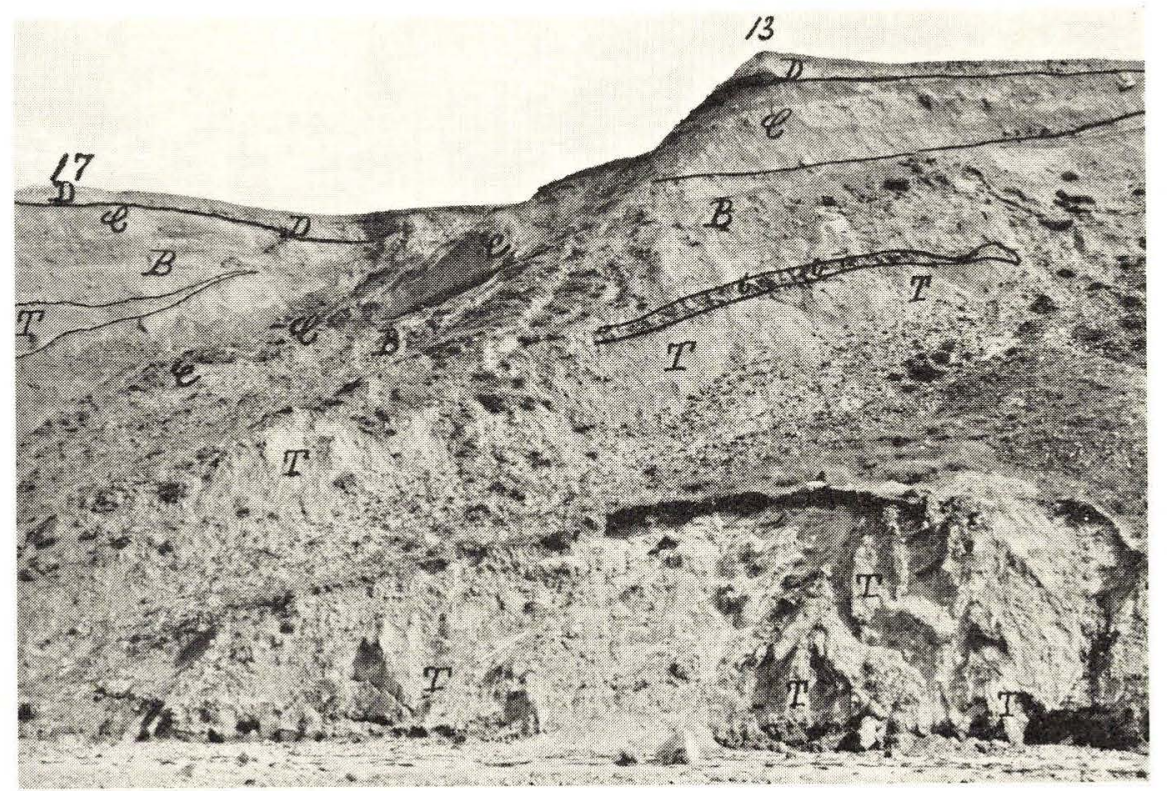

Fig. 15 . 
atter Moræne C, der har er af lys, graablaa Farve og ialt Fald stedvis meget fed og paa korte Strækninger næsten stenfri.

Over Moræne C ses mod Nordøst Tellinaler, som opad, midt i Væggen, kiler sig ud, saaledes at de over dette liggende Aflejringer kommer til at hvile direkte paa Moræne C. Tellinaleret er dog ikke normalt paalejret Moræne C; det er skubbet op over denne, saa at Grænsefladen er en Overskydningsflade. $18 \mathrm{~m}$ over Havet maaltes, at den strøg N. $57^{\circ}$ V. og hældede $40^{\circ} \bmod \mathrm{N} .33^{\circ} \varnothing . ; 1,7 \mathrm{~m}$ højere og 2,5 m længere inde paa Væggen var Strygningen N. $70^{\circ} \mathrm{V} .0 g$ Hældningen $30^{\circ} \bmod \mathrm{N} .20^{\circ} \varnothing$.; $2 \mathrm{~m}$ højere og $3,7 \mathrm{~m}$ længere inde paa Væggen end denne sidste Maaling var Strygningen N. $40^{\circ} \mathrm{V}$. og Hældningen $25^{\circ} \bmod \mathrm{N} .50^{\circ} \varnothing$.; tæt ved det Sted, hvor Tellinaleret kiler sig ud, var Strygningen N. $54^{\circ} \mathrm{V}$. og Hældningen $35^{\circ} \bmod$ N. $36{ }^{\circ} \varnothing$. Man ser saaledes, at Overskydningsfladen er en skæv og krum Flade, hvis Hældning er forholdsvis stor tæet ved, hvor Flagen kiler sig ud; derefter aftager den hurtigt for saa atter at tiltage nedad mod Nordøst ligesom den tilsvarende Overskydningsflade i Parti III.

Tellinaleret er sort, temmelig magert og indeholder, navnlig nedad til, talrige, tynde Sandlag, der ved Grænsefladen er bøjede, saa at de slæber paa denne (Fig. 17, S. 63). I sin øverste Del er Tellinaleret temmelig fedt og frit for Sand; ved Forvitring er det blevet lyst chokoladefarvet. Hvor Tellinaleret foroven mod Sydvest kiler sig ud, er det trukket ud opad, saa at det i Profil ser ud, som om det har en lille Hale. Dette, tilligemed andre Forhold, der straks skal omtales, viser, at Tellinalerets Overflade ogsaa er en Overskydningsflade og at de overliggende Aflejringer er blevne skudte frem over Tellinaleret og Moræne C.

Over Tellinaleret ses paa kortere Strækninger Grus med store Sten, der maa anses for at være Rester af Stenlaget b, saa meget mere som der (ligesom i Parti III) imellem dette Grus og Tellinaleret findes lidt Sand med tynde Lerlag; direkte under Gruset ses ogsaa her et Lerlag. Grænsefladen (Overskydningsfladen) mellem Tellinaleret og det overliggende Grus strøg N. $80^{\circ} \mathrm{V}$. og hældede $30^{\circ} \bmod$ N. $10^{\circ} \varnothing$. Lignende Grusrester ses umiddelbart paa Moræne C, hvor Tellinaleret er sluppet op.

Paa Tellinaleret og Grusresterne hviler Moræne B, der her hovedsagelig fremtræder som rødt Moræneler, indeholdende Partier af blaat Moræneler og større og mindre, linseformige Partier eller korte Lag af Grus og fint Sand. Moræne B tilligemed Resterne af Stenlaget har en Mægtighed af $6^{1} / 2 \mathrm{~m}$.

Ovenover Moræne B ses den diskordante Moræne D med Smører af Plastisk Ler; dens Mægtighed er c. $2 \mathrm{~m}$. 


\section{Forklaring til Fig. 16 og 17.}

Fig. 16. Faldet mellem Næserne 13 og 17 i Parti VI. Øverst til Venstre ses Moræne D, under hvilken der kommer Sand frem, som gaar op i Overfladen midt i Billedet. Under Sandet og Moræne D kommer Moræne B tilsyne. Under denne ses Sandet b, og under dette, helt til Venstre i Billedet, kiler Enden af en Flage Tellinaler sig ud ved Maalestokken. Sandet b fortsætter sig opad mod Vest til omtrent midt i Billedet. Derved kommer det til at hvile paa Moræne C. Mellem Moræne C og de overliggende Aflejringer $\mathrm{T}, \mathrm{b}$ og $\mathrm{B}$ er der en Overskydningsflade. 1913.

Fig. 17. En Del af den mod NV vendende Væg i Næse 17 i Parti VI. Tellinaler med tynde Sandlag, der viser Slæbning paa den underliggende Moræne C, som Tellinaleret er skudt op over. 1913.

\section{Explications des figures 16 et 17 .}

Fig. 16. La descente, entre les saillies en forme de nez, no. 13 et 17 dans partie VI. Tout en haut à gauche, on voit la moraine D, sous laquelle apparait du sable qui monte à la surface au milieu de l'illustration. Sous le sable et la moraine D, apparait la moraine B. Sous celle-ci on voit le sable $\mathrm{b}$, et sous celui-ci, tout à gauche de l'illustration, le bout d'un morceau cunéiforme d'argile à Tellina se terminant au jalon. Le sable b se continue plus loin vers le haut, dans la direction ouest et presque jusqu'au centre de l'illustration. Il arrive ainsi à reposer sur la moraine C. Entre la moraine $\mathrm{C}$ et les dépôts supérieurs $\mathrm{T}$, b et $\mathrm{B}$, se trouve une surface de charriage. 1913 .

Fig. 17. Une portion de la paroi orientée vers le nord-ouest, dans la saillie en forme de nez 17, dans partie VI. L'argile à Tellina, avec ses minces couches de sable, qui démontre un trainage sur la moraine $\mathrm{C}$ se trouvant en-dessous et que l’argile à Tellina a chevauchée. 1913. 


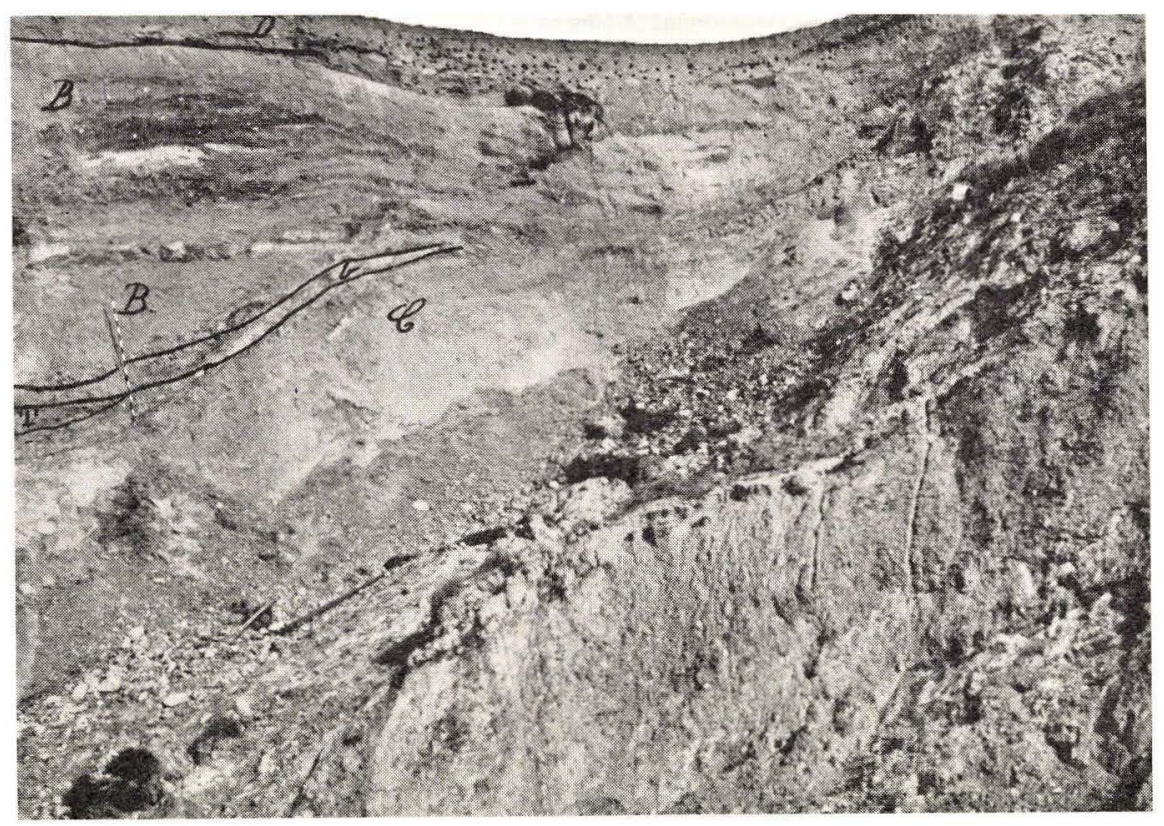

Fig. 16.

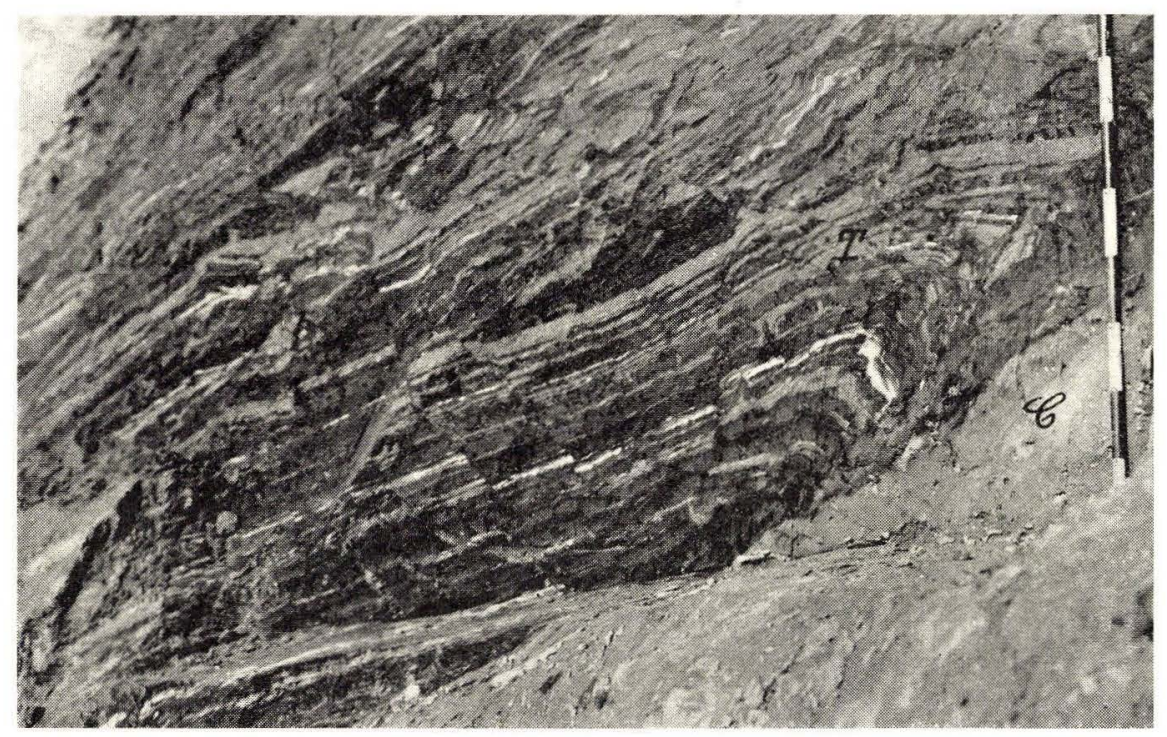

Fig. 17. 
Parti VII har en Længde af $65 \mathrm{~m}$. Klinthøjden aftager i dette Parti til $30 \mathrm{~m}$. Partiet danner et Fald, begrænset af to Næeser (Nr. 17 og Nr. 20), hvoraf Nr. 20 danner Partiets Østgrænse, medens den vestlige, Nr. 17, danner Østgrænsen for Parti VI. Faldet er i det væsentlige bygget som Faldene i dette (Fig. 18, S. 67).

Nogenlunde ren staar ikke blot den Væg, der vender mod Nordvest, men ogsaa Baggrunden af Faldet. Her ses nederst lidt af Tellinaleret, der er en Fortsættelse af Tellinaleret i det foregaaende Fald. Det er fedt, forneden blaasort, foroven chokoladefarvet. Der er ikke iagttaget Sandlag i det.

Over Tellinaleret kommer der først et tyndt Sandlag bog over dette Bænke af brunt, magert, stenfrit Ler og Sand og derover rødt Moræneler, alt hørende til Moræne B. Paa denne hviler Moræne C, som her i Baggrunden af Faldet bestaar af rødt Moræneler med underordnede Sandsmører. Nogen Grænse mellem de to Moræner er ikke nøjagtig paavist her, da Væggen er utilgængelig i største Delen af sin Udstrækning, men skønsmæssig anser vi Moræne $\mathrm{B}$ for at have en Mægtighed af c. $4 \mathrm{~m}$ og Moræne $\mathrm{C}$ af c. $3 \mathrm{~m}$.

I den mod Nordvest vendende Væg er de to Moræner lette at holde ude fra hinanden saavel paa Grund af deres Farve og Konsistens som ved Hjælp af Stentællinger. I denne Væg ses forøvigt nederst hvidt Sand (det ses ikke paa Fig. 18, da det ikke var synligt 1913, da Billedet toges), og derover Bænke af graabrunt, sandet, magert, stenrigt Moræneler med underordnede Sandlag, der saavel som det nævnte, hvide Sand tilhører Moræne B. Over denne ses Moræne C, som i den nærmest mod Havet vendende Del af Væggen bestaar af blaagraat Moræneler, men foroven hen imod Baggrunden af Faldet af rødt Moræneler.

Paa Moræene C hviler, tildels i en Fordybning i Morænen, hvidt, groft, skarpt, lagdelt Sand og fint Grus c med Skalstumper. Under dette Sand er Moræne C meget tynd, og mellem Sandet og Morænen er indlejret dels en Klump af Morænesand og dels et lille Parti fint, lagdelt Sand, hvis Lagstilling er diskordant mod det skalstumpførende Sands.

Ovenpaa det skalstumpførende Sand c findes den diskordante Moræne D, der i Baggrunden af Faldet fortsætter sig hen over Moræne C. Grænsen mellem disse to Moræner har dog ikke kunnet paavises med Sikkerhed her paa Grund af Væggens Utilgængelighed, men Moræne D's Mægtighed kan dog anslaas til c. $2 \mathrm{~m}$. Moræne D bestaar her hovedsagelig af rødt Moræneler, dog er der uforvitrede, blaa Partier i den.

Naar man nu betragter de tre Partier V, VI og VII under et, vil man se, at man to Gange i disse træffer den samme Lagserie, nemlig 


\section{Forklaring til Fig. 18 og 19.}

Fig. 18. Parti VII mellem Næserne 17 og 20. Til Højre og midt i Billedet kommer der Tellinaler frem over Skredet. Over dette ses midt i Billedet et tyndt Sandlag b og derover Moræne B og Moræne C. Over denne ses Sandet c med Molluskskalfragmenter og øverst oppe Moræne D. 1913.

Fig. 19. Parti VIII og den vestlige Del af Parti IX. Til Højre i Billedet ses den kratbevoksede Kløft, som strækker sig ind i Landet. Til Højre for denne ses Moræne D, hvilende paa Moræne C, og under denne Moræne B. I Kløften findes den Dislokation, som begrænser Horstens lodrette Grænselag mod Vest og skiller dem fra de skraatliggende Aflejringer længere mod Vest. I Næse 21 Øst for Kløften ses i lodret Stilling Moræne C, Øst for denne Moræne B og længst til Venstre Sand- og Gruslagene b med Forchhammers Lag F. Alle disse Aflejringer er dækkede af den diskordante Moræne D. 1913.

\section{Explications des figures 18 et 19.}

Fig. 18. Partie VII, entre les saillies en forme de nez 17 et 20. A droite et au centre de l'illustration, apparait l'argile à Tellina par dessus l'éboulement. On voit, par dessus celui-ci, au centre de l'illustration, une mince couche de sable b, par dessus laquelle se trouve la moraine B et la moraine C. Au dessus de cette dernière, se trouve la sable c, contenant des fragments de coquilles de mollusques, et, enfin, tout en haut, la moraine D. 1913.

Fig. 19. Partie VIII et la section ouest de partie IX. A droite, dans l'illustration, se trouve le ravin broussailleux, qui s'étend dans la campagne. A droite de celui-ci, on voit la moraine $\mathrm{D}$ reposant sur la moraine $\mathrm{C}$, et sous celle-ci, la moraine B. Dans le ravin, se trouve la dislocation qui délimite, vers l'ouest, les couches de limite verticales du horst, et les sépare des dépôts en biais, se trouvant plus loin vers l'ouest. Dans la saillie en forme de nez 21, à l'est du ravin, on voit dans une position verticale, la moraine $\mathrm{C}$, à l'est de celle-ci, la moraine $\mathrm{B}$, et le plus loin à gauche, les couches de sable et de gravier b, avec les couches F de Forchhammer. Tous ces depôts sont recouverts de la moraine D discordante. 1913. 


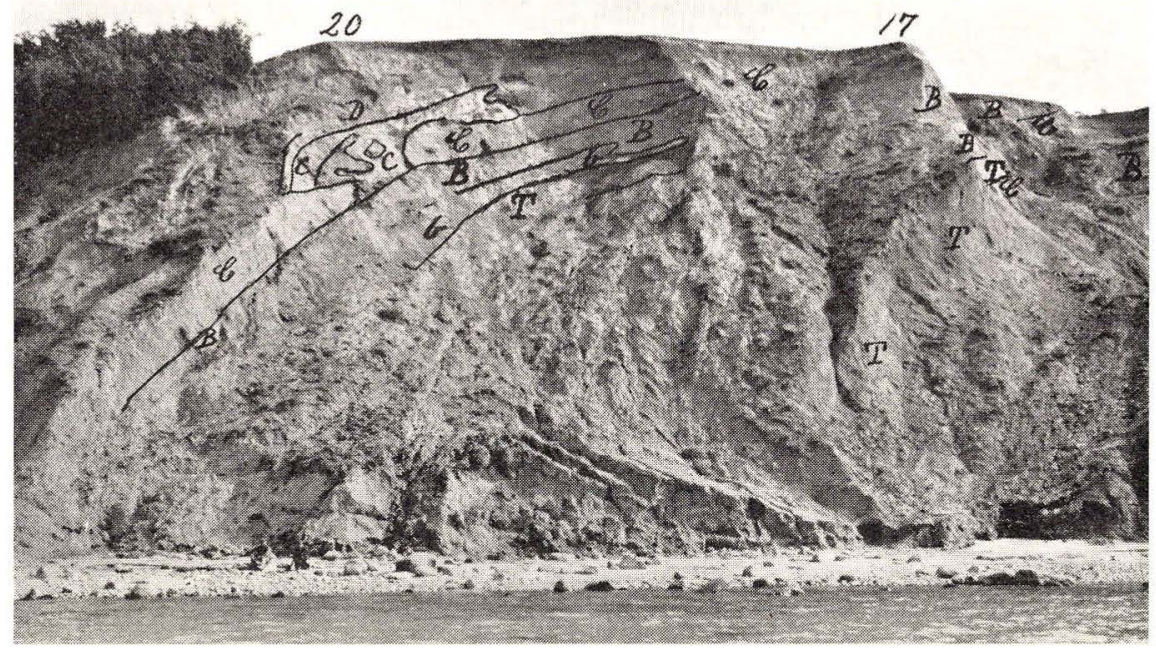

Fig. 18 .

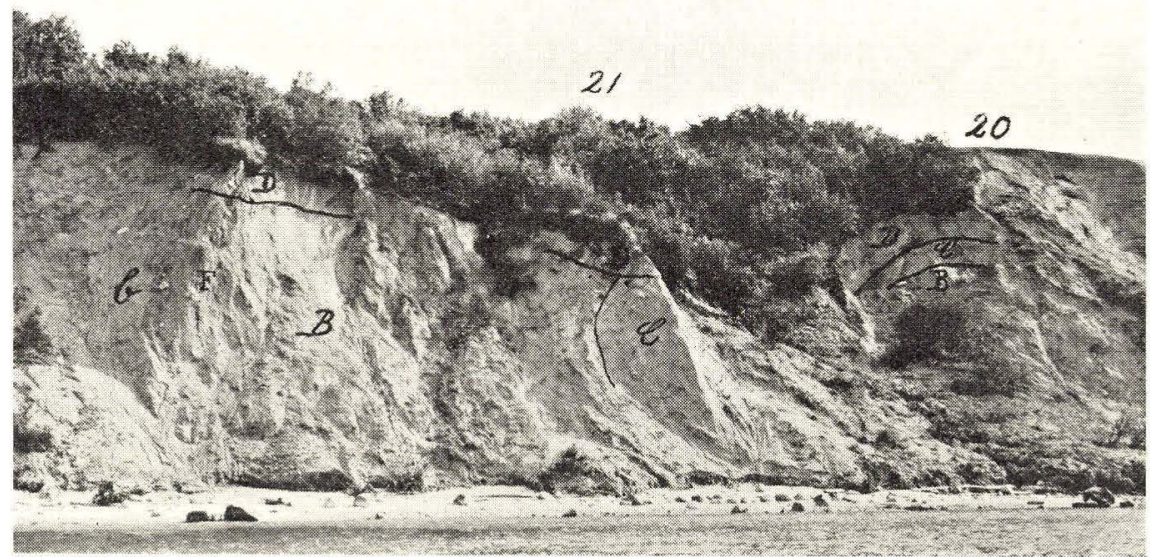

Fig. 19. 
(regnet fra neden) Tellinaler, Stenlag b, Moræne B og Moræne C. Tellinalerets Underlag, det hvide Sand a, er paavist i Partierne IV, V og VII.

De to Lagrækker er adskilte ved en Overskydningsflade, der er beliggende i Parti VI.

Paa Grund af Lagenes skraa Stilling i Klinten gaar hver Aflejring op til den diskordante Moræne paa to Steder, en Gang i hver Lagrække, med Undtagelse af Stenlaget, som i den østlige Lagrække er stærkt ødelagt.

Parti VIII er $60 \mathrm{~m}$ langt. Klinten sænker sig her til en Højde af $17 \mathrm{~m}$. Der findes her en kratbevokset Kløft, som fortsætter sig et Stykke ind i Landet, op i Gaarden Sølysts Have (Fig. 19, S. 67). Klinten er udskridende og tilskredet med Undtagelse af en lille Væg i Baggrunden mod Vest. Her ses den diskordante Moræne D med dens karakteristiske Smører af Plastisk Ler. Den hviler paa blaat Moræneler, som, efter Forholdene i Parti VII at dømme, maa være Moræne C.

Næse Nr. 21, der begrænser Faldet mod Øst, bestaar af haardt, sandet Moræneler, der paa Yderfladen i tør Tilstand ligner blaagraat Moræneler; det har dog en brunlig Tone. Paa Grundlag af de Stentællinger, der er foretaget i det, saa vel som af Grunde, der skal udvikles i det følgende, maa det anses for at være Moræne C. Denne Moræne bør dog ikke betragtes som en direkte Fortsættelse af Moræne $\mathrm{C}$ i Baggrunden og i Parti VII, da den indtager en omtrent lodret Stilling med Overfladen mod Vest. Foroven i Klinten findes den diskordante Moræne D, som her er rig paa Sandsmører.

Som det fremgaar af det følgende, maa der i dette Fald findes en anselig Dislokation, paa begge Sider af hvilken der i Klinten optræder samme Lagserie, blot med ringe Forskel i Udviklingen, men med Lagene i modsat Rækkefølge.

Parti IX er $130 \mathrm{~m}$ langt, det naar fra Næse Nr. 21 til »Glimmerlerkløften". Klinten hæver sig paa denne Strækning jævnt til en Højde af $28 \mathrm{~m}$, hvilken Højde den naar i den østligste Del af Partiet. Klintvæggen staar ret ren for oven, paa Fremspringene endog næsten ned til Klintfoden, saa at man tydelig ser, at Lagene i dette Parti omtrent staar lodret.

Som nævnt møder man her Lagene i modsat Rækkefølge af den, der findes i Partierne længere mod Vest. Lagserien danner her ligesom et Spejlbillede af Serien paa den vestlige Side af Kløften i Parti VIII. Det vil derfor være praktisk og lette Sammenligningen med de vestligere Partier at begynde Beskrivelsen af Lagene fra Øst, hvor Partiet begrænses af »Glimmerlerkløften«, hvis Bund dannes af udskridende Plastisk Ler, og hvis østlige Side helt bestaar af denne 


\section{Forklaring til Fig. $20-22$.}

Fig. 20. Den østlige Del af Parti IX med »Glimmerlerkløften $\ll$. I dennes Bund og i dens Østside findes det Plastiske Ler PL, som danner den vestlige Side af Plastisk Ler-Horsten. Dennes Grænsedislokation ligger ved Kløftens Østside. Her findes der i Skyggen Glimmerler og Glimmersand. I Klinten Vest for Kløften ses Moræne A, de glaciofluviale Lag a, en Tellinalerflage $\mathrm{T}$ højt oppe i Klinten og de glaciofluviale Lag b med Forchhamers Lag F. Over de lodretstaaende Aflejringer findes der diskordant Sand og Moræne D. 1913.

Fig. 21. Forchnamers Lag, glaciofluviale Lag b, i Parti IX. 1904.

Fig. 22. Grænsedislokationen (Spaden staar i den) mellem Plastisk LerHorsten PL og Moræne A inderst inde i »Glimmerlerkløften«. G er lidt Glimmerler. Maalestokken er inddelt i Decimeter. 1913.

\section{Explications des figures 20-22.}

Fig. 20. La section orientale de partie IX, avec »le ravin d'Argile micacée«. Dans son fond et dans sa côte orientale, se trouve l'Argile plastique PL, formant le côté le plus à l'ouest du horst de l'Argile plastique. Sa dislocation de limite se trouve à l'est du ravin. Ici, à son ombre, se trouve de l'Argile micacée et du Sable micacé. Dans la falaise, à l'ouest du ravin, se trouvent la moraine $A$, les couches glacio-fluviales a, un morceau d’argile à Tellina $\mathrm{T}$, situé très haut dans la falaise, et les couches glaciofluviales b avec les couches de Forchhammer F. Au-dessus des dépôts verticaux, se trouvent le sable et la moraine D, discordants. 1913.

Fig. 21. Les couches de Forchнammer. Couches glacio-fluviales b, dans partie IX. 1904.

Fig. 22. La dislocation de limite, (la bêche est plantée dedans), entre le horst de l'Argile plastique PL, et la moraine A, profondément à l'intérieur du »ravin d'Argile micacée«. G, désigne un peu d'Argile micacée. Le jalon est divisé en décimètres. 1913. 


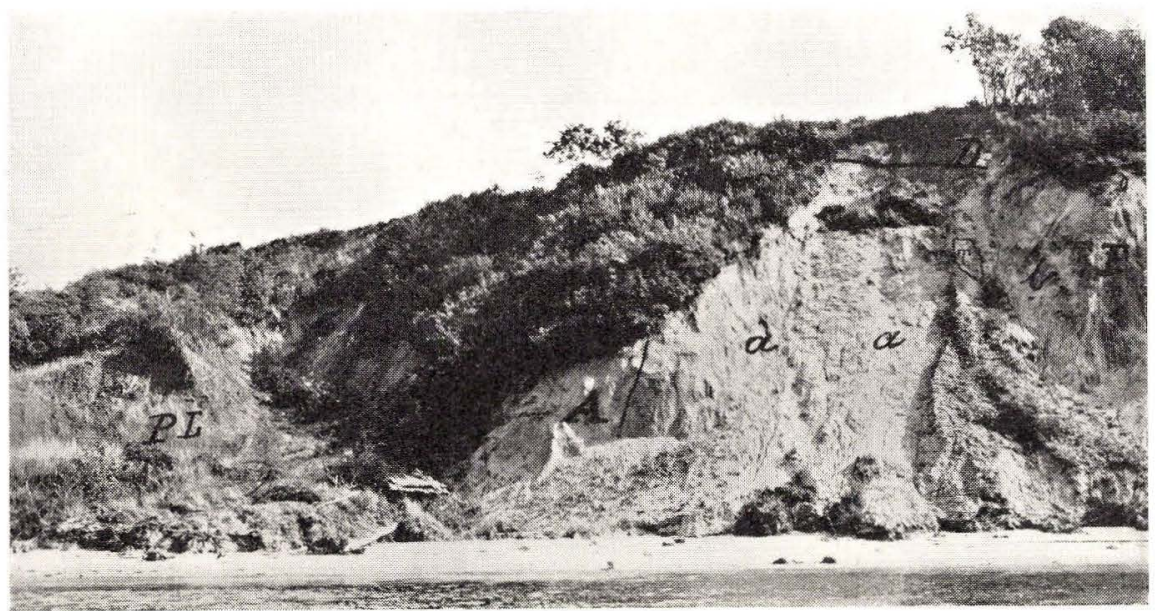

Fig. 20.

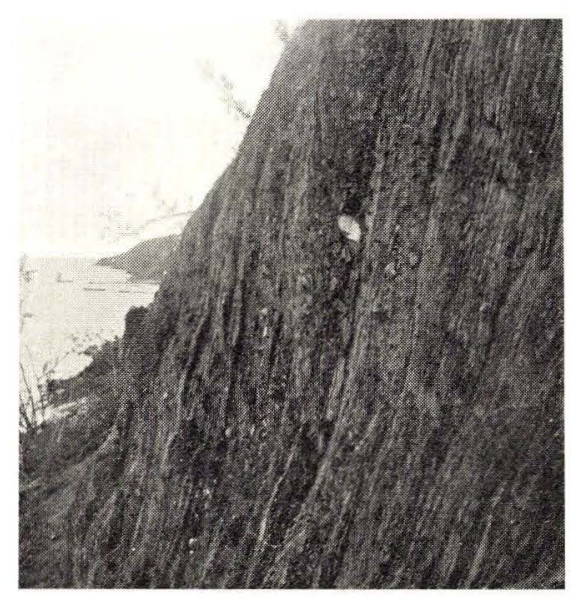

Fig. 21.

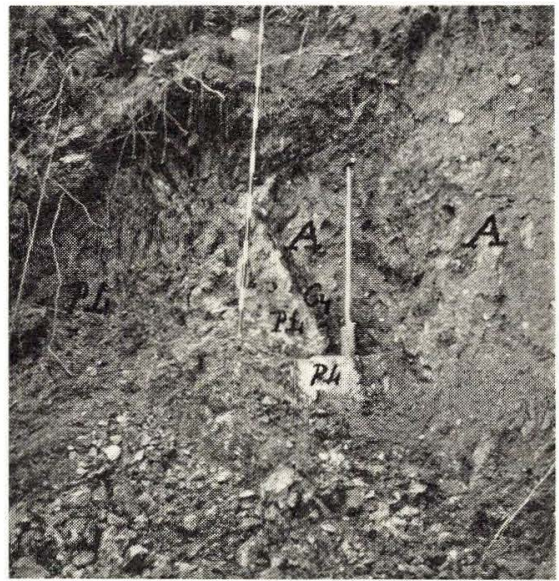

Fig. 22 
Lerart (Fig. 20, S. 71). Øst herfor findes der ved Kysten paa en Strækning af over $1 / 2 \mathrm{~km}$ udelukkende Plastisk Ler, der er udskridende i større eller mindre Grad.

I Kløftens Baggrund ses mod Øst Plastisk Ler og mod Vest Moræne A. Det Plastiske Ler er foroven brunt; graver man ned i det, ser man, at Farven dybere nede bliver blaalig. Moræne A optræder her som temmelig sandet, meleret mørkt Moræneler, der er rigt paa Sten og indeholder enkelte Sandklumper; dybere nede bliver det mere stift og blaasort af Farve. Grænsen mellem det Plastiske Ler og Moræneleret er en Dislokation (Fig. 22, S. 71), hvilket fremgaar af, at der paa Moræneleret er blevet hængende lidt (indtil $4 \mathrm{~cm}$ ) Glimmerler, paa hvilket der ved Dislokationsbevægelsen er blevet dannet en blankpoleret Glideflade, saa at det har faaet et smukt "Harnisk".

Inderst inde i Kløftens Vestside kunde vi 1913 iagttage, at Dislokationsfladen strøg N. $30^{\circ} \mathrm{V}$. og hældene $70^{\circ} \bmod \mathrm{S} .60^{\circ} \mathrm{V}$. Ved Revisionsarbejderne 1915 viste det sig, at der var foregaaet Udskridninger, saa at Stedet, hvor disse Maalinger foretoges, ikke kunde genfindes; derimod var det nu blevet muligt at foretage en Maaling af Dislokationsfladen noget dybere nede og vistnok en Smule længere ude i Kløften. Strygningen var her N. $50^{\circ} \mathrm{V}$. og Hældningen $45^{\circ}$ $\bmod N .40^{\circ} \varnothing$.

Lidt længere udad mod Kløftens Munding skjules Moræne A, som inderst inde danner Kløftens Vestvæg, efterhaanden dels af stejltstillede, tynde, vekslende Lag af sortebrunt og af lyst, mere eller mindre grønligt Glimmersand, der stryger N. $50-60^{\circ} \mathrm{V}$, dels af sort, sandet Glimmerler og dels af et glaukonitholdigt, brunt Knoldelag med Gibskrystaller og smaa sorte Korn, som de, der er beskrevne af HARDER ${ }^{37}$ ). Længere ude mod Kløftens Munding findes der i Knoldelaget daarligt bevarede, knuste Skaller og Skalfragmenter af marine Mollusker. Alle disse Lag er stærkt forstyrrede, rejste paa Kant, udtværede og gennemsatte af Spring; de indeholder inderst imod Moræne A Klumper af denne. Den virkelige Lagfølge er: nederst (॰: yderst paa Væggen) Knoldelaget, saa Glimmerleret og øverst (॰: inderst) Glimmersandet. Hvad der er tilbage af disse Lag, varierer i Tykkelse fra 0 til nogle faa Meter.

For at undersøge Grænsen mellem Moræne A og Tertiæret i Kløftens ydre Del foretog vi i 1915 i Kløftens Vestside en Gravning 2 m lang, $2 \mathrm{~m}$ dyb og 0,6 m bred. Ved denne traf vi paa et omtrent vandret Spring, med en Forskydning af det »Hængende« i vestlig Retning i Forhold til det »Liggende" paa $25 \mathrm{~cm}$. Over Springet fandtes længst mod Vest Moræne A, hvis østlige Grænseflade hældede $65^{\circ} \bmod \mathrm{S}$. $65^{\circ} \mathrm{V}$. og strøg N. $25^{\circ} \mathrm{V}$. Moræneleret stødte ved denne op til en Masse af hvidt Sand, der nedad blev bredere, til den nederst naaede 
en Bredde af $70 \mathrm{~cm}$. Mellem det hvide Sand og Springet fandtes der Grus, som tog til i Tykkelse mod Vest fra $0-16 \mathrm{~cm}$; enkelte af Stenene deri naaede en Størrelse som en knyttet Haand; der fandtes saavel krystallinske Stenarter som Flint. Paa Østsiden af det hvide Sand var der en Belægning af nogle faa Centimeter udtværet, sort Glimmerler, der atter grænsede til gulbrunt Plastisk Ler. Grænsefladen mellem dette og Glimmerleret var en krum Dislokationsflade, der strøg N. $20^{\circ} \mathrm{V}$. og hvis Hældning tog jævnt til nedad fra $50^{\circ}$ til $70^{\circ} \bmod \mathrm{N}$. $70^{\circ} \varnothing$. Under det omtalte Spring fandtes ogsaa længst mod Vest Moræneleret, hvis østlige Grænseflade her hældede $65^{\circ} \bmod$ N. $65^{\circ} \varnothing$.

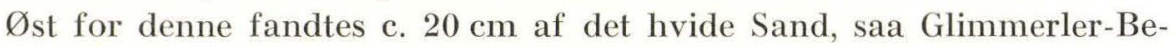
lægningen og derpaa det Plastiske Ler. Dislokationsfladen mellem Glimmerleret og det Plastiske Ler strøg her N. $25^{\circ} \mathrm{V}$. og hældede $50^{\circ}$ $\bmod$ N. $65^{\circ} \varnothing$.

Ved denne Gravning lykkedes det os saaledes at træffe Fortsættelsen af Dislokationen mellem det Plastiske Ler og Moræne A, der var fundet inderst inde i Kløften. De foretagne Maalinger af

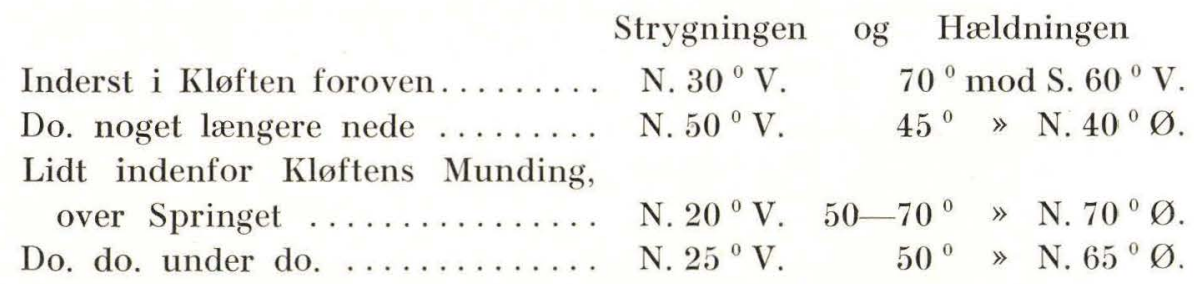

viser, at medens Dislokationsfladens Strygning kun skifter Retning i temmelig ringe Grad $\left(30^{\circ}\right)$, varierer Hældningen ikke alene i Størrelse (fra $45^{\circ}$ til $70^{\circ}$ ), men endogsaa i Retning (fra S. $60^{\circ} \mathrm{V}$. til N. $70^{\circ} \varnothing$.). Dislokationsfladen er saaledes en skæv og krum Flade.

Paa Vestsiden af Kløftens Munding kunde man 1912 forneden i Klinten mod Kysten iagttage Glimmerleret, som var skilt fra Moræne A ved et tyndt Lag af Glimmersand, der var rejst paa Kant og som strøg N. $35^{\circ} \mathrm{V}$. Nu ser man kun her M oræne A, der er $5-6 \mathrm{~m}$ mægtig og bestaar af sortebrunt Moræneler med talrige Sandsmører, som viser sig omtrent lodrette, da Morænen er rejst paa Kant. Morænens øverste Del indeholder store Sandklumper.

Mellem Moræne A og de glaciofluviale Lag a findes der en Zone, $70 \mathrm{~cm}$ mægtig, som overvejende bestaar af Sandlag, hvori der flere Steder ses tydelig fluvial Struktur, og hvori der sidder spredte Sten, men mellem disse Sandlag findes der tynde Striber af Moræneler, indtil $10 \mathrm{~cm}$ tykke. I Sandlagene findes der underordnede tynde Lerlag. I denne Zone foretoges følgende Maalinger: 
En Morænelerstribe tæet

ved Moræne A ..... strøg N. $34^{\circ} \mathrm{V}$. og hældede $85^{\circ} \bmod$ N. $56^{\circ} \varnothing$.

Et Sandlag med sorte

Klumper længere m.V. strøg N. $31^{\circ} \mathrm{V}$. og hældede $84{ }^{\circ} \bmod$ N. $59^{\circ} \varnothing$.

Et tyndt Lerlag med

stærkt udtværede sorte

Klumper, længere m.V. strøg N. $28{ }^{\circ} \mathrm{V}$. og hældede $86{ }^{\circ} \operatorname{mod~S.~} 62^{\circ} \mathrm{V}$. Do. do. . . . . . . strøg N. $26^{\circ} \mathrm{V}$. og hældede $85^{\circ} \operatorname{mod~S.~} 64^{0} \mathrm{~V}$. Do. do. . . . . . strøg N. $30^{\circ} \mathrm{V}$. Hældningen kunde ikke bestemmes.

I Zonen iagttoges et mod Vest svagt hældende Spring, hvis »Hængende« var forskudt knap en halv Meter mod Vest i Forhold til det "Liggende«.

Gaar man nu videre langs Kysten mod Vest, ser man d e g l a c i ofluviale Lag a træde frem i Klinten paa en Strækning af omtrent $20 \mathrm{~m}$. Man møder først lodrette, gule eller brunlige Sandlag; i nogle af disse ses talrige sorte, noget afrundede Stumper, der kan ligge i hele Rækker. Nogle af disse Stumper bestaar af Brunkul-Gytje, andre af Glimmerler. Desuden forekommer der i Sandlagene »Rullesten« af Moræneler og enkelte Sten. Mellem Sandlagene findes fine Lerlag. Lagrækken viser lodretstaaende Krydslejring og er gennemsat af smaa, vandrette Spring. Strygningen maaltes til N. $20-45^{\circ} \mathrm{V}$. Vest for disse Lag kommer der hvide, glimmerholdige Sandlag, vekslende med mere eller mindre talrige, snart tyndere og snart tykkere Lag af graat stenfrit Ler, men Sandlagene er de overvejende. Ogsaa i disse Lag findes der, omend sparsomt, Klumper af Brunkul og Glimmerler og enkelte Sten. Disse Lag hører ogsaa til de glaciofluviale Lag a.

Vest for disse Lag ser man, hvor Klinten staar ren, d e g l a c i ofluviale Lag b: først vekslende Lag af Sand og Ler, saa et Lag af Grus med Barnehoved-store og endnu større Sten, derpaa atter vekslende Sand- og Lerlag samt enkelte Gruslag. Disse Lag indeholder ogsaa sorte Stumper, og nogle af Lagene er helt fulde af dem. I en af disse sorte Klumper fandtes tertiære Forsteninger, bl. a. et Aftryk af en Leda. Nogle af Sand- og Lerlagene indeholder spredte Sten. Derefter kommer der Lag af daarligt sorteret Grus; de ældste (østligste) af disse indeholder endnu de sorte Stumper. I et af Gruslagene fandtes Hoved-store og endnu større Sten, indtil en halv Meter i Tvermaal. Den samlede Mrgtighed af de glaciofluviale Lag b er c. $11 \mathrm{~m}$. Tynde Lerlag c. $0,5 \mathrm{~m}$ fra Lagrækkens Østgrænse strøg N. $40^{\circ}$ V., Lag med sorte Stumper c. $1 \mathrm{~m}$ fra Lagrækkens Østgrænse strøg N. $48-50^{\circ} \mathrm{V}$, andre $\operatorname{Lag} \mathrm{N} .34^{\circ} \mathrm{V} . \operatorname{og} \mathrm{N} .37^{\circ} \mathrm{V}$. Alle de maalte Lag stod saa godt 
som lodrette. Det er disse Lag, der saa hyppig omtales og afbildes af Forchhammer; Geologerne kalder dem derfor for Forchhammers Lag (Fig. 21, S. 71).

Forchnammers Lag er, hvilket allerede Forchnammer har bemærket, foroven i Klinten skarpt afskaarne af Moræneler. Det er den diskordante Moræne D, der er $1 \mathrm{~m}$ tyk og som her hovedsagelig er dannet af Plastisk Ler.

Ved ikke ubetydelige Gravninger 1915 i Klintens øvre Del, hvor denne Øst for Forсннаммевs Lag er dækket af nedskredne Jordmasser, lykkedes det os at paavise, at der mellem de glaciofluviale Lag a og b ogsaa her findes en Flage af Tellinaler. Denne har Form som en skraatliggende, tresidet Pyramide, der vender Spidsen lidt udad og nedad, og som har ujævne, krumme Sideflader. Dens ene Sideflade ligger i Klintens Yderflade, den betegner vi som Nordsiden, de to andre Sideflader ligger inde i Skrænten, dem betegner vi henholdsvis som Østsiden (Tellinaflagens Underside) og Vestsiden (Tellinaflagens Overside). Østsiden er Grænsefladen mod de glaciofluviale Lag a. Vestsiden er Grænsefladen mod de glaciofluviale Lag b. Begge disse Grænseflader er Dislokationsflader, hvilket fremgaar af det følgende. Ved Gravningen blottede vi Nordsiden i en Højde af $5 \mathbf{m}$; foroven var dens Bredde 2,5 m, forneden 1,5 m. Her gennemskar vi desuden Pyramiden med en Flade, lagt vinkelret paa Strygningen af Pyramidens Østside, hvorved der fremkom en Trekant, der vendte en Spids nedad og en Side opad; denne var 1,5 m lang, Østsiden 1,2 m og Vestsiden $1,7 \mathrm{~m}$. Ved Nivellement med Haandniveau bestemtes, at Trekantens nedadvendende Spids laa $14,7 \mathrm{~m}$ over Havfladen. Tellinalerflagens Østside (Undersiden) strøg N. $38^{\circ} \mathrm{V}$. og hældede $65^{\circ} \bmod$ S. $52^{\circ}$ V., medens Vestsiden (Oversiden) strøg N. $43^{\circ} \mathrm{V}$. og hældede $70^{\circ} \bmod \mathrm{N} .47^{\circ} \varnothing .2,4 \mathrm{~m}$ højere strøg Østsiden N. $33^{\circ} \mathrm{V}$. og hældede $86^{\circ} \bmod \mathrm{S} .57^{\circ} \mathrm{V}$., medens Vestsiden strøg N. $42^{\circ} \mathrm{V}$. og hældede $40^{\circ} \bmod N .48^{\circ} \varnothing$. I samme Højde maaltes, at et af Tellinalerflagens Lag, der var rigt paa Glimmer, og som laa omtrent midt i Flagen, strøg N. $30^{\circ} \mathrm{V}$. og hældede $86^{\circ} \bmod \mathrm{S} .60^{\circ} \mathrm{V}$. Østsiden er altsaa omtrent parallel med Lagene i Flagen.

Paa Grænsen mellem Tellinalerflagen og de glaciofluviale Lag a findes der et Rustlag. De nederste (østligste) bevarede $20 \mathrm{~cm}$ af Tellinaleret bestaar af fedt, blaasort Ler med enkelte mindre Stumper af sort tertiært Materiale. Derpaa kommer der et 3-4 cm tykt Lag, der saa godt som udelukkende er dannet af disse sorte Brokker. (Saadanne findes ogsaa undtagelsesvis i Tellinaleret andre Steder, f. Eks. i Parti V). Saa kommer der $13 \mathrm{~cm}$ fedt Ler, dernæst $10 \mathrm{~cm}$ magert sandet Ler, der afsluttes med et $2 \mathrm{~cm}$ tykt Lag af gult, groft, skarpt Sand med enkelte sorte Brokker. Over dette veksler Bænke af fedt 
Ler med tyndere Lag af magert Ler, Sand og sorte Brokker. Paa Grænsen mellem Tellinalerflagen og de glacio-fluviale Lag b findes ogsaa et Rustlag. Inde i Tellinalerflagen findes der ligeledes Rust og andre mineralske Udskillelser.

De glaciofluviale Lag b støder mod Tellinalerlagens Vestside under spidse Vinkler, der paa Grund af Grænsefladens Zik-Zak-Form vender Spidserne snart opad og snart nedad, dog mest nedad. Der findes saaledes en Dislokation mellem Tellinaleret og de glaciofluviale Lag b. Kanten mellem Tellinalerflagens Østside og Vestside er trukket ud nedad. Den kunde med en Strygning af N. $54^{0}$ V. følges c. $4 \mathrm{~m} \mathrm{mod}$ Sydvest paa en vandret Afsats, der blev gravet vinkelret paa Strygningen af de glaciofluviale Lag b. Saa delte den sig i tre Striber, der gik videre med ringe Mellemrum. Den midterste af disse kommer til Syne paa den stejle Klint-Væg, der ses fra Kysten, som en Dislokation. Vi anser derfor denne Dislokation, der $9 \mathrm{~m}$ over Havfladen stryger N. $35^{\circ} \mathrm{V}$., og hælder $72^{\circ} \bmod \mathrm{N} .55^{\circ} \varnothing$., for at være en Fortsættelse af Dislokationen mellem Tellinaleret og de glaciofluviale Lag b og opfatter den som Grænsefladen mellem de glaciofluviale Lag a og de glaciofluviale Lag b i Klint-Væggen, hvor Tellinaleret mangler.

De østlige af de glaciofluviale Lag a, de gule Sandlag med de sorte Brokker, staar lodret; de følgende Lag, de hvide Sandlag med de tynde Lerlag, er ved Tellinalerflagens Bevægelse paa en Strækning af nogle Meter blevet bøjede fra den lodrette Stilling, saa at de næsten horizontalt løber ind mod Tellinalerflagens Østside og slæber opad med denne nærmest ved Flagen. Sandlagene er gennemsatte af talrige Smaaspring, lodrette eller svagt hældende. Desuden er der sket Forskydninger parallelt med Lagfladerne; et Sted var der saaledes paa et af de tynde Lerlag fremkommet en smuk Glideflade, der et Sted strøg N. $82^{\circ} \varnothing .0 \mathrm{~g}$ hældede $32^{\circ} \bmod N .8^{\circ} \mathrm{V}$., et andet Sted N. $88^{\circ} \varnothing .0 \mathrm{og}$ hældede $30^{\circ} \bmod$ N. $2{ }^{\circ}$ V. I de bøjede hvide Sandlag, der var krydslejrede, maaltes Strygninger paa N. $72^{\circ}$ V., N. $55^{\circ}$ V., N. $50^{\circ}$ V.; læn-

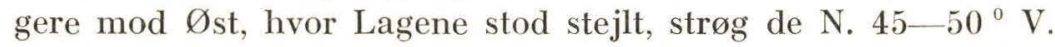

(Af V. Nordmann). For muligvis at faa yderligere detaillerede Oplysninger om dette Tellinaler-Partis Form og Udstrækning foretoges af Nordmann og Sigurd Hansen i 1931 en ny Udgravning paa samme Sted (Fig. 23 og 24, S. 79).

Efter at have opsøgt og fundet Tellinalerflagen mellem de glaciofluviale Lag a og b blottedes den paa den Maade, at Væggen paa det Areal, indenfor hvilken Flagen fandtes, afgravedes i 5 Trappetrin paa c. 1 m's Bredde og omtrent lignende Højde.

Det viste sig, at Tellinalerflagens nedadvendende Spids ligger c. 14,5 m o. H., og at Flagen kan følges op til c. 19 m over Havet. Her er den dog stærkt udtværet og smøreformet; c. $1 \mathrm{~m}$ lavere begynder den egent- 


\section{Forklaring til Fig. 23 og 24.}

Fig. 23. Udgravningen i Tellinalerflagen i Parti IX 1931. Maalestokken, som staar i Udgravningen, er inddelt i Decimeter. Øst (til Venstre) for Udgravningen ses de glaciofluviale Lag a og Vest for den de glaciofluviale Lag b med Forchnammers Lag F. Sigurd Hansen fot. 1931.

Fig. 24. Østsiden af Tellinalerflagen i Parti IX. Den venstre Tredjedel af Billedet er det hvide Sand a med dets Lerlag. Til Højre for dem ser man Tellinalerflagen T. Sigurd HAnSEN fot. 1931.

\section{Explications des figures 23 et 24.}

Fig. 23. Fouille dans le morceau de l'argile à Tellina, dans partie IX. 1931. Le jalon qui est planté dans cette fouille, est divisé en décimètres. A l'est (à gauche) de la fouille, se trouvent les couches glacio-fluviales a, et à l'ouest de la même, les couches glacio-fluviales b, avec les couches de Forchhammer F. Sigurd Hansen phot. 1931.

Fig. 24. Le côté orientale du morceau d'argile à Tellina, dans partie IX. La troisième partie, à gauche de l'illustration, est le sable blanc a, avec ses couches d'argile. A droite de celles-ci, on voit le morceau d'argile à Tellina T. Sigurd Hansen phot. 1931. 

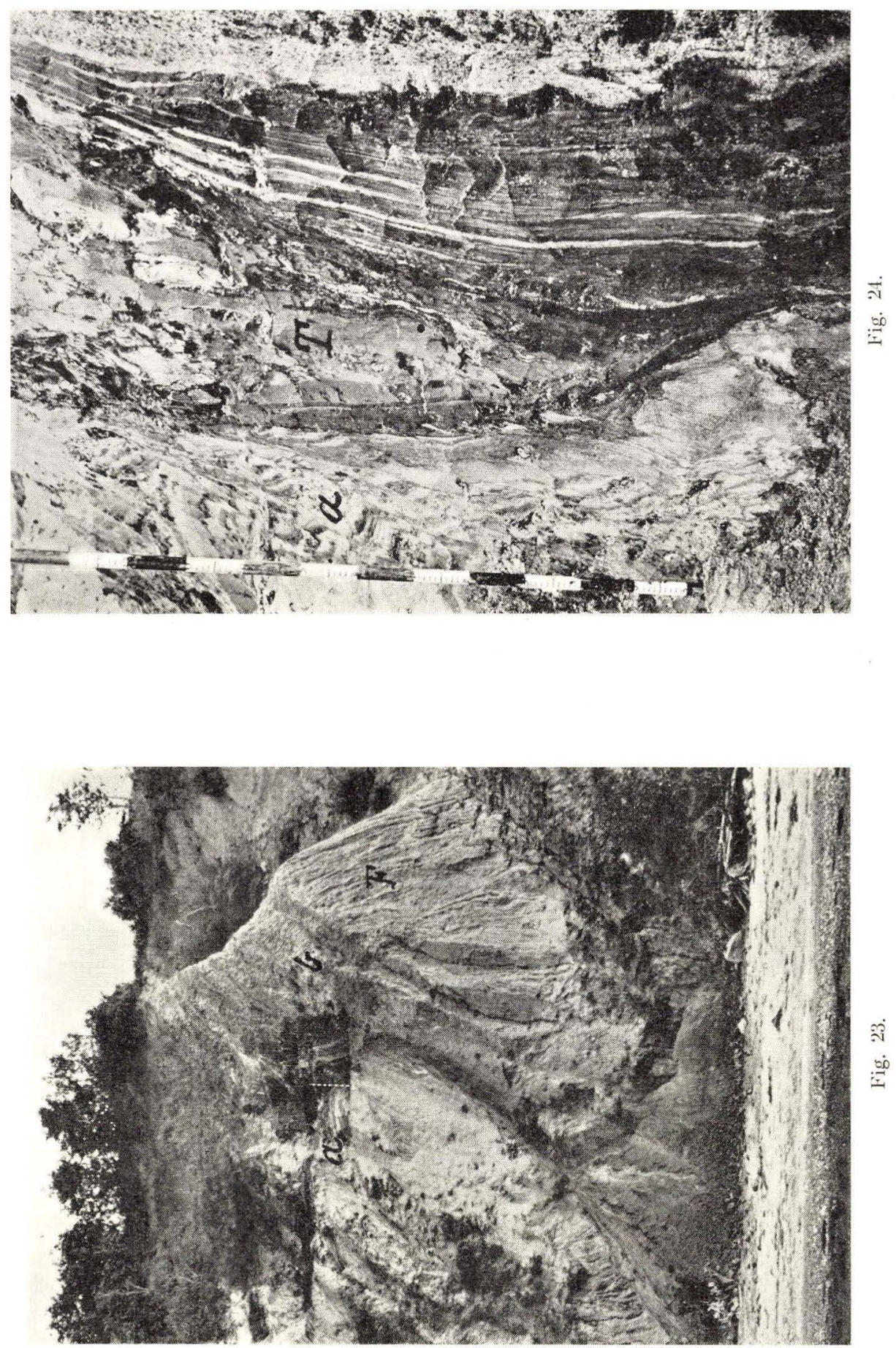
lige, kileformede Flage. Et Par Steder langs dens Sider saas Sporene efter den gamle Gravning fra 1915.

Paa næstøverste Trin, som laa c. $18 \mathrm{~m}$ o. Havet, strøg Oversiden af Flagen N. $30^{\circ} \mathrm{V}$. og Hældningen var $64^{\circ} \bmod \varnothing .30^{\circ} \mathrm{N}$., men Maalet har ikke megen Værdi, fordi Fladen er meget uregelmæssig. Undersiden af Flagen strøg noget lignende og hrldede $87^{\circ} \bmod \mathrm{V} .30^{\circ} \mathrm{S}$. Flagen var, maalt vinkelret paa dens Midtakse, som den viste sig i den vandrette Trinflade, 1,3 m mægtig.

Paa 3die Trin, som laa $0,9 \mathrm{~m}$ under det foregaaende, strøg U n d e rf 1 a d e n N. $28^{0}$ V. og hældede $74^{\circ} \bmod$ V. $28^{\circ}$ S., medens Overfladen, som stedvis var meget uregelmæssig, i det store og hele strøg N. $45^{\circ} \mathrm{V}$. og hældede $82^{\circ} \bmod$ N. $45^{\circ} \varnothing$. Flagens Tykkelse $1,3 \mathrm{~m}$.

Paa 4de Trin, som laa $0,85 \mathrm{~m}$ under det foregaaende, strøg U n d e rf l a d e n N. $38^{\circ} \mathrm{V}$. og hældede $72^{\circ} \bmod \mathrm{S} .52^{\circ} \mathrm{V}$. Overfladen strøg N. $50^{\circ} \mathrm{V}$. og hældede $60^{\circ} \bmod$ N. $40^{\circ} \varnothing$. Flagens Tykkelse $0,95 \mathrm{~m}$.

Paa 5te Trin, som laa $15,25 \mathrm{~m}$ o. H., strøg U n d e r f l a d e n N. $36^{0}$ V. og hældede $67^{\circ} \operatorname{mod~S.~} 54^{\circ} \mathrm{V}$. Overfladen strøg N. $50^{\circ} \mathrm{V}$. og hældede $70^{\circ} \bmod$ N. $40^{\circ} \varnothing$. Flagens Tykkelse $0,6 \mathrm{~m}$.

Ved Flagens Spids, som fandtes c. $14,5 \mathrm{~m}$ o. H., var Strygningen N. $37^{\circ} \mathrm{V}$. Fortsættelsen af Spidsen, altsaa Grænsen mellem Sandlagene a og $\mathrm{b}$, hældede $88-90^{\circ} \bmod \mathrm{V}$.

Paa 5te Trin maaltes Hældning og Strygning af nogle af de nærmest over (Vest for) Tellinalerflagen liggende Lag b.

Nr. 1. Et sandet Lerlag $15 \mathrm{~cm}$ over Tellinalerflagen (Tf). Strygning N. $50^{\circ} \mathrm{V}$. Hældning $80^{\circ} \bmod$ N. $40^{\circ} \varnothing$.

Nr. 2. Overkanten af et c. $6 \mathrm{~cm}$ tykt Lag af sortebrune Smaaknolde $40 \mathrm{~cm}$ over Tf. Strygning N. $52^{\circ} \mathrm{V}$. Hældning $86^{\circ} \bmod \mathrm{S} .38^{0} \mathrm{~V}$.

Nr. 3. Fint, tyndt, lyst Sandlag, $46 \mathrm{~cm}$ over Tf. Strygning N. 52 . V. Hældn. $84^{\circ} \bmod$ S. $38^{\circ} \mathrm{V}$.

Nr. 4. Underkanten af et $5 \mathrm{~cm}$ tykt Lag af grove, sorte Lerklumper $62 \mathrm{~cm}$ over Tf. Strygning N. $54^{\circ}$ V. Hældn. $74^{\circ} \operatorname{mod~S.~} 36^{0} \mathrm{~V}$.

Nr. 5. Et faa Centimeter tykt Lag af middelgroft, lyst Sand, liggende midt i den udprægede Knolderegion 1,2 m over Tf. Strygning N. $39^{\circ}$ V. Hældn. $79^{\circ} \bmod$ S. $51^{\circ} \mathrm{V}$.

Ovenover, paa 4de Trin, var Nr. 1 ikke længere sikkert iagttagelig, da det her laa for tæet paa Tf.'s Overflade. $\mathrm{Nr} .2$ laa her $17 \mathrm{~cm}$ fra Tf. Strygning N. $37^{\circ}$ V. Hældn. $89^{\circ} \bmod$ N. $53^{\circ} \varnothing$.

Nr. 3 laa $21 \mathrm{~cm}$ fra Tf. Strygning N. $42^{\circ} \mathrm{V}$. Hældn. $82^{\circ} \bmod \mathrm{N}$. $48^{\circ} \varnothing$.

Nr. 4 laa her $32 \mathrm{~cm}$ fra Tf. Strygning N. $44^{\circ} \mathrm{V}$. Hældn. $75^{\circ} \bmod$ N. $46^{\circ} \varnothing$.

Nr. 5 laa $95 \mathrm{~cm}$ fra Tf. Strygning N. $28^{\circ} \mathrm{V}$. Hældn. $78^{\circ} \bmod$ S. $62^{\circ} \mathrm{V}$. 
Endvidere maaltes Sandlag i den glaciofluviale Lagrække a (Øst for Tellinalerflagen).

1) c. $0,35 \mathrm{~m} \varnothing$. f. Tf. Strygning N. $40^{\circ} \mathrm{V}$. og Hældn. $68^{\circ} \bmod \mathrm{SV}$., men her er noget Brok i det, fordi vi her er inde i »Slæbet « mod Tellinalerflagens Underside.

2) $2 \mathrm{~m} \varnothing$. f. Tf. Strygning N. $66^{\circ}$ V. Hældn. c. $37^{\circ} \bmod$ N. $24^{\circ} \varnothing$.

3) $6 \mathrm{~m}$ Ø. f. Tf. Strygning N. $60^{\circ}$ V. Hældn. $34^{\circ} \bmod N .30^{\circ} \varnothing$, umiddelbart Vest herfor en Forkastning.

4) $8 \mathrm{~m} \varnothing$. f. Tf.'s Underside. Strygning N. $54^{\circ}$ V. Hældn. $43^{\circ} \bmod$ N. $36^{\circ} \varnothing$.

5) $9 \mathrm{~m} \varnothing$. f. Tellinalerflagens Underside paa 4de Trin strøg Sandlagene gennemsnitlig N. $58^{\circ} \mathrm{V}$. og hældede $48^{\circ} \bmod \mathrm{N} .32^{\circ} \varnothing$.

(Af Victor Madsen). Gaar man videre langs Klinten mod Vest, træffer man paa M or $\mathfrak{n}$ e B, hvis Mægtighed kan anslaas til c. $23 \mathrm{~m}$. Der er dog ret jævn Overgang mellem de glaciofluviale Lag b og Moræne $B$, idet denne Morænes nederste Del bestaar af vekslende lodrette Bænke af Moræneler og Sandlag og Sandsmører; en saadan strøg N. $23^{\circ} \mathrm{V}$. og hældede $88^{\circ} \bmod$ N. $67^{\circ}$ Ø. Den nedre (østlige) Del af Morænen udmærker sig i det hele taget ved sin lodrette Bænkning. Nogle af Morænelerbænkene er sortebrune og aabenbart væsentlig dannede af Glimmerler, andre er lysere brune og atter andre er blaasorte og mere normale. Sandsmører træffes højt op i Morænen. I den øvre Del, der er mere ensartet graabrun, findes der en $1 \mathrm{~m}$ mægtig Aflejring af Sand med tynde Leraarer og fint Grus med kvartært Præg. En af disse fine Leraarer strøg N. $35^{\circ} \mathrm{V}$. og hældede $80^{\circ} \bmod$ N. $55^{\circ} \varnothing$.

Paa denne Aflejring følger der ${ }^{1 / 2}-3 /{ }_{4} \mathrm{~m}$ graabrunt Moræneler med Sandsmører og graablaat Moræneler — stadig Moræne B, — som uden skarp Grænse gaar over i den graablaa, mindre stenrige Moræne C, der danner Afslutningen af Parti IX mod Vest.

Disse Moræner er foroven i Klinten afskaarne af den diskordante Moræne D, der bestaar af Moræneler med Smører af Plastisk Ler og Sand, samt fint Grus, der lommeformigt gaar ned i de underliggende Moræner.

\section{Oversigt.}

Af V. Nordmann.

Den Halvø, der i det nordvestlige Fyn skyder sig ud mellem Lillebelt og Baaring Vig, har Form som et fladt, hvælvet Skjold med bueformet Midtlinje, der i nord-sydlig Retning løber fra Røgle Nyhave til Vejlby, og hvis højeste Punkt $71 \mathrm{~m}(226 \mathrm{Fod})$ findes ved det trigonometriske Punkt lidt Syd for Gaarden Katrinebjerg.

Denne Halvø er mod Øst, Nord og Nordvest, fra Vejlby Skov ved Baaring Vig til Røgle Mose Øst for Strib, begrænset af bratte Klinter 
Paa store Strækninger staar disse Klinter nogenlunde rene, men paa de største Strækninger er de tilskredne og græs- eller skovbevoksede. Klinten paa Østsiden ud mod Baaring Vig, mellem Vejlby Skov og Stavrhoyed bestaar i langt overvejende Grad af kvartære Aflejringer, Moræneler og glaciofluvialt Sand, kun hist og her — snart foroven (Øst for Vejlby Skov), snart i Foden (Nord og Syd for Stutterigaarden) træder det Plastiske Ler frem. Dette kan næppe noget Sted her anses for faststaaende, men maa opfattes som løse Flager i Morænen. Fra Stavrhoved til den egentlige Røgle Klint udgøres Klinten derimod hovedsagelig af Plastisk Ler, der for saa vidt kan kaldes »faststaaende», som det efter al Sandsynlighed ikke hviler paa Kvartæret eller yngre tertiære Aflejringer, men som dog næppe helt indtager sin oprindelige Plads. I Klinten Nordvest for Holmehus ses nemlig, som omtalt S. 20, i en af de talrige Kløfter, som er fremkommet hovedsagelig paa Grund af Lerets udskridende Tilbøjelighed, en Væg, der indeholder talrige Lag af vulkansk Aske og Moler-lignende Lag; da saadanne udelukkende er kendt fra den nedre Del af det Plastiske Ler, er der al Grund til at tro, at vi her har den ældste Del af dette Ler, og at det er stedse yngre Dannelser, vi træffer, naar vi fjerner os fra dette Sted, hvad enten vi gaar mod Øst eller mod Vest. Hele Massen af det Plastiske Ler er da at betragte som en fra Dybet oppresset »Horst«.

Kun paa tre Steder i denne Klint ser man kvartære Dannelser, saavel Moræneler som glaciofluvialt Sand, nemlig ved Øst- og Vestenden af Kassemose Skov og c. $700 \mathrm{~m}$ ØNØ. for Gaarden Sølyst. Disse Steder maa nærmest opfattes som kæmpemæssige Sprækker i det Plastiske Lers Overflade, fyldt med nedgledne eller nedpressede kvartære Jord-

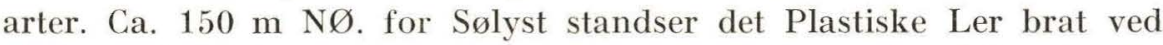
"Glimmerlerkløften", hvis Vestside dannes af Moræneler (Moræne A), delvis beklædt med Resterne af de oligocæne Sand- og Lerlag.

Fra nu af og til Klintens Ende ved Røgle Mose udgøres Klinten af de kvartære Dannelser, hvis Lejringsforhold indgaaende er skildret i det foregaaende, og af hvilke der her skal gives en kort Oversigt.

Den fuldstændige Serie af de kvartære Lag bestaar af følgende, regnede fra neden opefter: Moræne A, det glaciofluviale hvide Sand a, Tellinaleret, det glaciofluviale Grus og Sand b, Moræne B, Moræne C, det glaciofluviale Grus og Sand c med Molluskskaller paa sekundært Leje, Moræne D. Naar undtages den vestlige Ende af Klinten (Afsnittene I-II), hvor Dannelserne synes at ligge i deres oprindelige, vandrette Stilling, er alle Aflejringerne undtagen Moræne D mere eller mindre stærkt forstyrrede: den oprindelig vandret liggende Serie er foldet og bristet paa Grund af et Tryk; nogle Steder er Stykkerne skudt over hverandre, saa de nu staar mere eller mindre stejlt, dog med Lagfølgen i den rigtige Orden. Først efter at Forstyrrelsen har fundet Sted, 
er Moræne D ved et nyt Isfremstød aflejret diskordant over de mere eller mindre udtværede Lagender og foroven afskaarne Folder.

For at faa Klarhed over, hvorledes disse Forstyrrelser er foregaaet, vil vi begynde med at betragte Tellinaleret i Parti V, Klintens største Tellinaler-Parti. Saavel dets uregelmæssige Underflade med de to nedadvendende Buer, som Pliséen og de opadbuede Lag i dets øvre Parti (se S. 55-56) viser, at dette Stykke er foldet ved et Sidetryk (3die og 4de Fold paa den skematiske Tegning, Fig. 25). Det er ikke svært at tænke sig dette Lerparti forbundet med Tellinaleret i Parti IV og III, der danner en nedadvendt Bue, hvis sydvestlige, opadstigende Gren løber tilspidset op over Moræne C i den sydvestlige Ende af Parti III. Forbindelsen mellem Leret i Parti V og Partierne IV og III har udgjort en "Saddel«, som forsvandt, da Christiansminde-Dalen dannedes ved Erosion. Mod Nordøst bøjer Tellinaleret sig nedad mod Stranden, som det naaer $144 \mathrm{~m}$ Nordøst for Christiansminde-Dalens dybeste Sted. Derover (d. v. s. Øst for det) følger Sandet b, samt Morænerne B og C, hvorefter følger en ny Flage af Tellinaler. Man kunde anse dettes Paalejring paa Oversiden af Moræne C som et Resultat af en simpel Overskydning, foranlediget ved et mere eller mindre lodret Brud af hele Lagserien; men ser man hen til de øvrige Forhold i Klinten, maa det betragtes som en opadvendende Fold, der er bristet i Toppunktet, og hvis vestlige, nedadvendende Gren — i alt Fald for det Stykkes Vedkommende, som skulde være oven Vande - er helt bortslidt under Overskydningen. Resten af Klinten hen til Grænsen mod det opskudte Plastiske Ler udgøres saa af en meget stor, nedadgaaende og efter den østlige Grens Tykkelse at dømme, sikkert temmelig dyb Fold. Kun i denne Fold (1ste Fold) — og endda kun i dens østlige Gren - kommer Moræne A tilsyne; hvis denne har deltaget i Foldningen af det øvrige Parti af Klinten, er den i alt Fald ikke bleven bragt oven Vande. At der navnlig i Tellinalerets nederste Del og i de underliggende veks. lende Ler- og Sandlag forekommer Smaaspring, undertiden saa talrige, at de sine Steder danner et breccieagtigt »Overgangslag", viser, at det ikke drejer sig om en simpel Bøjning af Lagene, men at saavel Tellinaleret som de underliggende tynde Ler- og Sandlag er gennemsatte af talrige, omtrent vinkelret paa Lagdelingen staaende Spalter, langs hvilke der under Foldningen er foregaaet Glidninger.

Aarsagen til Foldningen maa ganske givet søges i Opskydningen af det Plastiske Ler; den skyldes i alt Fald ikke noget direkte Istryk af en Indlandsis fra $\varnothing$ st. Af de Grunde, som er fremsatte paa Siderne 20-21, opfatter vi de Kræfter, som har bevirket Oppresningen af det Plastiske Ler, og dermed Foldningen af Kvartærlagene, som tektoniske. Vi er ikke blinde for den Forestilling, at Vægten af en meget anselig Ismasse, beliggende i Baaring Vig, der i sin Form nok kan lede Tanken 


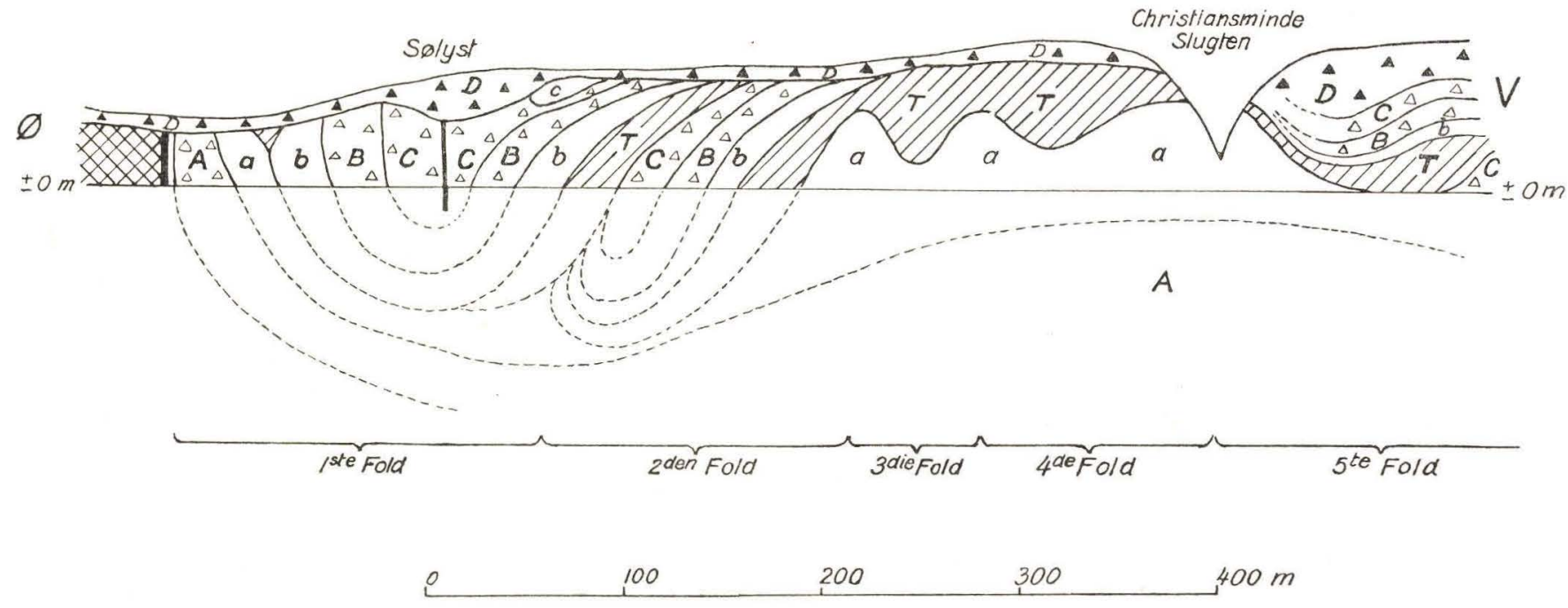

Fig. 25. Skematisk Profilskitse af Partierne IV-IX i Røgle Klint. Højde: Længde $=2: 1$. Foldningerne under 0-Linien (Havfladen) er hypotetiske. Fra Øst (til Venstre) Plastisk Ler (krydsskraveret), Glimmerler (sort), Glimmersand (hvidt), Morænerne A-D, de glaciofluviale Sand- og Gruslag a-c og Tellinaleret T,

Esquisse schématique du profil des parties IV-IX dans la falaise de Rögle. Hauteur: longueur $=2: 1$. Les plis sous la ligne 0 (au-dessous du niveau de la mer) sont hypothétiques. De l'est (à gauche) l'Argile plastique (grisée en quadrillé), l'Argile micacée (noire), le Sable micacé (blanc), les moraines A-D, les couches de sable et de gravier glacio-fluviaux a-c, et l'argile à Tellina $\mathrm{T}$. 
hen paa en Centraldepression, muligvis kunde frembringe de Forhold, som nu ses i Klinten (altsaa inklusive Oppresningen af det Plastiske Ler). Vi skal dog ikke her komme ind paa en nærmere detailleret Begrundelse af, hvorfor en saadan Tydning ikke har tiltalt os, men kun gøre opmærksom paa, at de Jordvolde, som koncentrisk skulde omkranse Gletsjerranden ligesaa lidt er paavist her som ved Halk Hoved og i Lønstrup og Ristinge Klinter. Dette kunde naturligvis skyldes, at de er bortfjernede af den senere fremrykkende Is, som har aflejret den øverste, diskordante Moræne D. Men i Røgle Klint har Fænomenet i alt Fald ikke haft den Udstrækning som paa de af Gripp skildrede Lokaliteter paa Spitsbergen. Ganske vist er paa den ligeoverfor liggende jyske Kyst det Plastiske Ler ligeledes løftet i Vejret, men Vest for dette iagttages ikke den regelmæssige, foldede Lagserie, ja Tellinaleret er end ikke paavist. Og i den parallelt med Klinten løbende Dal paa Røgle-Halvøen er der ikke iagttaget noget, som kunde tyde paa, at Foldningsfænomenet har strakt sig nævneværdigt mod Syd, hvad man burde vente, hvis der havde eksisteret lignende, koncentrisk oppressede Volde som de af Gripp iagttagne.

\section{Slutningsbemærkninger.}

\section{Af Victor Madsen.}

Det er ikke uden Betænkelighed, at vi udsender denne Monografi af Røgle Klint, for det er desværre endnu ikke lykkedes os at faa fuld Klarhed over Klintens mange indviklede geologiske Fænomener. Ved en Række Undersøgelser og Studier, som vi har foretaget i en lang Aarrække, og for hvilke der er gjort Rede i det foregaaende, mener vi dog, at vi omsider har fundet den endelige Løsning paa det vanskeligste Spørgsmaal, som Klinten stiller, hvad der er Aarsagen til Dislokationerne i den. Vi er kommet til det Resultat, at det er Hævningen af den Horst af Plastisk Ler, som findes Nordøst for Klinten, og det Tryk, som denne Hævning har foraarsaget, der har bevirket Sammenpresningen af Klinten med dens Følger: de Foldninger og Overskydninger, som kan iagtages i Klinten. Da vi er af den Formening, at det ikke er os muligt med de Midler, som vi raader over, at naa videre, end vi nu er kommet, har vi omsider besluttet os til at offentliggøre Resultatet af vore Arbejder.

Men der staar tilbage at foretage mekaniske, kemiske og petrografiske Analyser af Klintens forskellige Aflejringer, at udføre Bestemmelser af Mineralkornene i dens Moræner, og ikke mindst at faa afgjort - ved geofysiske Undersøgelser, — om der findes en Salthorst under det Plastiske Ler i Horsten Nordøst for Klinten, og at faa fuld Klarhed over Overskydningernes Natur, om de er Blok-Overskydninger (Schollenüberschiebungen), eller Fold-Overskydninger, som er fremkommet ved, at to af de hældende Folder er blevet forskudte saa 
meget, at Mellemfløjene mellem deres Sadler og Truge er blevet fuldstændig bortslidte. Det sidste betragter vi som det sandsynligste, idet Overskydningsfladerne, som er krumme og skæve, kun hælder 20-40

Paa den dislocerede Klintstrækning, Partierne IX-III, findes der 4 anselige Synklinaler (Truge) med 3 mellemliggende Antiklinaler (Sadler). Længst mod Øst, mellem »Glimmerlerkløften« og »Sølystkløften«, møder vi den østlige (venstre), lodrette Fløj af den første Synklinal (Nordmanns 1ste Fold i Fig. 25, S. 85). I denne Fløj er der mellem de glaciofluviale Lag a og b en Dislokation, paa hvilken Tellinaleret for største Delen er blevet slidt bort, saa at der kun er en lille Flage tilbage af det højt oppe i Klinten. Vest for »Sølystkløften " træffer vi den vestlige (højre) Fløj af den første Synklinal, i hvilken Tellinaleret imidlertid er velbevaret. Det er et Spørgsmaal, om der overhovedet findes en Dislokation i »Sølystkløften", om denne Kløft ikke snarere simpelt hen er opstaaet ved Erosion langs med Synklinalens Akseplan.

Den første Synklinals skraa Vestfløj gaar længere mod Vest over i den østlige Fløj af den første Antiklinal, hvis øverste Del er bortfjernet af den Indlandsis, som aflejrede Moræne D. Antiklinalen hælder mod NØ. Dens Vestfløj er slidt bort ved Overskydningen i Parti VI mellem Næserne 17 og 13.

Vest for Overskydningen (under den) møder man Vestfløjen af den næste, den anden Synklinal (Norduans 2den Fold i Fig. 25); dens Østfløj mangler, den er slidt bort ved Overskydningen.

Vestfløjen fortsætter sig opad i Østfløjen i den næste, den anden An tiklin a l, der som en »uftsaddel naar mod Øst over Christiansminde-Dalen til Parti IV. Grænsefladen mellem Tellinaleret og det underliggende glaciofluviale Sand a viser sig at være foldet i 3 sekundære Antiklinaler med 2 mellemliggende sekundære Synklinaler (NorDmanns 3die Fold og 4de Fold i Fig. 25).

Den anden Antiklinals Vestfløj fortsætter sig nedad (over Christiansminde-Dalen) i den østlige Fløj af den tredje Synklinal i Parti IV (Nordmanns 5te Fold i Fig. 25).

Denne Synklinals Vestfløj gaar over i den tredje Antiklin a Is Østfløj. I denne Antiklinal, Klintens vestligste, der ligesom den første Antiklinal hælder mod NØ, mangler, ligesom i den første Antiklinal, Vestfløjen; den er slidt bort i Overskydningen i Parti III.

Vest for denne Overskydning (under den) møder man Vestfløjen i den fjerde Synklinal, — dens Østfløj er borte ligesom Østfløjen i den anden Synklinal, den er slidt bort i Overskydningen. Vestfløjen, som med Undtagelse af den Del af Moræne C, der ses i Parti III, ligger under Havfladen, maa anses for at fortsætte sig i de horizontale Lag i Partierne II og I.

Vi har her fremsat den Opfattelse af Røgle Klints Bygning, som vi er kommet til ved vort mangeaarige Arbejde. 


\section{Dislokationernes \\ og Lagenes Strygninger og Hældninger.}

\section{Dislokationerne.}

\section{Parti IX.}

Plastisk Ler-Horstens Gransedislokation.

Inderst i Kløften foroven ..... N. $30^{\circ} \mathrm{V}$.

$70^{\circ} \mathrm{m} . \mathrm{S} .60^{\circ} \mathrm{V}$.

do. noget længere ude og nede . N. $50^{\circ} \mathrm{V}$.

$45^{\circ} \mathrm{m} . \mathrm{N} .40^{\circ} \varnothing$.

Lidt indenfor Kløftens Munding

over den horizontale Dislokation

N. $20^{\circ}$ V. $50-70^{\circ} \mathrm{m}$. N. $70^{\circ} \varnothing$.

Lidt indenfor Kløftens Munding under den horizontale Dislo-

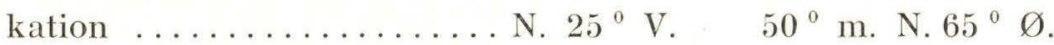

Dislokationen paa Tellinalerets Un-

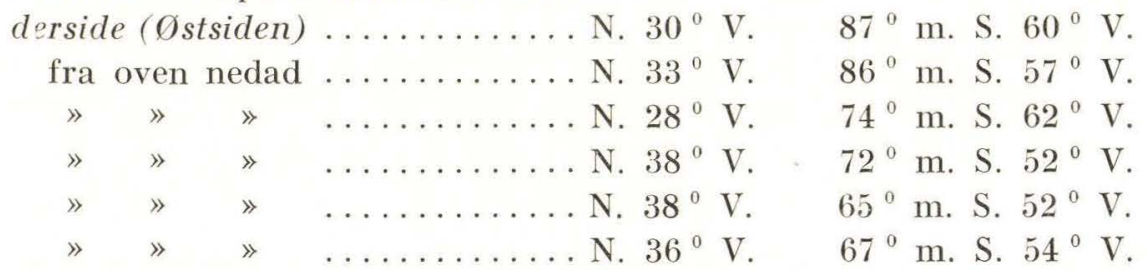

Dislokationen paa Tellinalerets

Overside (Vestsiden) . . . . . . N. $30^{\circ} \mathrm{V} . \quad 64^{\circ} \mathrm{m} . \quad \mathrm{N} .60^{\circ} \varnothing$.

i samme Højder som de foreg... N. $42^{\circ} \mathrm{V} . \quad 40^{\circ} \mathrm{m} . \mathrm{N} .48^{\circ} \varnothing$.

\begin{tabular}{|c|c|c|c|c|c|}
\hline$\gg$ & 》 & $»$ & $»$ & .. N. $45^{\circ} \mathrm{V}$. & $82^{\circ} \mathrm{m} . \mathrm{N} .45^{\circ} \varnothing$. \\
\hline » & $\gg$ & $\gg$ & 》 & .. N. $50^{\circ} \mathrm{V}$. & $60^{\circ} \mathrm{m} . \quad$ N. $40^{\circ} \varnothing$. \\
\hline & » & $\gg$ & » & .. N. $43^{0} \mathrm{~V}$. & $70^{\circ} \mathrm{m} . \mathrm{N} .47^{\circ} \varnothing$. \\
\hline & » & (y) & 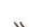 & $N=50^{0}$ & $\mathrm{~N}-40^{\circ}$ \\
\hline
\end{tabular}

Dislokationen under Tellinalerfla-

gen

ved Flagens Spids $\ldots \ldots \ldots \ldots$ N. $37^{\circ}$ V. $88-90^{\circ}$ m. N. $53^{\circ} \varnothing$.

$9 \mathrm{~m} \mathrm{o.} \mathrm{H.} \mathrm{\ldots \ldots .......} 35^{0} \mathrm{~V} . \quad 72^{\circ} \mathrm{m} . \mathrm{N} .55^{\circ} \varnothing$ 


\section{Parti VI.}

Dislokationen mellem Tellinaleret

og Morcene C.

Hældning

$18 \mathrm{~m} \mathrm{o.} \mathrm{H}$

N. $57^{\circ} \mathrm{V}$.

$40^{\circ} \mathrm{m}$. N. $33^{0} \varnothing$.

$1,7 \mathrm{~m}$ højere oppe og $2,5 \mathrm{~m}$ længere inde $\ldots \ldots \ldots$ N. $70^{\circ} \mathrm{V} . \quad 30^{\circ} \mathrm{m} . \quad$ N. $20^{\circ} \varnothing$.

2,0 $\mathrm{m}$ højere oppe og $3,7 \mathrm{~m}$ længere inde $\ldots \ldots \ldots$ N. $40^{\circ} \mathrm{V} . \quad 25^{\circ} \mathrm{m} . \quad$ N. $50^{\circ} \varnothing$.

tretved, hvor Tellinaleret kiler

sig ud .............. $54^{0} \mathrm{~V}$.

$35^{\circ} \mathrm{m}$. N. $36^{\circ} \varnothing$.

Dislokationen over Tellinaleret.. N. $80^{\circ} \mathrm{V}$.

$30^{\circ} \mathrm{m}$. N. $10^{\circ} \varnothing$.

\section{Parti V.}

Dislokation mellem Stenlaget $b$ og

Tellinaleret $\ldots \ldots \ldots \ldots \ldots \ldots \ldots \ldots \ldots .65^{\circ} \mathrm{V} . \quad 20^{\circ} \mathrm{m} . \mathrm{N} .5^{\circ} \varnothing$.

\section{Parti IV.}

Dislokation mellem Sandet a og de

tynde Ler- og Sandlag forneden $i$

Tellinaleret ............

\section{Parti III.}

Dislokationen over Morcene C.

$16 \mathrm{~m} \mathrm{o.} \mathrm{H.} \mathrm{\ldots \ldots \ldots \ldots \ldots .......} 55^{\circ} \mathrm{V}$

$40^{\circ} \mathrm{m} . \quad$ N. $35^{\circ} \varnothing$.

Nogle Meter højere oppe ..... N. $40^{\circ} \mathrm{V}$.

$30^{\circ} \mathrm{m}$. N. $50^{\circ} \varnothing$.

Atter nogle Meter højere oppe .. N. $30^{\circ} \mathrm{V}$.

$25^{\circ} \mathrm{m}$. N. $60^{\circ} \varnothing$.

Grænsefladen mellem Stenlaget b

og de med dette følgende tynde

Lerlag og det øverste af de un-

derliggende Sandlag. NØ. f. Tel-

linalerfremspringet $\ldots \ldots \ldots$ N. $\quad 5^{\circ} \mathrm{V} . \quad 38^{\circ} \mathrm{m} . \quad$ N. $85^{\circ} \varnothing$.

Længere mod SV. paa den syd-

vestlige Side af Tellinalerfrem-

springet. Grænsefladen mellem

Stenlaget b og Tellinaleret .... N. $45^{\circ} \varnothing . \quad 20^{\circ} \mathrm{m} . \mathrm{S} .45^{\circ} \varnothing$.

\section{Parti V.}

\section{Lillebeltspring.}

Den tidligere Nedgang fra Chri-

stiansminde Dalen $9 \mathrm{~m}$ o. H.

$55 \mathrm{~m}$ NØ. for Dalbunden..... N. $25^{\circ} \varnothing . \quad 80^{\circ} \mathrm{m} . \mathrm{S} .65^{\circ} \varnothing$.

I det 1931 dannede Profil, som vendte $\bmod$ Nord $\ldots \ldots \ldots \ldots$ N. $2^{\circ} \varnothing . \quad 70^{\circ} \mathrm{m} . \mathrm{S} .88^{\circ} \varnothing$. omtrent midt i dette Profil ..... N. $4^{\circ} \varnothing . \quad 70^{\circ} \mathrm{m} . \quad$ N. $86^{\circ} \mathrm{V}$.

\section{Parti IV.}

Ved Tellinalerets Bøjning opad .. N. $70^{\circ} \varnothing . \quad 65^{\circ} \mathrm{m} . \quad \mathrm{N} .20^{\circ} \mathrm{V}$. 


\section{Parti IX.}

\section{Lagene.}

Tyndt Lag af Glimmersand Ø. f. Strygning

Hældning

meget stejl.

Moræne A. ............. N. $35^{0} \mathrm{~V}$

Zone mellem Moræne A og de gla-

ciofluviale Lag a:

Morænelerstribe tæt ved Moræne A. $\ldots \ldots \ldots \ldots \ldots \ldots$ N. $34^{0} \mathrm{~V} . \quad 85^{\circ} \mathrm{m} . \quad \mathrm{N} .56^{\circ} \varnothing$.

Sandlag længere mod Vest $\ldots$. N. $31^{\circ} \mathrm{V} . \quad 84^{\circ} \mathrm{m} . \quad$ N. $59^{\circ} \varnothing$.

Tyndt Lerlag endnu længere $\bmod$ Vest $\ldots \ldots \ldots \ldots \ldots$ N. $28^{\circ} \mathrm{V} . \quad 86^{\circ} \mathrm{m} . \mathrm{S} .62^{\circ} \mathrm{V}$.

Tyndt Lerlag endnu længere $\bmod$ Vest $\ldots \ldots \ldots \ldots \ldots \ldots \ldots \ldots \ldots{ }^{\circ} \mathrm{V} . \quad 85^{\circ} \mathrm{m} . \mathrm{S} .64^{0} \mathrm{~V}$.

1913 Sandlagene a ........ N. 20-45 ${ }^{\circ} \mathrm{V}$. meget stejl.

$19312 \mathrm{~m} \varnothing$ st f. Tellinalerflagen N. $66^{\circ} \mathrm{V}$. c. $37^{\circ} \mathrm{m} . \mathrm{N} .24^{\circ} \varnothing$. $6 \mathrm{~m} \gg \quad$ N. $60^{\circ} \mathrm{V} . \quad 34^{\circ} \mathrm{m} . \mathrm{N} .30^{\circ} \varnothing$. $8 \mathrm{~m} \gg \quad$ N. $54^{\circ} \mathrm{V} . \quad 43^{\circ} \mathrm{m} . \mathrm{N} \cdot 36^{\circ} \varnothing$. $9 \mathrm{~m} \gg \quad$ N. $58^{\circ} \mathrm{V} .48^{\circ} \mathrm{m} . \quad \mathrm{N} .32^{\circ} \varnothing$. Midt i Tellinaleret ..... N. $30^{\circ} \mathrm{V} . \quad 86^{\circ} \mathrm{m} . \mathrm{S} .60^{\circ} \mathrm{V}$. De glaciofluviale Lag $\mathbf{b}$.

$19130,5 \mathrm{~m}$ fra Østgrænsen .. N. $40^{\circ} \mathrm{V}$. omtrent lodret.

$1 \mathrm{~m}$ fra Østgrænsen .. N. $48-50^{\circ} \mathrm{V} . \quad » \quad »$ længere borte ....... N. $34^{0} \mathrm{~V} . \quad »$ endnu længere borte .... N. $37^{\circ} \mathrm{V}$. »

$193115 \mathrm{~m} \mathrm{o.} \mathrm{H.}$ $80^{\circ} \mathrm{m}$. N. $40^{\circ} \varnothing$. $40 \mathrm{~cm} \gg \gg \quad$ N $\quad 52^{\circ} \mathrm{V} . \quad 86^{\circ} \mathrm{m} . \mathrm{S} .38^{\circ} \mathrm{V}$. $46 \mathrm{~cm} \gg \gg \quad » \quad$ N. $52^{\circ} \mathrm{V} . \quad 84^{\circ} \mathrm{m} . \mathrm{S} \cdot 38^{\circ} \mathrm{V}$. $62 \mathrm{~cm} \gg \gg \quad$ N. $54^{0} \mathrm{~V} . \quad 74^{\circ} \mathrm{m} . \mathrm{S} \cdot 36^{0} \mathrm{~V}$. $102 \mathrm{~cm} \gg \gg \quad$ N. $39^{\circ} \mathrm{V} . \quad 79^{\circ} \mathrm{m} . \mathrm{S} .51^{0} \mathrm{~V}$. $16 \mathrm{~m} \mathrm{o.} \mathrm{H.}$

$17 \mathrm{~cm}$ Vest for Tellinalerflagen N. $37^{\circ} \mathrm{V} . \quad 89^{\circ} \mathrm{m} . \mathrm{N} .53^{\circ} \varnothing$. $21 \mathrm{~cm} » " \quad$ N. $42^{\circ} \mathrm{V} . \quad 82^{\circ} \mathrm{m} . \mathrm{N} \cdot 48^{\circ} \varnothing$. $32 \mathrm{~cm} » \quad$ » $» 44^{\circ} \mathrm{V} .75^{\circ} \mathrm{m} . \mathrm{N}, 46^{\circ} \varnothing$. $95 \mathrm{~cm} » \gg \quad$ N. $28^{\circ} \mathrm{V}$. $78^{\circ} \mathrm{m} . \mathrm{S} .62^{\circ} \varnothing$.

Moræne B. Sandsmøre i den nedre Del $\ldots \ldots \ldots \ldots \ldots$ N. $23^{\circ} \mathrm{V} . \quad 88^{\circ} \mathrm{m} . \quad \mathrm{N} .67^{\circ} \varnothing$.

Moræne B. Tyndt Lerlag i Sand i den øvre Del . . . . . . . N. $35^{\circ} \mathrm{V} . \quad 80^{\circ} \mathrm{m} . \mathrm{N} .55^{\circ} \varnothing$.

\section{Parti V.}

I nicheformet Udgravning $10 \mathrm{~m}$

o. H.

Tellinalerets Underflade i:

NØ.-Siden $\ldots \ldots \ldots \ldots \ldots \ldots$ N. $80^{\circ} \mathrm{V} . \quad 25^{\circ} \mathrm{m} . \mathrm{N} \cdot 10^{\circ} \varnothing$. 
Strygning Hældning

SV.-Siden $\ldots \ldots \ldots \ldots \ldots \ldots$ N. $70^{\circ} \varnothing . \quad 10^{\circ} \mathrm{m} . \quad$ N. $20^{\circ} \mathrm{V}$.

Nordøstsiden af nordøstlige Saddel

Tellinalerets Underflade $9,3 \mathrm{~m}$.

o. H. $\ldots \ldots \ldots \ldots \ldots \ldots \ldots$ N. $38^{\circ} \mathrm{V} . \quad 40^{\circ} \mathrm{m} . \quad$ N. $52^{\circ} \varnothing$.

Tellinalerets Underflade $9,8 \mathrm{~m}$

o. H. . . . .

Nordøstsid. af mellemste Saddel

Tellinalerets Underflade $7,5 \mathrm{~m}$

o. H. …

Tellinalerets Underflade $14 \mathrm{~m}$

o. H. …...... N. $58^{0} \mathrm{~V} . \quad 77^{\circ} \mathrm{m} . \mathrm{S} .32^{0} \mathrm{~V}$.

Lagene i Tellinaleret ..... N. $42^{\circ} \mathrm{V} . \quad 38^{\circ} \mathrm{m} . \quad \mathrm{N} \cdot 48^{0} \varnothing$.

Sydvestsid. af mellemste Saddel

Tellinalerets Underflade $16 \mathrm{~m}$

o. H. … . . $58^{\circ} \mathrm{m} . \mathrm{S} .48^{\circ} \mathrm{V}$.

Tellinalerets Lag $\ldots \ldots \ldots \ldots$ N. $30^{\circ} \mathrm{V} .14-16^{\circ} \mathrm{m} . \mathrm{S} .60^{\circ} \mathrm{V}$.

Tellinalerets Underflade $14 \mathrm{~m}$

o. H. . . . . $39^{\circ} \mathrm{m} . \mathrm{S} .80^{\circ} \mathrm{V}$.

Tellinalerets Lag $\ldots \ldots \ldots \ldots$ N. $14^{\circ} \mathrm{V} . \quad 36^{\circ} \mathrm{m} . \mathrm{S} .76^{\circ} \mathrm{V}$.

\section{Parti IV.}

Underfladen af det opadbøjede

Tellinaler.

$8,5 \mathrm{~m} \mathrm{o.} \mathrm{H.} \ldots \ldots \ldots \ldots \ldots$ N. $55^{0} \mathrm{~V} . \quad 76^{0} \mathrm{~m} . \mathrm{S} .35^{0} \mathrm{~V}$.

$9,5 \mathrm{~m} \mathrm{o} . \mathrm{H} . \ldots \ldots \ldots \ldots \ldots \ldots$ N. $22^{0} \mathrm{~V} . \quad 87^{\circ} \mathrm{m} . \mathrm{S} .67^{\circ} \mathrm{V}$.

$10,4 \mathrm{~m} \mathrm{o.} \mathrm{H.} \mathrm{.} \mathrm{.} \mathrm{.} \mathrm{.} \mathrm{.} \mathrm{.} \mathrm{.} \mathrm{.} \mathrm{.} 59^{\circ} \mathrm{V} . \quad 64^{\circ} \mathrm{m} . \mathrm{N} .31^{\circ} \varnothing$.

$12,5 \mathrm{~m} \mathrm{o.} \mathrm{H.} \mathrm{............} \mathrm{N.} 30^{\circ} \mathrm{V} . \quad 40^{\circ} \mathrm{m} . \mathrm{N} \cdot 60^{\circ} \varnothing$.

Gruslaget b ved den store Sten N. $80^{\circ} \varnothing . \quad 30^{\circ}$ m. S. $10^{\circ} \varnothing$.

Ser man bort fra Lillebeltspringene, der først er fremkomne efter Sammenskydningen af Lagene i Røgle Klint og saaledes ikke har noget at gøre med Sammenskydningen, ligger Dislokationernes og Lagenes 72 maalte Strygninger mellem N. $5^{\circ} \mathrm{V}$. og N. $85^{\circ} \mathrm{V}$. med Undtagelse af 3 , som har Retningerne N. $45^{\circ} \varnothing$., N. $70^{\circ} \varnothing$. og N. $80^{\circ} \varnothing$. Udelades disse 3, samt de meget stejle Sandlag a i Parti IX (S. 90) med Strygningen N. 20-45 ${ }^{\circ}$ V., faas som Middeltal af Dislokationernes 29 Strygninger N. $42^{\circ}$ V., og som Middeltal af Lagenes 39 Strygninger ogsaa N. $42^{\circ}$ V. Man kan deraf drage den Slutning, at den sammenskydende Kraft, der fremkom ved Horstens Hævning, har haft Retning fra N. $48^{\circ} \varnothing . \bmod S .48^{\circ} \mathrm{V}$. 


\section{Stentællinger.}

Cærlig ved Detailundersøgelserne af Røgle Klint i 1913-14, men ogsaa D i Aarene 1912 og 1915 toges en Mængde Prøver af de i Klinten forekommende Moræner, for deri at udføre Stentællinger efter den i Beskrivelsen til Kortbladet Hindsholm angivne Metode ${ }^{38}$ ), der som objektiv Metode til Adskillelse af de forskellige Moræneler-Aflejringer i en Aarrække er bleven anvendt af Danmarks Geologiske Undersøgelse. $10 \mathrm{~kg}$ lufttørret Moræneler vaskes gennem en Sigte med kvadratiske Masker, hvis Side er $6 \mathrm{~mm}$. Af de Sten, som bliver tilbage i Sigten, borttages de faa, som er større end et Hønseæg. Resten vejes, bestemmes, tælles, og Procentmængden af de forskellige Stenarter beregnes. Derefter beregnes Stentællingskvotienten, som er Antallet af Flint divideret med Antallet af krystallinske Bjergarter. Denne Kvotient har nemlig vist sig at være tilnærmelsesvis den samme for Stentællinger, udførte i samme Moræneler-Aflejring i samme Egn. Af de fundne Stentællingskvotienter beregnes Middeltallet og den sandsynlige Middelfejl paa dette. Derved faas et Tal, som karakteriserer den paagældende Moræneaflejring i den paagældende Egn. Resultaterne af de 116 Stentællinger, som er foretagne i Morænerne i Røgle Klint, er anførte i Tabellerne S. 96-103. De er udførte af E. M. NørregaArd, medens Sigurd Hansen har ydet værdifuld Hjælp ved Beregningerne.

Moræne A, fra den første danske Istid, forekommer i Røgle Klint kun i Parti IX, Vest for de tertiære Aflejringer. Den er blaasort eller sortebrun af Farve og indeholder sine Steder talrige Sandsmører. Den har som Middeltal af 8 Stentællingskvotienter givet $0,36 \pm 0,044$.

Moræne B, fra den anden danske Istid, bestaar forneden, $B_{1}$, overvejende af graabrunt, sandet Moræneler, hvori der findes Bænke, til hvilke Glimmerler aabenbart har leveret meget Materiale. Den øvre Del $\mathrm{B}_{2}$ kan være brun, men den kan ogsaa være blaagraa og adskilligt federe; den kan indeholde Lag og Indlejringer af stenfrit Ler, Sand og Grus.

$\mathrm{B}_{1}$ forekommer i Røgle Klint kun i Parti IX Vest for Forchhammers Lag. Den har som Middeltal af 7 Stentællingskvotienter givet $0,50 \pm$ 0,049 . 
$\mathrm{B}_{2}$ forekommer i Partierne III-VII og i Parti IX. I Parti III har 3 Stentællinger i brunt Moræneler givet Middeltallet $0,84 \pm 0,041$. I Parti VI har 12 Stentællinger, de fleste i brunt Moræneler, givet $0,82 \pm 0,044$. I Parti VII har 10 Stentællinger, de fleste i brunt Moræneler, givet $0,82 \pm 0,051$. 5 Stentællinger i Parti IX har givet $0,83 \pm$ 0,085. Samtlige 30 Stentællinger i $B_{2}$ har givet $0,82 \pm 0,026$.

Moræne $\mathbf{C}$, fra den tredje danske Istid, bestaar overvejende af Moræneler, der i uforvitret, tør Tilstand ser ud som almindeligt blaat Moræneler; i fugtig Tilstand har Farven en ejendommelig sort Tone, som antagelig skyldes en Indblanding af Glimmerler. Beskaffenheden er dog varierende; i de østlige Partier af Klinten er Moræne C lysblaagraat, meget fedt Moræneler, der snart kan være saa godt som stenfrit, snart meget stenrigt. De foretagne Stentællinger viser, at Moræne $\mathrm{C}$ ligesom Moræne $\mathrm{B}$ maa deles $\mathrm{i}$ en nedre Del $\mathrm{C}_{1}$ og en øvre Del $\mathrm{C}_{2}$.

$\mathrm{C}_{1}$ forekommer i Partierne III-IX. I Parti III har 2 Stentællinger i graabrunt og i blaat Moræneler givet Middeltallet 0,52 $\pm 0,026$. I Parti VI har 6 Stentællinger i blaat Moræneler givet Middeltallet $0,47 \pm 0,025$. I Parti VII har 4 Stentællinger i blaat Moræneler og 3 i rødt Moræneler givet Middeltallet $0,52 \pm 0,014$. I Parti IX har 3 Stentællinger givet Middeltallet $0,46 \pm 0,022$. Samtlige 18 Stentællinger $\mathrm{i}_{1}$ har givet $0,49 \pm 0,012$.

$\mathrm{C}_{2}$ danner den nedre Moræne paa en Strækning af en $300 \mathrm{~m}$ i »Sandprofilet« (Parti I). Den forekommer endvidere i Partierne III-IX, hvor vi ved Undersøgelserne kaldte den Krydsmorænen. I Parti III har 5 Stentællinger i rødbrunt Moræneler givet $0,71 \pm 0,026$. I Parti VI har 2 Stentællinger i blaat Moræneler givet $0,77 \pm 0,02$. I Parti IX har 3 Stentællinger i blaat Moræneler givet $0,85 \pm 0,047$.

Da der var en ypperlig Lejlighed til at undersøge, hvorledes Stentællingerne kan variere indenfor den samme Moræne, toges 191533 Prøver af den nedre Moræne i »Sandprofilet « (Parti I) i Afstande af henholdsvis $4,20,40,60,80,120,160,200,220,240$ og $280 \mathrm{~m}$ fra det Sted i Klintens Vestende, hvor den nedre Moræne kommer til Syne, hvert Sted 3 Prøver lodret over hinanden med regelmæssige Mellemrum. Resultaterne af de i disse Prøver foretagne Stentællinger findes i Tabellen S. 100 under Løbenumrene 77-109. De er grafisk fremstillede i Fig. 26, S. 94. De viser, at Stentællingskvotienterne varierer mellem 0,42 og 1,86. Deres Middeltal er 0,91 $\pm 0,022$. Kasseres de tre højeste Stentællingskvotienterne, Nr. 106 1,60, Nr. 97 1,77 og Nr. 96 1,86, som abnorme, f. Eks. ved, at en Flintesten er gaaet i Stykker, faas, at Variationen ligger mellem 0.42 og 1,37. Middeltallet bliver da $0,83 \pm 0,056$.

Tidligere var der taget 3 Stentællinger i den nedre Moræne i Sand- 
profilet. Disse 3 gav som Middeltal $0,70 \pm 0,123$. Medtages disse, faas som Middeltal af de 36 Stentællingskvotienter $0,90 \pm 0,066$.

Samtlige 46 Stentællinger i $\mathrm{C}_{2}$ har givet $0,87 \pm 0,051$. Kasseres, ligesom ovenfor, de 3 højeste Stentællinger som abnorme, faas for Moræne $\mathrm{C}_{2}$ af de 43 Stentællingskvotienter Middeltallet $0,81 \pm 0,04$.

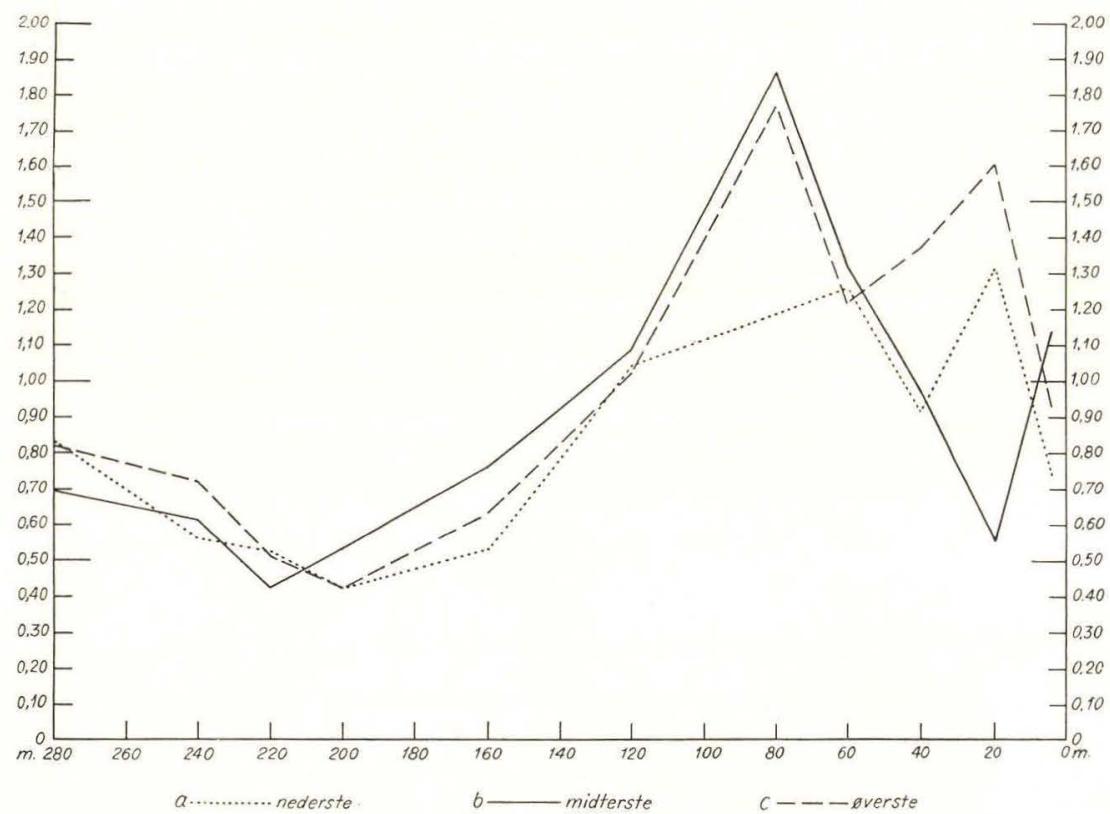

Fig. 26. Grafisk Fremstilling af Resultaterne af de 33 Stentællinger, som i 1915 foretoges i Moræne $\mathrm{C}_{2}$ i »Sandprofilet« i Parti I. De udførtes ved, at der i Afstandene 4, 20, 40, 60, 80, 120, 160, 200, 240 og $280 \mathrm{~m}$ fra det Sted i Klintens Vestende, hvor Moræne $\mathrm{C}_{2}$ først kommer til Syne, hvert Sted toges 3 Prøver lodret over hinanden med regelmæssige Mellemrum. I Figuren angiver Abscisserne Afstandene i Meter mellem de udtagne Prøver. Ordinaterne angiver Størrelsen af Stentællingskvotienterne. Disse er opførte i Tabellen S. 100-103 under Løbenumrene 77-109. Kurverne angiver de nederste, de mellemste og de øverste Prøver.

Représentation graphique des résultats des 33 énumérations de blocs, qui, en 1915, furent entreprises dans la moraine $C_{2}$ du "profil de sable dans partie I. Elles furent exécutées de la manière suivante. Trois échantillons furent pris verticalement les uns sur les autres, avec des espaces intermédiaires réguliers, à des distances de 4, 20, 40, $60,80,120,160,200,240$ et $280 \mathrm{~m}$, du point dans le bout occidental de la falaise, où la moraine $\mathrm{C}_{2}$ fait sa première apparition. Dans la figure, les abscisses démontrent les distances en mètres entre les échantillons pris. Les ordonnées marquent les quotients des énumérations des blocs. Ceux-ci se trouvent, dans le tableau page 100-103, dans les numéros d'ordre 77-109. Les courbes indiquent les échantillons du bas, du milieu et du haut.

Moræne D, fra det østjydske Isfremstød under den tredje danske Istid, forekommer i »Sandprofilet « (Parti I) ved Overfladen som Rester af forvitret Moræneler med en Mægtighed af indtil $2 \mathrm{~m}$. I de østlige 
Partier optræder den som temmelig fedt og stift Moræneler med anselige Smører eller udtværede Partier af Plastisk Ler.

3 Stentællinger i Morænen øverst i Sandprofilet har givet som Middeltal 1,28 \pm 0,098. 4 Stentællinger i de østlige Partier har givet 1,18 0,051 . Samtlige 7 Stentællinger har givet $1,22 \pm 0,050$.

Det er interessant at sammenholde dette Middeltal med Middeltallet af Stentællingskvotienterne i de 15 Stentællinger, som er udførte i Moræne D i Ristinge Klint paa Langeland, 1,20 $\pm 0,119$. Overensstemmelsen mellem de to Middeltal er saaledes meget stor, Differencen mellem dem er mindre end Middelfejlen. De paa Fyn udførte Stentællinger viser, at Moræne D indtager hele Nord- og Midt-Fyn indenfor Vandskellene mellem de Aaer, som løber til Kattegat og Odense Fjord, og de Aaer, som løber til Belterne. Moræne D's Stentællingskvotient er paa Fyn, som Resultat af 116 Stentællinger 1,29 \pm 0,032.

Mellem Moræne C i Ristinge Klint med Stentællingskvotienten 0,68 \pm 0,064 (15 Bestemmelser) og Moræne $\mathrm{C}_{2}$ i Røgle Klint med Stentællingskvotienten $0,81 \pm 0,040$ (43 Bestemmelser) er Overensstemmelsen mindre stor. Større er Overensstemmelsen mellem denne Moræne og Moræne C i det sydlige Jylland indenfor det Omraade, hvor Overflademorænen maa anses for at være Moræne $\mathrm{C}_{2}$, hvis 57 Stentællinger har givet $0,88 \pm 0,047$, medens de 23 Stentællinger, som er udførte paa Kortbladet Bække i de Egne, hvor den øverste Moræne maa anses for at være Moræne $\mathrm{C}_{2}$ har givet $0,82 \pm 0,056$.

Mellem Moræne $\mathrm{B}_{2}$, fra den anden Istid, i Røgle Klint med Stentællingskvotienten $0,82 \pm 0,026$ (30 Bestemmelser) og Overflademorænerne fra den anden Istid paa de vestjydske Kortblade Varde og Bække med Stentællingskvotienten $0,84 \pm 0,057$ (32 Bestemmelser) er Overensstemmelsen ogsaa meget stor. 
Stentællings-

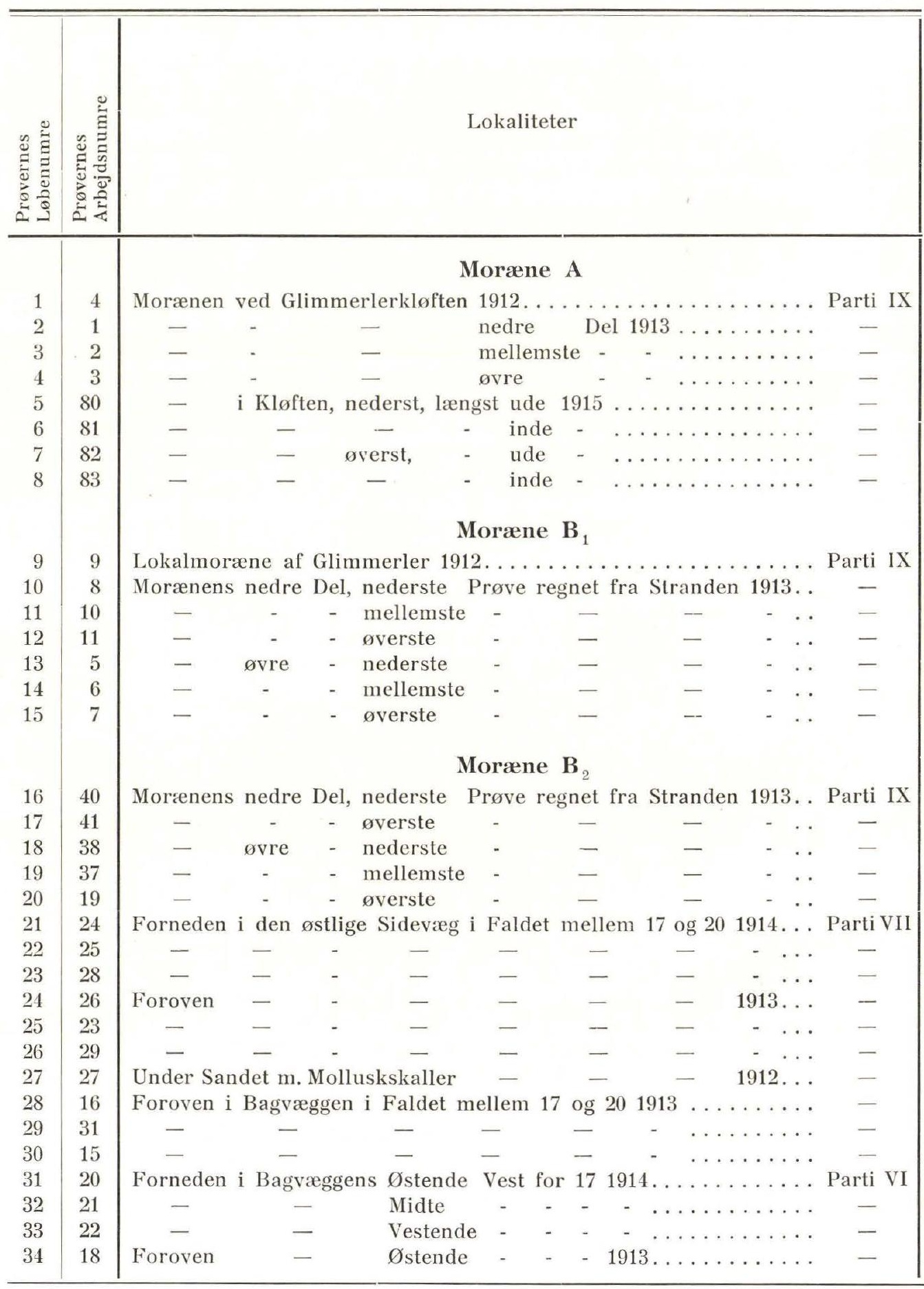




\section{Tabel.}

\begin{tabular}{|c|c|c|c|c|c|c|c|c|c|c|c|c|c|}
\hline 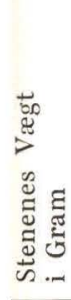 & 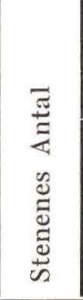 & 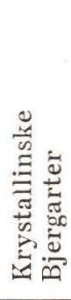 & 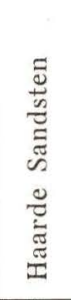 & 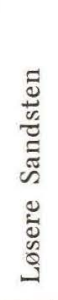 & 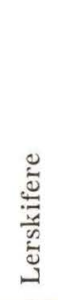 & 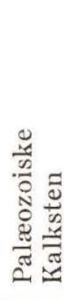 & 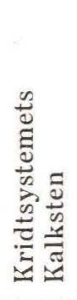 & $\vec{\Xi}$ & 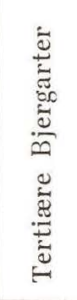 & 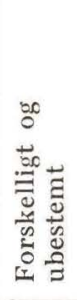 & 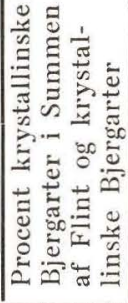 & 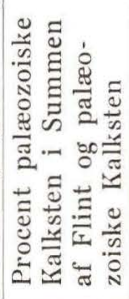 & 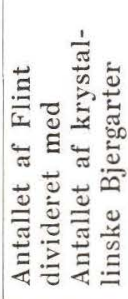 \\
\hline 549 & 297 & 52,2 & 10,8 & 4,4 & 1,0 & 7,1 & 6,7 & 15,1 & 2,7 & 0,0 & 77,5 & 31,8 & 0,29 \\
\hline 173 & 158 & 41,8 & 8,2 & 3,8 & 1,3 & 8,8 & 10,1 & 22,2 & 3,8 & 0,0 & 65,3 & 28,5 & 0,53 \\
\hline 807 & 461 & 47,5 & 10,0 & 3,3 & 1,3 & 10,6 & 13,0 & 13,9 & 0,4 & 0,0 & 77,4 & 43,4 & 0,29 \\
\hline 443 & 284 & 51,4 & 6,7 & 0,7 & 2,1 & 11,6 & 10,6 & 15,8 & 0,7 & 0,4 & 76,4 & 42,3 & 0,31 \\
\hline 095 & 524 & 49,3 & 13,0 & 1,7 & 1,5 & 12,0 & 4,0 & 12,2 & 2,5 & 3,8 & 80,2 & 49,6 & 0,25 \\
\hline 722 & 454 & 47,8 & 13,6 & 0,9 & 1,1 & 13,2 & 4,0 & 13,2 & 4,0 & 2,2 & 78,4 & 50,0 & 0,28 \\
\hline 287 & 96 & 43,8 & 8,4 & 5,2 & 1,0 & 3,1 & 10,4 & 20,8 & 4,2 & 3,1 & 67,8 & 13,0 & 0,48 \\
\hline 96 & 100 & 37,0 & 4,0 & 2,0 & 1,0 & 10,0 & 21,0 & 18,0 & 6,0 & 1,0 & 67,4 & 35,8 & 0,49 \\
\hline 592 & 273 & 56,4 & 15,0 & 2,2 & 0,7 & 0,0 & 0,0 & 24,6 & 0,0 & 1,1 & 69,7 & 0,0 & 0,44 \\
\hline 538 & 304 & 46,7 & 10,5 & 2,3 & 0,0 & 1,7 & 16,1 & 21,1 & 1,3 & 0,3 & 68,9 & 7,25 & 0,45 \\
\hline 425 & 265 & 49,8 & 11,3 & 1,9 & 0,8 & 5,2 & 9,1 & 19,6 & 1,9 & 0,4 & 71,7 & 21,2 & 0,39 \\
\hline 450 & 294 & 44,6 & 17,0 & 2,4 & 0,7 & 0,0 & 0,0 & 34,3 & 0,7 & 0,3 & 56,5 & 0,0 & 0,77 \\
\hline 440 & 269 & 52,1 & 15,2 & 1,9 & 0,7 & 3,0 & 4,5 & 21,9 & 0,7 & 0,0 & 70,4 & 11,9 & 0,42 \\
\hline 345 & 211 & 49,3 & 12,8 & 2,4 & 0,0 & 2,8 & 6,2 & 25,1 & 0,5 & 0,9 & 66,2 & 10,1 & 0,51 \\
\hline 362 & 238 & 45,8 & 8,8 & 3,4 & 0,0 & 5,4 & 9,7 & 25,2 & 1,7 & 0,0 & 64,5 & 17,8 & 0,55 \\
\hline 223 & 141 & 37,6 & 9,9 & 1,4 & 1,4 & 2,9 & 14,2 & 30,5 & 2,1 & 0,0 & 55,2 & 8,5 & 0,81 \\
\hline 233 & 190 & 45,8 & 9,5 & 2,1 & 1,1 & 3,7 & 10,5 & 24,7 & 2,6 & 0,0 & 64,9 & 12,9 & 0,54 \\
\hline 312 & 156 & 30,1 & 7,1 & 1,3 & 0,0 & 4,5 & 21,2 & 32,0 & 2,5 & 1,3 & 48,4 & 12,3 & 1,06 \\
\hline 238 & 169 & 29,6 & 10,7 & 0,6 & 0,5 & 6,5 & 25,4 & 24,9 & 1,8 & 0,0 & 54,3 & 20,7 & 0,84 \\
\hline 196 & 158 & 31,7 & 12,6 & 1,3 & 0,6 & 5,1 & 19,0 & 29,1 & 0,6 & 0,0 & 52,1 & 14,8 & 0,92 \\
\hline 200 & 171 & 36,2 & 10,5 & 0,0 & 0,0 & 3,5 & 12,3 & 34,5 & 1,2 & 1,8 & 51,2 & 9,2 & 0,95 \\
\hline 240 & 153 & 41,2 & 12,4 & 1,3 & 0,7 & 3,9 & 13,1 & 25,5 & 0,0 & 1,9 & 61,8 & 13,3 & 0,62 \\
\hline 272 & 139 & 44,6 & 11,5 & 0,7 & 0,0 & 4,3 & 10,1 & 27,4 & 0,0 & 1,4 & 62,0 & 13,6 & 0,61 \\
\hline 338 & 263 & 37,7 & 8,0 & 1,9 & 0,0 & 1,9 & 13,3 & 35,7 & 1,1 & 0,4 & 51,3 & 5,1 & 0,95 \\
\hline 712 & 388 & 40,5 & 8,5 & 1,3 & 0,0 & 3,9 & 8,7 & 34,5 & 1,8 & 0,8 & 53,9 & 10,1 & 0,85 \\
\hline 350 & $>201$ & 34,3 & 12,9 & 3,5 & 0,0 & 2,0 & 13,9 & 30,9 & $>2,0$ & 0,5 & 52,7 & 6,1 & 0,89 \\
\hline 685 & 324 & 33,3 & 9,6 & 2,5 & 0,0 & 1,6 & 11,7 & 39,5 & 0,3 & 1,5 & 45,76 & 3,8 & 1,09 \\
\hline 470 & 267 & 37,1 & 9,4 & 1,9 & 0,0 & 1,9 & 17,2 & 28,8 & 3,7 & 0,0 & 56,3 & 6,1 & 0,78 \\
\hline 405 & $>187$ & 42,8 & 9,6 & 2,7 & 0,0 & 4,8 & 13,4 & 26,7 & 0,0 & 0,0 & 61,5 & 15,3 & 0,63 \\
\hline 734 & 378 & 44,7 & 8,5 & 1,9 & 0,0 & 0,5 & 1,9 & 36,7 & 5,3 & 0,5 & 54,9 & 1,4 & 0,82 \\
\hline 316 & 245 & 50,2 & 12,3 & 0,8 & 0,0 & 1,7 & 6,9 & 26,9 & 0,0 & 1,2 & 65,1 & 5,7 & 0,54 \\
\hline 435 & 265 & 39,6 & 12,1 & 1,1 & 0,0 & 2,7 & 8,7 & 34,3 & 0,0 & 1,5 & 53,5 & 7,1 & 0,87 \\
\hline 480 & 276 & 47,5 & 11,9 & 0,4 & 0,4 & 3,6 & 9,4 & 26,1 & 0,7 & 0,0 & 64,5 & 12,2 & 0,55 \\
\hline 703 & 435 & 32,2 & 16,8 & 1,4 & 0,7 & 3,7 & 14,0 & 30,1 & 0,2 & 0,9 & 51,7 & 10,9 & 0,94 \\
\hline
\end{tabular}


Stentællings-

\begin{tabular}{|c|c|c|}
\hline 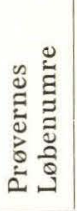 & 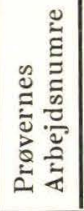 & Lokaliteter \\
\hline & & Moræne $\mathbf{B}_{2}$ (fortsat) \\
\hline 35 & 39 & Foroven i Bagvæggens Midte Vest for $171913 \ldots \ldots \ldots \ldots \ldots$ Parti VI \\
\hline 36 & 17 & $-\quad \quad-\quad$ Østende $\quad-\quad-\quad-\quad-\ldots \ldots \ldots \ldots \ldots \quad-$ \\
\hline 37 & 12 & Over Tellinaleret, yderst i den østl. Sidevæg, Faldet Vest f. 131913 \\
\hline 38 & 35 & 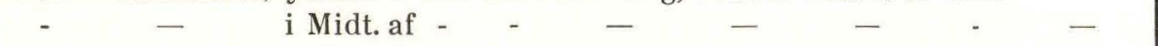 \\
\hline 39 & 36 & 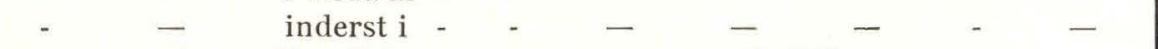 \\
\hline 40 & 14 & Yderst i den østlige Sidevæg, Faldet Vest for $131913 \ldots \ldots \ldots$. \\
\hline 41 & 32 & Midten af $-\quad-\quad-\quad-\quad-\quad-\quad-\quad-\ldots \ldots \ldots$ \\
\hline 42 & 30 & Inderst $\mathrm{i} \quad-\quad-\quad-\quad-\quad-\quad-\quad-\quad-\quad-\ldots \ldots \ldots-$ \\
\hline 43 & 33 & Morænen i Klinten Vest for Christiansminde Vejen $1912 \ldots \ldots \ldots$ Parti III \\
\hline 44 & 34 & $\begin{array}{lllllllll}- & - & - & - & - & - & - & 1914 \ldots \ldots & -\end{array}$ \\
\hline 45 & 13 & $-\ldots \ldots \ldots$ \\
\hline & & Moræne $\mathrm{C}_{1}$ \\
\hline 46 & 57 & Stejl Moræne Vest for $B_{2} 1912 \ldots \ldots \ldots \ldots \ldots \ldots \ldots \ldots \ldots$ Parti IX \\
\hline 47 & 59 & $-\quad-\quad-\quad-\quad-1913 \ldots \ldots \ldots \ldots \ldots \ldots \ldots \ldots \ldots \ldots \ldots \ldots \ldots \ldots \ldots$ \\
\hline 48 & 43 & $-\quad-\quad-\ldots \ldots \ldots \ldots \ldots \ldots \ldots \ldots \ldots \ldots-$ \\
\hline 49 & 56 & Inderst i den østlige Sidevæg i Faldet mell. 17 og 201913 Parti VII \\
\hline 50 & 55 & Lidt NØf.49 lavere nede $\quad-\quad\left[\begin{array}{lllllll}- & - & - & - & - & -\end{array}\right.$ \\
\hline 51 & 54 & 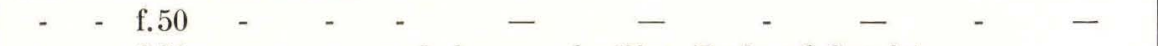 \\
\hline 52 & 53 & 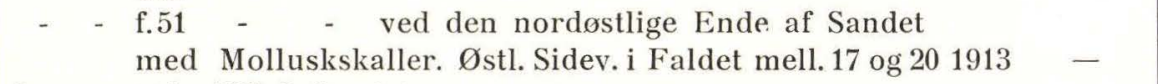 \\
\hline 53 & 52 & 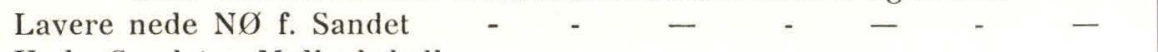 \\
\hline 54 & 51 & Under Sandet m. Molluskskaller - \\
\hline 55 & 50 & $\begin{array}{llllllllll}- & - & - & - & - \text { lav.n. }- & - & - & - & - & -\end{array}$ \\
\hline 56 & 47 & Bagvæggen i Faldet vest for $171913 \ldots \ldots \ldots \ldots \ldots \ldots \ldots$ Parti vI \\
\hline 57 & 48 & $-\quad-\quad-\quad-\quad-\quad-\ldots \ldots \ldots \ldots \ldots \ldots \ldots \ldots \ldots \ldots$ \\
\hline 58 & 49 & $-\quad-\quad-\quad-\quad-\quad-\quad \ldots \ldots \ldots \ldots \ldots \ldots \ldots$ \\
\hline 59 & 44 & Yderst, over B over Tellinaler Østl. Sidev. i Faldet Vest f. 131913 \\
\hline 60 & 45 & 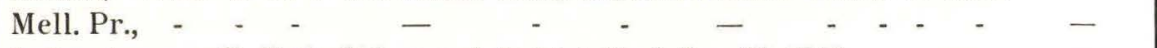 \\
\hline 61 & 46 & Inderst, over B Østl. Sidevæg i Faldet Vest for $131913 \ldots \ldots \ldots$ - \\
\hline 62 & 42 & 12 m under Vestenden af Gruslaget. Klinten V.f.Chrmindevejen 1914 Parti III \\
\hline 63 & 58 & $\begin{array}{lllllllllll}1,2- & - & - & - & - & - & - & - & - & - & -\end{array}$ \\
\hline 64 & 70 & $\begin{array}{l}\text { Moræne } C_{2} \\
\text { Nederste Prøve, regnet fra Strandbr., Faldet mell. } 17 \text { og } 20 \text { 1914. Parti VII }\end{array}$ \\
\hline 65 & 71 & 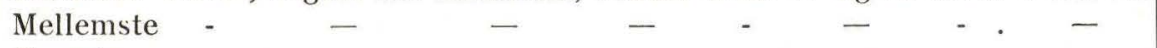 \\
\hline 66 & 72 & 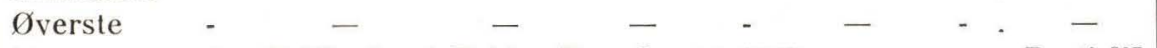 \\
\hline 67 & 68 & Morænen under Tellinaleret Faldet Vest for $171913 \ldots \ldots \ldots \ldots$ Parti VI \\
\hline
\end{tabular}


Tabel (fortsat).

\begin{tabular}{|c|c|c|c|c|c|c|c|c|c|c|c|c|c|}
\hline 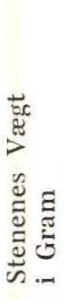 & 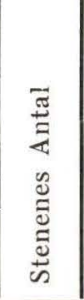 & 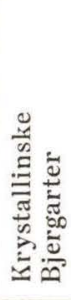 & 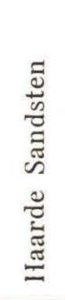 & 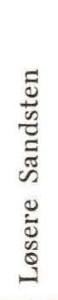 & 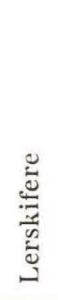 & 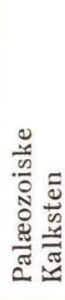 & 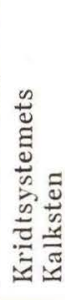 & $\underset{\Xi}{\vec{\Xi}}$ & 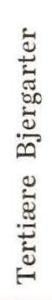 & 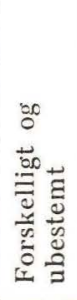 & 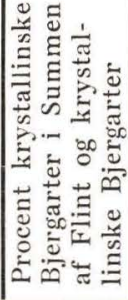 & 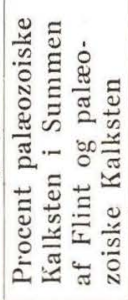 & 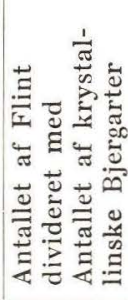 \\
\hline 051 & 635 & 36,7 & 8,7 & 1,3 & 0,3 & 2,0 & 16,1 & 33,7 & 0,9 & 0,3 & 52,1 & 5,7 & 0,92 \\
\hline 325 & $>752$ & 41,8 & 11,7 & 2,1 & 0,1 & 4,5 & 10,0 & 29,4 & 0,4 & 0,0 & 58,7 & 13,3 & 0,70 \\
\hline 715 & 421 & 38,7 & 7,4 & 2,1 & 0,2 & 3,1 & 13,8 & 32,3 & 2,1 & 0,3 & 54,5 & 8,7 & 0,83 \\
\hline 721 & $>304$ & 40,5 & 16,1 & 2,3 & 0,0 & 0,0 & 0,0 & 41,1 & 0,0 & 0,0 & 49,6 & 0,0 & 1,02 \\
\hline 407 & 269 & 36,8 & 16,7 & 1,9 & 0,0 & 0,0 & 0,0 & 35,3 & 0,0 & 9,3 & 51,0 & 0,0 & 0,96 \\
\hline 890 & 528 & 37,7 & 6,6 & 3,4 & 0,4 & 1,9 & 15,2 & 33,1 & 0,9 & 0,8 & 53,2 & 5,4 & 0,88 \\
\hline 530 & 306 & 36,3 & 11,8 & 1,0 & 0,0 & 5,6 & 15,0 & 29,7 & 0,3 & 0,3 & 55,0 & 15,7 & 0,82 \\
\hline 817 & $>316$ & 42,4 & 11,1 & 1,6 & 0,0 & 3,5 & 8,2 & 33,2 & 0,0 & 0,0 & 56,1 & 9,5 & 0,78 \\
\hline 224 & 157 & 28,7 & 7,6 & 1.3 & 0,0 & 6,4 & 25,4 & 26,1 & 1,3 & 3,2 & 52,3 & 19,6 & 0,91 \\
\hline 420 & 219 & 35,1 & 10,5 & 3,2 & 0,5 & 5,5 & 10,0 & 31,1 & 3,6 & 0,5 & 53,1 & 15,0 & 0,88 \\
\hline 495 & 256 & 34,1 & 13,3 & 1,4 & 0,0 & 3,2 & 16,0 & 26,6 & 4,7 & 0,7 & 56,4 & 10,5 & 0,77 \\
\hline 408 & 244 & 48,0 & 15,2 & 2,9 & 0,8 & 3,7 & 5,7 & 22,9 & 0,8 & 0,0 & 67,6 & 13,8 & 0,48 \\
\hline 298 & 233 & 45,5 & 12,0 & 3,9 & 0,0 & 6,9 & 9,4 & 19,3 & 2,6 & 0,4 & 70,2 & 26,2 & 0,42 \\
\hline 405 & 322 & 48,1 & 10,6 & 2,5 & 0,0 & 5,3 & 9,0 & 23,6 & 0,6 & 0,3 & 67,1 & 18,3 & 0,49 \\
\hline 338 & 234 & 42,7 & 12,4 & 2,6 & 0,0 & 8,5 & 8,5 & 21,8 & 2,6 & 0,9 & 66,2 & 28,2 & 0,51 \\
\hline 335 & 192 & 38,6 & 7,8 & 2,6 & 1,0 & 15,6 & 10,4 & 19,3 & 3,7 & 1,0 & 66,6 & 44,8 & 0,50 \\
\hline 249 & 191 & 39,3 & 6,8 & 0,5 & 1,1 & 13,6 & 12,0 & 20,9 & 2,1 & 3,7 & 65,2 & 39,4 & 0,53 \\
\hline 280 & 178 & 36,0 & 13,5 & 3,9 & 0,0 & 19,7 & 6,7 & 18,0 & 2,2 & 0,0 & 66,6 & 52,2 & 0,50 \\
\hline 327 & 184 & 38,6 & 8,7 & 4,9 & 0,5 & 13,1 & 9,8 & 22,8 & 1,1 & 0,5 & 62,8 & 36,4 & 0,59 \\
\hline 200 & 140 & 41,4 & 8,6 & 1,4 & 1,4 & 12,9 & 10,0 & 20,0 & 0,7 & 3,6 & 67,4 & 39,1 & 0,48 \\
\hline 157 & 121 & 28,1 & 16,5 & 1,7 & 1,7 & 19,0 & 16,5 & 14,0 & 0,8 & 1,7 & 66,7 & 57,5 & 0,50 \\
\hline 375 & 175 & 40,0 & 12,6 & 1,1 & 0,6 & 13,6 & $\mathbf{1 0 , 9}$ & 20,6 & 0,0 & 0,6 & 66,0 & 40,0 & 0,51 \\
\hline 317 & 233 & 39,0 & 12,9 & 3,4 & 0,0 & 15,5 & 13,3 & 15,5 & 0,4 & 0,0 & 71,7 & 50,0 & 0,40 \\
\hline 571 & $>234$ & 38,5 & 12,4 & 3,4 & 0,4 & 15,8 & 10,7 & 17,1 & 1,7 & 0,0 & 69,2 & 48,1 & 0,44 \\
\hline 230 & 182 & 39,6 & 12,6 & 0,6 & 1,1 & 12,6 & 11,0 & 22,5 & 0,0 & 0,0 & 63,7 & 35,9 & 0,57 \\
\hline 258 & 183 & 35,5 & 11,5 & 1,1 & 0,5 & 19,1 & 12,6 & 16,9 & 2,2 & 0,6 & 67,7 & 53,0 & 0,48 \\
\hline 246 & 150 & 58,7 & 9,3 & 3,3 & 0,7 & 0,0 & 0,0 & 25,3 & 2,7 & 0,0 & 69,8 & 0,0 & 0,43 \\
\hline 540 & 327 & 37,6 & 11,9 & 2,8 & 0,0 & 6,1 & 14,0 & 20,5 & 1,2 & 5,9 & 64,7 & 23,0 & 0,54 \\
\hline 435 & 279 & 43,7 & 9,3 & 1,1 & 0,4 & 8,6 & 12,9 & 21,5 & 0,0 & 2,5 & 67,0 & 28,6 & 0,49 \\
\hline 184 & 157 & 31,2 & 9,6 & 0,6 & 0,0 & 7,0 & 21,0 & 29,3 & 0,0 & 1,3 & 51,6 & 19,3 & 0,94 \\
\hline 255 & 166 & 33,1 & 10,8 & 0,6 & 1,3 & 10,8 & 15,1 & 25,8 & 0,6 & 1,9 & 56,1 & 29,5 & 0,78 \\
\hline 237 & 174 & 32,8 & 7,5 & 1,7 & 0,6 & 5,2 & 22,9 & 27,6 & 1,7 & 0,0 & 54,3 & 15,8 & 0,84 \\
\hline 350 & 169 & 36,1 & 12,4 & 0,6 & 0,6 & 6,5 & 16,6 & 27,2 & 0,0 & 0,0 & 57,0 & 19,3 & 0,75 \\
\hline
\end{tabular}




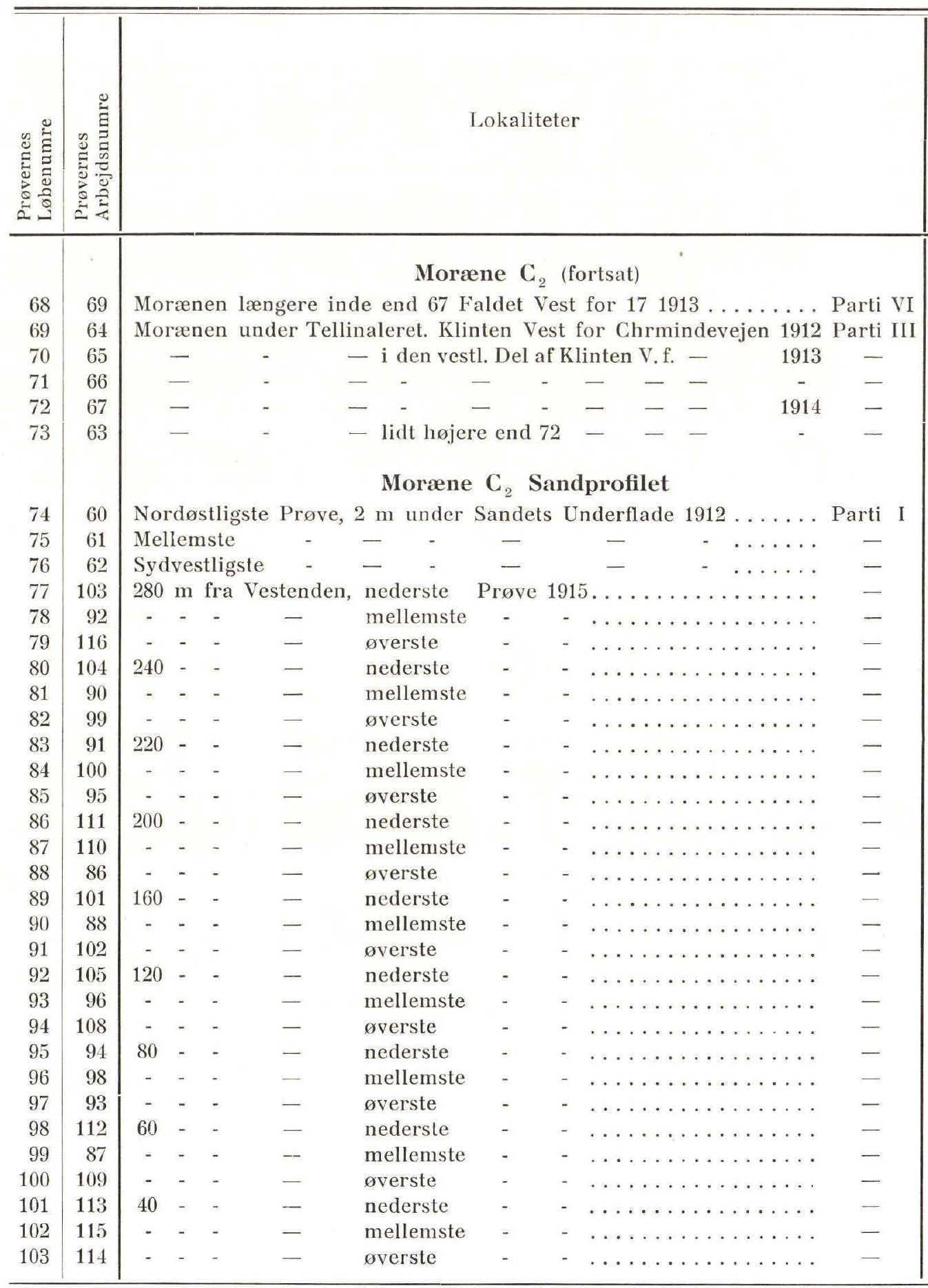


Tabel (fortsat).

\begin{tabular}{|c|c|c|c|c|c|c|c|c|c|c|c|c|c|}
\hline 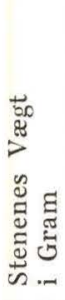 & 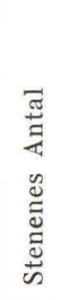 & 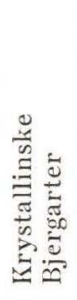 & 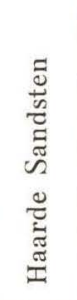 & 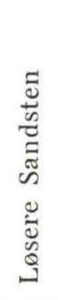 & 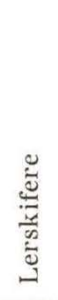 & 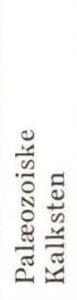 & 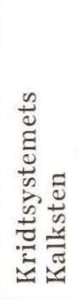 & $\underset{\Xi}{\vec{\Xi}}$ & 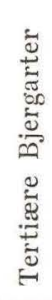 & 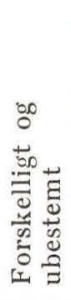 & 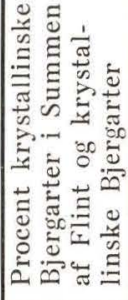 & 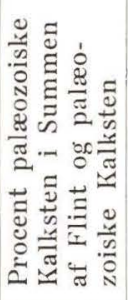 & 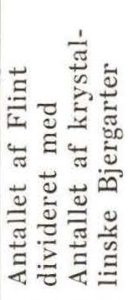 \\
\hline 157 & 156 & 34,0 & 12,2 & 2,6 & 0,0 & 7,0 & 16,0 & 26,9 & 0,0 & 1,3 & 55,8 & 20,8 & 0,79 \\
\hline 405 & 223 & 37,7 & 10,8 & 2,7 & 0,5 & 4,0 & 16,6 & 27,3 & 0,4 & 0,0 & 57,9 & 12,8 & 0,73 \\
\hline 450 & 263 & 45,6 & 10,7 & 2,3 & 0,7 & 3,4 & 5,3 & 31,2 & 0,8 & 0,0 & 59,4 & 9,9 & 0,68 \\
\hline 407 & 302 & 36,8 & 14,2 & 2,3 & 0,0 & 4,0 & 9,6 & 29,5 & 3,6 & 0,0 & 55,5 & 11,9 & 0,80 \\
\hline 342 & 200 & 41,5 & 18,5 & 3,5 & 0,0 & 0,0 & 0,0 & 30,0 & 6,5 & 0,0 & 58,0 & 0,0 & 0,72 \\
\hline 253 & 100 & 49,0 & 11,0 & 3,0 & 0,0 & 0,0 & 0,0 & 32,0 & 2,0 & 3,0 & 60,5 & 0,0 & 0,65 \\
\hline 470 & 218 & 32,6 & 11,0 & 1,8 & 0,5 & 7,3 & 14,2 & 32,1 & 0,0 & 0,5 & 50,4 & 18,6 & 0,98 \\
\hline 495 & 213 & 36,6 & 13,1 & 3,8 & 1,4 & 8,5 & 18,8 & 16,9 & 0,0 & 0,9 & 68,4 & 33,3 & 0,46 \\
\hline 207 & 185 & 29,7 & 10,8 & 4,9 & 1,1 & 17,8 & 14,6 & 20,0 & 0,0 & 1,1 & 59,8 & 47,1 & 0,67 \\
\hline 368 & 248 & 33,1 & 13,7 & 0,4 & 0,0 & 11,7 & 11,3 & 27,4 & 1,2 & 1,2 & 54,7 & 29,9 & 0,83 \\
\hline 393 & 248 & 35,9 & 12,1 & 2,0 & 0,4 & 14,5 & 10,1 & 24,6 & 0,4 & 0,0 & 59,3 & 37,2 & 0,69 \\
\hline 481 & 292 & 28,1 & 13,0 & 0,0 & 0,3 & 9,2 & 23,6 & 23,0 & 0,7 & 2,1 & 55,0 & 24,8 & 0,82 \\
\hline 230 & 206 & 34,4 & 18,9 & 1,5 & 0,5 & 11,2 & 9,7 & 19,4 & 4,4 & 0,0 & 64,0 & 36,5 & 0,56 \\
\hline 271 & 197 & 37,6 & 12,2 & 2,0 & 0,5 & 9,7 & 15,2 & 22,8 & 0,0 & 0,0 & 62,2 & 29,7 & 0,61 \\
\hline 194 & 197 & 31,0 & 13,2 & 2,0 & 0,5 & 10,1 & 15,2 & 22,4 & 2,0 & 3,6 & 58,1 & 31,3 & 0,72 \\
\hline 364 & 192 & 34,9 & 18,2 & 2,1 & 1,0 & 13,0 & 10,9 & 18,3 & 1,6 & 0,0 & 65,8 & 41,7 & 0,52 \\
\hline 282 & 207 & 39,1 & 10,2 & 3,4 & 0,0 & 13,0 & 15,0 & 16,4 & 1,9 & 1,0 & 70,5 & 44,3 & 0,42 \\
\hline 545 & 257 & 37,4 & 14,8 & 1,6 & 0,8 & 14,0 & 10,1 & 19,0 & 1,9 & 0,4 & 66,3 & 42,5 & 0,51 \\
\hline 375 & 261 & 36,8 & 16,8 & 0,8 & 0,8 & 9,2 & 15,3 & 15,3 & 1,5 & 3,5 & 70,6 & 37,5 & 0,42 \\
\hline 320 & 197 & 36,6 & 16,2 & 0,0 & 0,5 & 12,2 & 13,7 & 19,3 & 0,5 & 1,0 & 65,5 & 38,8 & 0,53 \\
\hline 394 & 209 & 40,7 & 12,0 & 3,3 & 2,4 & 2,0 & 10,3 & 17,2 & 0,0 & 1,9 & 70,3 & 41,0 & 0,42 \\
\hline 337 & 265 & 37,4 & 13,2 & 0,8 & 0,8 & 12,8 & 12,1 & 19,5 & 2,3 & 1,1 & 65,6 & 39,6 & 0,53 \\
\hline 474 & 185 & 34,1 & 14,0 & 1,1 & 0,5 & 13,0 & 10,3 & 26,0 & 0,5 & 0,5 & 56,8 & 33,4 & 0,76 \\
\hline 296 & 217 & 34,6 & 15,2 & 0,9 & 1,8 & 13,8 & 10,6 & 21,7 & 0,0 & 1,4 & 61,5 & 39,0 & 0,63 \\
\hline 328 & 177 & 27,7 & 11,3 & 1,1 & 0,0 & 10,7 & 18,7 & 28,8 & 1,1 & 0,6 & 49,0 & 27,2 & 1,04 \\
\hline 409 & 250 & 26,4 & 10,0 & 1,6 & 0,0 & 8,4 & 23,2 & 28,8 & 0,8 & 0,8 & 47,8 & 22,6 & 1,09 \\
\hline 447 & 240 & 23,4 & 10,4 & 1,2 & 0,8 & 9,6 & 30,0 & 23,8 & 0,8 & 0,0 & 49,6 & 38,8 & 1,02 \\
\hline 378 & 188 & 25,5 & 9,0 & 1,1 & 0,0 & 11,2 & 21,3 & 30,3 & 0,5 & 1,1 & 45,7 & 27,0 & 1,19 \\
\hline 373 & 247 & 17,0 & 12,5 & 0,8 & 1,6 & 8,1 & 26,4 & 31,6 & 0,0 & 2,0 & 35,0 & 20,4 & 1,86 \\
\hline 205 & 189 & 16,4 & 18,5 & 2,1 & 1,1 & 10,1 & 22,2 & 29,1 & 0,0 & 0,5 & 36,1 & 25,7 & 1,77 \\
\hline 235 & 171 & 20,4 & 15,8 & 0,6 & 1,8 & 9,9 & 24,0 & 25,7 & 0,6 & 1,2 & 44,4 & 27,9 & 1,26 \\
\hline 265 & 195 & 20,5 & 10,3 & 1,0 & 1,5 & 11,3 & 26,2 & 27,2 & 0,5 & 1,5 & 43,0 & 29,4 & 1,32 \\
\hline 325 & 242 & 24,4 & 10,7 & 0,8 & 0,0 & 8,7 & 25,6 & 29,8 & 0,0 & 0,0 & 45,1 & 22,6 & 1,22 \\
\hline 355 & 227 & 28,2 & 15,4 & 0,9 & 0,9 & 7,9 & 20,7 & 26,0 & 0,0 & 0,0 & 52,0 & 23,4 & 0,92 \\
\hline 315 & 244 & 23,8 & 13,1 & 0,4 & 0,4 & 11,1 & 26,2 & 23,0 & 1,2 & 0,8 & 50,9 & 31,8 & 0,97 \\
\hline 307 & 195 & 19,5 & 13,8 & 1,0 & 0,5 & 15,4 & 23,1 & 26,7 & 0,0 & 0,0 & 42,3 & 44,2 & 1,37 \\
\hline
\end{tabular}


Stentællings-

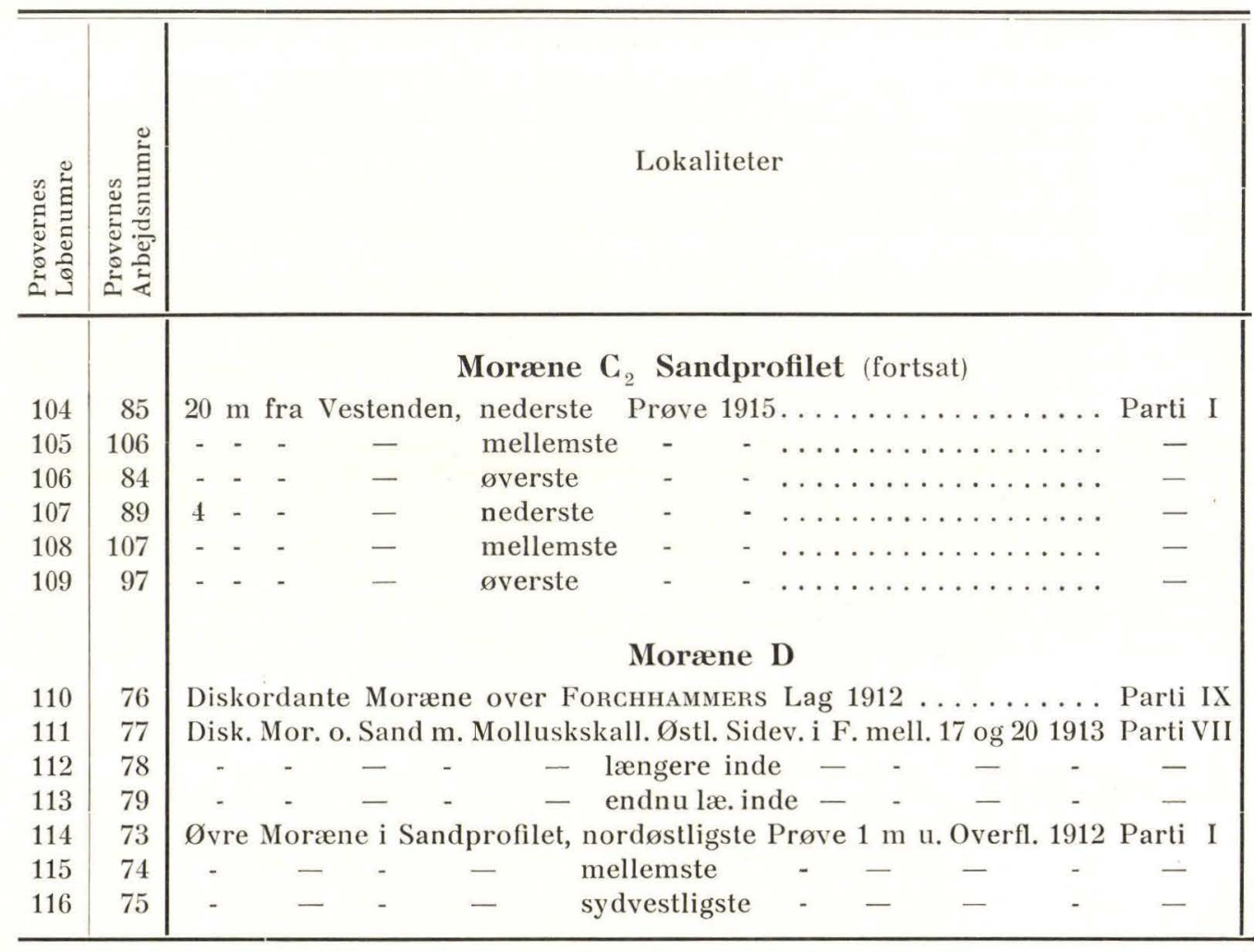


Tabel (fortsat).

\begin{tabular}{|c|c|c|c|c|c|c|c|c|c|c|c|c|c|}
\hline 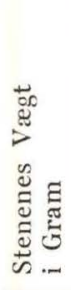 & 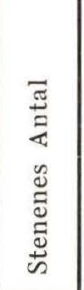 & 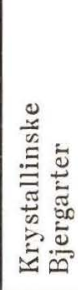 & 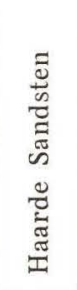 & 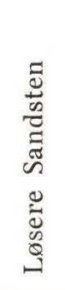 & 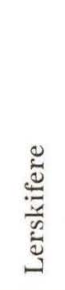 & 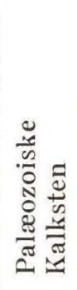 & 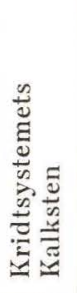 & $\stackrel{\vec{\Xi}}{\vec{I}}$ & 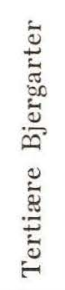 & 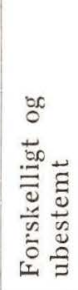 & 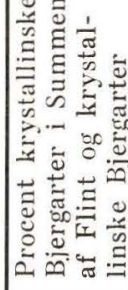 & 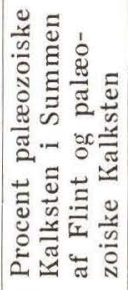 & 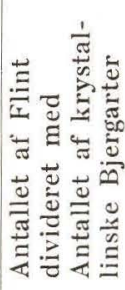 \\
\hline 325 & 248 & 20,6 & 8,1 & 2,4 & 1,2 & 13,3 & 26,6 & 27,0 & 0,4 & 0,4 & 43,2 & 33,0 & 1,31 \\
\hline 501 & 223 & 34,5 & 10,3 & 1,3 & 0,0 & 12,6 & 22,0 & 19,3 & 0,0 & 0,0 & 64,2 & 39,5 & 0,56 \\
\hline 333 & 235 & 18,3 & 9,3 & 1,3 & 0,0 & 8,1 & 32,8 & 29,4 & 0,0 & 0,8 & 38,4 & 21,6 & 1,60 \\
\hline 274 & 195 & 33,4 & 7,2 & 0,5 & 1,0 & 9,7 & 23,6 & 24,6 & 0,0 & 0,0 & 57,5 & 28,4 & 0,74 \\
\hline 301 & 220 & 23,6 & 9,5 & 0,5 & 0,0 & 12,3 & 26,4 & 26,8 & 0,9 & 0,0 & 46,8 & 31,4 & 1,13 \\
\hline 273 & 223 & 19,7 & 12,6 & 0,0 & 0,0 & 16,6 & 30,5 & 18,4 & 0,0 & $\cdot 2,2$ & 51,8 & 47,5 & 0,93 \\
\hline 369 & 138 & 43,5 & 8,0 & 2,9 & 0,0 & 0,0 & 0,0 & 45,6 & 0,0 & 0,0 & 48,8 & 0,0 & 1,05 \\
\hline 363 & $>172$ & 27,9 & 8,7 & 0,6 & 1,2 & 7,0 & 18,0 & 36,0 & 0,6 & 0,0 & 43,6 & 16,2 & 1,29 \\
\hline 178 & 156 & 27,6 & 9,6 & 1,3 & 0,0 & 5,8 & 17,9 & 32,0 & 5,8 & 0,0 & 46,2 & 15,3 & 1,16 \\
\hline 417 & 164 & \begin{tabular}{|l}
29,3 \\
\end{tabular} & 5,5 & 0,0 & 0,0 & 8,5 & 17,7 & 36,0 & 3,0 & 0,0 & 44,9 & 19,2 & 1,22 \\
\hline 690 & 313 & 30,4 & 7,7 & 0,9 & 0,3 & 7,3 & 18,2 & 33,9 & 1,3 & 0,0 & 47,3 & 17,8 & 1,11 \\
\hline 236 & 174 & 33,9 & 13,2 & 2,3 & 0,0 & 0,0 & 0,0 & 49,4 & 0,0 & 1,2 & 40,7 & 0,0 & 1,45 \\
\hline 319 & 220 & 37,3 & 9,0 & 2,3 & 0,9 & 0,0 & 0,0 & 47,7 & 1,4 & 1,4 & 43,9 & 0,0 & 1,28 \\
\hline
\end{tabular}




\section{Noter og Litteraturhenvisninger.}

1) Paa Generalstabens Maalebordsblad L. 5. Kirstinebjerg (maalt 1866, rettet i Marken 1885 og udgivet 1886) kaldes den vestligste Del af denne Klintstrækning for »Søensskjær»; det Sted, hvor Kysten forandrer Retning fra nordøstlig til østlig, benævnes »Røgle Klint", og det nordøstlige Fremspring, hvor KystRetningen bliver sydsydøstlig, kaldes »Stavrhoved ". Paa det nye Maalebordsblad 3312 Katrinebjerg (rettet 1906 og 1929 og udgivet 1929) er „Søensskjær flyttet til ud for Røgle Mose, og der er tilføjet enkelte Navne paa Ejendommene. Paa de af Søkortarkivet udgivne Søkort over Lillebelt genfindes de to sidste Navne paa de samme Steder; Stavrhoved skrives dog "Stavrshoved «. Ifølge Toldopsynsmand H. Jensen i Strib kaldes Klinten fra Røgle Mose til der, hvor Vejen gaar op til Christiansminde, for "Røgle Klint " og Dalen NNV for Christiansminde for "Runddal«; Klinten fra Christiansminde-Vejen til Kløften, hvori man først møder det Plastiske Ler, benævnes „Vornehoved (skal maaske være Vornedhoved); saa følger "Højskred (ikke at forveksle med Navnet Højskred paa en lille Ejendom lige Nord for Holmehus) til den store Kløft, der strækker sig op mod Røgle Nyhave, saa kommer "Nyskov" og derefter "Stavrhoved".

2) Kong Christian VI's egenhændige Breve til Greve Frederik DanneskjoldSamsøe 1734-45. Meddelte af J. Estrup. Danske Magazin, udgivet af Det kongelige danske Selskab for Fædrelandets Historie og Sprog. 5 Række, 5 Bd. Kjøbenhavn 1904, S. 172 :

Hiermit senden wir Ihm einen Extract von einem schreiben von graff Stollberg zu seiner nachricht zu, er wird daraus sehn, wasz selbiger von der in fühnen errtzhaltigen erde hält. Dasz de mercie kommen will, wen wir es befehlen; freuet uns sehr; Er wird Ihm mit nächster post schreiben, dass Er nur je eher je lieber kommen möge.

Friederichsberg d. 15 ten Dec. a. 1735.

Bilag:

Christian R.

Extract ausz graff Stollberg schreiben vom 11 ten 10 br. a. 1735 von Snaahe [Snoghøj].

Habe den strand bey Billeshagen [Billeshave] besehn und gefunden: Dass graff Wedell grund gehabt, attention auf besagte orth zu haben; Es befindet sich daselbst 1. eine schwartze Erde, in zimlicher quantitet, die dasz ansehen hat als die goldhaltende erde, so man den Bären dreck in den gold minen nennet, und giebet der major von Walkendorf [gift med Agathe Rodsteen Urne til Billeshave] für, dasz ein pfund einen viertel ducaten an gold halte, wovon die acurate probe in Teütschland machen will; indessen hohlen die leute in Fridericia desz nachts in böthen viel weg, so ein uhrmacher guht machen soll, worauf zu attendiren währe. 2 sein die Kneüste oder Schweffel Kisze zwar da, aber sehr eintzeln, welches, wan Sie reichhaltig (so die probe bey 
mir zeigen wird) bey kunftiger arbeit zu sammen gesparet werden können, bisz eine schmeltzwürdige quantité beysammen ist. 3. ist die terra Sigillata in grosser menge für handen und überausz schön zu Statuen thee guth und dergleichen zu gebrauchen. 4. ist ein blauer thon oder leim, worausz bötte und krüge, wie dasz Schwalbacher guht in Teütschland ist, zu grossen nutzen desz landes zu fabriciren stehet. Da nun auch ordinairer leim für handen ist, währe mein allerunterthänigster fürschlag Ew. Königl. Maj. erkaufen den platz nebst dem kleinen höltzgen von dem Major von Walkendorf und geben Ihn ohngefehr $4 / \mathrm{m}$ thaler dafür, und legten von anfang eine ziegel, topf und terra sigillata fabrique dahin, so sich wohl rentiren soll; ist aber die schwartze erde die rechte, so ist dieser orth ein grosser tresor.

Langere henne i Brevsamlingen findes som Bilag, skrevet med Kongens Haand, følgende Exctract ausz graff Stollberg sein schreiben vom 10 ten Febr. a. 1736 .

Die fühnsche Erde habe genau probiret, die schwartze hält nach beykommenden korn in $100 \widetilde{\pi} 1^{1 / 2}$ Ducaten gold, die schweffel Kisz $100 \pi \frac{\pi}{3}$ loth Silber, ist also die gold Erde zu arm, da Sie sich nicht ordinairement tractiren lässet, wan aber die schwefel Kisse aufgesamlet werden, dasz man eine quantitet beysammen hat, so wären Sie zu gebrauchen. Die rohte Erde ist ist sehr guth, und soll ehestens eine Statue erfolgen.

$\left.{ }^{3}\right)$ Pontoppidan E. 1763 . Den Danske Atlas. Kjøbenhavn. Tom. I, S. 453.

$\left.{ }^{4}\right)$ 1840. Oversigt over Vid. Selsk. Forh. S. 6 .

$\left.{ }^{5}\right)$ 1842. Beretn. om Vid. Selsk, hundredaarige Jubelfest den 25. Novbr. 1842, S. 21.

$\left.{ }^{6}\right)$ 1840. Oversigt over Resultaterne af hans i 1840 fortsatte geognostiske Undersøgelser af Danmark. Overs. Vidensk. Selskabs Forh., S. 4.

1842. Den skandinaviske Rullestensformations Forhold i Danmark. Förh. vid de Skandinav. Naturforsk. tredje Möte i Stockholm 1842, S. 85.

1842. Om Theorierne for Dannelsen af det øverste Jordlag og Flytningen af de løse Stenblokke deri. Dansk Ugeskrift. Række 2, Nr. 36 og 37, S. 158.

1843. Ueber Geschiebebildungen und Diluvial-Schrammen in Dänemark und einem Theile von Schweden. Poggendorff's Ann. d. Physik u. Chemie. Leipzig. Bd. 58, S. 617.

1858. Bidrag til Skildringen af Danmarks geographiske Forhold i deres Afhængighed af Landets indre geognostiske Bygning. Indbydelsesskrift til Kjøbenhavns Universitets Fest i Anledning af Hans Majestæt Kongens Fødselsdag den 6 te October 1858 , S. 30.

1865. Oversigt over Danmarks geognostiske Sammensætning. Förh. vid de Skandinav. Naturforsk. 9. Möte i Stockholm 1863, S. 11 (i Særtryk).

Forchнammer ansaa "Stauerhoved «-Forekomsten for saa vigtig, at han omtalte den i sine Forelæsninger for de Studerende. I et Kollegiehefte Danmarks Geognosie efter G. Forсhнамmer, Sommerhalvaaret 1851 - findes under Omtalen af Kattegatpartiet i Brunkulformationen: »Rullestensconglomerat findes paa mange Steder, men ikke større Sten end en Cubiktomme. De findes i Glimmerleer aldeles lagvis afsatte, men Lagene staa, paa det Sted vi især finde det, Stauerhoved ved Strib, lodrette, og har horizontale Gange (som før har staaet lodrette)."

I Forchнammers Manuskript-Protokol I, som opbevares i Mineralogisk Museums Arkiv, findes S. 138 følgende Optegnelse fra Rejsen 1840:

"I Nærheden af Friederits komme, som følger af tidligere Reiser, de tertiaire Steenarter til Overfladen. Ved Gaarden Striib paa Fyen seer man endnu ikke noget af disse Lag men naar man gaar derfra imod $\mathrm{N}$.[Ø] udfolder denne 
Dannelse sig i sin hele Mangfoldighed. De første tydelige Lag findes i Provsegaards Banke. Regelmæssige schichtede Sandlag af $1-2$ Fods Mrgtighed afvexlende med smaa Gruslag især Flint fra $2-4$ Tommer. Da Stranden løber her i Strygningsretningen ser det ud som om de ere horizontale men de falde $30^{\circ}$ imod N (Compass). Disse Lag ere bedækkede af guult Leer, uschichtet og med Rullestene. Bakken er omtrent 100 Fod høj og her findes ved Foden Blaaleer med overordentlig mange Flint. Dette Blaamergellag stiger, naar man gaar imod $\mathrm{N}$ og man kjender det meget let ved den Række af Kilder og Forekomster af Tussilago Farfare som ledsager disses Løb, og Adskillelseslinien imellem Sand og Leer. Blaaleerlagets Stene ere her Smaae Stene.

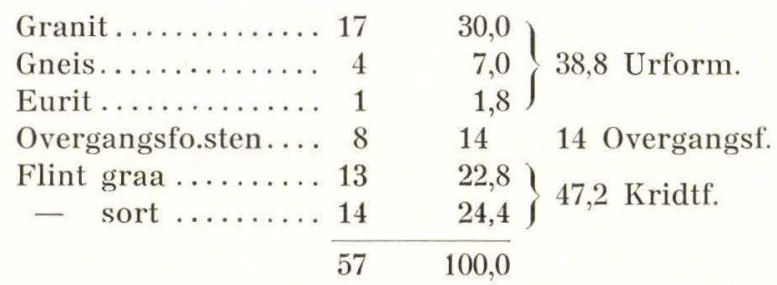

Længere imod NO ved Staverhoved kommer en Masse af bruunt Leer frem under dette blaa Leer. Det indeholder ingen Rullestene men heller ingen Septarier. Ved at forfølge Stranden endnu et lille Stykke, blive Forholdene meget tydelige. Brunkulformationen med Moleer og Alunjord træder pludselig frem.

Steenforholdene i Konglomeratlaget a b er følgende. Stenene mellemstore og smaae.

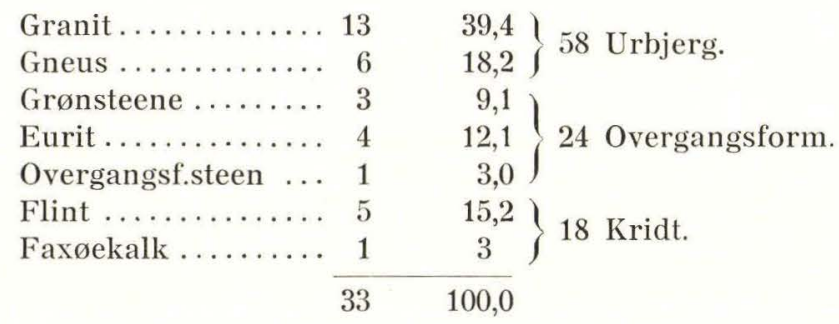

[Forchнамmer har først regnet Grønsteene og Eurit til Urbjerget, hvorved han fik 78,8 \% Urbjerg, 3,0\% Overgangsformationens Stenarter og 18,2\% Kridtformationens Stenarter, men derefter rettet det til det ovenstaaende.]

Desuden forekommer her en meget stor Mængde tertiaire Jernsteen som har foranlediget Dannelsen af Konglomeratet. Faxøekalken ligner den fra Faxøe i høj Grad. Den indeholder af Forsteninger Caryophyllæa faxøeensis, Brachiurus rugosum, Cypræa den nye som ligner C. bullata.

Noget længere hen træder Glimerleret meget mægtigt frem, det indeholder her ingen Rullestene, derpaa Lag med smaa Rullestene siden Rullesteens Lag som staa næsten lodrette $80-85^{\circ}$ imod $\varnothing$. Disse Rullesteenslag indeholde foruden Rullestenene en stor Mængde rulle Glimmerleerstykker saavel uden som med smaa indhyllede Rullestene. Lagene ere gennemskaarne af Gange som en Gang have været næsten lodrette og nu ved denne Omvæltning næsten ere blevne horizontale. De gaae igjennem Rullestenslaget og det urene Glimmerler [og] ere fyldte med Glimmerler.

Rullestenenes Forhold i Lagene 


\begin{tabular}{|c|c|c|c|}
\hline Granit............. & 14 & 46,7 & \multirow{4}{*}{63,3 Urform. } \\
\hline Gneis $\ldots \ldots \ldots \ldots \ldots$ & 1 & 3,3 & \\
\hline Grønsteen .......... & 2 & 6,7 & \\
\hline Eurit .............. & 1 & 3,3 & \\
\hline Quarts............. & 1 & 3,3 & \multirow{4}{*}{$\begin{array}{l}20 \text { Overgangs. } \\
16,7 \text { Kridt. }\end{array}$} \\
\hline Overgangsst......... & 6 & 20 & \\
\hline \multirow[t]{2}{*}{ Flint $\ldots \ldots \ldots \ldots \ldots$} & 5 & 16,7 & \\
\hline & & 100,0 & \\
\hline
\end{tabular}

Paa dette Konglomerat omtrent under samme $<$ og Faldretning følger et Lag af blaalig Glimmerleer og ligesom fine Sandschichter det er meget mægtigt. Derpaa følger Jernholdende Sandstene fulde af Forsteninger derpaa Glimmerleer og i dette Sækkeformige udfyldninger med Jernsten og Grønjord fulde af Forsteninger siden næsten sprødt Ler.

Paa Vejens Fortsættelse kommer man nu til mægtige Leerlag af brune, røde, grønne og gule Farver, undertiden Massivt undertiden skifrigt, med mange Koral-Septarier og enkelte Forsteninger i det skifrige Leer selv. Henimod Slutningen af Klinten forsvinde disse Lag, mægtige næsten horizontal schichtede Rullesteenslag komme frem og efter dem forsvinder Klinten.

Enkelte af Rullestenslagene ere Konglomerater dannede paa samme Maade som de tidligere omtalte. Indholdet er følgende:

\begin{tabular}{|c|c|c|}
\hline Granit........... 15 & 35,8 & \multirow{3}{*}{ 64,3 Urform. } \\
\hline Gneus $\ldots \ldots \ldots \ldots \ldots$ & 19,0 & \\
\hline Grønsten ........... & 7,1 & \\
\hline Eurit ............. & 2,4 & \\
\hline Overgangssten ...... 3 & 7,1 & 7,1 Overgangsf. \\
\hline Flint $\ldots \ldots \ldots \ldots \ldots, 10$ & 23,8 & 28.6 Kridtf. \\
\hline Grønsandskalk ..... 2 & $4,8\}$ & \\
\hline & 100,0 & \\
\hline
\end{tabular}

[ForсhнаммеR har først regnet Grønsten og Eurit til Overgangsformationen, men senere rettet det til ovenstaaende.]

Dette Rullestenslag viser false Stratification imod Ø $10-12^{\circ}$ altsaa Bølgeslaget fra denne Side."

Ved Optegnelserne findes nogle Skitser, hvoraf en bærer Aarstallet 1841, hvilket viser, at Forсннамmer atter besøgte Røgle Klint dette Aar (i Juli, paa Vejen fra Bogense til Middelfart). Om dette Besøg findes der iøvrigt intet i Manuskript-Protokolen. Skitsen fra 1841 er Originalen til Afbildningen i Poggendorff's Annaler. Originalen til Skitsen i Dansk Ugeskrift 1842 findes ikke i Forchнаmmers Manuskript-Protokol.

$\left.{ }^{7}\right)$ 1869. Om Jordbundens Dannelse i Danmark. Foredrag, holdt i Landmandsforsamlingens Møde den 8 de Juli. Særskilt Aftryk af »Tidsskrift for Landøkonomi «. Kjøbenhavn. S. 9-10 og 12 .

$\left.{ }^{8}\right)$ Da Johnstrups Beskrivelse af Røgle Klint har en ikke ringe Interesse baade som geologisk Tidsbillede og til Belysning af Forfatterens Personlighed, skal den anføres her. For at forstaa den maa man huske paa, at han benævner Tertiæret Brunkulformationen. Til denne henfører han Tellinaleret. Brk-Leer eller Brk $\mathrm{L}$ eller $\mathrm{Br} \mathrm{L}=$ Brunkuller. Gl Leer $=$ Glimmerler. $\mathrm{pl}=$ plastisk. tert $=$ tertiær. Forst $=$ Forsteninger. Kvartæret kaldtes den Gang Rullestensformationen; den deltes i Rullestensleret og Rullestenssandet. R-L eller R L = Rullestensler. G R L = gult Rullestensler, $\mathrm{Bl}$ R L $=$ blaat Rullestensler. R-S eller R S = Rullestenssand. 
Johnstrups Notater om Røgle Klint.

[S. 1] Strib. Baaringvig. Den $2 / 868$.

Bakkedragene indenfor Skrænterne ved Kysten Øst for Lavningen ved Bækken tæt ved Strib [Røgle Mose] gaae hovedsagelig i V- Ø, men er hverken meget høje eller meget sammenhængende.

Lavningen er adskilt fra Havet ved en meget bred og c. 6-10' Havstok af lutter Flyvesand med Linier af Tang indblandet.

Første store Klint. [Parti I]. En Skitse viser øverst »Leerbl. Sand over en mægtig Aflejring af vandrette Lag af Grus, Sand og »leerbl. S« over »R-L. R-L synes her at falde mod S, da der ingen Væld findes.

[S. 2] Denne første Række Klinter [Partierne I-III] gaar i N $70^{\circ} \varnothing$ og begynde før m paa Kortet, nemlig lige fra Lavningen med Bækken. Imellem $\mathrm{m} \mathrm{og}$ a (vide Pag. 4) ved Punktet $\mathrm{x}$ [paa S. 4 findes ikke disse Bogstaver] optræder Brk-Leer [Tellinaleret i Parti III] i afvexlende brune og sorte Lag med en Mængde underordnede Sandaarer, der snart tage til i Mængde, snart næsten aldeles forsvinde. Leret synes at være meget alunholdigt da $\mathrm{S} \mathrm{Fe} \mathrm{H}_{2}$ (basisk) at maaske Alun udvittrede paa Overfladen ligesom ogsaa $\mathrm{S}^{\mathrm{I}}$ fandtes af og til. Lejringsforholdene ere navnlig $\mathrm{i}$ det fjernere Parti noget vanskelige at tyde, da der intetsteds ses nogen blottet Flade. Alt er dækket af nedramlede Masser og selv hvor Faldretninger sees, er det dog uvist, om de tilhøre Lagene eller hidrøre fra Skred som c. Ved f Univalver i hele Lag $=$ Rullestenen i Museet.

[S. 3. Skitse af en Klint, vistnok Parti III. med følgende Paaskrifter] "Ø" "V."

"De øvre mere sænkede, men Rullestensform. er her meget tilbagetrængt." "brunt aaret plastisk Leer."

"fe

"Sort, med enkelte større Sandskorn"

"f"

$\gg \times 45^{\circ} \mathrm{VNV} . *$

" $8^{\circ}$ NO Sort og brunt aaret pl. Brk-Leer.

sc $150 \mathrm{Fd}$ Højde $60-70^{\prime}$."

[S. 4]. Imellem de Pag. 1 og 2-3 omtalte Klinter staar der en Overgang idet den mellemliggende her mægtigere R-L og Sandet er (enten) aldeles tilbagetrængt (eller snare sandet Leer) saa at guult R-L naar Overfladen. Det er ${ }^{1 / 2}$ Fjerdingvej udviklet ensformig Dannelse der er omtalt Pag. 1, men kun den høieste og mægtigste Bakke er aftegnet, de øvrige er noget lavere, men helt igennem R-L forneden, R-S foroven, omtrent af følgende Udseende.

[Her følger en Skitse af 4 Klinter. Den længst til Venstre er betegnet med Brk (Parti III), de 3 andre, Parti I og II, har øverst R S, derunder adskilt fra dette med en vandret Linie R L.]

[S. 5.] Dette brune og fede plastiske Leer [Tellinaleret i Parti III] adskiller sig fra det røde (blaa og grønne) at det er glimmerrigt selv om det indeholder nogle Gruskorn er det dog aldeles overfyldt med tydelige, hvide Glimmerblade. Det til Brk-Form hørende Sand synes at have den samme Egsk. og at mangle egentlige Rullesten.

[Paa S. 6 er tegnet et Profil, vistnok ogsaa Parti III, med Overskriften $\gg 36^{\circ} \mathrm{NNO}$

$32^{\circ} \mathrm{N} 45^{\circ} \varnothing$ Pynt $\mathrm{N} 80^{\circ} \varnothing$. betegnet paa Etiketten A."

Den viser til Venstre »Sort Brk L“, til Højre følgende Lag, som hælder til Venstre: "Sort Brk L

Sand 
Sort Brk L $32^{\circ} \mathrm{N} 45^{\circ} \varnothing$

Sand

Sort Brk L $36^{\circ}$ NNO. «]

[S. 7.] Omstaaende Profil taget umiddelbart som det viste sig i Skraaningen er vistnok et godt Bevis for, hvor forsigtig man maa vare ved Skred; thi der er næppe nogen Tvivl om, at det alene er gjentagne Gange nedskredne Masser, der giver denne Gjentagelse af Sort Brk L og Sand, der er yngre og tilligemed o o o o smaa Brokker af bruunt Brk Leer, der er udskyllet af Hovedlaget og indblandet i Sandlaget, [hvor]for at det, ligesom i den følgende Skrænt burde ligge ovenpaa Brk L, hvor endog lignende, om ikke Udskyllinger, saa selvstændige Lerlag (forsteningsførende) afvexler med Sandlaget, men altid øverst og ikke som her tæet ned ved Stranden, lavere end andre sorte Brk Leerlag.

[S. 8.] Hovedpartiet befinder sig i den Dal [hvori Vejen gaar op til Christiansminde], hvis to yderste mest fremragende Punkter, ligger $\mathrm{i}$ en Linie ab V $5^{\circ}$ $\mathrm{N}-\varnothing 5^{\circ} \mathrm{S}$. [Her følger en Kortskitse af Kysten. Den bestaar af en opadbøjet krum Linie, hvis venstre Endepunkt er betegnet med »a» og højre Endepunkt med sbء. Under dets opstigende venstre Del staar der $\gg$ C D E og under disse $c^{1 / 3}$ eller snarere $1 / 6$ af ac . Lidt til højre for det nederste Punkt danner den krumme Linie en lille Pukkel, som er betegnet med "c". Til højre for Skitsen staar der] c b er en kortere Strækning med højtliggende Væg altsaa R-L blaat. Resten er altsaa nedskredne røde, grønne og blaa pl. Leerarter, der danne store Skraaplaner op i Landet bevoxet med Buske, højere oppe er det dækket af R-L, uden at man naeer de foranst. Leerarter selv ved dybe Brøndgravninger Leret kan flyde under en Vinkel af $4-6^{\circ}$, medens R-L naar der er faa Sten deri danner mindst en Vinkel af $20^{\circ} \mathrm{og}$ det kun paa korte Strækninger.

[Paa S. 9 findes der til Venstre en skraa Skitse af nogle Partier af Sand, overlejret af $\mathrm{R}$-L«, med en Grænse mod dette, paa hvilken der 4 Steder staar m. Skraat under Skitsen staar der: "Hele dette Sandlag, der hviler paa Brk L helder $35-40^{\circ} \bmod$ NO . Til Højre for Skitsen staar der: »I Grænsefladen m er alle Steen og Sandkorn sammenkittede med et jernholdigt Bindemiddel.

Paa S. 10 findes en Skitse, over hvilken der staar: "Partiet B [væsentlig Parti V] c 100' høj». Den viser øverst "G. R. L.", under dette "Bl R L«, under dette til Højre Grus, betegnet med »o", og under dette et tyndt Lag, betegnet med »n«. Herunder findes der Lag, hældende til Venstre, af »Sort Glimmerleer med Forst. ", over hvilket der staar: " $22^{\circ} \bmod \mathrm{NO}$ ". Til Venstre for Midten af de skraa Lag staar der "p».]

[S. 11] $\mathrm{n}$ er et Lag af sandsynligvis Fe H (Bruunjernsten), der er steenhaardt; men er ogsaa det, der sammenkitter Conglomeratlaget (o) til en fuldstændig Stenmasse, hvori der findes forholdsvis mange tert. Stenarter.

Under $\mathrm{n}$ findes et tyndtskifret lysegult Leerlag (dannet af Brk Leer?) ved Omlægning i eller ved Udskylling af Leer. Det er conformt med Conglomeratlaget, men discordant mod de underliggende. Ved p afvexle Brk Leer (Forst.), maaske en Fortsættelse, men -...-.-Dannelse, med grovkornet glimmerløst Sand, og i de øvre Lag, der indeholde mange Spring findes eiendommelige conglomeratlignende Masser af Sand sammenkittet med Leer til smaa ovale Masser, men det hele meget løst og [S. 12] derfor vanskeligt at transportere.

Et meget vanskeligt Parti, de store Sten og maaske Alt, hvad der haves inde $\mathrm{i}$ den halvcirkelformede Fordybning er skredet ned imellem hverandre. Dog troer jeg nok at min Tydning er rigtig. 
Naar R-L er flydt ned mod Stranden, kan man være sikker paa, at det hviler paa Br-L, ellers staar det i lodrette Skrænter.

[S. 13 findes en Skitse »Partiet C [væsentlig Parti VI], en umiddelbar Fortsættelse af B «. Den viser "guult R-L « over "blaat R-L over et til Venstre hældende, tyndt $\gg$ Sandlaget, afbildet p. 9. Dette Sandlag er sandsynligvis en Fortsættelse af p Pag. 10, men paa Grund af Skreddene i B er Forbindelsen afbrudt «].

Under det skraa Sandlag staar der, antagelig omhandlende Aflejringen under Sandlaget: "Brunt og sort Glimmerler (det første meget plastisk), men Faldretningen er ret tydelig, maaske $20^{\circ} \mathrm{i}$ samme Retning som Sandlaget, men er ei til at bestemme nøjagtigt". Til Højre derfor staar der: "Nede ved Strandbredden er det forsteningsførende Leer udskredet, og Forsteningerne derfor knuste".

[S. 14.] Partiet D [væsentlig Parti VII] er omtrent ligestort med det Forrige, men er saa uordentligt, at det ikke er muligt at finde Rede deri. Det er saa godt som udelukkende R-L (blaat), her ligesom allevegne blot med Kridt- og Brk.-Form. Stenarter, i al Fald er disse ikke stort hyppigere her end de fleste andre Steder.

Det hviler vist paa Brk-Leer, at dømme efter den Uorden og Flydenhed der har været.

[S. 15 findes en Skitse "Partiet E (de hældende Lag) altid afbildet, som de sees fra Strandbredden «. Den forestiller aabenbart den vestligste Del af Partiet IX med de saakaldte Forchnammers Lag. Til Venstre staar der over næsten lodrette Lag: $>82^{\circ} \varnothing 15^{\circ} \mathrm{N}$. Enkelte tert. R. S. mest smaa og derunder: "Sorte Striber af sort Glimmerler indbl. R L." I Midten af Billedet staar der »aldeles utydeligt (større Afstand her imellem) « og derunder »130'\& aabenbart Profilets Længde. Til Højre ses to sammenhængende lodrette Folder, til Venstre for hvilke der staar ^R-L blandet med Kridt i er R S «. Til Højre for Folderne staar der $\times 80^{\circ}$ NOc. I Partiet til Højre for Folderne staar der R-L\&, og i Partiet over Folderne ligeledes "R-L". Foroven til Højre for Profilet staar der $\bowtie \times$ tyndskifr. Leer $\equiv$ Sand . $\times$ refererer til et fremhævet Lag, mærket med $x$, i den venstre Fold.

S. 16 findes en Skitse, over hvilken der staar: "Partiet E Fortsat c 30-40" . Den forestiller aabenbart den østlige Del af Partiet IX med Forchnammens Lag. Til Venstre staar der "R-L. Bruun Gl Leer. Hvid Leer (Prøve). Ocker med gr Tuf. br Gl Leer *. Til Venstre i de stejle Lag staar der: $₫ 52^{\circ} \varnothing 10^{\circ} \mathrm{N}$ ", og omtrent i Midten $₫ 60^{\circ}$ «. Til Højre i Skitsen, i det af Forchhammers Lag, som er længst til Venstre, og som er mærket $\times$, staar der $\$ 72^{\circ} \emptyset$ \&. Længere til Højre kommer der et Lag, mærket 2, endnu længere til Højre et Lag, mærket 1, hvorpaa der staar $\$ 80^{\circ} \varnothing$ ø, og aller længst til Højre et Lag mærket q. Over de stejle Lag staar der tre Steder r.]

[S. 17] q er sandede Lag, der indeholde, ja ere næsten fyldte med Brokker af sortebrunt Glimmerleer, der er knust, da det ei kunde taale at rulles. Det øvrige Parti ligner det aldeles.

$x)$ er lutter tynde Blade af skifrigt plastisk Leer.

Brk Leret til Venstre er det umuligt at finde Rede i, da det meste af Laget er nedskredet.

At der tilvenstre for $\mathrm{E}$ har været $\mathrm{R}-\mathrm{L}$ vidne de mange store Blokke, der ligge ud derfor paa Strandbredden, nu er der kun lidt tilbage. da umiddelbart til venstre viser sig et stort Parti Skrideleer, som maa findes her i stor Mængde, saa at det endog hviler ovenpaa de heldende Sandlag, ja flyder ud 
over dem ved r-r, idet det kommer fra bagved liggende Høj [S. 18] der hvortil det maaske er presset op, eller Sand og Leer presset ned i det.

I det næste Parti, hvis yderste Pynter ligger i en Linie $\varnothing 15^{\circ} \mathrm{S}$ bestaar den første Halvdel af R-L, den næste af plastiske røde og grønblaa Leerarter med indleirede Knolde (- Flinten) der bestaar af den Masse, som saa ofte findes som gule ofte lidt porøse (Forsteninger?) og lette Masser. Disse Leerarter danne først et stort Udfald, men naae længst mod $\varnothing$ den største Høide (Stouerhoved maaske snarere her) hvor de findes i den mest for- [S. 19] virret Leiring, dreiede, dog mest næsten lodrette $70^{\circ} \bmod$ SO, men det er meget tvivlsomt, om disse Heldninger, der forresten er temmelig constant paa en større Strækning, skyldes R-F Indvirkning, Skred eller anden Aarsag.

[Paa de følgende 4 Sider findes der en ikke synderlig udarbejdet Skitse af hele Røgle Klint, som dog har Interesse ved at angive Beliggenheden af Johnstrups Lokaliteter A, B, C, D og E.]

Den 3. August rejste Johnstrup videre til Fredericia.

$\left.{ }^{9}\right)$ Lundings Dagbog: „D. G. U. 1890. III. N. Chr. Lunding《 S. 40. Opbevares i Danmarks Geologiske Undersøgelses Arkiv.

$\left.{ }^{10}\right)$ Østrup, E. 1900. Diatoméer fra Tellina calcaria Leret i Røgle Klint. Medd. Dansk Geol. Foren. Bd. 1, Nr. 6, S. 21-22.

$\left.{ }^{11}\right)$ Munthe, Henr. 1899. En prioritetsfråga i ny belysning. Geol. Fören. i Stockholm. Förhandl. Bd. 21, H. 6, N:o 195, S. 620.

${ }^{12}$ 1893. Bull. Geol. Inst. of Upsala, N:o 2, Vol. I, Anm 2. S. 13.

$\left.{ }^{13}\right)$ Munthe, Henr. 1897. Studien über ältere Quartärablagerungen im südbaltischen Gebiete. Bull. Geol. Inst. of Upsala, N:o 5, Vol. III, 1896. S. 86.

$\left.{ }^{14}\right)$ Doktordisputats. Kjøbenhavn 1895. Trykt hos Nielsen \& Lydiche. Forfatteren gjorde Oplaget saa stort, at han kunde forære en Del af det til Dansk Geologisk Forening, saa at denne kunde udsende det med forandret Titelblad som »Meddelelser fra Dansk Geologisk Forening. Nr. 2. 1895 til sine Medlemmer, idet Foreningen den Gang ikke havde tilstrækkelige Midler til at udgive et Tidsskrift.

${ }^{15}$ ) Munthe, Henr. 1896. Till frågan om foraminiferfaunan i sydbaltiska kvartärlager. Geol. Fören. i Stockholm. Förh. Bd. 18, H. 4, N:o 172, S. 240, Anm. 3 .

${ }^{16)}$ Madsen, Victor. 1896. Nogle bemærkninger i anledning af H. Munthe: sTill frågan om foraminiferfaunan i sydbaltiska kvartärlager». Geol. Fören. i Stockholm. Förh. Bd. 18, H. 6, N:o 174, S. 550.

$\left.{ }^{17}\right)$ Munthe, Henr. 1897. Svar till V. Madsen. Geol. Fören. i Stockholm. Förh. Bd. 19, H. 2, N:o 177, S. 115.

${ }^{18)}$ 1897. Bull. Geol. Inst. Upsala. Vol. III, 1896-97, S. 83-86.

$\left.{ }^{19}\right)$ 1899. Medd. Dansk Geol. Foren. Bd. 1, Nr. 5, S. 7.

${ }^{20}$ ) Munthe, H. 1897. Studien über ältere Quartärablagerungen im südbaltischen Gebiete. Bull. Geol. Inst. Upsala. N:o 5, Vol. 3, 1896, S. 83.

${ }^{21}$ ) Munthe, Henr. 1899. En prioritetsfråga i ny belysning. Geol. Fören. i Stockholm. Förh. Bd. 21, H. 6, N:o 195, S. 619.

${ }^{22}$ ) Madsen, Victor. 1900. Yderligere bemærkninger om Røgle Klint. Geol. Fören. i Stockholm. Förh. Bd. 22, H. 2, N:o 198, S. 143.

${ }^{23}$ ) Munthe, Henr. 1900. Røgleklintprofilerne än en gång. Geol. Fören. i Stockholm. Förh. Bd. 22, H. 3, N:o 199, S. 207.

$\left.{ }^{24}\right)$ 1915. Medd. Dansk Geol. Foren. Bd. 4, H. 4, S. 433.

${ }^{25}$ ) Jessen, A. 1916. Om Dislokationerne i Lønstrup Klint. En foreløbig Meddelelse. D. G. U. Række IV, Bd. 1, Nr. 4, S. 28. 
$\left.{ }^{26}\right)$ Gripp, KarL. 1929. Glaciologische und geologische Ergebnisse der Hamburgischen Spitzbergen-Expedition 1927. Abh. d. Naturwissenschaftl. Vereins zu Hamburg. Bd. XXII, Heft 2-4. Hamburg. S. 177-180, 194, 207, 232, 245.

${ }^{27}$ ) Jessen, Axel. 1931. Lønstrup Klint. D. G. U. Række II, Nr. 49, S. 103.

${ }^{28}$ EBert, A. 1932. Magnetische Messungen im südwestlichen Dänemark. D. G. U. Række II, Nr. 53, S. 47.

${ }^{29}$ ) 1915. Medd. Dansk Geol. Foren. Bd. 4, H. 4, S. 433.

${ }^{30}$ ) 1928. Medd. Dansk Geol. Foren. Bd. 7, H. 3, S. 245.

${ }^{31}$ ) Harder, Poul. 1922. Om Grænsen mellem Saltholmskalk og Lellinge Grønsand og nogle Bemærkninger om Inddelingen af Danmarks ældre Tertiær. D. G. U. Række II, Nr. 38, S. 69.

${ }^{32}$ ) Nordmann, V. 1912. Fra Nordre Strømfjord og Gieseckes Sø. Det grønlandske Selskabs Aarsskrift. København.

Nordmann, V. 1921. Oversigt over naturvidenskabelige Undersøgelser i Grønland. "Naturens Verden«. 5. Aarg. København.

${ }^{33}$ ) Madsen, Victor. 1895. Istidens Foraminiferer i Danmark og Holsten. Medd. Dansk Geol. Foren. Bd. 1, Nr. 2, S. 105.

$\left.{ }^{34}\right)$ Østrup, E. 1900. Diatoméer fra Tellina calcaria Leret i Røgle Klint. Medd. Dansk Geol. Foren. Bd. 1, Nr. 6, S. 21.

${ }^{35}$ ) Munthe, H. 1897. Studien über ältere Quartärablagerungen im südbaltischen Gebiete. Bull. Geol. Inst. Upsala. N:o 5, Vol. 3, 1896, S. 85.

${ }^{36}$ ) Madsen, Victor. 1895. Istidens Foraminiferer i Danmark og Holsten. Medd. Dansk Geol. Foren. Bd. 1, Nr. 2, S. 169.

$\left.{ }^{37}\right)$ Harder, Poul. 1913. De oligocæne Lag i Jernbanegennemskæringen ved Aarhus Station. D. G. U. Række II, Nr. 22, S. 21.

${ }^{38}$ ) Ussing, N. V. og Madsen, Victor. 1897. Beskrivelse til Geologisk Kort over Danmark (i Maalestok 1:100000). Kortbladet Hindsholm. D. G. U. Række II, Nr. 2, S. 23.

39) Madsen, Victor m. fl. 1928. Oversigt over Danmarks Geologi. D. G. U. Række V, Nr. 4, S. 70, 84, 93, 107 og 110.

$\left.{ }^{40}\right)$ Den paa S. 11 nævnte Art Tellina baltica er ikke genfunden, hverken i det gamle af Dr. C. G. Joh. Peterensen bearbejdede Materiale, som opbevares i D. G. U.'s Samlinger, eller i det nye, i 1913 og senere indsamlede. 


\section{Résumé.}

Le Quaternaire de la falaise de Rögle au Petit-Belt. 


\title{
Introduction.
}

\author{
Indledning.
}

Lorsque de Strib on longe la côte de Lillebelt (Petit-Belt) vers l'est, on arrive, après avoir passé Rögle Mose, à une rangée de falaises qui suit la côte de la petite péninsule qui forme la partie le plus au nord-ouest de Fyn (Fionie). Ces falaises s'étendent à l'intérieur de Baaring Vig jusqu'à Fedet près de Möllemade. A plusieurs places elles sont si nettes et propres, que leur architecture se laisse explorer à pas mal d'endroits. Sur la première étendue, d'une longueur d'un peu plus de $2 \mathrm{~km}$, elles sont entièrement formées de dépôts quaternaires. Ensuite elles sont, pour la plupart, d'Argile plastique éocène, vulgairement nommée Argile du Petit-Belt.

Dans ce travail on ne traitera que de la première étendue des falaises, c.-a-d: celle qui part de Rögle Mose jusqu'au gisement le plus à l'ouest de l'Argile plastique, dans le dénommé «ravin d'Argile micacée». L'étendue de cette falaise est appelée dans l'ouvrage présent, «Rögle Klint» (la falaise de Rögle).

Pour faciliter la description et la compréhension de l'architecture de la falaise, nous l'avons partagée en 9 parties, marquées de I à IX. Partie I a une longueur de $375 \mathrm{~m}$ et comprend la partie la plus à l'ouest de la falaise, nommée «le profil de sable». Partie II a $850 \mathrm{~m}$ de longueur; elle forme la partie suivante de la falaise qui est entièrement couverte de végétation et aucunement dérangée. Partie III a une longueur de $170 \mathrm{~m}$; à cet endroit commencent les dérangements dans les dépôts de la falaise. Partie IV a $70 \mathrm{~m}$ de longueur et atteint l'endroit le plus bas de la vallée qui va jusqu'à la ferme Chistiansminde. Partie $V$ a une longueur de $190 \mathrm{~m}$ et atteint une saillie peu prononcée de la falaise, que nous avons appelée no. 11. Partie VI a $120 \mathrm{~m}$ de longueur; la falaise, à cet endroit, forme 2 descentes et 2 saillies en forme de nez, appelées no. 13 et no. 17 . Partie VII a $65 \mathrm{~m}$ de longueur; la falaise, ici, forme une descente limitée par 2 saillies en forme de nez, à savoir: no. 17 et no. 20. Partie VIII a $60 \mathrm{~m}$ de longueur et atteint jusqu'à la saillie en forme de nez no. 21 . On rencontre dans cette partie un ravin broussailleux dans lequel se trouve un important éboulement qui s'en va jusque dans le jardin de la ferme Sölyst. Partie IX a une longueur de $130 \mathrm{~m}$ et atteint jusqu'à $2040 \mathrm{~m}$ depuis le point final ouest de la falaise, jusqu'au dénommé «ravin d'Argile micacée» où le tertiaire commence. Les couches de cette partie se tiennent dans une position presque verticale.

Les reproductions du livre ne portant aucune indication, sont d'après les photographies de Victor MadSEN.

Lorsqu'on désire visiter la falaise de Rögle, on peut prendre un autocar de Middelfart à Strib et de là poursuivre sa route à pied le long de la côte 
en passant par le cordon littoral, situé près du marais de Rögle Mose, jusqu'à l'extrême pointe ouest de la falaise, où se trouve «le profil de sable», puis continuer sa route le long de la falaise. Mais on peut aussi, au lieu de longer instantanément la falaise, suivre la route à partir du marais de Rögle Mose, en passant devant les fermes Provsteskovlund, Söborg et Marielyst et jusqu'aux villas situées sur la falaise à l'est de Sölyst, où un petit sentier vous permet de descendre jusque sur la côte en passant par-dessus l'Argile plastique, se trouvant un peu à l'est du «ravin d'Argile micacée». Une fois sur la côte on n'a plus qu'à longer la falaise pour retourner à Strib. A l'extrême pointe ouest de la falaise de Rögle, se trouve un petit café nommé «Klinten», d'où la vue est très belle et où l'on peut se faire servir des rafraichissements.

Une carte des environs de la falaise de Rögle se trouve page 6 .

\section{Le développement \\ de la connaissance de la falaise de Rögle.}

Udviklingen af Kendskabet til Rogle Klint.

Le premier géoloque qui a entrepris les recherches de la falaise de Rögle, est Forchнammer, qui a travaillé ici en 1840 et 1841. A cette époque il mettait encore notre tertiaire au compte de «la formation des pierres roulées», qu'il partageait comme suit: 1) la formation d'ambre et lignite, 2) l'argile à pierres roulées, 3) le sable à pierres roulées. Il considérait la formation d'ambre et lignite, comme étant le Pliocène inférieur, l'argile à pierres roulées comme le Pliocène supérieur, et le sable à pierres roulées, comme s'étendant «profondément dans la période actuelle». Du fait que Forchhammer trouva, dans la falaise de Rögle, aussi bien de l'Argile plastique que de l'Argile micacée avec des fossiles tertiaires, et étant donné que l'argile à Tellina, dans laquelle il ne trouva pas de coquilles, ressemble beaucoup à l'Argile micacée et fut jugée par lui comme étant cette dernière, étant aussi donné que les couches de sable contiennent du mica et ressemblent souvent au Sable micacé tertiaire, il est assez naturel qu'il considéra les masses principales des dépôts dans la falaise de Rögle, comme appartenant à la formation d'ambre et lignite. Les fortes perturbations dans partie IX était ce qui l'intérressait le plus. Elles sont très souvent mentionnées et dépeintes par lui dans ses publications au cours des années suivantes, où il décrit «la partie de Kattegat» dans la formation d'ambre et lignite (fig. 1, page 9). Il en parlait aussi aux étudiants dans ses cours de géologie.

Forchнамmer mourut en 1865. Son successeur comme professeur à l'Université de Copenhague, F. Johnstrup, visita, un jour en 1868, la falaise de Rögle, et prit un profil qu'il ne publia cependant jamais. Il parle de l'argile à Tellina dans son journal, comme «de l'Argile micacée noire et brune». En 1873 il trouva dans l'argile à Tellina, des coquilles qu'il étiqueta: «Coquilles brisées dans de l'argile ligniteuse éboulée entre Strib et Staverhoved». Il continuait donc à considérer l'argile à Tellina comme tertiaire. Une de ces coquilles fut déterminée par O. Мӧвск, comme Tellina calcarea?

En 1884, la falaise de Rögle fut visitée par K. J. V. Steenstrup. On voit, par les étiquettes qu'il a placées près des coquilles de Tellina et de 
Saxicava qu'il a ramassées dans «une argile micacée grise peu consistante, falaise de Rögle, Strib», qu'il avait parfaitement la certitude que l'argile à Tellina est quaternaire.

Lorsque les travaux commencés en 1889 dans la partie nord de Fyn (Fionie) par le Service Géologique de Danemark et sous la direction de N. V. Ussing eurent atteint les parages de Strib en 1890, son assistant, N. Chr. Lunding, prit un profil complet de la falaise, depuis Rögle Mose jusqu'à Stulterigaarden près de Baaring Vig, à l'échelle 1:1811. Ce travail fut accompli avec un tel soin, qu'il fut d'un grand aide pour nous, lors de nos recherches en 1913-14. Ce profil est déposé dans les archives du Service Géologique. Les coquilles collectionées dans l'argile à Tellina par Lunding, ont été déterminées par C. G. Johs. Petersen en 1891, comme appartenant à Tellina calcarea, Tellina baltica et Saxicava rugosa, «avec cette supposition que la formation n'est pas tertiaire». La même année, E. Östrup trouva dans l'argile à Tellina des éspèces de diatomées qui font présumer «une précipitation dans une mer froide».

Pendant un voyage en 1892, le suédois Henr. Munthe, géoloque de l'Etat, alla, à la demande de N. V. Ussing, voir la falaise de Rögle. Il trouva, à cette occasion, des fragments de coquilles de mollusques dans les couches de sable et de gravier se trouvant tout en bas dans «le profil de sable» de partie I, et il prit un profil de cette partie de la falaise, qu'il ne publia toutefois qu'en 1897.

Les travaux du Service Géologique de Danemark dans la partie nord de Fyn (Fionie), ne furent repris qu'en 1893 et, alors, sous la direction de Victor Madsen. Il entreprit aussi, pendant ces travaux, des recherches dans la falaise de Rögle, dont quelques-unes furent publiées en 1895 dans l'étude «Foraminifères de l'époque glaciaire au Danemark et à Holsten, et leur signification pour l'étude des dépôts de l'époque glaciaire». A la pointe nord-ouest de la falaise (no. 13, partie VI) se trouve, tout en bas, de l'argile à Tellina avec des coquilles de Saxicava rugosa et Tellina calcarea. Par-dessus ceci se trouve une couche de gravier avec un grand nombre de grosses pierres, qui est recouverte d'un mince banc d'argile morainique grise et de sable stratifié. Par-dessus ceci se trouve, comme couche la plus haute dans la pointe, de l'argile morainique jaune. Dans la partie sud-ouest du chemin conduisant à Christiansminde, partie III, on trouve, tout en bas, de l'argile morainique sableuse d'un ton bleu-noir. Par-dessus celle-ci se trouve l'argile à Tellina, mais seulement en une mince couche et sans coquilles, et qui se transforme peu à peu en sable jaunâtre. Ces couches sont recouvertes par la couche de gravier aux nombreuses grosses pierres, laquelle est elle-même recouverte de couches alternantes de gravier, de sable et de banes d'argile morainique. Le placement des dépôts est démontré par une esquisse de ces sections de la falaise, (dans parties III-VI). Etant donné que l'argile à Tellina qui se trouve dans la partie III située au sud-ouest repose sur de l'argile morainique, et comme il se trouve, dans les deux parties, de l'argile morainique tout en haut de la falaise, on en conclut que l'argile à Tellina a été «déposée au commencement ou bien à la fin d'une période interglaciaire». D'après les recherches faites en 1913-14, il se montra, entre temps, qu'entre l'argile à Tellina et l'argile morainique placée dessous dans partie III, se trouve une dislocation, et que l'argile à Tellina et les couches au-dessus d'elle ont chevauché l'argile morainique qui se trouve à présent en-des- 
sous et qui est plus jeune que l'argile à Tellina; c'est pourquoi la base de la conclusion que l'argile à Tellina est interglaciaire n'est pas juste. Pourtant, l'argile à Tellina est interglaciaire, en ceci que dans partie V, se trouve, sous cette argile à Tellina, une couche de sable glacio-fluviale, et dans partie IX, aussi l'argile morainique la plus ancienne.

Ensuite il est parlé des dépôts du «profil de sable» et de fragments de coquilles de mollusques quaternaires et tertiaires, trouvés pendant les recherches faites dans les couches de gravier. Des listes sont données concernant les mollusques et foraminifères trouvés dans les couches de gravier et dans l'argile à Tellina.

L'interprétation du «profil de sable» donna lieu parfois, dans les années suivantes, 1896-1900, à de fortes discussions entre Munthe et VICTOR Mansen, ceci dû à ce que Munthe se faisait le porte-parole pour déclarer que le sable dans «le profil de sable» — plus tard précisé pour son gravier de $2 \mathrm{~m}$ d'épaisseur se trouvant tout en bas - était marin et non comme Madsen l'affirmait, glacio-fluvial. Après deux exposés de Munthe et un de Madsen, Munthe publia enfin ses observations en 1897. Ensuite MADSEN fit une conférence «Sur la division du Quaternaire danois», au 15 me Congrès des naturalistes à Stockholm en 1898, dans laquelle, entre autre, il avança que le sable dans «le profil de sable» de la falaise de Rögle et à plusieurs autres endroits de Fyn (Fionie), pouvait être déterminée comme étant plus jeune que l'argile à Cyprina (argile eemienne), en ceci que ces couches de sable contiennent la faune de l'argile à Cyprina en lit secondaire. Il fut le premier géologue danois qui adopta 3 époques glaciaires au Danemark, et il classa l'argile à Tellina dans la première époque interglaciaire et la plaça en commun avec la partie supérieure de l'argile à Yoldia d'Esbjerg. La conférence amena un nouvel exposé de la part de Munthe, dans lequel il maintint sa déclaration, sans cependant produire de nouveaux arguments.

Pendant l'été de 1899, Madsen eut l'occasion de réviser «le profil de sable», ce qui lui permit de constater que les fragments de coquilles apparaissent même à $5 \mathrm{~cm}$ sous l'argile morainique située tout en haut, et il n'y avait ainsi aucune raison de croire que les $2 \mathrm{~m}$ tout en bas pussent être plus marins que les couches de sable et de gravier se trouvant au-dessus d'eux, et dont l'épaisseur est de $16 \mathrm{~m}$; chose pourtant qu'il avança dans un nouveau traité en 1900. Dans sa réponse à ce sujet, Munthe admet bien que les couches de sable et de gravier, par suite de l'avancement de la nappe de glace par endroits et à des degrés plus ou moins grands, peuvent avoir été remaniées en matières glacio-fluviales; mais il maintient cependant ses déclarations précédentes, lesquelles il développe plus avant, en affirmant que les couches de sable et de gravier sont une formation de la côte dans «la mer d'argile à Cyprina» (Cyprinaler-Havet). Que ceci ne soit pas juste, est pleinement constaté dans les recherches faites par les auteurs en 1913 - 14, qui ont démontré que la moraine inférieure dans «le profil de sable», est déposée pendant la dernière époque glaciaire et est donc plus jeune que l'argile à Cyprina. Le sable et le gravier, qui sont plus jeune que la moraine inférieure, sont par conséquent aussi plus jeune que l'argile à Cyprina et ne peuvent pas avoir eu de relations avec celle-ci.

Une réponse au dernier article de Munthe fut imprimée comme une «Lettre au géoloque de l'Etat, Dr, en philosophie H. Munthe, de Victor Madsen», datée du 24 Avril 1900; et c'est sur ce, que prit fin la longue discussion. 
En juin et septembre 1913, ainsi qu'en 1914, les auteurs entreprirent des recherches détaillées de la falaise de Rögle, dont les résultats sont publiés dans le présent ouvrage, après avoir été révisés en septembre 1915.

Le 11 janvier 1915, les auteurs firent des conférences dans la Société Géologique danoise, sur «la falaise de Rögle, à Strib», dans lesquelles les résultats des recherches furent mis en évidence. Ils donnèrent lieu, dans la Société, le 22 février 1915, à une discussion sur «la cause des dislocations dans nos falaises», qui fut ouverte par MADSEN, et dans laquelle il se déclara partisan de l'hypothèse que les dislocations sont tectoniques, bien que pendant la recherche de détails de la falaise de Ristinge, à Langeland - qu'il entreprit en 1913 — il fut arrivé à cette conclusion que ses dislocations étaient dues à une poussée de glace. On avait justement découvert, pendant les recherches de détails de la falaise de Rögle, que cette falaise n'est pas construite de la même manière que la falaise de Ristinge, en ceci que les séries de couches dans parties VII-IX, sont inclinées les unes vers les autres. Ceci fut cause que les auteurs crurent devoir abandonner l'hypothèse de la poussée de glace et comprendre les dislocations dans la falaise de Rögle, comme tectoniques, conception qui se reporta donc aussi sur nos autres falaises. Une visite à la falaise de Lönstrup à Vendsyssel, faite en compagnie d'Axel Jessex, en 1915, renforça les auteurs dans leur opinion, en ceci qu'ils eurent la ferme impression que les dislocations dans cette falaise ne pouvaient avoir la poussée de la glace pour cause. Cependant ils n'étaient pas encore certains de quelle manière les dislocations dans la falaise de Rögle devaient être expliquées, pour la bonne raison qu'il leur était difficile de comprendre le tectonique de la falaise dans tous ses détails, et non moindre, dans le cas général, d'arriver à isoler les phénomènes qui avec certitude sont dus à l'action de la nappe de glace, de ceux qui peuvent être tectoniques. Ceci eut pour cause que la publication du traité de la falaise de Rögle fut ajournée, dans l'espoir que par la suite la question serait éclaircie par des révisions répétées de la falaise.

Une nouvelle lumière fut projetée sur la question des dislocations, par les observations de GripP dans le Spitsberg en 1927. Il découvrit que plusieurs glaciers à cet endroit avaient poussé leurs avant-terres gelées devant soi, en des systèmes de remparts parallèles, atteignant des hauteurs de 30 à $60 \mathrm{~m}$. Devant le Holmström-glacier il observa 30 de ces sortes de remparts parallèles, s'étendant au-dessus d'un terrain en courbe, en une longueur de plusieurs kilomètres et une largeur d'un $\mathrm{km}$. Les profils que les fleuves d'eau de fonte avaient créés à travers ces remparts, montraient, d'une part de grands plis, et d'autre part des séries de couches en pente, avec des chevauchements de même nature que dans les falaises de Lönstrup et de Ristinge, et qui furent comparés par Gripp, avec les remparts de «Stauch moraine» de Spitsberg.

Ces observations amenèrent Axel Jessen et Victor Madsen, en ce qui concerne la falaise de Lønstrup et la falaise de Ristinge, à retourner de nouveau à l'hypothèse de «poussée de glace». Cette hypothèse, par contre, ne semblait toujours pas pouvoir s'approprier à la falaise de Rögle. Cette falaise offre justement cette condition spéciale que, vers l'est, elle se limite à un horst d'Argile plastique d'au moins $3 \mathrm{~km}$ de large, qui n'est recouvert que d'argile morainique de minime épaisseur. Cette Argile plastique est, en plus, soulevée si haut, que sa partie la plus basse, avec ses couches de cendre volcanique, apparait au milieu, au nord-ouest de Holmehus. Cette 
partie surélevée atteint sa plus importante hauteur - $71 \mathrm{~m}$ - à la station trigonométrique, un peu au sud de la ferme Katrinebjerg, pendant que la plus importante hauteur de la falaise (dans partie V) est de $37 \mathrm{~m}$, et la hauteur du terrain, à la ferme de Stutterigaarden, est de $38 \mathrm{~m}$.

Si l'on pense que les parties ouest de la falaise - celles-là qui ont une certaine ressemblance dans leur architecture avec les falaises de Lönstrup et de Ristinge - ont été disloquées par une poussée de glace, la nappe de glace doit donc, à en juger par l'inclinaison des dislocations, être venue à peu près du nord-est, et on sait — dans ce cas-ci — que la falaise s'est trouvée à l'abri de la glace par le horst d'Argile plastique de $3 \mathrm{~km}$ de largeur, cependant que ni la falaise de Lönstrup ni la falaise de Ristinge n’ont été abritées par des horsts.

Les auteurs se sont donc, pour expliquer l'architecture de la falaise de Rögle, raccrochés à une idée qu'ils avaient déjà eu avant, mais qu'ils n'avaient pas poussée jusqu'au bout, justement, que les dislocations ont été causées par le soulèvement du horst d'Argile plastique, directement à l'est de la falaise, dont les parties les plus à l'est se limitent au horst par des couches presque verticales, la plus vieille se trouvant le plus près du horst, et qui s'éloignent de celui-ci à mesure que leur âge diminue. Les conditions, ici, sont analogues aux conditions des horsts de sel de l'Allemagne du nord, qui sont, de la même manière, limités par des couches dont la position est presque verticale. Les dislocations dans la falaise de Rögle sont donc à considérer comme tectoniques, peut-être même comme te ctoni ques de sel. Le bloc de dépôts quaternaires, épais de $140 \mathrm{~m}$, dont la position est maintenant verticale et qui se trouve directement à l'ouest du horst, dut, lorsque le horst se souleva, se procurer de la place. Il fut alors si comprimé, que son argile à Tellina fut presque pressée hors de lui; il comprima de même l'étendue de falaise, longue de $675 \mathrm{~m}$ (parties VIII-III) à l'ouest du bloc et provoqua les deux chevauchements dans les parties VI et III, ainsi que les plissements dans partie V. - La falaise de Rögle prend, en tout cas, une position exceptionnelle parmi les falaises danoises disloquées.

Des recherches géophysiques détermineront si la situation élevée de l'Argile plastique est vraiment due à un horst de sel souterrain soulevé par pression. Il n'a été, à ce sujet et jusqu'à ce jour, entrepris qu'une seule détermination d'intensité verticale de force magnétique. Elle fut exécutée par A. Eвert le 9 octobre 1930, dans le bois de Katrinebjerg Skov, à Lat. $55^{\circ} 32,8^{\prime}$, Long. $9^{\circ} 50,0^{\prime}$ E. et donna le résultat $\div 18 \gamma$, ce qui démontre qu'il se trouve, ici, un maximum relatif local, en ceci que le mesurage le plus proche, à une distance de $2,5 \mathrm{~km}$ vers le sud à Lat. $55^{\circ} 31,4^{\prime}$, Long. $9^{\circ} 49,8^{\prime}$ E., donna $\div 62 \gamma$, et le plus proche suivant, à une distance de $2,6 \mathrm{~km}$ vers l'ouest à Lat. $55^{0} 32,7^{\prime}$, Long. $9^{0} 47,6^{\prime}$ E., donna $\div 42 \gamma$. Le mesurage magnétique démontre done aussi, qu'un horst existe à cet endroit. Cette force magnétique relativement grande est due probablement à des combinaisons de fer se trouvant dans l'Argile plastique située très haut, ainsi que dans ses couches de cendre volcanique. Il est impossible de conclure, d'après le résultat des mesures, si dans le horst, se trouve un horst de sel soulevé par pression ou non, et l'avenir seul sera à même de répondre à cette question.

Lorsqu'au cours des années, des changements furent survenus dans l'aspect de la falaise, ceci dû aux continuelles attaques de la mer ainsi 
qu'à de nouveaux éboulis, Nordmann et Sigurd Hansen entreprirent, en 1931, quelques fouilles supplémentaires dans parties IV et V et des mesurages dans partie IX, dont les résultats sont rajoutés dans le présent ouvrage.

\section{Les dépôts dans la falaise de Rögle.}

Aflejringerne $i$ Røgle Klint.

Nos vérifications de la falaise de Rögle nous ont démontré qu'elle est formée par les dépôts suivants:

10. Moraine $D$.

9. Couches glacio-fluviales $c$.

8. Moraine $C$.

7. Moraine $B$.

6. Couches glacio-fluviales $b$.

5. Argile à Tellina.

4. Couches glacio-fluviales $a$.

3. Moraine $A$.

2. Argile micacée et Sable micacé.

1. Argile plastique.

\section{Argile plastique.}

Plastisk Ler.

L'Argile plastique sur les côtes du Petit-Belt, au N-E de Fredericia et à l'est de Strib, a, de vieille date, été considéré comme le type par excellence de l'Argile plastique danoise. Elle est exceptionnellement grasse et ne contient presque pas de sable. A l'état humide elle s'éboule en un mouvement glissant. Sa couleur varie, par-dessus, du gris-brun au gris bleu et au rouge-brique par-dessous. Elle contient des concrétions de carbonate de calcaire et de sulfate de baryte. Elle appartient à l'Eocène. Nous avons jugé qu'une plus étroite vérification de ceci, doit être considérée comme en dehors du plan de cet ouvrage.

\section{Argile micacée et Sable micacé. Glimmerler og Glimmersand.}

Il ne se trouve dans la falaise de Rögle, à part l'Argile plastique, que de très insignifiants restes d'autres sortes de terres tertiaires, c.-a-d: d'une part, de l'Argile micacée glauconieuse, noire et pauvre, dont la base est transformée en une couche de concrétions brunâtres par des précipations de combinaisons de fer; d'autre part, de Sable micacée glauconieux noirbrun ou clair et plus ou moins verdâtre. Dans la couche de concrétions se trouvent des coquilles de mollusques brisées et en très mauvais état. L'âge de ces dépôts doit être considéré comme appartenant à l'Oligocène supérieur, et peut-être, en partie, à l'Oligocène inférieure.

\section{Moraine $A$.}

Moræne A.

Le dépôt le plus âgé dans la falaise de Rögle est la moraine $A$, provenant de la première époque glaciaire danoise. On ne la trouve qu'immé- 
diatement à l'est du «ravin d'Argile micacée» dans partie IX, où elle se tient verticalement. Elle est composée d'argile morainique bleu-noirâtre ou noir-brunâtre, dans laquelle peuvent se trouver de nombreux étalements de sable. On a trouvé, dans la moraine $A$, un porphyre rhomboïdal, un silex tacheté, et des pyrites. Le quotient de l'énumération des blocs est $0,36 \pm 0,044$.

\section{Couches glacio-fluviales $a$. Glaciofluviale $\operatorname{Lag}$ a.}

La plus vieille série de couches glacio-fluviales est formée de sable jaune et blanc, contenant du mica et, d'un ordre inférieur, d'argile grise sans pierres. La matière provient apparemment, principalement de terres tertiaires. Il se trouve, dans les couches, de nombreux morceaux de différentes sortes de terres roulées, appartenant au tertiaire, tantôt elles sont ligniteuses, tantôt elles ressemblent davantage à l'Argile micacée. Il s'y trouve aussi «des pierres roulées» d'argile morainique, ainsi que quelques pierres. C'est dans cette forme typique bien à elle, que la série de couches se présente en une position verticale et avec une épaisseur d'environ $20 \mathrm{~m}$ dans partie IX, directement à l'ouest de la moraine $A$. Dans parties IV, V et VII il y a un dépôt de sable quartzeux micacé blanc qui, par son contenu de minces couches d'argile, ainsi que parcequ'il s'y trouve des morceaux de lignite roulées et «des pierres roulées» d'Argile plastique, doit être considéré comme appartenant aux couches glacio-fluviales $a$.

\section{L’argile à Tellina. \\ Tellinaleret.}

L'argile à Tellina est une sorte d'argile sombre, micacée, et contenant des coquilles. Elle peut être passablement grasse, mais en général elle est plutôt maigre. Presque partout, dans son épaisseur, se trouvent des couches de sable, ou bien de minces couches alternantes d'argile et de sable. Les couches de sable augmentent en nombre dans sa partie supérieure et inférieure. L'argile à Tellina a certainement commencé par un dépôt de couches alternantes de sable et d'argile, les couches de sable ayant été les prédominantes, mais, peu à peu, le charriage de l'argile prit en proportion, de sorte que les couches d'argile sont à leur tour devenues les prédominantes. Les conditions d'arrivage doivent cependant avoir souvent et subitement changé de tactique, puisque des couches de sable brut et pur, sans transition, alternent avec des couches d'argile grasse. Vers la fin de l'époque de formation, le charriage du sable prit de nouveau en proportion. L'argile à Tellina est déposée dans notre première époque interglaciaire. Son épaisseur originelle peut être évaluée à au moins $15 \mathrm{~m}$.

La faune de l'argile à Tellina. Tellinalerets Fauna (par V. NorDManN). La faune qui est trouvée dans l'argile à Tellina, comprend 30 foraminifères et 4 espèces de lamellibranches marins: Modiolaria lavigata, Tellina calcarea, Saxicava arctica et Mya truncata. Ils sont tous d'espèces arctiques et ont une vaste extension géographique, et peuvent vivre sous des conditions de nature assez variées. La pauvreté de la faune de mollusques n'est pas due à ce que leurs espèces appartiennent à l'eau saumâtre, au contraire: ce sont des animaux d'eau salée, nettement pro- 
noncés, qui dans des conditions normales vivent mélangés à beaucoup d'autres espèces. La cause de cette pauvreté doit donc ici - comme dans certaines localités se trouvant dans l'intérieur des régions d'argile à Yoldia - être due à des conditions spéciales, et l'on approche davantage de la cause, en pensant à des conditions comme celles qui existent dans certains fiords groenlandais, comme par exemple: le Nordre Strömfiord, oû les fleuves d'eau de fonte provenant de la nappe de glace, charrient une incroyable quantité de vase jusque dans le fiord. Aux endroits où le charriage de vase est par trop excessif, les mollusques sont tout simplement étouffés, et seules de rares espèces peuvent tenir bon un court laps de temps, bien que le pourcentage du sel de l'eau soit largement élevé.

On est, d'après ceci, en qualité de considérer l'argile à Tellina comme étant déposée dans un fiord ou une baie contenant de l'eau froide et où l'eau de fonte provenant de la nappe de glace, située à peu de distance, a amené une très grande quantité de vase argileuse et une quantité inférieure de sable.

Les foraminifères sont reportés à la page 26 , et les diatomées à la page 27 .

\section{Couches glacio-fluviales $b$.} Glaciofluviale Lag b.

Cette série de couches atteint son plus grand et son plus beau développement dans la demi-partie orientale de partie IX, où elle se rencontre avec les couches glacio-fluviales $a$, desquelles elle est séparée en bas par des couches d'argile gris-bleu sans pierres, contenant des bribes de matière tertiaire noire, et tout en haut par un morceau d'argile à Tellina. Cette série est formée de couches alternantes de sable et d'argile, dont quelques unes contiennent des pierres disséminées. On y trouve aussi quelques couches de gravier dont les pierres peuvent atteindre la grosseur d'une tête d'enfant. Les couches de cette série - située tout en bas-contiennent des bribes de matière tertiaire, lesquelles manquent dans les couches tout en haut. L'épaisseur, dans partie IX, est d'environ $11 \mathrm{~m}$.

A l'ouest de partie VIII, la série est représentée par une couche de pierres roulées et cimentées, couleur rouille, et dont l'épaisseur est d'environ $0,7 \mathrm{~m}$. La plupart de ces pierres ont la grosseur d'une noix ou d'une pomme, mais beaucoup atteignent la grosseur d'une tête humaine et même davantage. En étroite parenté avec cette couche, se trouvent à plusieurs endroits, de minces couches de sable et d'argile.

\section{Moraine $B$. \\ Moræne $B$.}

Cette moraine, déposée pendant la seconde époque glaciaire danoise, atteint, tout comme les couches glacio-fluviales, sa plus grande épaisseur, environ $23 \mathrm{~m}$, dans partie IX. Elle est en majeure partie formée d'argile morainique sableuse maigre et au ton gris-brun. Dans sa partie inférieure $B_{1}$, se trouvent des bancs contenant une grande quantité d'Argile micacée, et on a trouvé in situ, du porphyre quartzifère rouge de la mer Baltique, ainsi que de la pyrite. Le quotient de l'énumération des blocs est $0,50 \pm 0,49$.

La partie supérieure $B_{2}$ peut avoir un ton gris-bleu et être encore plus grasse, et contenir, en outre, des couches et des parties de gravier, de 
sable et d'argile sans pierres. On a de même, dans $B_{2}$, trouvé du Larvikite, du porphyre quartzifère rouge et brun provenant de la mer Baltique, de l'aragonite et de la pyrite. Le quotient de l'énumération des blocs est $0,82 \pm 0,026$. A l'ouest de partie VIII, ne se trouve que la partie supérieure.

\section{Moraine $C$. \\ Moræne C.}

Cette argile morainique, qui est déposée pendant la troisième époque glaciaire danoise, a l'air, dans son état non désagrégé et sec, d'une argile morainique bleue et normale. Lorsqu'elle se trouve dans un état humide, sa couleur prend alors un ton noir tout spécial qui, probablement, doit provenir d'un certain contenu d'Argile micacée. Le caractère peut cependant varier. Il en est ainsi dans la descente orientale de partie VI, où elle est d'un ton bleu-gris clair et très grasse et peut bientôt être sans pierres et bientôt en avoir en abondance. La première variété contient $38,8 \%$ de carbonate de chaux. L'énumération des blocs démontre, qu'aussi dans cette moraine il y a une différence entre la partie supérieure et inférieure, en ceci que le quotient de l'énumération des blocs de la partie supérieure $C_{2}$ est $0,81 \pm 0,040$, et de l'inférieure $C_{1} 0,49 \pm 0,012$. L'épaisseur peut atteindre $24 \mathrm{~m}$.

On a trouvé, in situ, dans la section $C_{1}$, du porphyre rhomboïdal et du tuf de porphyre rhomboïdal, de l'aragonite et de la pyrite; dans la section $C_{2}$, du tuf de porphyre rhomboïdal, du granite d'Åland ou bien d’Ångermanland, du porphyre de Bredvad, des calcaires siluriens, des silex tachetés, de l'aragonite et de la pyrite.

C'est au-dessus de $C_{2}$, dans parties III et VI, que l'argile à Tellina a chevauché l'argile morainique. C'est aussi $C_{2}$ que l'on voit sous le sable glacio-fluvial dans partie I.

\section{Couches glacio-fluviales $c$. Glaciofluviale Lag $\mathrm{c}$.}

On trouve, au-dessus de la moraine $C_{2}$ dans partie I, des couches de sable et de gravier glacio-fluviales, d'une épaisseur de $18 \mathrm{~m}$, qui sont régulières, horizontales, déposées en entrecroisements nettement marqués, et avec de minces couches inférieures d'argile. Elles contiennent, depuis le haut jusqu'en bas, des fragments de coquilles et des coquilles entières, dont certaines sont tertiaires, mais la plupart quaternaires, partiellement boréales et partiellement eemiennes.

Un dépôt semblable, mais beaucoup plus pauvre en fragments de coquilles et dont le volume est beaucoup moindre, apparait dans partie VII. Etant donné qu'il repose sur la moraine $C_{2}$, il doit appartenir à l'épais dépôt de sable de partie I. Les coquilles trouvées dans les couches glaciofluviales $c$, sont reportées à la page 29 .

\section{Moraine $D$.}

Moræne D.

La moraine $D$ qui est déposée pendant la poussée de glace dans le Jutland oriental et qui est la plus jeune moraine de la falaise de Rögle, apparait à la surface de partie I, comme les restes d'une argile morainique 
désagrégée, avec une épaisseur atteignant jusqu'à $2 \mathrm{~m}$. Dans les parties ouest elle est passablement grasse et rigide et contient de considérables parties d'Argile plastique étalée. On a trouvé, in situ, des granites d'Åland ou d'Ângermanland, de l'aragonite et de la pyrite. Le quotient de l'énum ration des blocs est $1,22 \pm 0,050$.

\section{La construction de la falaise de Rögle. Bygningen af Røgle Klint.}

La description suivante réfère en majeure partie aux recherches de $1913-14$.

Partie 1 . «Le profil de sable», qui est la partie la plus au sud-ouest de la falaise de Rögle, atteint une hauteur de $24 \mathrm{~m}$. La falaise est, sur une étendue de $375 \mathrm{~m}$, si nette, qu'on peut en vérifier la construction avec facilité (fig. 2, page 33). On y voit, tout en haut, les restes de la moraine $D$ désagrégée, dont l'épaisseur est de $2 \mathrm{~m}$, et sous celle-ci les couches glaciofluviales horinzontales $c$, d'une épaisseur d'environ $18 \mathrm{~m}$. Tout en bas, sur la surface de la moraine $C_{2}$ située en-dessous, se trouve une couche de pierres. Cette moraine atteint presque $4 \mathrm{~m}$ au-dessus du niveau de la mer. Elle a une surface passablement horizontale et qui, probablement, est une surface de dénudation.

Partie II. Sur l'étendue suivante, $850 \mathrm{~m}$, la falaise est couverte de végétation, mais malgré cette végétation on peut sentir que la structure de la falaise doit être la même que dans partie I (fig. 3, page 33). En bas on voit — et ceci même de loin — une terrasse qui atteint une hauteur de $5-7 \mathrm{~m}$ au-dessus du niveau de la mer. Elle apparait avec une belle végétation verte et fraiche et est certainement formée par la continuation de la moraine $C$ de partie I. Elle arrête l'eau qui s'infiltre à travers les couches glacio-fluviales $c$ situées au-dessus et la laisse ruisseler sur sa surface comme de petites sources qui continuellement arrose cette riche végétation. Des sources plus fortes, à environ $1 \mathrm{~km}$ de l'extrême point ouest de la falaise, ont même causé la formation d'une grande niche dans la falaise (fig. 4, page 33). Au-dessus de la terrasse, la végétation prend un aspect desséché et il y pousse des genêts, de la bruyère et d'autres «plantes de sable». Nous nous trouvons surement, ici, devant la continuation des couches de sable et de gravier de partie I.

Partie III est la partie de la falaise suivante. Sa longueur est de $170 \mathrm{~m}$, sa hauteur de $35 \mathrm{~m}$. Elle est éboulée et couverte d'herbe, mais nous avons pu, par différentes fouilles, dégager sa construction (fig. 5, page 37). En bas, vers le sud-ouest, se trouve la moraine $C$ qui s'élève à $27 \mathrm{~m}$ au-dessus du niveau de la mer. La surface de limite, entre celle-ci et les dépôts supérieurs, est une surface de dislocation passablement à pic, oblique et courbée. A une hauteur d'environ $16 \mathrm{~m}$ elle a sa direction vers le $\mathrm{N} 55^{\circ} \mathrm{O}$ et son inclinaison $40^{\circ}$ vers le $\mathrm{N} 35^{\circ} \mathrm{E}$; à quelques mètres plus haut, vers le $\mathrm{N} 40^{\circ} \mathrm{O}$ et l'inclinaison $30^{\circ}$ vers le $\mathrm{N} 50^{\circ} \mathrm{E}$, et encore quelques mètres plus haut, vers le $\mathrm{N} 30^{\circ} \mathrm{O}$ et $25^{\circ}$ vers le $\mathrm{N} 60^{\circ} \mathrm{E}$. Par-dessus la surface de dislocation se trouvent, tout à fait vers le sud-ouest, les couches glaciofluviales $b$, avec la couche de pierres en bas. Plus loin vers le nord-est se montre de l'argile à Tellina sous les couches glacio-fluviales $b$. Les couches ont chevauché la moraine $C$, ce qui fait que l'argile à Tellina a 
été pressée en une partie en forme de coin, qui tourne sa face aiguë en haut vers le sud-ouest. Tout à fait vers le sud-ouest, manque, comme déjà dit, l'argile à Tellina, et la moraine $C$ est couverte de sable qui continue jusque sous l'argile à Tellina pour enfin disparaître, de telle sorte que l'argile à Tellina arrive à reposer directement sur la moraine $C$. En bas, dans l'argile à Tellina, se trouvent de très minces couches de sable qui sont rompues, ce qui démontre que le bloc d'argile à Tellina a été brisé et étalé pendant son chevauchement sur la moraine $C$.

Du côté sud-ouest de la saillie en forme de nez qui forme l'épaisse partie finale de l'argile à Tellina, on trouve sur cette dernière, de minces couches d'argile et de sable qui sont fortement dérangées et courbées, de telle sorte qu'elles ont une forme de cornet (fig. 7, page 39). Il se trouve aussi une surface de dislocation entre ces couches inférieures et la série de couches supérieures, à savoir: la couche de pierres et la moraine $B$. Cette série, pendant la dislocation, a chevauché les minces couches d'argile et de sable, plus l'argile à Tellina, dans une autre direction que celle du bloc d'argile à Tellina, lorsqu'il chevaucha la moraine $C$, ce qui est constaté par les mesures suivantes. Sous la couche de pierres, et introduit par pression dans sa partie inférieure, se trouvent de minces couches d'argile étalée, qui ont facilité le mouvement. La surface de dislocation se trouvant entre - d'un côté la couche de pierres et les minces couches d'argile qui se trouvent sous elle, et de l'autre la partie la plus haute des couches de sable inférieures - prend sa direction vers le $\mathrm{N} 5^{0} \mathrm{O}$ et incline $38^{\circ}$ vers le N $85^{\circ}$ E. Plus loin vers le nord-est, de l'autre côté de la saillie en forme de nez qui est formée par le bloc d'argile à Tellina, on a mesuré que la surface de dislocation entre l'argile à Tellina et la couche de pierres avait sa direction vers le $\mathrm{N} 45^{\circ} \mathrm{E}$ et son inclinaison $20^{\circ}$ vers le $\mathrm{S} 45^{\circ} \mathrm{E}$.

La plus grande section de partie III est pour la plupart éboulée et couverte d'herbe. On peut cependant, par-dessus, y voir la moraine $B$. La couche de pierres $b$ continue en une pente descendante vers le nord-est, jusqu'à environ $8 \mathrm{~m}$ au-dessus du niveau de la mer. Là aussi on peut voir sous celle-ci les minces couches d'argile étalée.

Partie IV atteint vers le nord-est à l'endroit le plus bas de la vallée, qui, de la côte, s'en va jusqu'à la ferme Christiansminde. Cette partie qui a une longueur de $80 \mathrm{~m}$, est éboulée et couverte de végétation. Par des fouilles faites presque au milieu de cette partie (fig. 6, page 37), on a mis à jour une couche d'argile à Tellina qui arrive plus ou moìns horizontalement du sud-ouest et se courbe vers le haut en même temps qu'elle devient plus mince. Sa face inférieure se tient à environ $7 \mathrm{~m}$ au-dessus du niveau de la mer. Elle est, là où la courbe commence, d'environ 1,5 m d'épaisseur.

On trouve, par-dessus l'argile à Tellina, du sable clair avec des étalements d'argile morainique et de gravier. Sur la surface de l'argile à Tellina se trouve un certain volume de gravier, assemblé ici et là par paquet et en partie pressé dans l'argile à Tellina. Une couche de gravier avec des pierres dont la grosseur varie entre une noisette et un ouf et dont certaines sont même encore plus grandes et atteignent jusqu'à 0,7 mètre d'épaisseur, et qui se trouve à $2 \mathrm{~m}$ au-dessus de l'endroit où l'argile à Tellina se tient horizontalement et qui s'approche fortement du point où l'argile se courbe, est surement la couche de gravier $b$. Par-dessus celle-ci on peut voir des bancs alternants de sable clair, d'argile morainique et de 
gravier, répondant à la moraine $B$ de partie III. La couche de gravier située près du gros bloc d'un $1 / 2 \mathrm{~m}$ que l'on voit au milieu dans fig. 6, page 37 , a sa direction vers le $\mathrm{N} 90^{\circ} \mathrm{E}$, et son inclinaison $30^{\circ}$ vers le $\mathrm{S} 10^{\circ} \mathrm{E}$.

L'argile à Tellina forme, comme déjà dit, une courbe ayant sa convexité tournée vers l'est. Sa forme est donnée par les mesures suivantes, prises sur la face inférieure de l'argile à Tellina.

c. $8,5 \mathrm{~m}$ au dessus du niveau de la mer. Direction $\mathrm{N} 55^{\circ} \mathrm{O}$, inclinaison $76^{\circ}$, vers le $\mathrm{S} 35^{\circ} \mathrm{O}$.

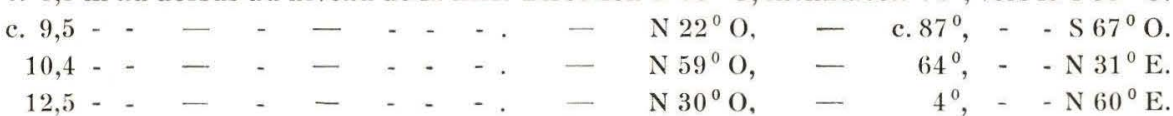

Dans la partie inférieure de l'argile à Tellina, se trouvent des paquets de sable. De minces couches d'argile se courbent vers l'est hors de la face inférieure de l'argile à Tellina et sont plus ou moins détachées d'elle. On voit, à l'est de la face inférieure, deux grandes courbes, ou bien des étalements d'argile, mélangés à des étalements de sable ou à des paquets de sable, et conforme à la face inférieure de l'argile à Tellina en ce qui concerne sa courbe. Les interstices entre les courbes sont principalement remplis de sable; cependant, ils sont, à certains endroits, si remplis de morceaux d'argile et de petits étalements, que les couches d'argile se confondent presque, et que leurs limites sont difficiles à définir.

Sous l'argile à Tellina (au N-E de celle-ci) se trouvent des couches alternantes d'argile sans pierres et de sable, et on peut voir — tout à fait au nord-est - le sable blanc $a$, en partie couleur rouille, avec de minces couches d'argile. Ces dépôts descendent très en pente et suivent la courbe de l'argile à Tellina. A la limite entre le sable blanc $a$ et les couches d'argile sans pierres et celles de sable, se trouve une étroite bande de petites concrétions ferrugineuses, serrées les unes contre les autres. La surface de limite n'est qu'une moindre dislocation qui a sa direction vers le $\mathrm{N} 45^{\circ} \mathrm{O}$ et son inclinaison $65^{\circ}$ vers le $\mathrm{N} 45^{\circ} \mathrm{E}$. Le sable blanc se trouve — tout comme les couches d'argile sans pierres et de sable — coupé au dehors vers la mer par une dislocation secondaire (une «dislocation du Petit-Belt»), qui suit à peu près le même chemin que la côte et a sa direction vers le $\mathrm{N} 70^{\circ} \mathrm{E}$ et son inclinaison $65^{\circ}$ vers le $\mathrm{N} 20^{\circ} \mathrm{O}$.

Partie $V$ a $190 \mathrm{~m}$ de longueur. Elle atteint l'endroit le plus bas de la vallée qui, de la côte, s'en va vers Christiansminde, jusqu'à une saillie peu marquée de la falaise, que nous avons nommée no. 11. Nous trouvâmes, pendant les recherches de 1913-14, les $100 \mathrm{~m}$ vers l'est si fortement éboulés et si couverts de végétation, que c'est seulement en examinant les quelques endroits dénudés et en entreprenant quelques petites fouilles, que nous pûmes nous faire une idée de la structure de la falaise. De ce fait nous constatâmes que dans la partie sud-ouest, le long du petit sentier de la vallée de Christiansminde, se présentent des dislocations secondaires (des «dislocations du Petit-Belt») ayant à peu près la même direction que la côte, et par lesquelles l'argile à Tellina s'est affaissée un peu, comparativement au sable blanc a sous-jacent, lequel, de ce fait, se trouve maintenant derrière l'argile à Tellina et complètement à l'intérieur de la falaise. Dans une de ces fouilles, à $9 \mathrm{~m}$ au-dessus du niveau de la mer et à $55 \mathrm{~m} \mathrm{~N}$-E du fond de la vallée, un mesurage de la surface de dislocation 
fut pris entre l'argile à Tellina et le sable «sous-jacent» qui se voyait dans la paroi postérieure de la fouille, sa direction était $\mathrm{N} 25^{\circ} \mathrm{E}$ et son inclinaison $80^{\circ}$ vers le $\mathrm{S} 65^{\circ} \mathrm{E}$. On ne put voir dans cette fouille, que la partie la plus basse de l'argile à Tellina, à savoir: de minces couches de sable et d'argile au ton gris-clair, qui sont coupées obliquement vers le sable par la surface de limite. Plus loin vers le sud-ouest, dans les autres fouilles faites le long du sentier déjà nommé et qui sont entreprises à $6-8 \mathrm{~m}$ au-dessus du niveau de la mer, les inclinaisons et les directions sont un peu différentes. Ici on trouve une partie plus haute de l'argile à Tellina, une argile noire plus grasse, avec des couches de sable rouge-jaune d'un ordre inférieure.

Plus loin vers le nord-est, la moitié de la partie supérieure de la falaise est formée d'argile à Tellina qui devient visible aux endroits sans végétation, ainsi que dans un éboulis assez grand. A $3 / 4$ de hauteur de la falaise on a trouvé dans de l'argile à Tellina, Tellina calcarea et Saxicava arctica.

A mi-hauteur de la falaise on fit une fouille, par laquelle le bord inférieur de l'argile à Tellina fut dégagé à environ $15 \mathrm{~m}$ au-dessus du niveau de la mer. C'était la partie basse de l'argile à Tellina, c.-a-d: de minces couches d'argile et de sable, et là-dessus du pur sable blanc $a$, dans lequel, plus au fond en bas, se trouvent de nombreuses et très minces couches d'argile. Sur la limite, entre l'argile à Tellina et le sable, une poussée a eu lieu entre les deux dépôts, lesquels sont en outre traversés de petites failles, les unes verticales, les autres obliques ou horizontales.

Dans la mi-section nord-est de partie $\mathrm{V}$, la falaise atteint sa plus haute altitude, $37 \mathrm{~m}$. Seulement par-dessus peuvent se voir quelques parois d'argile à Tellina passablement nettes, recouvertes de la couche de pierres $b$, qui est elle-même recouverte de la moraine $B$. Entre la couche de pierres et l'argile à Tellina se trouve un chevauchement (fig. 8, page 45 et fig. 14, page 59 ).

Dans l'éboulis déjà nommé, ne se trouve pour ainsi dire que de l'argile à Tellina, cependant, on voit, dans sa partie nord-est, la couche de pierres $b$, qui du milieu de l'éboulis monte jusqu'à la surface. La direction de cette couche va, de ce point, vers le $\mathrm{N} 85^{\circ} \mathrm{O}$ et son inclinaison $20^{\circ}$ vers le $\mathrm{N} 5^{\circ} \mathrm{E}$, (mesures à vue).

Plusieures fouilles furent entreprises. Dans la fouille no. 1 (fig. 9, page 45) la plus au sud-ouest, à environ $10 \mathrm{~m}$ au-dessus du niveau de la mer, on a trouvé, dans la partie inférieure, le sable blanc $a$ qui forme ici la base de la falaise. Au-dessus du sable se trouve une brèche d'environ $1 \mathrm{~m}$, qui consiste de morceaux anguleux de sable et de fin gravier et, enfin, de minces couches de sable et d'argile qui se trouvaient déjà dans la partie la plus basse de l'argile à Tellina. Au milieu de la fouille se montra une partie en forme de coin, composée de morceaux d'argile à Tellina entourés de sable et limités de chaque côté par des failles. Du côte nord-est de la fouille, la face inférieure de l'argile à Tellina prend sa direction vers le $\mathrm{N} 80^{\circ} \mathrm{O}$ et son inclinaison $25^{\circ}$ vers le $\mathrm{N} 10^{\circ} \mathrm{E}$, cependant que le côté sudouest de la fouille prend sa direction vers le $\mathrm{N} 70^{\circ} \mathrm{E}$ et son inclinaison $10^{\circ}$ vers le $\mathrm{N} 20^{\circ} \mathrm{O}$. L'argile à Tellina est donc ici poussée en avant, en rapport au sable sous-jacent, comme c'est le cas plus loin vers le sud-ouest.

Une importante fouille no. 2 fut entreprise à environ $20 \mathrm{~m}$ au-dessus du niveau de la mer. En bas on vit l'argile à Tellina avec de minces couches de sable d'ordre inférieur, traversées de crevasses de failles obliques et horizontales, remplies de sable. L'inclinaison des couches était $20-30^{\circ}$ 
vers le nord, et la direction à peu près vers l'est-ouest. Plus haut, les couches d'argile à Tellina et de sable devenaient presque de même épaisseur, $2-3 \mathrm{~cm}$, et encore plus haut, les couches de sable atteignaient une épaisseur de $6 \mathrm{~cm}$ et les couches d'argile $3 \mathrm{~cm}$; plus haut encore culminait l'épaisseur des couches de sable par une couche atteignant ses $40 \mathrm{~cm}$. Toujours plus haut apparaissait un bloc en forme de coin, rempli par une brèche consistant de morceaux d'argile et de paquets de sable agglomérés, cassés à angles vifs (fig. 10, page 49). L'autre partie se trouvait partagée par des failles, en des morceaux plus ou moins grands, dans lesquels la stratification était à peu près horizontale et non troublée. Les couches de sable, tout en haut du profil, devenaient à nouveau inférieures, et les couches d'argile grasse, dominantes.

A peu près à $160 \mathrm{~m}$ du point final S-O de la partie, trois fouilles furent entreprises, dans le haut de la falaise, à de petites distances respectives les unes des autres. On trouva, dans la fouille no. 3 la plus au nord-est, de l'argile à Tellina avec de minces couches de sable d'ordre inférieur. Un peu plus loin vers le sud-ouest, à environ $25 \mathrm{~m}$ au dessus du niveau de la mer, on fouilla un profil no. 4 , de $6 \mathrm{~m}$ de long et, dans le milieu, de $5 \mathrm{~m}$ de haut. En bas se trouvaient des couches d'argile et de sable fort peu dérangées et presque horizontales. La couche supérieure des couches de sable, qui dépassait considérablement les sous-jacentes en importance, avait $15 \mathrm{~cm}$ d'épaisseur. Au-dessus de celle-ci, la paroi était en majeure partie formée d'argile à Tellina grasse avec de très minces couches de sable. Celles-ci apparaissaient au milieu du profil comme un plissé vertical (fig. 11, page 49). Il en était de même des couches se trouvant de chaque côté, elles étaient fortement pressées et pliées. Au-dessus du plissé se trouvait un grand ensellement, formé de couches de sable et d'argiles qui étaient plus épaisses dans le dos et plus minces sur les côtés. Au-dessus de l'ensellement se trouvait de l'argile à Tellina avec des couches de sable d'un ordre extrêmement inférieur.

Encore plus loin vers le sud-ouest on fouilla un profil no. 5, de $6 \mathrm{~m}$ de long et de $2 \mathrm{~m}$ de hauteur. Il s'y trouvait, tout en haut, de l'argile à Tellina avec des couches de sable d'ordre inférieur et des coquilles de Tellina et de Saxicava. Plus bas, les couches de sable devenaient dominantes, mais tout en bas, vers le sud-ouest, c'est l'argile qui reprenait la prédominance. Au point final sud-ouest de la fouille, les couches formaient de nouveau un ensellement, et au sud-ouest de la fouille, où la paroi fut nettoyée, les couches allaient derechef en montant pour former un troisième ensellement. Dans la cuvette entre ces deux ensellements, le sable situé au-dessus est prédominant, cependant qu'au fond se voient des bancs d'argile à Tellina grasse.

Les recherches supplémentaires (par V. Nordmann). L'idée que nous nous étions faite sur la structure de la falaise dans cette partie, se confirma par des recherches supplémentaires que Nordmann et Sigurd Hansen entreprirent en 1931, et qui furent facilitées, du fait que la falaise se trouvait dénudée dans presque toute sa hauteur.

Au point final oriental de la partie d'argile à Tellina affaissée déjà nommée page 127 , un petit profil avait pris naissance, qui, tout en s'en allant uniformément jusque dans les grands profils situés plus loin vers le N-E, a pourtant une autre direction que ceux-ci. Pendant que la face de la falaise, avec ses profils, a sa direction vers le $\mathrm{N}-\mathrm{E}-\mathrm{S}-\mathrm{O}$, le petit profil 
que nous venons de nommer tourne vers le nord (fig. 12, page 51). On peut voir dans ce profil, la face inférieure de la masse d'argile à Tellina éboulé prenant sa course zigzagante et oblique vers le bas, dans la direction de l'ouest. Ce mouvement zigzagant est dû à une ligne de nombreuses failles. Il se troúve dans l'argile à Tellina, de minces couches de sable et d'argile alternantes et traversées de nombreuses failles, aussi bien horizontales que verticales, et sous celles-ci le sable blanc $a$. La limite, entre la masse d'argile à Tellina et les minces couches de sable et d'argile alternantes, a sa direction vers le $\mathrm{N} 2^{\circ} \mathrm{E}$ et son inclinaison $70^{\circ}$ vers l'E $2^{\circ} \mathrm{S}$; ceci n'est aucunement un chevauchement, mais forme une faille raide «une faille du Petit-Belt». La limite de surface prend - à peu près du milieu du profil - sa direction vers le $\mathrm{N} 4^{\circ} \mathrm{E}$ et son inclinaison $38^{\circ}$ vers le $\mathrm{N} 86^{\circ} \mathrm{O}$. La position des couches appartenant à la masse d'argile à Tellina est à peu près la même. Les couches de sable couleur rouille se trouvant dans l'argile à Tellina, ont aussi, 6,5 m plus loin du côté sudouest, leur direction vers le $\mathrm{N} 4^{\circ} \mathrm{E}$ et leur inclinaison $30^{\circ}$ vers le $\mathrm{N} 86^{\circ} \mathrm{O}$. Et encore $4,5 \mathrm{~m}$ plus loin du côté sud-ouest, les couches de sable ont leur direction vers le $\mathrm{N} 7^{\circ} \mathrm{E}$ et leur inclinaison $25^{\circ}$ vers le $\mathrm{N} 83^{\circ} \mathrm{O}$.

Les minces couches de sable et d'argile alternantes, avec les nombreuses failles et les petits chevauchements, se continuent vers le nord-est, pardessus le sable blanc $a$, qui, pour la plupart éboulé, forme la partie la plus basse de la falaise à $60-140 \mathrm{~m} \mathrm{~N}$-E du point le plus bas de la bouche de la vallée Christiansminde, à savoir: le point zéro à partir duquel on compte les mesures (fig. 13, page 53). A $50 \mathrm{~m} \mathrm{~N}$-E du point zéro, se trouve la face inférieure de l'argile à Tellina, située à environ $16,5 \mathrm{~m}$ au-dessus du niveau de la mer; $24 \mathrm{~m}$ plus loin vers le N-E elle s'affaisse jusqu'à ce que, à environ $80 \mathrm{~m}$ nord-est du point zéro, elle se trouve à $8,2 \mathrm{~m}$ au-dessus du niveau de la mer. Sur plusieurs mètres de chaque côté de cet endroit elle se montre comme une large courbe peu profonde se dirigeant vers le bas. Plus loin vers le nord-est elle se relève à nouveau. A une hauteur d'environ $14 \mathrm{~m}$ elle prend sa direction vers le $\mathrm{N} 10^{\circ} \mathrm{O}$ et incline $39^{\circ}$ vers $\mathrm{l}^{\prime} \mathrm{O} 10^{\circ} \mathrm{S}$, pendant que les couches qui se trouvent dans l'argile à Tellina prennent - elles - leur direction vers le $\mathrm{N} 14^{\circ} \mathrm{O}$ et inclinent 36 vers $l^{\prime} O 14^{\circ} \mathrm{S}$. Dès que l'inclinaison de la face inférieure, sur une étendue de $1 \frac{1}{2} \mathrm{~m}$, est devenue considérablement plus faible, de telle sorte qu'à environ $92 \mathrm{~m}$ N-E du point zéro elle se trouve à $14,7 \mathrm{~m}$ au-dessus du niveau de la mer, elle remonte précipitamment sur une étendue d'environ $1 \mathrm{~m}$, jusqu'à une hauteur de $16 \mathrm{~m}$. Cette partie montante de la face inférieure a sa direction vers le $\mathrm{N} 42^{\circ} \mathrm{O}$ et son inclinaison $58^{\circ}$ vers l'O $42^{\circ} \mathrm{S}$, pendant que les couches de l'argile à Tellina ont leur direction vers le $\mathrm{N} 30^{\circ} \mathrm{O}$ et leur inclinaison $14-16^{\circ}$ vers l'o $30^{\circ} \mathrm{S}$. Après que la face inférieure s'est tenue passablement horizontale sur un parcours d'environ $1 \frac{1}{2} \mathrm{~m}$, elle remonte à nouveau le long d'un demi mètre, jusqu'à une hauteur d'au moins $17 \mathrm{~m}$ pour, derechef, courir $2 \mathrm{~m}$ horizontalement, sur quoi elle s'affaisse de nouveau, tout d'abord en une ligne zigzagante - ceci causé par de petites failles - ensuite en une descente passablement verticale, jusqu'à environ $14 \mathrm{~m}$ au-dessus du niveau de la mer. Sa direction, à cet endroit, va vers le $\mathrm{N} 58^{\circ} \mathrm{O}$ et son inclinaison $77^{0}$ vers l'O $58^{\circ} \mathrm{S}$. Les couches de l'argile à Tellina ont leur direction vers le $\mathrm{N} 42^{\circ} \mathrm{O}$ et leur inclinaison, environ $38^{\circ}$, vers le $\mathrm{N} 48^{\circ} \mathrm{E}$.

La face inférieure continue ensuite obliquement vers le bas dans la 
direction du nord-est; à 102,5 $\mathrm{m}$ N-E du point zéro, son inclinaison et sa direction furent mesurées à $7,5 \mathrm{~m}$ au-dessus du niveau de la mer. Sa direction allait vers le $\mathrm{N} 58^{\circ} \mathrm{O}$ et son inclinaison, environ $25^{\circ}$, vers le $\mathrm{N} 32^{\circ}$ E. Elle forme de nouveau une courbe descendante, dont le point le plus bas se trouve à environ $108,5 \mathrm{~m} \mathrm{~N}$-E du point zéro, environ $6 \mathrm{~m}$ audessus du niveau de la mer. Cette courbe est encadrée par les minces couches de sable et d'argile alternantes se trouvant au-dessous, lesquelles sont si fortement traversées de failles, qu'elles prennent l'apparance d'une brèche, et leur limite contre le sable $a$ sous-jacent forme une ligne zigzagante. Leur plus importante épaisseur, $85 \mathrm{~cm}$, se trouve sous la partie la plus basse de la courbe, et elles vont en s'amincissant pendant leur montée de chaque côté de la courbe.

Dès que la face inférieure de l'argile à Tellina a atteint son plus haut point, $19 \mathrm{~m}$ au-dessus du niveau de la mer, l'argile à Tellina redescend vers le bas et atteint la côte à environ $144 \mathrm{~m}$ E-N-E du point zéro, où elle forme un éboulis en forme de nez. Sa face inférieure, à $9,3 \mathrm{~m}$ au-dessus

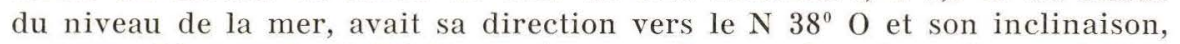
environ $40^{\circ}$, vers le $\mathrm{N} 52^{\circ} \mathrm{E}$, pendant que les couches dans l'argile à Tellina prenaient leur direction vers le N 48-60 O et inclinaient, environ $48^{\circ}$, vers le $\mathrm{N} 42-30^{\circ} \mathrm{E}$. A peu près un $1 / 2 \mathrm{~m}$ plus haut la face inférieure prenait sa direction vers le $\mathrm{N} 41^{\circ} \mathrm{O}$ et inclinait $44^{\circ}$ vers le $\mathrm{N} 49^{\circ} \mathrm{E}$.

Cette pression venant du nord-est et à laquelle la falaise de Rögle a été soumise, fut cause que la limite entre l'argile à Tellina et le sable blanc dans partie V, a subi un plissement sur une étendue d'environ $60 \mathrm{~m}$ jusqu'à $140 \mathrm{~m} \mathrm{~N}$-E de la bouche de la vallée de Christiansminde, de telle sorte qu'elle forme 3 ensellements et 2 cuvettes. L'argile à Tellina s'est facilement laissée plier, mais les couches de sable et d'argile alternantes se trouvant en-dessous ont - surtout dans les cuvettes — donné plus de résistance, ce qui eut pour résultat dans les couches de sable et d'argile, l'apparition des nombreuses failles verticales et horizontales, et même, à certains endroits de celles-ci, de formations de brèches. Le sable blanc sous-jacent montre, par les couches de gravier qu'il contient, avoir pris part au plissement.

Partie VI a $120 \mathrm{~m}$ de longueur. La falaise forme ici 2 descentes et 2 saillies en forme de nez, que nous avons pendant nos recherches nommées no. 13 et no. 17. La descente sud-ouest est limitée vers le S-O par la saillie en forme de nez no. 11, nommée plus haut, qui se trouve à l'extrémité nord-est de partie V. No. 13, le côté ouest des 2 saillies en forme de nez de partie VI est le point en relief où la côte change sa direction du S-O-N-E pour l'O-E. Le côté oriental de la saillie en forme de nez, crée la limite orientale de la partie. La hauteur de la falaise décroisse dans cette partie jusqu'à $33 \mathrm{~m}$.

Chacune des descentes, aussi bien que ia descente dans la partie suivante, est encadrée de deux parois qui se rencontrent sous un angle obtus. Celles de ces parois qui tournent vers le nord-est sont éboulés, pendant que celles qui tournent vers le nord-ouest ont gardé leur partie supérieure plus ou moins nette. On peut observer, ici, les différents dépôts qui ont été déposés les uns sur les autres et voir que tous inclinent à peu près dans la direction nord-est. Les descentes ont été produites par éboulement, ceci causé par l'eau souterraine qui filtre par-dessus des couches d'argile, où elle se trouve arrêtée. 
Dans la paroi qui tourne vers le N-O dans la descente ouest qui est située entre no. 11 et no. 13 (fig. 15, page 59), on voit, en bas, la partie la plus haute de l'argile à Tellina, dont la partie inférieure, ainsi que le sable $a$ sous-jacent, sont cachés par des masses éboulées. L'argile à Tellina, ici, est la continuation vers l'est, de cette argile à Tellina décrite dans partie V, et dans la section sud-ouest de laquelle elle monte à la surface de la falaise. Au-dessus de l'argile à Tellina, mais séparée d'elle par une dislocation, se trouve la couche de pierres $b$, qui est une continuation de la couche de pierres de partie $\mathrm{V}$ où elle monte à la surface. Beaucoup des pierres de cette couche atteignent une importante grandeur, jusqu'à $0,7 \mathrm{~m}$. Elles sont, pour la plupart, cimentées emsemble en un conglomérat brun, produit par une sécrétion de fer. D'importants blocs conglomérés atteignant jusqu'à $2 \mathrm{~m}$ de longueur ont été précipités sur la côte, là où la couche l'atteint presque (fig. 14, page 59).

La paroi située directement au-dessus de la couche de pierres se trouve en partie éboulée, étant donné qu'elle est composée de sable et d'argile morainique appartenant à la moraine $B$. Au-dessus de l'éboulis, là où la paroi se trouve nette et propre, on peut voir la partie supérieure de cette moraine, consistant d'argile gris-brun et maigre, recouverte de nouveau par la moraine $C$, laquelle a, ici, $5 \mathrm{~m}$ d'épaisseur et se compose d'argile morainique grîs-bleu. La limite entre les deux moraines, qui n'est pas très nette, est marquée principalement par la différence des couleurs. Il est facile, par les énumérations des blocs, de tenir les deux moraines séparées l'une de l'autre. Les deux premiers mètres du haut de la falaise sont formés d'une argile sableuse et fortement effritée, à savoir: la moraine discordante $D$.

Dans la descente à l'est, entre les saillies en forme de nez no. 13 et no. 17; on peut voir les moraines $B$ et $C$ qui se continuent dans une petite paroi qui, du milieu de la descente, monte vers le haut, au-dessus des masses de terre éboulés. Dans la paroi qui tourne vers le nord-ouest (fig. 16, page 63 ), se trouve, en bas, la moraine $C$, qui est d'un ton gris-bleu clair et très grasse par endroits. Par-dessus la moraine $C$ on voit, vers le nord-est, l'argile à Tellina qui du milieu de la paroi se projette en l'air en forme de coin, de telle sorte que les dépôts qui se trouvaient sur elle se trouvent maintenant reposer directement sur la moraine C. L'argile à Tellina ne s'est cependant pas déposée normalement sur la moraine $C$, mais est passée par-dessus elle, de sorte que la limite est une surface de chevauchement. On mesura, à $18 \mathrm{~m}$ au-dessus du niveau de la mer, que sa direction allait vers le $\mathrm{N} 57^{\circ} \mathrm{O}$ et son inclinaison $40^{\circ}$ vers le $\mathrm{N} 33^{\circ} \mathrm{E}$; $1,7 \mathrm{~m}$ plus haut et $2,5 \mathrm{~m}$ plus loin dans la paroi, la direction allait vers le $\mathrm{N} 70^{\circ} \mathrm{O}$ et l'inclinaison $30^{\circ}$ vers le $\mathrm{N} 20^{\circ} \mathrm{E} ; 2 \mathrm{~m}$ encore plus haut et $3,7 \mathrm{~m}$ encore plus loin à l'intérieur, vers le $\mathrm{N} 40^{\circ} \mathrm{O}$ et $25^{\circ}$ vers le $50^{\circ} \mathrm{E}$; et tout près où l'argile à Tellina ressort en forme de coin, vers le $\mathrm{N} 54^{\circ} \mathrm{O}$ et $35^{\circ}$ vers le $\mathrm{N} 36^{\circ}$ E. La surface de chevauchement se trouve ainsi être oblique et courbée, et son inclinaison est relativement grande tout près de l'endroit où l'argile à Tellina ressort en forme de coin, ensuite elle décroisse rapidement pour de nouveau s'amplifier dans sa descente vers le nord-est, tout comme la surface de chevauchement de partie III, qui lui est similaire.

L'argile à Tellina est noire, passablement maigre et contient, surtout vers le bas, une bonne quantité de minces couches de sable qui, près de la 
surface de chevauchement, sont recourbées, ce qui fait qu'elles trainent sur celle-ci (fig. 17, page 63). L'argile à Tellina est assez grasse dans sa partie supérieure et ne contient pas de sable. L'argile à Tellina, qui audessus vers le sud-ouest ressort en forme de coin, donne l'aspect au profil d'avoir une petite queue, ceci parce que le coin va en montant. Ce fait, conjointement avec d'autres conditions qui seront mentionnées aussitôt, démontre que la surface de l'argile à Tellina est aussi une surface de chevauchement, et que les dépôts se trouvant maintenant au-dessus ont été poussés sur l'argile à Tellina et la moraine $C$.

Par-dessus l'argile à Tellina on voit, sur de petites étendues, du gravier avec de grosses pierres, qui sont les restes de la couche de pierres $b$. La surface de chevauchement entre l'argile à Tellina et le gravier, a sa direction vers le $\mathrm{N} 80^{\circ} \mathrm{O}$ et son inclinasion $30^{\circ}$ vers le $\mathrm{N} 10^{\circ} \mathrm{E}$. Des restes de gravier semblables se retrouvent directement sur la moraine $C$, où l'argile à Tellina a disparue.

La moraine $B$ repose sur l'argile à Tellina et sur les restes du gravier, et par-dessus celle-ci se trouve la moraine discordante $D$.

Partie VII a $65 \mathrm{~m}$ de longueur. La hauteur de la falaise décroît jusqu'à $30 \mathrm{~m}$. La partie forme une descente délimitée par deux saillies en forme de nez, no. 17 et no. 20 (fig 18, page 67). La paroi qui tourne vers N-O et l'arrière-plan de la descente se tiennent passablement nets et propres. On voit ici, tout en bas de l'argile à Tellina, la continuation de celle-ci dans la descente précédente. Au-dessus de l'argile à Tellina se trouvent tout d'abord des bancs d'argile maigre sans pierres, et de sable, par-dessus ceux-ci la moraine $B$, et sur cette dernière la moraine $C$.

Les moraines $B$ et $C$ se trouvant dans la paroi tournée vers le nord-ouest sont faciles à distinguer l'une de l'autre, en ceci que la moraine $B$ consiste de bancs d'argile morainique gris-brun, maigre, riche en pierres, et avec des couches de sable d'ordre inférieur, pendant que la moraine $C$ est bleugris; mais par-dessus, du côté de l'arrière plan de la descente, elle est rouge.

Sur la moraine $C$ et en partie dans un creux de celle-ci, reposent des couches stratifiées de sable blanc $c$ grenu, à angles aigus, et avec des morceaux de coquilles. Au-dessus de ce sable se voit la moraine discordante $D$ qui, dans le fond de la descente, se continue par-dessus la moraine $C$.

Si l'on considère comme une seule, les trois parties V, VI et VII, on peut remarquer que deux fois dans celles-ci on rencontre la même série de couches, c.-a-d: (en commençant par le bas), l'argile à Tellina, la couche de pierres $b$, la moraine $B$ et la moraine $C$. Le sable blanc $a$ - couche sousjacente de l'argile à Tellina - est signalé dans les parties IV, V et VII. Les deux rangs de couches sont séparés par un chevauchement qui est localisé dans partie VI. Par suite de la position oblique des couches, chaque dépôt monte à deux endroits jusqu'à la moraine discordante $D$, une fois dans chaque rang de couches, à l'exception cependant de la couche de pierres qui, dans le rang de couches oriental, se trouve être très abimée.

Partie VIII a $60 \mathrm{~m}$ de longueur. La falaise s'affaisse à cet endroit, jusqu'à une hauteur de $17 \mathrm{~m}$. Om trouve ici un ravin broussailleux qui se continue dans la campagne et jusque dans le jardin de la ferme Sölyst (fig. 19, page 67). La falaise est, soit en action d'éboulement, soit éboulée, à l'exception toutefois d'une petite paroi de l'arrière plan vers l'ouest. On peut voir, dans celle-ci, la moraine discordante $D$, avec ses étalements caractéristiques 
d'Argile plastique, qui reposent sur de l'argile morainique bleue, à savoir: la moraine $C$.

La saillie en forme de nez no. 21, qui délimite la descente vers l'est, est composée de moraine $C$, qui cependant ne forme pas, ici, une continuation directe de la moraine $C$ du fond et de partie VII, en ceci qu'elle prend presque une position verticale avec la surface vers l'ouest. On retrouve aussi à cet endroit, au-dessus dans la falaise, la moraine discordante $D$.

Comme cela ressort par ce qui suit, il doit se trouver peut-être, dans cette descente, une dislocation, de chaque côté de laquelle, dans la falaise, apparait la même série de couches n'ayant qu'une minime différence dans son développement, mais avec les couches, par contre, s'en allant dans un ordre de succession contraire.

Partie IX a $130 \mathrm{~m}$ de longueur. Elle commence à la saillie en forme de nez no. 21, et va jusqu'au «ravin d'Argile micacée». La falaise se soulève uniformément jusqu'à une hauteur de $28 \mathrm{~m}$ dans la section la plus à l'est de la partie. La paroi de la falaise est spécialement nette et propre dans sa partie supérieure et jusqu'en bas sur les saillies, ce qui permet de voir clairement que les couches se tiennent presque verticales dans cette partie, et comme déjà cité plus haut, dans un ordre de succession contraire à celui que l'on trouve dans les autres parties plus loin vers l'ouest. C'est pourquoi nous jugeons plus pratique de commencer par la description de cette partie à l'est (fig. 20, page 71).

A l'arrière du «ravin d'Argile micacée», on voit, vers l'est, l'Argile plastique, et vers l'ouest la moraine $A$. La limite entre ces deux dernières est la dislocation de limite du horst d'Argile plastique (fig. 22, page 71). En 1913 on mesura dans la partie ouest du ravin, et on vit que la dislocation de limite avait sa direction vers le $\mathrm{N} 30^{\circ} \mathrm{O}$ et son inclinaison $70^{\circ}$ vers le S $60^{\circ}$ O. Il se montra, par les travaux de révision de 1915, que des éboulis avaient pris place, de telle sorte que l'endroit où les mesures avaient été prises ne put être retrouvé. Par contre, il fut possible de prendre une mesure de la dislocation de limite, un peu plus loin et un peu plus bas dans le ravin. Elle avait sa direction vers le $\mathrm{N} 50^{\circ} \mathrm{O}$ et son inclinaison $45^{\circ}$ vers le $\mathrm{N} 40^{\circ} \mathrm{E}$.

Un peu plus loin vers la mer, la moraine $A$ se trouve en partie recouverte par de minces couches alternantes de Sable micacé noir-brun ou verdâtre clair, qui ont leur direction vers le N $50-60^{\circ} \mathrm{O}$, en partie par de l'Argile micacée sableuse noire, et en partie par des couches noduleuses brunes, contenant de la glauconie avec du gypse cristallin et des petits grains noirs. Plus loin vers la bouche du ravin, la couche noduleuse contient des coquilles brisées et mal conservées. La succession des couches va comme suit: la couche noduleuse (se trouvant tout à fait à l'extérieur de la paroi) est la plus ancienne, puis vient l'Argile micacée. Le Sable micacé (le plus à l'intérieur contre la moraine) est le plus jeune. Toutes ces couches sont soulevées de can, étalées et traversées de failles. Ce qui reste de ces couches varie en épaisseur depuis 0 jusqu'à un petit nombre de mètres.

Afin de procéder à l'examen de la limite entre le tertiaire et la moraine $A$ dans la partie situé tout à fait à l'extérieur du ravin, nous entreprîmes en 1915 une fouille dans le côté ouest de ce ravin, et nous atteignîmes une faille presque horizontale, avec une poussée de la partie supérieure, de $25 \mathrm{~cm}$ dans la direction de l'ouest. Par-dessus la faille on trouve - le plus à l'ouest - la moraine $A$, dont la surface de limite orientale avait 
sa direction vers le $\mathrm{N} 25^{\circ} \mathrm{O}$ et son inclinaison $65^{\circ}$ vers le $\mathrm{S} 65^{\circ} \mathrm{O}$. L'argile morainique se rencontrait avec celle-ci jusqu'à une masse de sable blanc qui vers le bas devenait plus large, jusqu’à $70 \mathrm{~cm}$. Entre la faille et le sable se trouvait du gravier dont l'épaisseur augmentait vers l'ouest de 0 à $16 \mathrm{~cm}$. Il y avait, dans le gravier, des roches cristallines et du silex. Le côté oriental du sable blanc était couvert de quelques centimètres d'Argile micacée noire et qui de nouveau se limitait à l'Argile plastique. La surface de limite entre celle-ci et l'Argile micacée, était une surface de dislocation courbe, dont la direction allait vers le $\mathrm{N} 20^{\circ} \mathrm{O}$ et dont l'inclinaison descendait uniforme jusqu'en bas, de $50^{\circ}$ à $70^{\circ}$, vers le $\mathrm{N}$ $70^{\circ}$ E. Sous la faille horizontale déjà nommée, se trouvait aussi - le plus à l'ouest - l'argile morainique dont la surface de limite orientale inclinait, ici, $65^{\circ}$ vers le $\mathrm{N} 65^{\circ}$ E. A l'est de cette dernière se trouvait environ $20 \mathrm{~cm}$ de sable blanc recouvert d'Argile micacée, et sur celle-ci l'Argile plastique. La surface de dislocation, entre cette Argile et l'Argile micacée, avait sa direction — à cet endroit — vers le $N 25^{\circ}$ O et son inclinaison $50^{\circ}$ vers le $\mathrm{N} 65^{\circ} \mathrm{E}$.

Les mesures prises démontrent que pendant que la direction de la dislocation de limite du horst d'Argile plastique ne varie que de $30^{\circ}$, entre le $\mathrm{N} 20^{\circ} \mathrm{O}$ et $\mathrm{N} 50^{\circ} \mathrm{O}$, l'inclinaison varie non seulement dans sa grandeur de $45^{\circ}$ à $70^{\circ}$, mais aussi dans sa direction de $\mathrm{S} 60^{\circ} \mathrm{O}$ à $\mathrm{N} 70^{\circ} \mathrm{E}$. La surface de dislocation est donc une surface oblique et courbe.

Sur le côté ouest du ravin on pouvait, en 1912, en bas de la falaise vers la côte, observer l'Argile micacée qui était séparée de la moraine $A$ par une mince couche verticale de Sable micacé qui avait sa direction vers le $\mathrm{N} 35^{\circ} \mathrm{O}$. A présent on ne voit plus que la moraine $A$ qui se tient verticale et a une épaisseur de $5-6 \mathrm{~m}$; elle est composée d'argile moranique noir-brun avec de nombreux étalements de sable.

Entre la moraine $A$ et les couches glacio-fluviales $a$, se trouve une zone de sable d'une épaisseur de $70 \mathrm{~cm}$ avec de minces striures d'argile morainique. La direction de la couche de la zone varie entre $\mathrm{N} 28-34^{\circ} \mathrm{O}$.

Si l'on continue le long de la côte, on voit les couches glacio-fluviales a apparaître dans la falaise, sur une longueur d'environ $20 \mathrm{~m}$; tout d'abord des couches de sable verticales jaunes ou brunes, avec des morceaux de vase de lignite et d'Argile micacée, «des pierres roulées» d'argile morainique et quelques pierres. La direction est $\mathrm{N} 20-45^{\circ} \mathrm{O}$. A l'ouest de ces couches se trouvent des couches de sable blanc avec du mica, et contenant des couches d'argile grise sans pierres, d'ordre inférieur. Ces couches appartiennent aussi au dépôt $a$.

A l'ouest de ce dépôt, là où la falaise est nette et propre, on voit les couches glacio-fluviales $b$; premièrement des couches alternantes de sable et d'argile, puis une couche de gravier avec des pierres de la grosseur d'une tête d'enfant et même plus grosses, là-dessus encore d'autres couches alternantes de sable et d'argile, ainsi que quelques couches de gravier. Ces couches contiennent aussi des morceaux noirs et certaines en sont pleines, on y trouve aussi des pierres éparses. Ensuite viennent des couches d'un gravier mal assorti; les plus anciennes (celles situées le plus à l'est) contiennent encore des morceaux noirs. On trouva, dans l'une des couches de gravier, des pierres de la grosseur d'une tête, et même plus grandes et atteignant jusqu'à un demi-mètre. L'épaisseur assemblée des couches glacio-fluviales $b$ est d'environ $11 \mathrm{~m}$. Leur direction variait entre N 34 
$50^{\circ}$ O. Toutes les couches se tenaient pour ainsi dire verticales. Ce sont ces couches qui, si souvent, ont été décrites et illustrées par Forchнамmer. C'est d'ailleurs pourquoi elles sont appelées «couches de Forchhammer (fig. 21, page 71). Elles sont, dans le haut, nettement coupées par la moraine discordante $D$, qui a ici $1 \mathrm{~m}$ d'épaisseur.

Par des fouilles entreprises dans la partie supérieure de la falaise - là où à l'est des couches de ForchHammer elle se trouve recouverte de masses de terre éboulées - nous eûmes la chance de pouvoir démontrer qu'ici aussi, entre les couches glacio-fluviales $a$ et $b$, se trouve un morceau d'argile à Tellina (fig. 23 et 24 , page 79 ). Il descend de plus en plus en pointe jusqu'à $14,5 \mathrm{~m}$ au-dessus du niveau de la mer et on peut le suivre dans sa montée jusqu'à environ $19 \mathrm{~m}$ au-dessus du niveau de la mer. A $18 \mathrm{~m}$ id., son épaisseur est de $1,3 \mathrm{~m}$. La direction et l'inclinaison du morceau furent mesurées à différentes hauteurs, d'abord la face supérieure (côté ouest) puis la face inférieure (côté est). Les deux faces sont des dislocations obliques et courbes. La face supérieure avait sa direction variant entre $\mathrm{N} 30-50^{\circ} \mathrm{O}$ et son inclinaison entre $40-82^{\circ}$ vers le $\mathrm{N} 40-60^{\circ} \mathrm{E}$, pendant

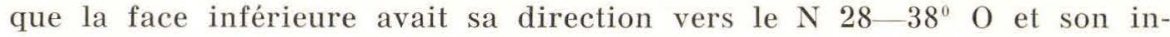
clinaison $65-87^{\circ}$ vers le S $52-62^{\circ} \mathrm{O}$. Une des couches du morceau d'argile à Tellina, qui était riche en mica et qui se trouvait à peu près au milieu du morceau, avait sa direction vers le $\mathrm{N} 30^{\circ} \mathrm{O}$ et son inclinaison $86^{\circ}$ vers le $\mathrm{S} 66^{\circ} \mathrm{O}$. La face inférieure est done presque parallèle avec les couches du morceau. Les couches glacio-fluviales $b$ arrivent tout contre la face supérieure (côté ouest) du morceau d'argile à Tellina, en des angles pointus. Le rebord entre la face supérieure et la face inférieure se continue vers le bas. On le voit dans la paroi de la falaise, comme une dislocation entre les couches glacio-fluviales $a$ et $b$, c-à-d dans la partie la plus basse de la falaise, où l'argile à Tellina manque. Il avait, à $9 \mathrm{~m}$ au dessus du niveau de la mer, sa direction vers le $\mathrm{N} 35^{\circ} \mathrm{O}$ et son inclinaison $72^{\circ}$ vers le $\mathrm{N}$ $55^{\circ}$ E. Les couches glacio-fluviales $a$, les plus à l'ouest, ont, au lieu de leur position primaire, pris une position courbe sur une étendue de quelques mètres - ceci dû au mouvement du morceau d'argile à Tellina — de sorte qu'elles arrivent presque horizontalement vers le côté oriental du morceau et se traine vers le bas avec lui et en se tenant tout contre lui.

Si l'on continue sa route vers l'est le long de la falaise, on rencontre la moraine $B$, dont l'épaisseur peut être jugée comme étant d'environ $23 \mathrm{~m}$. Il $\mathrm{y}$ a cependant une transition très uniforme entre les couches glaciofluviales $b$ et la moraine $B$, en ceci que la partie la plus basse de cette moraine est composée de bancs verticaux alternants d'argile morainique, de couches de sable et d'étalements de sable. La partie inférieure de cette moraine est remarquable en son tout à cause de sa disposition par bancs. Quelques-uns des bancs sont noir-brunâtre et formés, manifestement et principalement, d'Argile micacée. D'autres sont bleu-noirâtre et plus normaux. La moraine $B$ s'en va sans limite coupante dans la moraine $C$, qui forme la terminaison de partie IX vers l'ouest. Ces moraines sont, en haut dans la falaise, coupées par la moraine discordante $D$.

Aperçu (par V. Nordmann). Parties I et II montrent trois dépôts quaternaires non troublés, à savoir: tout en bas la moraine $C$, par-dessus celle-ci le sable glacio-fluvial $c$ avec des fragments de coquilles de mollusques aussi bien tertiaires que quaternaires, se trouvant en lit secondaire, et par là-dessus la moraine $D$. Les surfaces de limites entre les trois 
dépôts sont horizontales; seule la section sud-ouest de partie I se tient passablement nette et propre. Les parties III-IX sont les parties de la falaise dans lesquelles l'argile à Tellina apparait. Dans partie III elle se montre comme une masse dont la surface s'affaise uniformément vers le nord-est. La face inférieure s'affaisse dans la même direction mais un peu plus à pic, de telle sorte que la masse prend en épaisseur en descendant vers la côte, cependant qu'elle monte vers le sud-ouest, en forme de coin. La masse vers le sud-ouest est poussée par-dessus la moraine $C$, qui forme la continuation de la section la plus basse dans les parties II et I. On voit, au-dessus de la masse d'argile à Tellina dans partie III, de minces couches de sable et d'argile, la couche de sable et de pierres $b$, et la moraine $B$. La surface de limite, entre la couche de pierres et les minces couches de sable et d'argile, est une surface de chevauchement oblique.

Dans partie IV, directement du côté sud-ouest de la vallée de Christiansminde, on a constaté, par des fouilles, que l'argile à Tellina qui dans la partie précédente s'affaissait obliquement vers le nord-est, après s'être tenue horizontalement sur une certaine étendue, se soulève à présent, et monte en une courbe vers le rebord de la falaise, dont la convexité tourne vers le bas du côté de la côte dans la direction nord-est. Les couches se trouvant par-dessus le sable $b$ et la moraine $B$, prennent part au mouvement de courbe. L'argile à Tellina n'est, dans eet embranchement ascensionnel, que d'une épaisseur d'environ $1 \frac{1}{2} \mathrm{~m}$; mais on voit, sur sa face inférieure (côté est), des étalements d'argile sans pierres plus minces et aux formes courbes, qui sont surement la partie inférieure et détachée de l'argile à Tellina; sous ceci (vers l'est) on voit le sable $a$.

Dans partie V, du côté opposé de la vallée, on voit l'argile à Tellina tout en haut de la falaise, prendre fortement en épaisseur vers l'est et reposer sur la sable $a$. Cependant on ne voit pas sa véritable épaisseur, car sa stratification démontre qu'elle incline en-dehors de la falaise, ce qui fait que le profil n'arrive pas à se tenir vertical sur les couches; ceci est dû en partie à une compression de l'argile à Tellina par une poussée de côté, ce qui est évident par les couches de l'argile à Tellina qui se montrent courbées et pliées, (à l'un des endroits comme un plissé vertical), ainsi que par la face inférieure de l'argile à Tellina, qui laisse voir deux courbes descendantes. La limite, entre l'argile à Tellina et le sable blanc $a$ sous-jacent, laisse voir ainsi trois ensellements et deux cuvettes. Il n'y a aucun doute que cette partie d'argile à Tellina ait été en contact avec l'argile à Tellina de partie IV, par un ensellement qui a disparu lorsque la vallée de Christiansminde fut formée plus tard par érosion. Directement du côté nord-est de cette vallée, on voit une partie d'argile à Tellina se tenant en relief au pied de la falaise. Les minces couches de sable jaunerougeâtre se trouvant dans l'argile, montrent des courbes tournées vers le bas, (pour l'inclinaison et la direction, voir page 130). Cette partie a un profil orienté vers le nord, ce qui démontre que l'argile à Tellina à l'intérieur de la falaise - se limite contre le sable $a$, cela prouve aussi que la partie a glissé vers le bas le long d'une faille, «faille du Petit-Belt», parallèle en tout et pour tout avec la falaise. L'argile à Tellina et le sable sous-jacent a sont traversés de nombreuses failles, en partie horizontales ou obliques, mais principalement verticales, qui ont causé un déplacement, de sorte que le bord inférieure de l'argile à Tellina avance en une ligne 
zigzagante. Le même cas se reproduit autour des parties inférieures des courbes déjà mentionnées, qui sont formées par la surface inférieure de l'argile à Tellina, située dans la mi-partie supérieure de la falaise.

La surface de l'argile à Tellina stationnaire, s'affaisse vers l'est en une descente courbe dans la direction de la côte et est recouverte de sable $b$ et de la couche de pierres, ainsi que de la moraine $B$, qui est elle-même recouverte de la moraine $C$. On voit, en haut de la falaise, ces moraines ressortant en forme de coin, dans la direction de l'ouest, ceci causé par l'érosion qui a emporté la partie la plus haute de la falaise pendant la poussée en avant de la glace, qui a déposé la moraine discordante $D$.

Dans partie VI on voit une nouvelle masse d'argile à Tellina reposant sur la moraine $C$, située à l'ouest; cette masse d'argile à Tellina s'en va en montant - passablement pointu — vers le rebord de la falaise, dans la direction de l'ouest. La limite, entre l'argile à Tellina et la moraine $C$ sous-jacente, est une surface de dislocation, ceci nullement dû à une simple rupture perpendiculaire dans la série de couches, qui aurait comme suite le chevauchement de la partie orientale sur celle de l'ouest, mais dû bien certainement, à ce que la série — en un rapport similaire avec les conditions de partie $\mathrm{V}$ - a été recourbée en un grand pli qui s'est brisé dans son point supérieur, et dont la partie descendante a disparu par le mouvement de la dislocation, de sorte que celle-ci n'est plus visible audessus de l'eau. Sur cette argile à Tellina reposent — tout comme sur la précédente - le sable et la couche de pierres $b$, la moraine $B$ (qui est ici peu épaisse), puis la moraine $C$, et le tout est recouvert de la moraine discordante $D$. Ainsi que se courbe l'argile à Tellina vers l'est cependant qu'elle descend vers la côte, ainsi se courbent aussi en descendant vers la côte, les parties déjà mentionnées du sable $b$, de la couche de pierres et des moraines $B$ et $C$; ce qui peut se voir dans partie VII. On sait d'ailleurs que ces parties ont aussi pris part au pliement. En haut de partie VII on voit - pressée en profondeur dans la surface de $C$ - une partie en forme de lentille, faite de sable $c$ avec des fragments de coquilles de mollusques roulées, tertiaires et quaternaires, répondant tout à fait au sable $c$ se trouvant par-dessus la moraine $C$ dans partie I.

Partie VIII comprend les deux sections de la moraine $C$, qui se trouvent chacune d'un côté du grand éboulis qui va jusque dans le jardin de la ferme Sölyst. Ces deux masses de moraine doivent être considérées, comme appartenant (chacune liée à sa propre branche) à un très grand pli descendant, (voir l'esquisse fig. 25, page 85). En haut de l'éboulis qui se trouve entre les deux masses de moraine, on voit, dans la paroi du fond, la moraine $D$ dont l'épaisseur est plus importante que d'habitude; elle contient des morceaux et des étalements d'Argile plastique.

Dans partie IX on voit des parties de couches formant la branche orientale du grand pli déjà mentionné, à savoir: (de l'ouest à l'est), la partie inférieure de la moraine $C$, la moraine $B$, le sable $b$ avec la couche de gravier lui appartenant et qui dans cette partie de la falaise est surnommée «les couches de Forchinamer», l'argile à Tellina (seulement représentée par le petit morceau triangulaire en haut de la falaise), la couche de sable $a$ et la moraine $A$. C'est le seul endroit dans toute la falaise où cette moraine est visible. C'est aussi bien à cause de l'importante épaisseur de la série de couches dans cette partie - suivant toute apparence $140 \mathrm{~m}$ - que parce que ces couches se tiennent toutes sans 
exception dans une position verticale, que l'on juge comme fort probable que ce pli (1er pli dans le profil schématique, fig. 25) s'en va jusqu'à une importante profondeur sous le niveau de la mer.

Sur la face inférieure de la moraine $A$ (vers l'est), se trouve une mince couche de Sable micacé oligocène, avec un petit nombre de fossiles mal conservés.

Le «ravin d'Argile micacée» sépare la série de couches quaternaires de la partie d'Argile plastique poussée en hauteur et située à l'est. Dans la paroi arrière du fond du ravin on voit, entre cette Argile et la moraine $A$, la limite dont la position est pour ainsi dire verticale. Les deux formations sont recouvertes de la moraine discordante $D$.

Il n'y a aucun doute que le soulèvement de la grande partie d'Argile plastique que l'on voit entre Stavrhoved à l'est et les couches quaternaires de la falaise de Rögle à l'ouest, ne soit la cause des dérangements et des pliages dans la série de couches quaternaires, primordialement horizontales. Les formations quaternaires, qui tout d'abord se tenaient par-dessus l'Argile plastique, ont été en partie, plus tard, abaissées par pression, en trois grands ravins dans la partie supérieure de cette Argile, (c.-à-d à la pointe orientale et occidentale du bois de Kassemose Skov et à environ $700 \mathrm{~m}$ E-N-E de la ferme Sölyst), et en partie emportées par le glacier qui a laissé derrière lui la moraine discordante $D$ et a aussi enlevé par érosion le haut des couches quaternaires repliées, dans les parties IX--V.

On ne peut dire avec certitude ce qui a suscité le soulèvement de l'Argile plastique; mais d'après les raisons qui sont données à la page 120 , nous sommes de l'opinion que cela n'est aucunement dû - soit directement ou indirectement - à la nappe de glace, mais par contre à des forces tectoniques.

\section{Remarques finales.}

Slutningsbemærkninger.

Par Victor Madsen.

Ce n'est pas sans hésitation que nous publions cette monographie de la falaise de Rögle, car, jusqu'à présent, malgré tous nos efforts, nous n'avons pas réussi à interpréter à souhait tous les phénomènes compliqués qui distinguent cette falaise.

Par une suite de recherches et d'études, continués depuis nombre d'années, et dont nous avons rendu compte précédemment, nous sommes arrivés enfin — pensons-nous - à trouver la solution définitive de la question la plus inextricable de la falaise, à savoir: la cause de ses dislocations. Nous en avons déduit que c'est le soulèvement du horst de l'Argile plastique, situé au N-E de la falaise, et la pression due à ce soulèvement qui a causé le rétrécissement de la falaise, lequel a eu pour conséquence, les plis et les chevauchements qui s'y trouvent.

Ayant le sentiment qu'il ne nous est pas possible, avec les moyens dont nous disposons, d'aller plus loin; nous avons maintenant décidé de publier notre ouvrage, quoiqu'il reste encore à faire des analyses mécaniques, chimiques et pétrographiques des différents dépôts de la falaise, ainsi que des déterminaisons des grains minéraux de ses moraines, et surtout à examiner — par des recherches géophysiques — s'il y a un horst de sel à l'intérieur du horst d'Argile plastique, et de tirer au clair si les chevauchements sont des chevauchements de blocs ou si ce sont des plis obliques, 
étirés jusqu'à la suppression complète de leurs flancs laminés. Nous considérons la dernière alternative comme la plus probable, étant donné que les inclinaisons des surfaces de chevauchement ne sont que de 20 à $40^{\circ}$.

Selon notre hypothèse, les parties disloquées de la falaise de Rögle, parties IX-III, consistent de 4 synclinaux importants et de 3 anticlinaux intermédiaires.

En longeant la falaise de l'est, nous croisons, entre le «ravin d'Argile micacée» et le «ravin de Sölyst», tout d'abord le flanc oriental (gauche) perpendiculaire du premier s y clin al (1er pli de fig. 25, page 85). Il existe, dans ce flanc, entre les couches glacio-fluviales $a$ et $b$, une dislocation dans laquelle l'argile à Tellina a été presque tout à fait élimée, de sorte qu'il n'en reste qu'un petit morceau en haut dans la falaise. A l'ouest du «ravin de Sölyst» nous rencontrons le flanc occidental oblique du premier synclinal, dans lequel l'argile à Tellina est bien conservée. C'est une question s'il existe en tout une dislocation dans le «ravin de Sölyst», ou si ce ravin n'est pas plutôt tout simplement formé par érosion le long du plan axial du synclinal.

Le flanc occidental du premier synclinal devient, vers l'ouest, le flanc oriental du premier anticlinal déversé, dont le flanc occidental est élimé dans le chevauchement de partie VI.

A l'ouest du chevauchement (sous celui-ci) se trouve le flanc occidental du de uxi ème s y n clinal (2me pli de fig. 25) dont le flanc oriental a été élimé dans le chevauchement.

Le flanc occidental du deuxième synclinal se continue en haut dans le flanc oriental du de uxi ème anticlinal qui s'étend par-dessus la «vallée de Christiansminde», dans partie IV. La surface entre l'argile à Tellina et le sable glacio-fluvial $a$ sous-jacent, est pliée en 3 anticlinaux secondaires et 2 synclinaux secondaires intermédiaires ( 3 me et 4 me plis de fig. 25).

Le flanc occidental du deuxième anticlinal se continue en bas dans le flanc oriental du $\mathrm{t} \mathrm{r}$ o i s i è $\mathrm{me} \mathrm{s} \mathrm{y} \mathrm{n} \mathrm{clina} \mathrm{l}$, dans partie IV, ( $5 \mathrm{me}$ pli de fig. 25), dont le flanc occidental devient le flanc oriental du troisi è $\mathrm{me}$ a n ti c lin a l. Le flanc oriental de cet anticlinal déversé, est élimé dans le chevauchement de partie III.

A l'ouest de ce chevauchement (sous celui-ci) nous trouvons le flanc occidental du quat $\mathrm{ri}$ è $\mathrm{me} \mathrm{s} \mathrm{yn} \mathrm{clinal}$, car son flanc oriental a été élimé dans le chevauchement. Le dit flanc occidental qui - à part ce que l'on voit de la moraine $C$ dans partie III - est abaissé sous la surface de la mer, se continue, supposons-nous, dans les couches horizontales des parties II et I.

Voilà notre conviction de la construction de la falaise de Rögle, à laquelle nous sommes arrivés par nos recherches et nos études de tant d'années.

\section{Les directions \\ et les inclinaisons des dislocations et des couches. Dislokationernes og Lagenes Strygninger og Hældninger.}

Dans ce chapitre sont assemblées les directions et les inclinaisons des dislocations et des couches qui sont mesurées dans la falaise de Rögle.

Si l'on fait abstraction des «failles du Petit-Belt», qui n'ont pris naissance qu'après les dérangements des couches de la falaise de Rögle et n'ont par 
conséquent rien à voir avec ceux-ci, les 72 mesures prises des directions et des couches, se tiennent entre $\mathrm{N} 5^{\circ} \mathrm{O}$ et $\mathrm{N} 85^{\circ} \mathrm{O}$, à l'exception cependant de 3 , qui ont leurs directions vers le $\mathrm{N} 45^{\circ} \mathrm{E}$, le $\mathrm{N} 70^{\circ} \mathrm{E}$ et le $\mathrm{N} 80^{\circ} \mathrm{E}$. Si l'on omet ces 3 , ainsi que les couches de sable $a$ très en pente de partie IX (page 90) qui ont leur direction vers le $\mathrm{N} 20-45^{\circ} \mathrm{O}$, on obtient comme moyenne des 29 directions des dislocations, $\mathrm{N} 42^{\circ} \mathrm{O}$, et comme moyenne des 39 directions des couches, aussi $\mathrm{N} 42^{\circ} \mathrm{O}$. On peut d'après ceci conclure que la force de la poussée qui fut causée par le soulèvement du horst, a eu sa direction du $\mathrm{N} 48^{\circ} \mathrm{E}$ vers le $\mathrm{S} 48^{\circ} \mathrm{O}$.

\section{Enumérations des blocs. \\ Stentællinger.}

Pendant les recherches faites dans la falaise de Rögle, 116 échantillons des différentes sortes de moraines de la falaise furent pris, afin de pouvoir, avec ceux-ci, entreprendre les énumérations des blocs. (Pour la méthode employée, voir: Aperçu de la Geologie de Danemark. Danmarks geologiske Undersøgelse. V. Række. Nr. 4, page 95, à partir de la 10 me ligne en bas, jusqu'à la 6 me ligne en haut de page 96 ).

Les résultats de ces énumérations de blocs, sont donnés dans les tables pages $96-103$, dans lesquelles figurent: le poids des blocs en grammes, le nombre des blocs, le pourcentage de roches cristallines, de grès siliceux, de grès plus friable, de schistes, de calcaires paléozoïques, de calcaires crétaciques, de silex, de roches tertiaires, d'espèces différentes et incertaines, le pourcentage de roches cristallines dans la somme de silex et de roches cristallines, le pourcentage de calcaires paléozoïques dans la somme de silex et de calcaires paléozoïques, ainsi que le nombre des silex, divisée avec le nombre des roches cristallines (le quotient de l'énumération des blocs).

Les quotients des énumérations des blocs des différentes moraines ont donné les moyennes suivantes.

\begin{tabular}{|c|c|c|c|c|c|}
\hline Moraine & A. 8 & énumérations & des & blocs & $0,36 \pm 0,044$ \\
\hline$\gg$ & $B_{1} .7$ & $\gg$ & $\gg$ & $\gg$ & $0,50 \mp 0,049$ \\
\hline$\gg$ & $B_{2} \cdot 30$ & $\gg$ & $\gg$ & $\gg$ & $0,82 \mp 0,026$ \\
\hline$\gg$ & $C_{1} \cdot 18$ & $\gg$ & $\gg$ & $\gg$ & $0,49 \pm 0,012$ \\
\hline$\gg$ & $C_{2} \cdot 43$ & $\gg$ & $\gg$ & $\gg$ & $0,81 \mp 0,040$ \\
\hline$\gg$ & $D \cdot 7$ & $\gg$ & $\gg$ & $\gg$ & $1,22 \mp 0,050$ \\
\hline
\end{tabular}

Si l'on compare la moyenne des quotients des énumérations des blocs dans la moraine $D$ de la falaise de Rögle, avec la moyenne des 15 quotients des énumérations des bloes dans la moraine $D$ de la falaise de Ristinge à Langeland, $1,20+0,119$, on voit que la concordance est très grande. La différence entre elles est moindre que l'erreur moyenne. Les énumérations des blocs faites en Fionie (Fyn), démontrent que la moraine $D$ prend tout le nord et la partie centrale de Fionie (Fyn), à l'intérieur du partage des eaux entre les rivières qui s'en vont jusqu'au Kattegat et au Odense Fjord, et celles qui s'en vont jusqu'au Grand et Petit Belt. Le quotient de l'énumération des blocs de la moraine $D$ en Fionie, est $1,29 \pm 0,032$ (116 déterminations). 
Entre la moraine $C$ de la falaise de Ristinge, dont le quotient de l'énumération des blocs est $0,68+0,064$ ( 15 déterminations), et la moraine $C_{2}$ de la falaise de Rögle, dont le quotient de l'énumération des blocs est $0,81 \pm 0,040$, la concordance est moins grande. La concordance est plus grande entre cette moraine et la moraine $C$ dans le Jutland méridional, à l'intérieur de la région où la moraine de surface doit être considérée comme étant la moraine $C$, et dont les 57 énumérations des blocs ont donné $0,88+047$, pendant que les 23 énnumérations des blocs sur la carte Bække dans les parages où la moraine supérieure doit être considérée comme étant la moraine $C$, ont donné $0,82 \pm 0,056$.

Entre la moraine $B_{2}$ de la falaise de Rögle dont le quotient de l'énumération des blocs est $0,82 \pm 0,026$, et les moraines de surface $B$ de la deuxième époque glaciaire sur les cartes Varde et Bække à l'ouest du Jutland, dont le quotient de l'énumération des blocs est 0,84 $\pm 0,057$ (32 déterminations), la concordance est aussi très grande.

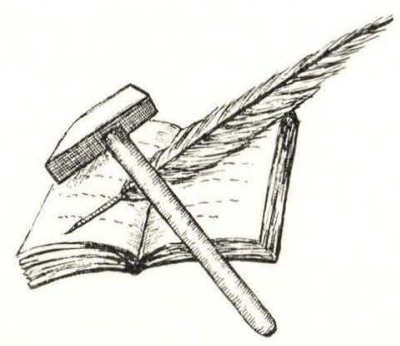




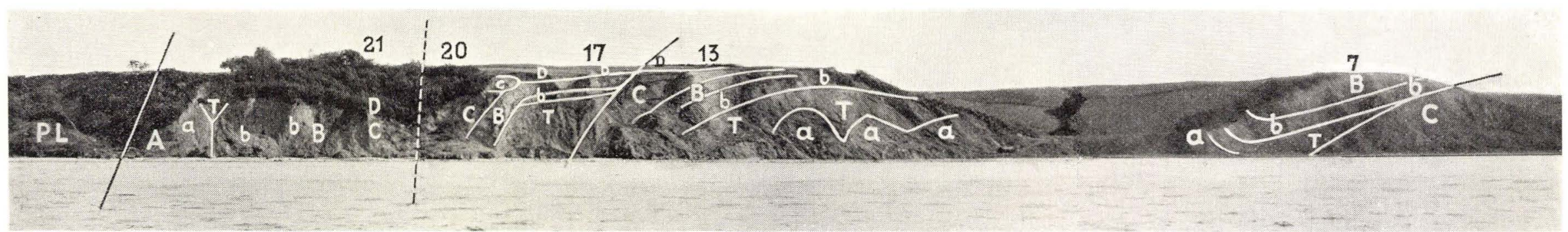

Fig. 27.

Parties IX - III de la falaise de Rögle lorsqu'on les regarde de la mer. Tout à fait à gauche on voit un peu du horst d'Argile plastique qui, dans «le ravin d’Argile micacée», est limité par une cassure. La force qui souleva le horst fut si violente, que les dépôts quaternaires d'à côté furent eux-mêmes soulevés en l'air et prirent, de ce fait, une position verticale. C'est pourquoi l'on rencontre, à l'ouest du ravin, une série de couches verticales, à savoir: la moraine $A$, les couches de sable et de gravier $a$, puis trés haut dans la falaise, le reste d'un morceau d'argile à Tellina $T$, les couches de sable et de gravier $b$, et enfin la moraine $C$, le tout recouvert d'une façon discordante par la moraine $D$ tout à fait en haut de la falaise. Ensuite arrive «le ravin de Sölyst», dans lequel il y a peut-être une cassure qui limite les couches verticales vers l'ouest. On rencontre maintenant les couches dans un ordre contraire; premièrement: (dans la saillie en forme de nez 20), la moraine $C$, par-dessus laquelle ont voit, en haut de la falaise, le sable $c$ avec des coquilles de mollusques, et tout en haut la moraine discordante $D$. Sous la moraine $C$ se trouvent la moraine $B$, les couches de sable et de gravier $b$ et l'argile à Tellina $T$. Cette série a été, par pression pendant le soulèvement du horst, poussée par-dessus la moraine $C$ (dans la saillie en forme de nez 17.). Sous la moraine $C$ on retrouve de nouveau la moraine $B$, les couches de sable et de gravier $b$ et l'argile à Tellina $T$, qui; plus loin vers l'ouest, ont été pliées en 3 anticlinaux, intercalés de 2 synclinaux. Ici, en bas de la falaise, on voit le sable $a$ qui avance sous l'argile à Tellina. On est à présent arrivé à la vallée dans laquelle un chemin va jusqu'à Christiansminde. Il doit y avoir eu ici, jadis, au moins un anticlinal qui, maintenant, a disparu par érosion, car il existe, au sud-ouest de la vallée, un peu du flanc ouest d'un anticlinal, dans lequel se trouve le sable $a$, l'argile à Tellina $T$, les couches de sable et de gravier $b$ et la moraine $B$. Ensuite ces couches se courbent en hauteur et ont été dans la saillie en forme de nez 7, poussés par-dessus la moraine $C$. On trouve done, dans les parties à l'ouest du "ravin de Sölyst», un chevauchement, une étendue pliée, puis de nouveau un chevauchement.

Partierne IX-III i Røgle Klint, set ude fra Havet. Helt til Venstre ses lidt af Plastisk Ler-Horsten, der i »Glimmerlerkloften « er begrænset af et Brud. Den Kraft, som loftede Horsten, var saa voldsom, at under Horstens Bevægelse opad førtes Kvartæraflejringerne ved Siden af den med i Vejret og kom i lodret Stilling. Vest for Kloften møder man derfor en Række lodrette Lag: Moræne A, Sand- og Gruslagene a, højt oppe i Klinten Resten af en Tellinalerflage T, Sand- og Gruslagene b og Moræne C, overlejrede diskordant af Moræne D øverst i Klinten. Saa kommer "Sølystkløften", i hvilken der maaske er et Brud, som begrænser de lodrette Lag mod Vest. Derefter moder man Lagene i omvendt Orden, først (i Næse 20) Moræne C, over hvilken man foroven i Klinten ser Sandet med Molluskskaller c og øverst den diskordante Moræne D. Under Moræne C ligger Moræne B, Sand- og Gruslagene b og Tellinaleret T. Denne Serie er ved Trykket under Horstens Hævning bleven skudt op over Moræne C (i Næse 17). Under Moræne C træffer man nu atter Moræne B, Sand- og Gruslagene b og Tellinaleret $\mathrm{T}$, som videre mod Vest er blevet foldet i 3 Antiklinaler med to mellemliggende Synklinaler. Her kommer forneden i Klinten Sandet a frem under Tellinaleret. Man er nu naaet til Dalen, i hvilken en Vej gaar op til Christiansminde. Her maa der forhen have været mindst een Antiklinal, som nu er borteroderet, for SV. for Dalen findes der lidt af den vestlige Fløj af en Antiklinal, i hvilken man træffer Sandet a, Tellinaleret T, Sand- og Gruslagene b og Moræne B. Disse Lag bøjer sig derefter opad og er i Næse 7 skudt op over Moræne C. I Partierne- Vest for "Sølystkløften findes der saaledes en Overskydning, en foldet Strækning og atter en Overskydning. 
